\title{
High-Performance Group Transfer Catalysis by Copper Complex with Redox-Active Ligand in an Entatic State
}

Yufeng Ren, Jeremy Forte, Khaled Cheaib, Nicolas Vanthuyne, Louis Fensterbank, Hervé Vezin, Maylis Orio, Sébastien Blanchard, Marine DESAGE-EL MURR

Submitted date: 19/07/2019 - Posted date: 22/07/2019

Licence: CC BY-NC-ND 4.0

Citation information: Ren, Yufeng; Forte, Jeremy; Cheaib, Khaled; Vanthuyne, Nicolas; Fensterbank, Louis; Vezin, Hervé; et al. (2019): High-Performance Group Transfer Catalysis by Copper Complex with Redox-Active Ligand in an Entatic State. ChemRxiv. Preprint.

Metalloenzymes use earth--abundant non--noble metals to performhigh-fidelity transformations in the biological world. To ensure chemical efficiency, metalloenzymes have acquired evolutionary reactivity--enhancing tools. Among these, the entatic state model states that a strong steric entatic state, strongly improving the reactivity. However, while the original definition refers both to the transfer of electrons or chemical groups, the chemical application of this concept in synthetic systems has mostly focused on electron transfer, therefore eluding chemical transformations. Here we report that a highly-strained redox--active ligand enables a cooper complex to perform catalytic nitrogen-- and carbon---group transfer in as fast as two minutes, thus exhibiting a strong increase in reactivity compared to its unstrained analogue. This is the first report combining two reactivity---enhancing features from metalloenzymes, entasis and redox cofactors, applied to group--transfer catalysis.

File list (2)

article-final-Chemrxiv.pdf (4.92 MiB)

view on ChemRxiv - download file

SI-paper-final.pdf (17.25 MiB)

view on ChemRxiv - download file 


\title{
High-performance group transfer catalysis by copper complex with redox-active ligand in an entatic state
}

\author{
Y. Ren, ${ }^{1}$ J. Forté, ${ }^{1}$ K. Cheaib, ${ }^{1}$ N. Vanthuyne, ${ }^{2}$ L. Fensterbank, ${ }^{1}$ H. Vezin, ${ }^{3}$ M. Orio, ${ }^{2}$ S. Blanchard,${ }^{1}$ and M. Desage- \\ El Murr ${ }^{4} *$ \\ ${ }^{1}$ Sorbonne Université, Institut Parisien de Chimie Moléculaire, UMR CNRS 8232, 75005 Paris, France \\ ${ }^{2}$ Aix Marseille Université, CNRS, Centrale Marseille, iSm2, UMR CNRS 7313, 13397 Marseille, France \\ ${ }^{3}$ Université de Lille 1, LASIR, UMR CNRS 8516, 59655 Villeneuve d'Ascq Cedex, France \\ ${ }^{4}$ Université de Strasbourg, Institut de Chimie, UMR CNRS 7177, 67000 Strasbourg, France \\ *e-mail: desageelmurr@unistra.fr
}

Metalloenzymes use earth-abundant non-noble metals to perform high-fidelity transformations in the biological world. To ensure chemical efficiency, metalloenzymes have acquired evolutionary reactivity-enhancing tools. Among these, the entatic state model states that a strong steric distortion induced by ligands around a metal center gives rise to an energized structure called entatic state, strongly improving the reactivity. However, while the original definition refers both to the transfer of electrons or chemical groups, the chemical application of this concept in synthetic systems has mostly focused on electron transfer, therefore eluding chemical transformations. Here we report that a highly-strained redox-active ligand enables a copper complex to perform catalytic nitrogen- and carbon-group transfer in as fast as two minutes, thus exhibiting a strong increase in reactivity compared to its unstrained analogue. This is the first report combining two reactivity-enhancing features from metalloenzymes, entasis and redox cofactors, applied to group-transfer catalysis.

The biological world offers potential clues to solve the current pressing energy and resources-related issues. ${ }^{1,2}$ The efficiency of biological catalytic systems faces chemists with the challenges of transferring enzymatic performance into synthetic small-molecule catalysts using non noble metals. Metalloenzymes use earth-abundant $3 d$ metals and amino acid-derived coordination spheres to achieve complex (multi)electronic transformations required for small-molecule activation and atom transfer reactions. To fulfil these stringent criteria of natural resources, metalloenzymes have evolved reactivity-enhancing strategies aimed at performing such difficult transformations through more favourable thermodynamic pathways. The entatic state concept stems from the observation that single molecule coordination complexes designed as metalloenzymes models often fail to exhibit properties similar to the natural metalloenzymatic active sites. ${ }^{3-6}$ It was thus suggested that secondary and tertiary structures induced by amino acid-based side chains in proteins provide distortions in the coordinative environment that endow the metal center with enhanced reactivity, to which Vallée and Williams refer as "a catalytically poised state". ${ }^{3}$ Strikingly, a strong link between local geometric frustration induced by tertiary structure effects around enzymatic catalytic sites and their catalytic activity has recently been unveiled. ${ }^{7}$ Frustration patterns were demonstrated to be evolutionary highly conserved, more than the primary structure or residues forming the catalytic site itself, which establishes the central relevance of coordinative distortion to enzymatic catalytic activity.

Entasis is well-known in copper proteins involved in electron transfer such as blue copper proteins and has traditionally been studied in the context of $\mathrm{Cu}^{\prime} / \mathrm{Cu}^{\prime \prime}$ oxidation states. When tetracoordinated, these two oxidation states have distinct geometric requirements from tetrahedral to square planar, and the entatic state exhibits an in-between distorted geometry that minimizes energetic penalties arising from coordinative reorganization (Fig. 1a). Possible designs for coordination spheres inducing ligand misfit have been discussed by Comba. ${ }^{8}$ The majority of reports involve two ditopic or one cyclic tetradentate ligands and include systems with biphenyl subunits, ${ }^{9}$ multiple bonds and rigid or substituted structures, carbohydrate backbones ${ }^{10}$ and guanidinoquinoline ligands. ${ }^{11,12}$ More recently, 
the entatic state concept was extended to photoinduced electronic transfers ${ }^{13}$ thus showing the continued relevance of this biomimetic feature in electron transfer chemistry. While most studies focus on electron transfer involving a $\mathrm{Cu}^{\prime} / \mathrm{Cu}^{\prime \prime}$ redox couple, the seminal article by Vallée and Williams ${ }^{3}$ states that entatic behavior arising from ligand misfit also extends to enzymatic metallic sites performing "transfer of an atom, radical, or a group", as well as higher metallic oxidation states such as $\mathrm{Co} / \mathrm{Co}^{\prime \prime \prime}$ in corrin enzymes and $\mathrm{Fe} / \mathrm{Fe}{ }^{\prime \prime \prime} .{ }^{14} \mathrm{~A}$ recent report on the hydroxylation of methane to methanol by heterogeneous catalysis performed by iron-containing zeolithes demonstrates that the zeolithe lattice induces a matrix strain which activates a square planar $\mathrm{Fe}(\mathrm{II})$ site into a $\mathrm{Fe}(\mathrm{IV})=0$ reactive center through entasis, ${ }^{15}$ and a bispidine $\mathrm{Fe}(\mathrm{IV})=0$ species in an entatic state has been reported to perform oxygen-group transfer in homogeneous catalysis. ${ }^{16}$ These examples of oxygengroup transfer systems, which emulate natural systems' catalytic arsenal, provide great opportunities for the design of synthetic systems able to perform highly-desired transformations such as multielectronic small-molecule activation. However, to date, no synthetic catalytic system was demonstrated to perform group-transfer other than oxygen through the entatic state model.

Just as the entatic state principle provides a fruitful trail of inspiration for coordination chemists, other biomimetic strategies, related to electron transfer, focus on enzymatic redox co-factors that provide electrons to the active sites. ${ }^{17,18}$ Such systems are known as redox-active ligands. This field of research is morphing into an area of intense development aimed at harnessing the potential of systems with rich redox flexibility. ${ }^{19-28}$ Recently, an entatic pair of copper complexes bearing redoxactive guanidine ligands was shown to enable fine-tuning between metal- and ligand-based electronic transfers. ${ }^{29}$ This structural study was the first report interfacing the two concepts of entasis and redox-active ligands, and was focused on the electronic behavior of the entatic pair. Using redox-active copper complex $\mathrm{Cu}(\mathrm{SQ})_{2}$ ( $\mathrm{SQ}$ : iminosemiquinone) originally developed as a Galactose Oxidase (GAO) model, ${ }^{30,31}$ we have shown that ligand-based redox activity influences the overall reactivity of the complex towards electron transfer, ${ }^{32,33} \mathrm{C}-\mathrm{N}$ bond formation ${ }^{34}$ and nitrogen group transfer ${ }^{35}$ while preserving a $\mathrm{Cu}(\mathrm{II})$ oxidation state. Here we report a novel acyclic tetradentate redox-active ligand exhibiting $C_{2}$ symmetry with overall three possible rotations around single bonds (degrees of freedom). This particular geometry induces enhanced catalytic reactivity of resulting complex 1 through entasis. This specific ligand design combines an atropisomeric backbone, which enforces chirality and exerts an outward strain, with a redox-active iminosemiquinone/iminobenzoquinone ONNO coordination sphere which pulls in the opposite inward direction towards metal chelation (Fig. 1b). These conflicting steric demands induce a coordination stress while the bridging binaphtalene backbone installs full conjugation between the two redox-active units, resulting in enhanced electronic delocalization. Complex 1 performs catalytic nitrogen and carbon group transfer in as fast as two minutes on a model substrate, and exhibits up to a forty-fold increase in synthetic efficiency compared to its unstrained analogue $\mathrm{Cu}(\mathrm{SQ})_{2}$. Moreover, it can convert sterically hindered or unactivated alkenes. The present work shows that interfacing two reactivity-enhancing features from metalloenzymes, such as entasis and redox cofactors, enables fast and high-yielding group-transfer catalysis. 
a
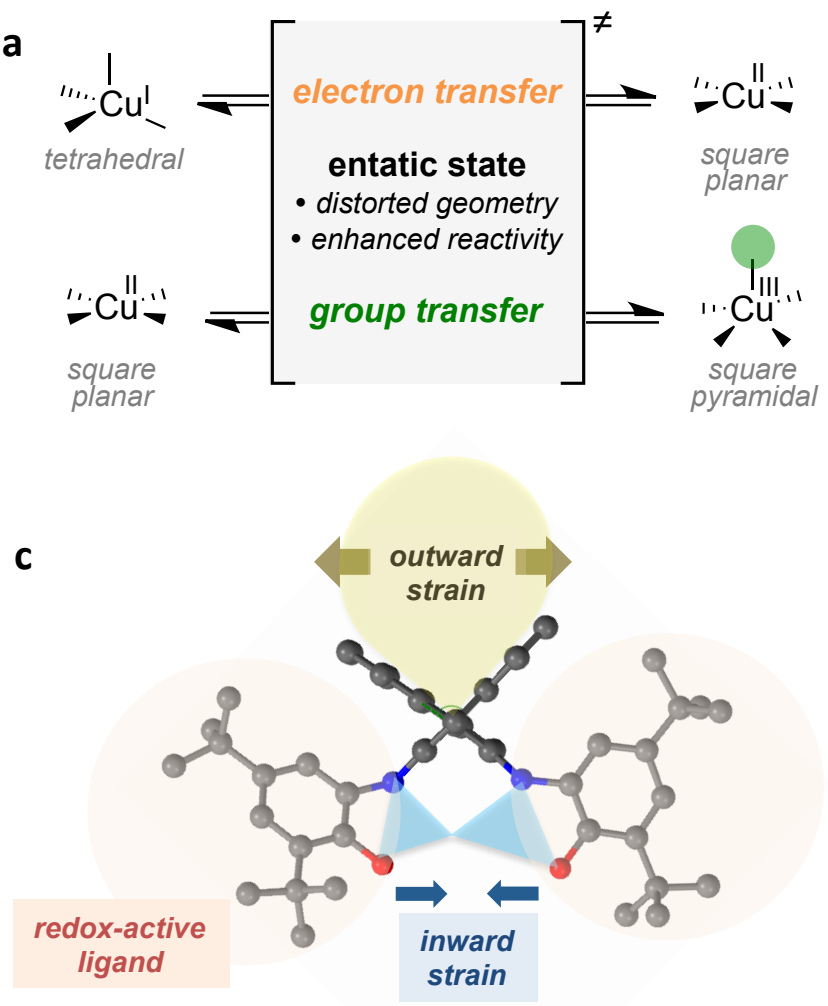

b

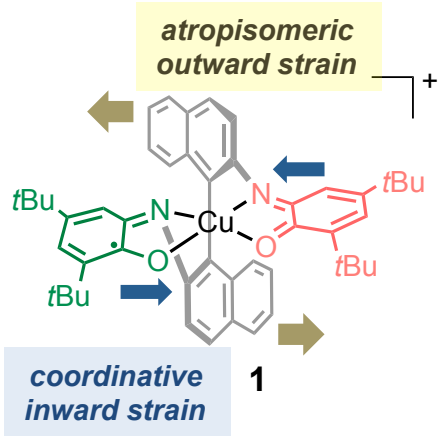

d

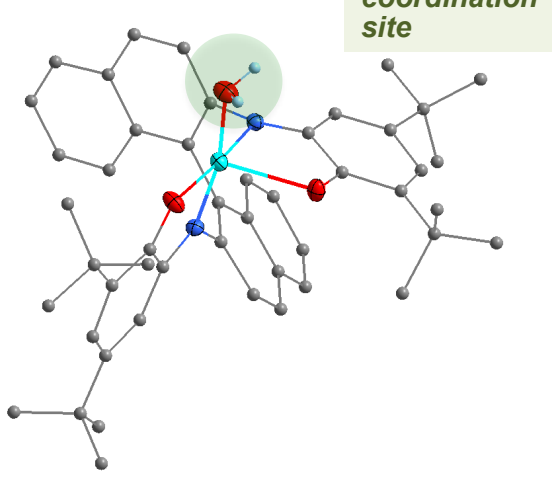

Figure 1. Design of a new redox-active ligand creating a vacant coordination site at metal through strong coordination distortion. a, The entatic state reactivity model for electron and group transfer in a tetracoordinated copper complex. b, Structure of complex $\mathbf{1}$ [CuBINap (SQ-BQ)] ${ }^{+}$. c, X-ray crystal structure of ligand $\mathbf{2}$ representing the associated strains. $d, X$-ray crystal structure of complex $\mathbf{1}$ exhibiting a pentacoordinated coordination sphere resulting from coordination strain.

\section{Results}

Complex synthesis and structural studies. Condensation of two tert-butylcatechol with 1,1'binaphthyl-2,2'-diamine yields easy access to 1,1'-binaphtyl-2,2'-diaminophenol (hereafter noted BINap) ligand (Figure 2a and $\mathrm{SI}$ ), and its structure was confirmed by X-ray crystallography (Fig. 1c). Aerobic complexation of BINap ligand $\mathbf{2}$ with copper chloride affords complex $\mathrm{Cu}\left(\mathrm{BINap}-\mathrm{SQ}_{2}\right) \mathbf{3}$ as a green solid. The spectroscopic signature of $\mathbf{3}$ is very similar to those of $\mathrm{Cu}(\mathrm{SQ})_{2} \mathbf{4}$ (Fig. $2 \mathrm{~b}$ ) and $\mathrm{Cu}\left(\mathrm{L}_{\mathrm{Biphen}} \mathrm{SQ}_{2}\right)$, a copper complex reported by Chaudhuri and incorporating a biphenyl unit instead of the atropisomeric binaphthyl unit. ${ }^{36}$ At $10 \mathrm{~K}, 3$ displays a $\mathrm{S}=1 / 2$ signal centered on the copper (Fig. SI6), as attested by the strong anisotropy of the EPR spectrum and the presence of hyperfine coupling with the $I=3 / 2$ copper nucleus. The doublet ground spin state of $\mathbf{3}$ is further supported by DFT calculations (Supplementary Table S15). The UV-vis spectrum of $\mathbf{3}$ (Fig. 2d) presents the expected ligand to ligand (SQ to SQ) charge transfer band around $900 \mathrm{~nm}(800 \mathrm{~nm}$ in 4 and $880 \mathrm{~nm}$ in $\left.\mathrm{Cu}\left(\mathrm{L}_{\text {Biphen }} \mathrm{SQ}_{2}\right)\right)$ which points towards 3 as a $\mathrm{Cu}(\mathrm{II})$ complex bearing a dianionic diradical $\mathrm{BINapSQ}_{2}$ ligand. This description is in agreement with the DFT-calculated electronic structure of $\mathbf{3}$ (Fig. SI-2829). The cyclic voltammogram of $\mathbf{3}$ displays four reversible waves (two oxidative and two reductive, Supplementary Fig. SI-5) at redox potentials very close to those of the parent complexes, indicating similar electronic structures and ligand-based redox processes (Supplementary Tables S1-2).

Oxidation of $\mathrm{Cu}\left(\mathrm{BINap}-\mathrm{SO}_{2}\right) 3$ with $\mathrm{Br}_{2}$ followed by halide abstraction led to the formation of fully oxidized $\left[\mathrm{Cu}\left(\mathrm{BINap}-\mathrm{BQ}_{2}\right)\right]^{2+} \mathbf{5}$. The singly oxidized complex [Cu(BINap-SQ-BQ)$]^{+} 1$ can be prepared either by oxidation of $\mathbf{3}$ with 1 equiv. $\mathrm{AgPF}_{6}$ or by mediamutation between an equimolar mixture of 
complexes $\mathbf{3}$ and $\mathbf{5}$ (see $\mathrm{SI}$ ). Cyclic voltammograms of $\mathbf{1}$ and $\mathbf{5}$ are very similar to that of $\mathbf{3}$ and only differ by the onset potential, thus attesting the chemical reversibility of the redox processes. While 1 is X-band EPR silent at $10 \mathrm{~K}, \mathbf{5}$ displays an EPR spectrum in agreement with an $\mathrm{S}=1 / 2$ ground state centered on the copper (Fig. SI-9). The doublet ground spin state of $\mathbf{5}$ has been also predicted by DFT calculations (Fig. SI-33,34). The UV-vis spectrum of 1 displays around $1200 \mathrm{~nm}$ a LLCT band associated with the oxidation of a SQ moiety into BQ, whereas no LLCT can be identified for fully oxidized 5 (Fig. 2d). This is reminiscent of the parent complexes and confirms that the two oxidation processes are ligand-centered. Enantiopure R or $\mathbf{S}$ complexes of $\mathbf{1}$ and $\mathbf{3}$ can be synthesized from enantiopure R or S forms of 2, as attested by circular dichroism and chiral HPLC analysis (Fig. SI-3-4).

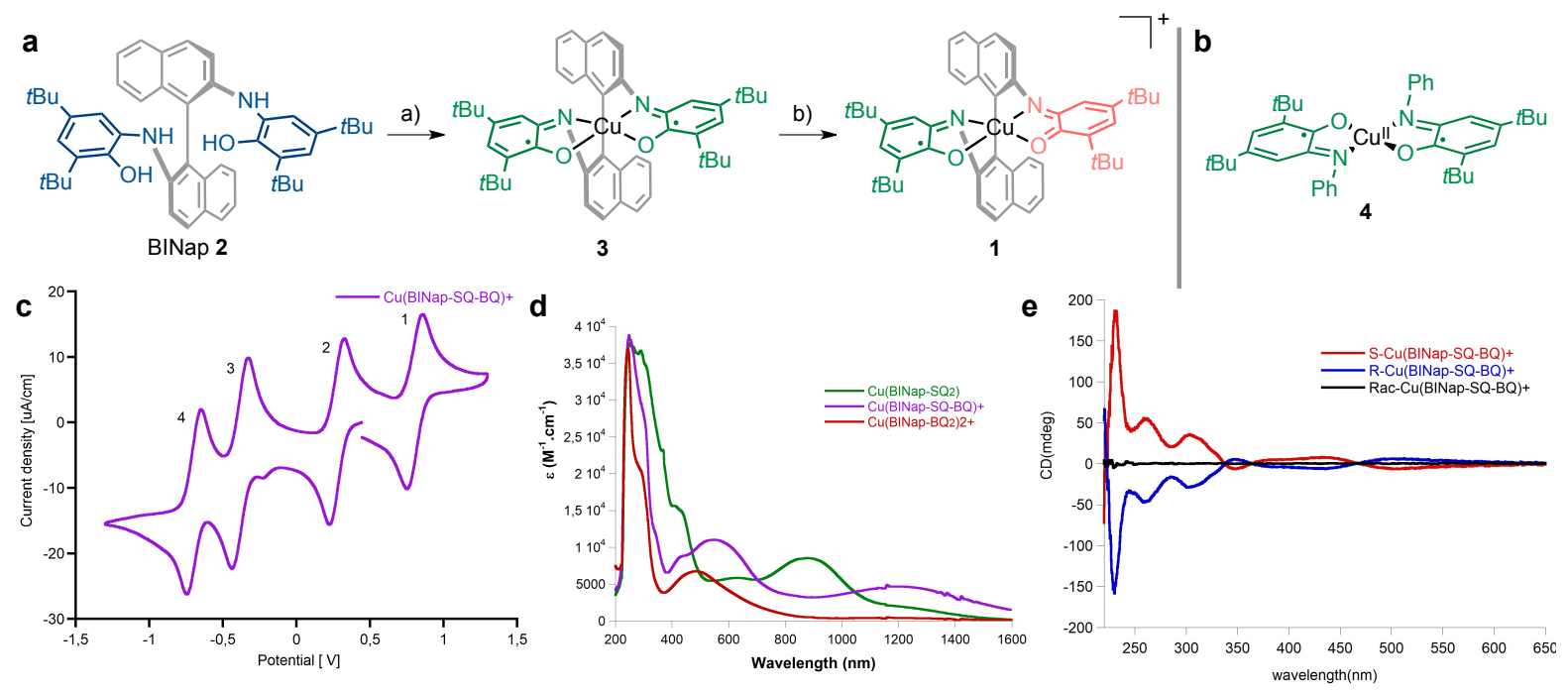

Figure 2. a, Synthetic scheme for complex 1, reaction conditions: a) $\mathrm{CuCl}$ (1 equiv.), $\mathrm{Et}_{3} \mathrm{~N}$ (4 equiv.), dry acetonitrile; b) AgOTf (1 equiv.). b, Unstrained complex $\mathrm{Cu}(\mathrm{SQ})_{2} 4$. c, Cyclic voltammogram of complex 1. d, UV-vis-NIR spectrum of [Cu(BINap-SQ-BQ)] 1 (purple), Cu(BINap-SQ 2 ) 3 (green) and $\left[\mathrm{Cu}\left(\mathrm{BINap}-\mathrm{BQ}_{2}\right)\right]^{2+} 5$ (see $\mathrm{SI}$ for structure, red); $0.1 \mathrm{mM}$ in DCM at rt. e, Circular dichroism spectrum of racemate and enantiopure $[\mathrm{Cu}(\mathrm{BINap}-\mathrm{SQ}-\mathrm{BQ})]^{+} \mathbf{1}(\mathrm{C}=0.3 \mathrm{mM})$.

Attempts to grow crystals of $\mathbf{3}$ led to very weakly diffracting samples, with maximum resolution of $1.29 \AA$ (see $\mathrm{SI}$ ) which indicate that the copper center is in coordinence $4\left(\mathrm{~N}_{2} \mathrm{O}_{2}\right.$ of BINap). Crystals suitable for $\mathrm{X}$-ray diffraction were obtained on racemate and enantiopure samples of complex $\mathbf{1}$ and revealed that the coordination sphere is completed by an aquo ligand to provide a square pyramidal environment in which an oxygen atom of the BINap occupies the axial position, and not the water molecule ${ }^{37}$ (Fig. 1d). This unusual coordination sphere can be explained by the coordination stress resulting from the design of ligand $\mathbf{2}$, and the singly oxidized SQ-BQ redox-active subunit, which bears increased electrophilicity compared to complex 3 . The combination of these unique steric and electronic features induces a distorted pentacoordinated sphere with a newly occupied coordination site. The atropisomeric backbone exerts an outward strain associated to the large torsion angle between the two naphthalene rings ( $99.9^{\circ}$ in free ligand $2,66.7^{\circ}$ in the complex), and opposes to $\mathrm{N}_{2} \mathrm{O}_{2}$ and $\mathrm{Cu}$ being in the same plane. The long axial $\mathrm{Cu}-\mathrm{O}_{\mathrm{BINap}}$ distance $(2.309(2) \AA)$ indicates a weak coordination. Detailed analysis of the bond distances in coordinated BINap ligand shows that this $\mathrm{O}$ atom belongs to the benzoquinone part of the ligand (bond lengths in this part of the ligand of $d_{C-O}=$ $1.235(4) \AA, d_{C-C}=1.519(15) \AA$ and $\left.d_{C-N}=1.289(5) \AA\right)$ while the in plane half of the ligand corresponds to the iminosemiquinone moiety $\left(\mathrm{d}_{\mathrm{C}-\mathrm{O}}=1.288(4) \AA, \mathrm{d}_{\mathrm{C}-\mathrm{C}}=1.455(5) \AA\right.$ and $\left.\mathrm{d}_{\mathrm{C}-\mathrm{N}}=1.344(4) \AA\right) .{ }^{31}$ Such deviation from square planar geometry has been reported in the context of a salen-based $\mathrm{Cu}^{\prime \prime} \mathrm{GAO}$ functional mimic with an atropisomeric backbone by Stack and co-workers. ${ }^{38}$ DFT calculations provided insights into the electronic features of complex 1 which can be assigned as a $\mathrm{Cu}(\mathrm{II})$ center bound to a radical BINap ligand (Fig. SI-30). The system is characterized by a triplet $\mathrm{S}=1$ ground spin state due to moderate ferromagnetic coupling between the metal center and the ligand radical 
moiety (Supplementary Table S15). A singlet S=0 state is close enough in energy to be thermally populated.

Nitrogen-group transfer reaction: aziridination. We have previously reported copper-catalyzed aziridination with unstrained complex $\mathbf{4}$ bearing two independent redox-active iminosemiquinone units and exhibiting a planar geometry around the copper center (Fig. 2b) ${ }^{35}$ Complex 4 can perform aziridination on a wide range of unactivated alkenes through a mechanism involving molecular spin catalysis, related to the multistate reactivity model encountered in metalloenzymes. Aiming to assess the effect of the new tetratopic ligand $\mathbf{2}$ in comparison with two independent ditopic redox-active units, the reactivity of complex $\mathbf{1}$ in aziridination was therefore investigated.

To examine the influence of ligand strain and redox state, we performed benchmarking reactivity tests under identical conditions on all three possible redox states combinations $(\mathrm{SQ} / \mathrm{SQ}, \mathrm{SQ} / \mathrm{BQ}$ and $\mathrm{BQ} / \mathrm{BQ})$ of the redox-active units for the unstrained $(\mathbf{4}, \mathbf{6}, \mathbf{7})$ and strained $(\mathbf{3}, \mathbf{1}, \mathbf{5})$ complexes (Supplementary Table S10). Strikingly, complex 1 was found to outperform all other complexes, delivering the aziridination adduct $\mathbf{8}$ of 4-chlorostyrene in quantitative yield. These results suggest that the major reactivity improvement observed with complex $\mathbf{1}$ is linked to two factors: electronic conjugation between the $S Q$ and $B Q$ redox-active subunits and high steric strain induced by the ligand. Interestingly, the $\mathrm{SQ}-\mathrm{BQ}$ redox state $\mathrm{Cu}\left(\mathrm{L}_{\mathrm{Biphen}} \mathrm{SQ}-\mathrm{BQ}\right)^{+}$of a functional Galactose oxidase model, was suggested to be involved in the catalytic activity. This model incorporates a biphenyl unit instead of the atropisomeric binaphthyl unit, and thus retains full conjugation between the redoxactive subunits but does not exert steric strain as rotation around the arylic $\mathrm{C}-\mathrm{C}$ bond is possible in the biphenyl unit but not in the atropisomeric binaphtyl unit. ${ }^{36}$ This provides strong grounds for the role of electronic communication installed between redox-active subunits through the conjugated backbone on the redox state of the reactive complex. The second factor for the major reactivity improvement is the high steric strain observed in complex 1 . This observation is reminiscent of the entatic state model, defined as a strong steric distortion induced by ligands in a metal complex leading to improvement in catalytic activity. ${ }^{1}$

The scope of the reaction was evaluated (Scheme 1) and revealed the ability of complex 1 to perform aziridination on a wide range of substrates including mono-, di- and trisubstituted double bonds as well as electrophilic functions (11 and $\mathbf{1 4}$ ) with yields from $76 \%$ up to quantitative (8-10). Transstilbene gave the corresponding trans diastereoisomer 12 in $90 \%$ yield while cis-stilbene provided a mixture of cis- and trans-aziridines (12 and $\mathbf{1 3}$ ), thus pointing towards a probable radical mechanism accounting for cis-trans isomerization towards the most stable trans isomer. Also, conversion of unactivated alkenes ( $\mathbf{1 5}$ and $\mathbf{1 7}$ ) could be performed in up to $80 \%$ yield, while aziridination of a deactivated substrate afforded the expected product in $38 \%$ yield. Tetrasubstituted substrate 18, unreactive with complex 4 , was transformed in $86 \%$ yield within an hour. Reaction on a geraniol derivative led to products $\mathbf{1 9}$ and $\mathbf{2 0}$ in higher yield compared to the unstrained complex, and regioselectivity was reinforced towards the less hindered site in accordance with the high steric hindrance in complex 1 . The most striking results are observed when comparing catalysis with strained complex 1 and the most efficient unstrained analogue from our benchmarking reactivity test complex $4 \mathrm{Cu}(\mathrm{SQ})_{2}$. Reaction time could be divided by up to a factor 8 for compounds 10, 11, and 1620, and yields increased up to a fourty-two-fold (compound 14), thus demonstrating the efficiency of complex 1. Based on the substrate scope, average yields of $90 \%$ for styrene substrates and $73 \%$ for unactivated or hindered substrates are obtained with complex 1 while the unstrained analogue 4 provides much lower average yields ( $38 \%$ and $22 \%$ respectively). The calculated average gain in yield observed is $59 \%$ and $51 \%$ respectively (calculated as the mean value of substracted yields). This indicates that steric strain in complex $\mathbf{1}$ is accountable for a major reactivity improvement. Since the BINap ligand exhibits axial chirality, the two enantiomers of complex 1 were prepared from commercial enantiopure 1,1'-binaphthyl-2,2'- diamine and the S-isomer was tested in the reaction with 4-chlorostyrene. However, only modest enantiomeric excesses were observed with a maximum 
$35 \%$ ee (Supplementary Table S8). This could be related to the fact that the chirality inducing atropisomeric motif is remote from the coordination sites involved in the reaction, which disfavors enantioselectivity.
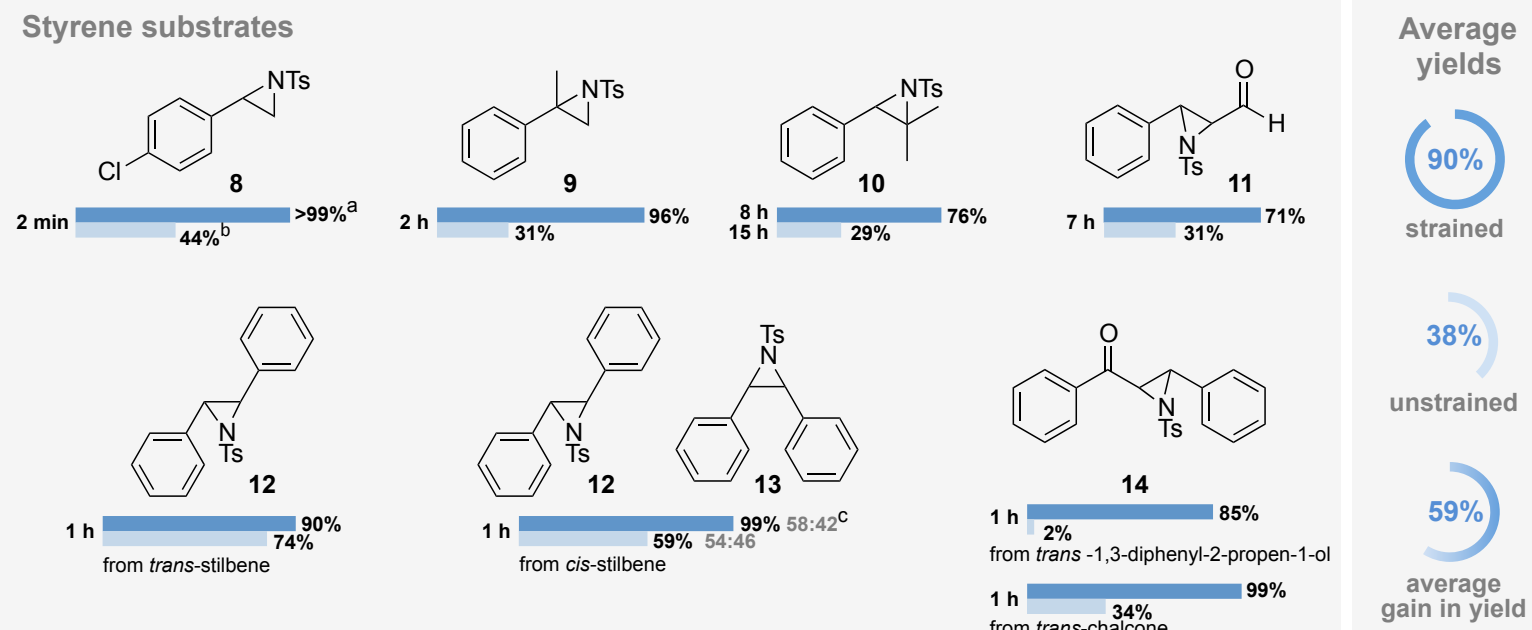

Unactivated / deactivated / sterically hindered substrates
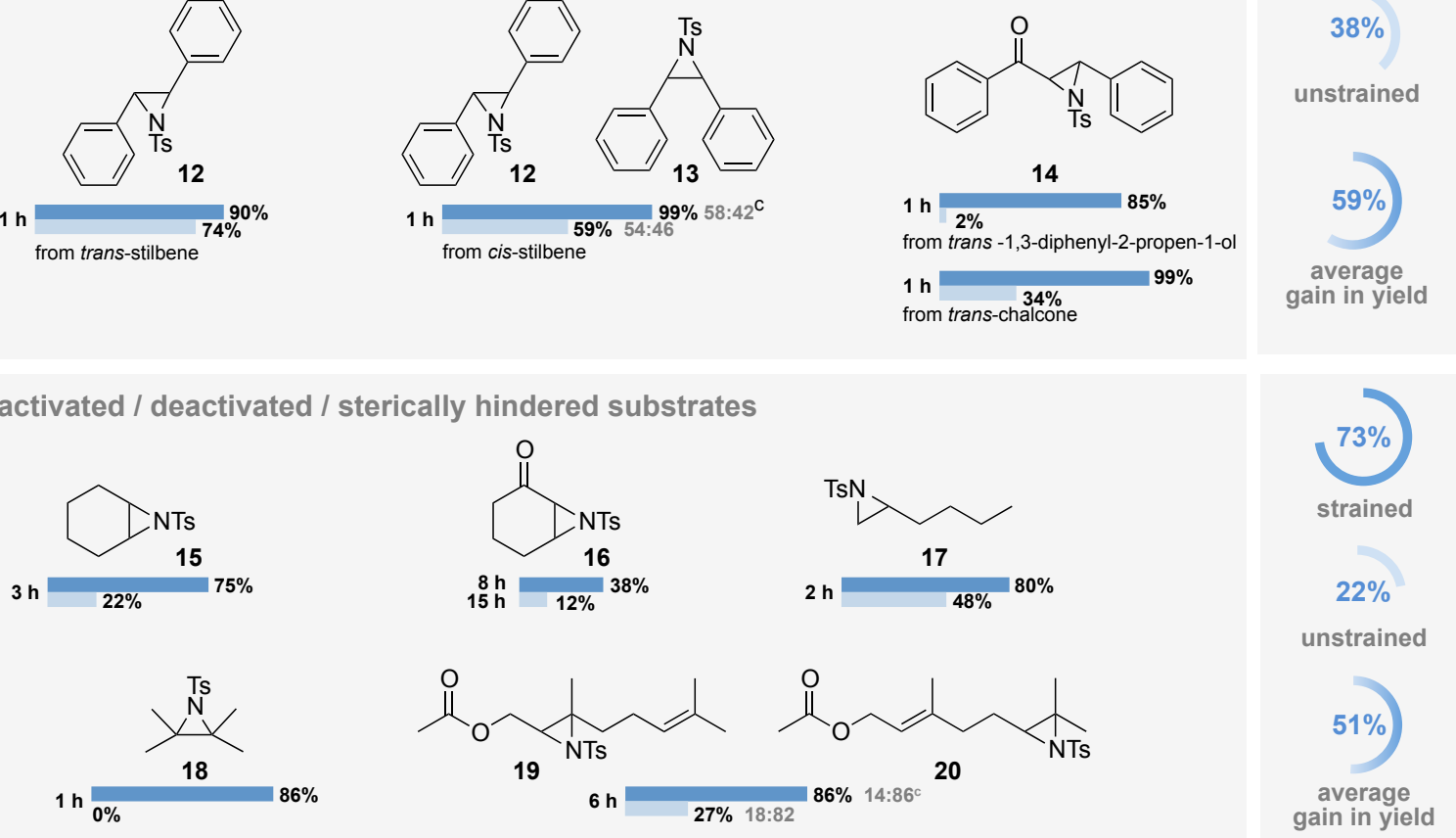

Scheme 1. Aziridination reaction performed with ${ }^{\mathrm{a}}$ complex 1 [CuBINapSQ-BQ] ${ }^{+}$(dark blue) , ${ }^{\mathrm{b}}$ complex $4 \mathrm{Cu}(\mathrm{SQ})_{2}$ (pale blue) ${ }^{\mathrm{C}}$ ratio of products (numbers in grey). ] Reaction conditions: 4-chlorostyrene (1 equiv.), PhINTs ( 2 equiv.), complex ( 5 mol\%), acetonitrile, rt. Yields were determined by ${ }^{1} \mathrm{H} N M R$ using trimethoxybenzene as internal standard and calculated considering olefin as limiting reactant.

Carbon-group transfer reaction: cyclopropanation. Having established the efficiency of complex 1 in $\mathrm{N}$-group transfer, we investigated its ability to perform C-group transfer with ethyl diazoacetate (EDA), a carbene precursor used in metal-based cyclopropanation reactions. Optimized reaction conditions (Supplementary Tables S11-14) led to the isolation of the cyclopropanated adduct 21 of 4chlorostyrene in quantitative yield, and the scope of the cyclopropanation reaction was studied (Scheme 2). A wide range of substrates including diverse mono-, and disubstituted styrene derivatives (21-26), polycyclic (27-28) substrates as well as unactivated or deactivated tri- and tetrasubstituted scaffolds (29-30) was efficiently converted. Similarly as before, complex $\mathbf{1}$ was found to systematically outperform the most efficient unstrained analogue (complex [Cu(SQ-BQ) $]^{+}$in this case) and deliver average yields of $95 \%$ and $97 \%$ on styrene derivatives and unactivated or hindered substrates respectively, while the unstrained complex reached $67 \%$ and $81 \%$ average yields respectively. This translated into average gains in yield of $21 \%$ and $16 \%$ for the two substrate scope categories. The lower gain observed with complex 1 in cyclopropanation compared to aziridination can be explained by the reaction conditions. Reaction yields are assessed over a fixed period of time set by the best performing catalyst and the reaction is stopped upon completion of maximum conversion by the best catalyst (complex $\mathbf{1}$ ). While the aziridination reaction is very fast and can be 
performed in as fast as $2 \mathrm{~min}$, the cyclopropanation conditions require that the carbene source is added slowly over 20 min to the reaction mixture to avoid unproductive homo-coupling of EDA as side-product. While this accounts for both longer reaction times and decreased gains in yield, complex 1 remains more efficient than the unstrained complex.

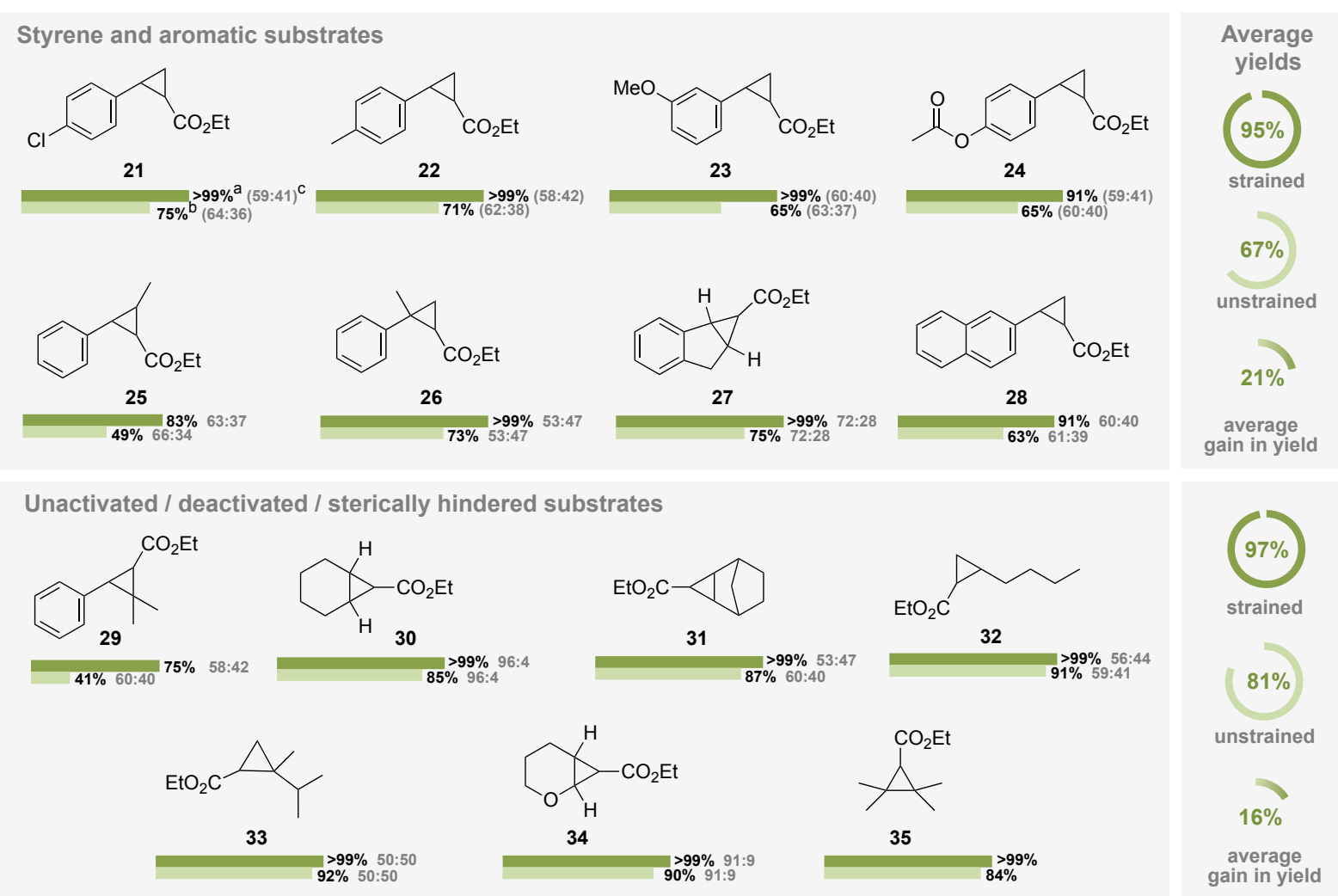

Scheme 2. Cyclopropanation reaction performed with ${ }^{\mathrm{a}}$ complex 1 [CuBINapSQ-BQ] ${ }^{+}$dark green, ${ }^{b}$ complex 6 [Cu(SQ-BQ) $]^{+}$pale green, ${ }^{\mathrm{c}}$ trans/cis ratio. Reaction conditions: 4-chlorostyrene (1 equiv.), EDA (2 equiv.), copper complex ( 1 mol\%), DCM, rt. EDA was added slowly in 20 minutes, reaction time: $20 \mathrm{~min}$. Yields were determined by ${ }^{1} \mathrm{H}$ NMR using trimethoxybenzene as internal standard and calculated considering olefin as limiting reactant.

Mechanistic studies. Mechanistically, metal-catalyzed aziridination and cyclopropanation rely on the formation of transient and highly reactive metal-carbene ${ }^{39,40}$ and metal-nitrene ${ }^{41-45}$ species, which have been actively investigated in the context of ligand noninnocence. High-resolution mass spectrometry performed on an aliquot of a mixture of complex 1 and excess nitrene (respectively carbene) source at $-80^{\circ} \mathrm{C}$ evidences the presence of a species at $\mathrm{m} / \mathrm{z} 920.3522$ (resp. $\mathrm{m} / \mathrm{z} 837.3693$ ) corresponding to the formation of mono-nitrene adduct [1-NTs] (respectively mono-carbene adduct $\left.\left[1-\mathrm{C}(\mathrm{H}) \mathrm{CO}_{2} \mathrm{Et}\right]\right)$ (Fig. SI-17, 20). UV-vis studies of complex 1 with the nitrene or carbene sources (Fig. SI-18 and -21,22) show rapid disappearance of the intervalence band around $1200 \mathrm{~nm}$, in agreement with an electron transfer from the BINapSQ-BQ ligand to the nitrene upon coordination thus generating $\left[\mathrm{Cu}\left(\mathrm{BINap}-\mathrm{BQ}_{2}\right)\right]^{2+} 5$, which does not present any $\mathrm{LLCT}$ band. To further assess the efficiency of complex 1 , reaction kinetics were studied by ${ }^{1} \mathrm{H}$ NMR and it was observed that aziridination with complex $\mathbf{1}$ is complete in less than two minutes (Fig. 3a) while cyclopropanation yields the final product in 20 min upon slow addition of EDA over the course of the reaction (Fig. $3 \mathrm{~b}$ ). 

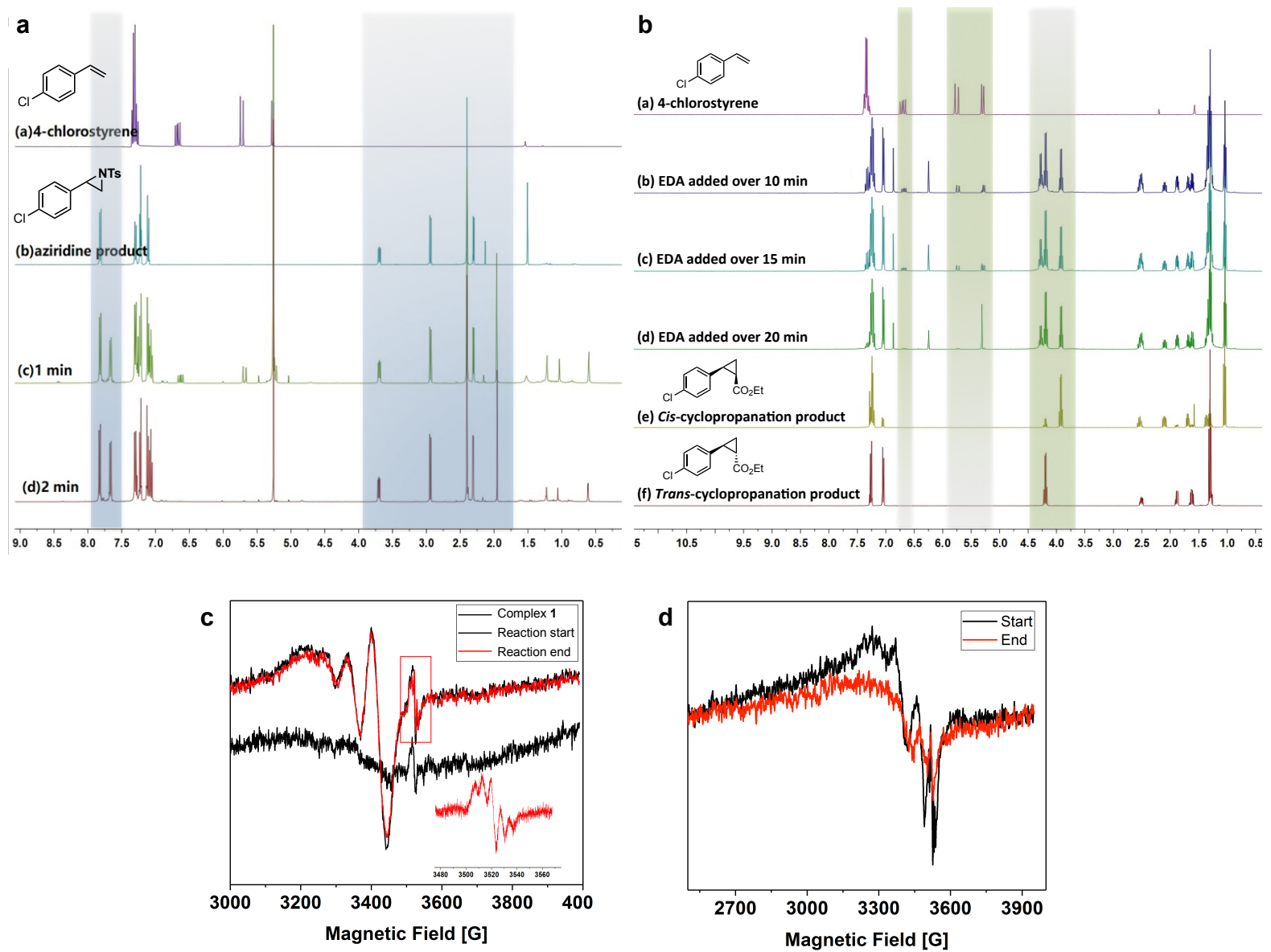

Figure 3. Operando ${ }^{1} H$ NMR and EPR studies for aziridination $(a, c)$ and cyclopropanation (b, d) of 4chlorostyrene with complex 1.

The group transfer reactions were studied by continuous wave EPR spectroscopy and operando mode, as our previous work has shown that these techniques can monitor the redox state changes of the complexes and provide structural and kinetic insights into the intermediate species (Fig. 3c and d) ${ }^{34}$ Regarding the aziridination reaction (Fig. 3c), the first important observation is the absence of spectral differences between the beginning and the end of the reaction $(2 \mathrm{~h})$, indicating that the catalytic reaction is extremely fast. X-band EPR spectra of complex 1 alone shows that the starting complex is EPR silent from $5 \mathrm{~K}$ to room temperature. However, when the aziridination reaction with complex 1 is followed by operando studies (Fig. 3c), two signals are immediately observed: one typical of a $\mathrm{Cu}^{2+}$ species ( $\mathrm{g}_{\text {iso }}=2.12$ and $\mathrm{A}_{\text {iso }}=82 \mathrm{G}$ ) and the other an organic radical displaying five lines with a coupling of $12.2 \mathrm{G}$ and an intensity ratio of $1: 2: 3: 2: 1$. The latter can be attributed to the formation of an organic radical coupled to two magnetically equivalent nitrogens. This suggests that nitrene incorporation instantaneously leads to $\mathrm{Cu}^{2+}$ species with formation a ligand-based radical, these two species not being magnetically coupled. These EPR results indicate fast electron transfer from the starting complex to the nitrene part upon coordination and are consistent with the ${ }^{1} \mathrm{H}$ NMR monitoring of the reaction showing completion of the reaction in $2 \mathrm{~min}$. Operando EPR studies attempted on the cycloproponation reaction were not conclusive as the experimental conditions implying slow addition of EDA could not be reproduced under operando conditions (Fig. $3 d)$. 


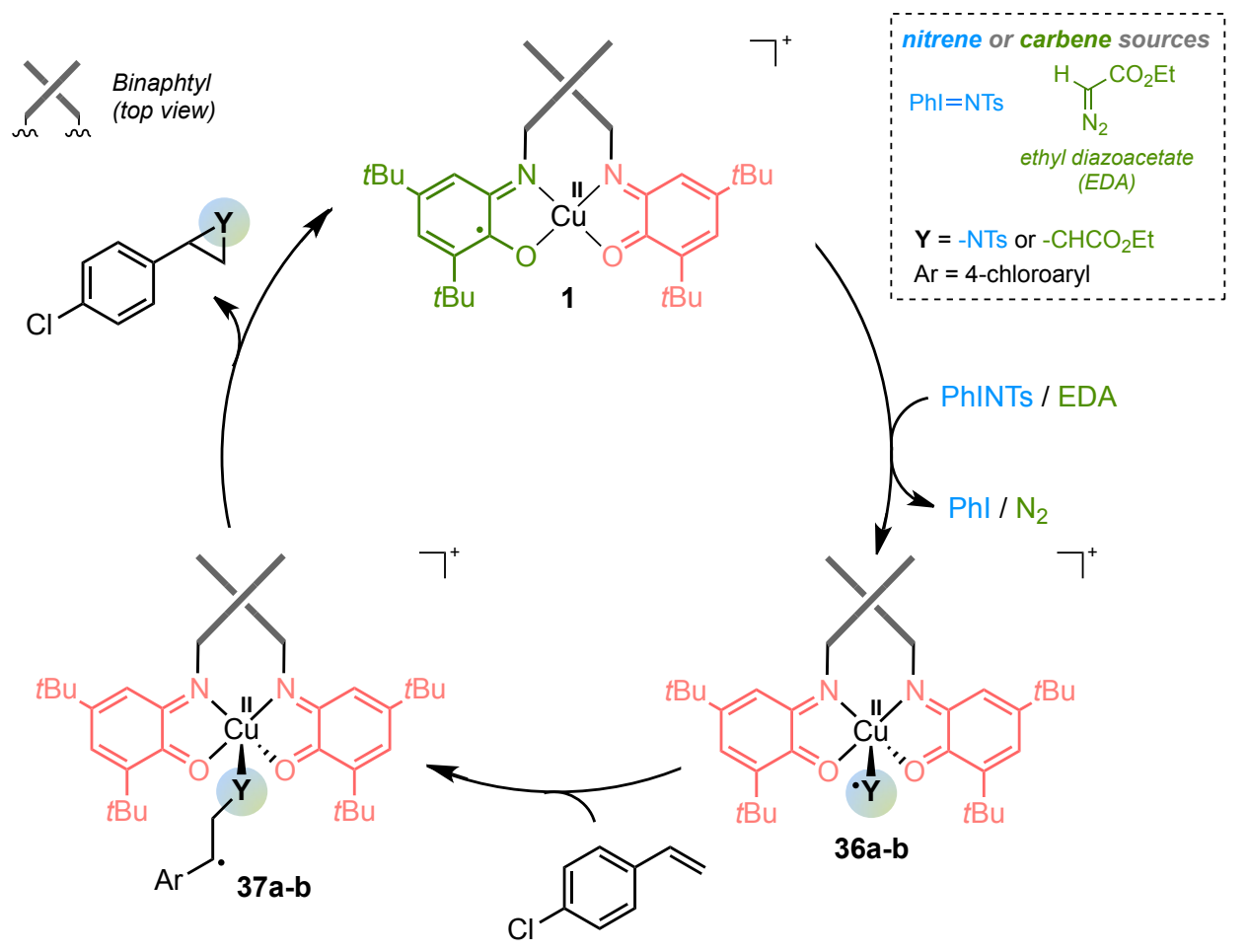

Scheme 4. Proposed catalytic cycle for $\mathrm{N}$ - and C-group transfer reactions with complex 1. a: $\mathrm{Y}=-\mathrm{NTS}$, b: $\mathrm{Y}=-\mathrm{CHCO}_{2} \mathrm{Et}$.

In light of our combined mechanistic studies, the following general mechanistic scheme can be proposed (Scheme 4). Insertion of the nitrene or carbene group on starting complex 1 generates intermediates $\mathbf{3 6} \mathbf{a}-\mathbf{b}$ (both detected by HRMS), in which the high coordinative strain and torsion angles in complex $\mathbf{1}$ are released upon reactive group coordination. Intermediates $\mathbf{3 6} \mathbf{a}-\mathbf{b}$ subsequently undergo alkene insertion to yield species 37a-b (Supplementary Fig. S35 and Table S15), and release the group-transfer product upon ring-closure. DFT calculations (Fig.4) conducted on intermediate 36a show that one SOMO is perfectly aligned with the $\mathrm{Cu}$-nitrene axis, which reflects the presence of an unpaired electron occupying a metal-based orbital having a $\mathrm{Cu} 3 \mathrm{~d}_{z}{ }^{2}$ character. The other SOMO appears mainly distributed over the $\mathrm{N}-\mathrm{SO}_{2}$ group confirming the formation of a nitrene radical moiety (Supplementary Fig. S35 and S36). This supports the triplet ground spin state of 36a due to the orthogonal character of the two SOMOs preventing magnetic coupling as observed by EPR spectroscopy. When looking at the electronic structure of 37a, we observe that the nature of the first SOMO remains metal-centered while the second SOMO is now a delocalized $\pi$-orbital distributed over the styrene moiety with the spin density being displaced from the nitrogen to the aryl group upon styrene insertion (Supplementary Fig. S37 and S38). DFT calculations conducted on intermediate $\mathbf{3 6 b}$ reveal that one SOMO features a dominant $\mathrm{Cu}$-character and the other one is a ligand-based orbital almost exclusively centered on the carbon atom of the $-\mathrm{CHCO}_{2} \mathrm{Et}$ ligand, which supports the formation of a carbene adduct (Supplementary Fig. S39 and S40). Upon styrene insertion on $\mathbf{3 6 b}$, the spin density is shifted towards the carbon center adjacent to the aryl group and the two SOMOs of 37b appear similar to those of $37 \mathrm{a}$ with one SOMO being metal-centered and the other one being ligand-based delocalized on the styrene moiety (Supplementary Fig. S41 and S42). Interestingly, a $\Delta \Delta G$ calculation comparing the relative stability of the species obtained upon nitrene and alkene insertion on strained and unstrained complexes 1 and $\mathbf{4}$ shows that intermediates 36a and $37 \mathrm{a}$ are stabilized by 2.5 and $7.1 \mathrm{kcal}^{\mathrm{mol}} \mathrm{mos}^{-1}$ respectively, in the case of complex 1 compared to complex 4 (Tables S16 and S17). These findings highlight the energetic gain observed when using the strained BINap ligand instead of the unstrained SQ, and also reflect that the highly distorted structure induced by coordination of this ligand to the metal center facilitates insertion reactions. 


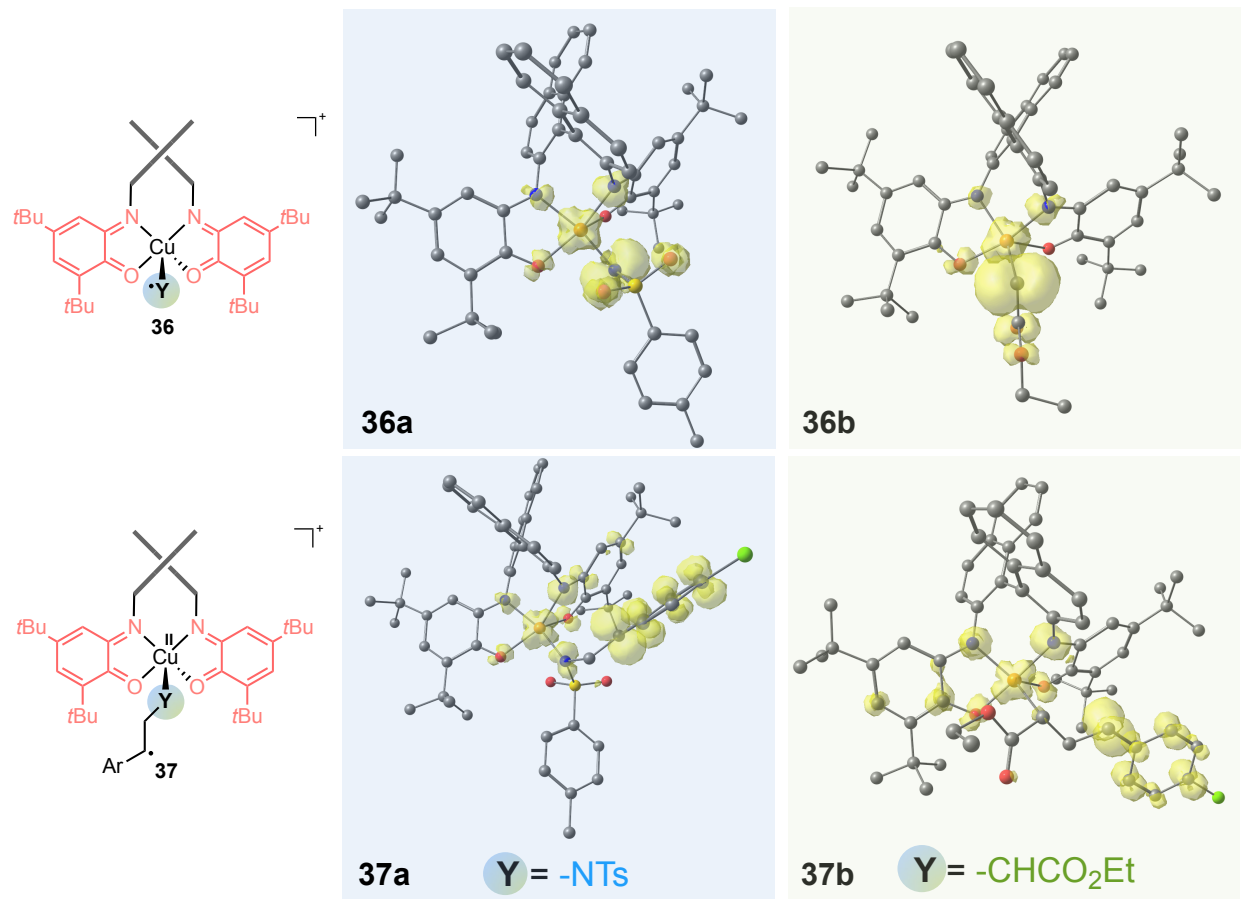

Figure 4. DFT-calculated spin density plots for intermediates $\mathbf{3 6 a - b}$ and $\mathbf{3 7 a - b}$.

In conclusion, this is the first report of group-transfer catalysis combining the entatic reactivity model and redox cofactors, which are staples of metalloenzymes' reactivity toolbox, for enhanced catalytic transformations. We have demonstrated that an atropisomeric tetratopic redox-active ligand imposing high steric and coordinative strain on a copper center can perform group transfer reactions up to eight times faster than related unstrained systems. The redox-active atropisomeric backbone establishes electronic communication between the two redox-active subunits, thus favoring intramolecular electron transfer during catalysis and maintaining a $\mathrm{Cu}^{\prime \prime}$ redox homeostasis. This system bridges the gap between small-molecule enzymatic structural models focused on the design of the first coordination sphere and top-down approaches achieving control over the aminoacid secondary and tertiary coordination spheres by directed enzymatic evolution. ${ }^{46}$ This work shows that the combination of enzymatic reactivity-enabling strategies offers a new and promising approach to reactivity control in bioinspired catalysis, and should open the door towards more challenging synthetic reactions.

\section{References}

1. Adesina, O., Anzai, I. A., Avalos, J. L. \& Barstow, B. Embracing Biological Solutions to the Sustainable Energy Challenge. Chem 2, 20-51 (2017).

2. Rudroff, F. et al. Opportunities and challenges for combining chemo- and biocatalysis. Nat. Catal. 1, 12-22 (2018).

3. Vallee, B. L. \& Williams, R. J. Metalloenzymes: the entatic nature of their active sites. Proc. Natl. Acad. Sci. 59, 498-505 (1968).

4. Williams, R. J. P. Catalysis by metallo-enzymes: The entatic state. Inorganica Chim. Acta Rev. 5, 137-155 (1971).

5. Williams, R. J. P. Energised (entatic) States of Groups and of Secondary Structures in Proteins and Metalloproteins. Eur. J. Biochem. 234, 363-381 (1995).

6. Stanek, J., Hoffmann, A. \& Herres-Pawlis, S. Renaissance of the entatic state principle. Coord. Chem. Rev. 365, 103-121 (2018).

7. Freiberger, M. I., Guzovsky, A. B., Wolynes, P. G., Parra, R. G. \& Ferreiro, D. U. Local frustration around enzyme active sites. Proc. Natl. Acad. Sci. 116, 4037-4043 (2019).

8. Comba, P. Coordination compounds in the entatic state. Coord. Chem. Rev. 200-202, 217-245 (2000). 
9. a) E. Müller, G. Bernardinelli, J. Reedijk, Inorg. Chem., 1996, 35, 1952; b) E. Müller, C. Piguet, G. Bernardinelli, A.F. Williams, Inorg. Chem. 1988, 27, 849; c) M.R. Malachowski, M. Adams, N. Elia, A.L. Rheingold, R.S. Kelly, J. Chem. Soc. Dalton Trans. 1999, 2177.

10. Garcia, L. et al. Entasis through Hook-and-Loop Fastening in a Glycoligand with Cumulative Weak Forces Stabilizing Cul. J. Am. Chem. Soc. 137, 1141-1146 (2015).

11. Hoffmann A. et al. Catching an Entatic State-A Pair of Copper Complexes. Angew. Chem. Int. Ed. 53, 299304 (2013).

12. Stanek J. et al. Copper Guanidinoquinoline Complexes as Entatic State Models of Electron-Transfer Proteins. Chem. - Eur. J. 23, 15738-15745 (2017).

13. Dicke, B. et al. Transferring the entatic-state principle to copper photochemistry. Nat. Chem. 10, 355-362 (2018).

14. Mara, M. W. et al. Metalloprotein entatic control of ligand-metal bonds quantified by ultrafast x-ray spectroscopy. Science 356, 1276-1280 (2017).

15. Snyder, B. E. R. et al. The active site of low-temperature methane hydroxylation in iron-containing zeolites. Nature 536, 317-321 (2016).

16. Comba, P. et al. A Bispidine Iron(IV)-Oxo Complex in the Entatic State. Angew. Chem. Int. Ed. 55, 1112911133 (2016).

17. Stubbe, J. \& van der Donk, W. A. Protein Radicals in Enzyme Catalysis. Chem. Rev. 98, 705-762 (1998).

18. Davidson, V. L. Protein-Derived Cofactors Revisited: Empowering Amino Acid Residues with New Functions. Biochemistry 57, 3115-3125 (2018).

19. Grützmacher, H. Cooperating Ligands in Catalysis. Angew. Chem. Int. Ed. 47, 1814-1818 (2008).

20. Chirik, P. J. \& Wieghardt, K. Radical Ligands Confer Nobility on Base-Metal Catalysts. Science 327, 794-795 (2010).

21. Praneeth, V. K. K., Ringenberg, M. R. \& Ward, T. R. Redox-Active Ligands in Catalysis. Angew. Chem. Int. Ed. 51, 10228-10234 (2012).

22. van der Vlugt, J. I. Cooperative Catalysis with First-Row Late Transition Metals. Eur. J. Inorg. Chem. 2012, 363-375 (2012).

23. Blanchard, S. et al. Non-Innocent Ligands: New Opportunities in Iron Catalysis. Eur. J. Inorg. Chem. 2012, 376-389 (2012).

24. Lyaskovskyy, V. \& de Bruin, B. Redox Non-Innocent Ligands: Versatile New Tools to Control Catalytic Reactions. ACS Catal 2, 270-279 (2012).

25. Luca, O. R. \& Crabtree, R. H. Redox-active ligands in catalysis. Chem. Soc. Rev. 42, 1440-1459 (2012).

26. Broere, D. L. J., Plessius, R. \& Vlugt, J. I. van der. New avenues for ligand-mediated processes - expanding metal reactivity by the use of redox-active catechol, o-aminophenol and o-phenylenediamine ligands. Chem. Soc. Rev. 44, 6886-6915 (2015).

27. Kaim, W. Manifestations of Noninnocent Ligand Behavior. Inorg. Chem. 50, 9752-9765 (2011).

28. Albold, U. et al. Isolable Cu(I) Complexes of Extremely Electron-Poor, Completely Unreduced o-Quinone and "Di-o-Quinone" Ligands Stabilized through $\pi-\pi$ Interactions in the Secondary Coordination Sphere. Inorg.

Chem. 58, 3754-3763 (2019).

29. Schrempp David F. et al. Inter- and Intramolecular Electron Transfer in Copper Complexes: Electronic Entatic State with Redox-Active Guanidine Ligands. Chem. - Eur. J. 23, 13607-13611 (2017).

30. Chaudhuri, P., Hess, M., Flörke, U. \& Wieghardt, K. From Structural Models of Galactose Oxidase to Homogeneous Catalysis: Efficient Aerobic Oxidation of Alcohols. Angew. Chem. Int. Ed. 37, 2217-2220 (1998). 31. Chaudhuri, P. et al. Electronic Structure of Bis(o-iminobenzosemiquinonato)metal Complexes (Cu, Ni, Pd). The Art of Establishing Physical Oxidation States in Transition-Metal Complexes Containing Radical Ligands. J. Am. Chem. Soc. 123, 2213-2223 (2001).

32. Jacquet, J., Blanchard, S., Derat, E., Desage-El Murr, M. \& Fensterbank, L. Redox-ligand sustains controlled generation of $\mathrm{CF}_{3}$ radicals by well-defined copper complex. Chem. Sci. 7, 2030-2036 (2016).

33. Jacquet, J. et al. Circumventing Intrinsic Metal Reactivity: Radical Generation with Redox-Active Ligands. Chem. - Eur. J. 23, 15030-15034 (2017).

34. Jacquet, J. et al. C-N Bond Formation from a Masked High-Valent Copper Complex Stabilized by Redox NonInnocent Ligands. Angew. Chem. Int. Ed. 55, 10712-10716 (2016).

35. Ren, Y. et al. Copper-Catalyzed Aziridination with Redox-Active Ligands: Molecular Spin Catalysis. Chem. Eur. J. 24, 5086-5090 (2018).

36. Mukherjee, C., Weyhermüller, T., Bothe, E. \& Chaudhuri, P. Targeted Oxidase Reactivity with a New RedoxActive Ligand Incorporating N2O2 Donor Atoms. Complexes of $\mathrm{Cu}(\mathrm{II}), \mathrm{Ni}(\mathrm{II}), \mathrm{Pd}(\mathrm{II}), \mathrm{Fe}(\mathrm{III})$, and V(V). Inorg. Chem. 47, 11620-11632 (2008). 
37. From a CCDC database search, out of 126 structures of 5-coordinated Cu complexes bearing $\left\{(\mathrm{NCCO})_{2}+\right.$ $\left.\mathrm{OH}_{2}\right\}$ coordination sphere, only five do not display a square pyramidal geometry with water as apical ligand. 38. Wang, Y., DuBois, J. L., Hedman, B., Hodgson, K. O. \& Stack, T. D. P. Catalytic Galactose Oxidase Models: Biomimetic Cu(II)-Phenoxyl-Radical Reactivity. Science 279, 537-540 (1998).

39. Dzik, W. I., Xu, X., Zhang, X. P., Reek, J. N. H. \& de Bruin, B. 'Carbene Radicals' in Coll(por)-Catalyzed Olefin Cyclopropanation. J. Am. Chem. Soc. 132, 10891-10902 (2010).

40. Dzik, W. I., Zhang, X. P. \& de Bruin, B. Redox Noninnocence of Carbene Ligands: Carbene Radicals in (Catalytic) C-C Bond Formation. Inorg. Chem. 50, 9896-9903 (2011).

41. Suarez, A. I. O., Lyaskovskyy, V., Reek, J. N. H., van der Vlugt, J. I. \& de Bruin, B. Complexes with NitrogenCentered Radical Ligands: Classification, Spectroscopic Features, Reactivity, and Catalytic Applications. Angew. Chem. Int. Ed. 52, 12510-12529 (2013).

42. Goswami, M. et al. Characterization of Porphyrin-Co(III)-'Nitrene Radical’ Species Relevant in Catalytic Nitrene Transfer Reactions. J. Am. Chem. Soc. 137, 5468-5479 (2015).

43. Corona, T. et al. Characterization and Reactivity Studies of a Terminal Copper-Nitrene Species. Angew. Chem. Int. Ed. 55, 14005-14008 (2016).

44. Kuijpers, P., van der Vlugt, J. I., Schneider, S. \& de Bruin, B. Nitrene Radical Intermediates in Catalytic Synthesis. Chem. - Eur. J. 23, 13819-13829 (2017).

45. Fujita, D., Sugimoto, H., Morimoto, Y. \& Itoh, S. Noninnocent Ligand in Rhodium(III)-Complex-Catalyzed C-H Bond Amination with Tosyl Azide. Inorg. Chem. 57, 9738-9747 (2018).

46. Arnold Frances H. Directed Evolution: Bringing New Chemistry to Life. Angew. Chem. Int. Ed. 57, 4143-4148 (2017).

\section{Acknowledgements}

The authors would like to thank Sorbonne Université (SU), Université de Strasbourg, CNRS, IR-RPE CNRS FR3443 RENARD network (CW X-band EPR with Dr. J.-L. Cantin, INSP UMR CNRS 7588, SU and $X$-band EPR in Lille). SU is acknowledged for an Emergence grant (M.D.E.M. and K.C.) and CSC for a PhD fellowship (Y.R.). The authors gratefully acknowledge the COST Action 27 CM1305 ECOSTBio and FrenchBIC network. We would also like to thank Dr Vincent Lebrun, CNRS, Université de Strasbourg, for valuable discussions. 


\title{
High-performance group transfer catalysis by copper complex with redox-active ligand in an entatic state
}

\author{
Y. Ren, ${ }^{[a]}$ J. Forté, ${ }^{[a]}$ K. Cheaib, ${ }^{[a]}$ N. Vanthuyne, ${ }^{[b]}$ L. Fensterbank $^{[a]}$ H. Vezin, ${ }^{[c]}$ M. Orio, ${ }^{[b]}$ S.
} Blanchard, ${ }^{[\mathrm{a}]}$ and M. Desage-El Murr ${ }^{[\mathrm{d}] *}$

anstitut Parisien de Chimie Moléculaire (IPCM - UMR CNRS 8232), UPMC Univ-Paris 06, Sorbonne Universités, 4 place Jussieu, C.229, 75252 Paris cedex 05 (France).

${ }^{b}$ iSm2, Université Aix-Marseille, Campus Scientifique de St Jérôme, Marseille (France).

'Laboratoire de Spectrochimie Infrarouge et Raman, Université des Sciences et Technologies de Lille, UMR CNRS 8516, 59655 Villeneuve d'Ascq Cedex (France).

${ }^{d}$ Institut de Chimie, Université de Strasbourg, 1 rue Blaise Pascal 67000 Strasbourg (France)

\section{SUPPORTING INFORMATION}

General Information.

Synthesis and characterization of BINap ligand 2 ......

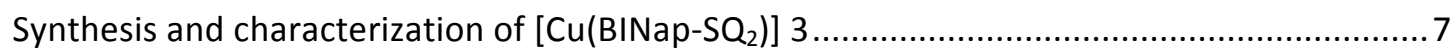

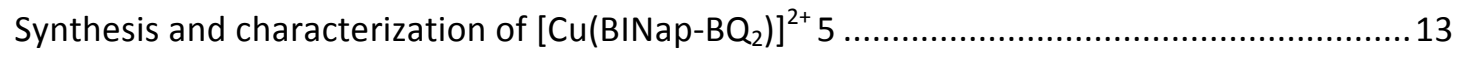

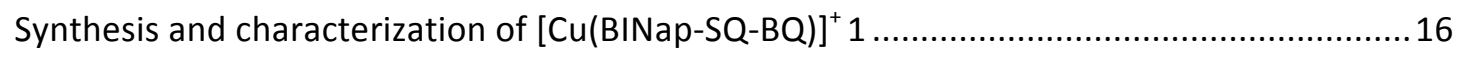

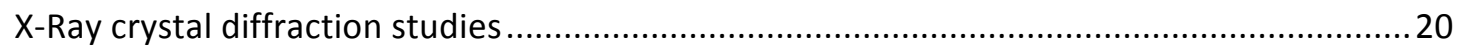

Representative procedure for the aziridination....................................................26

Mechanistic studies of aziridination by mass spectrometry, UV-vis and ${ }^{1} \mathrm{H}$ NMR

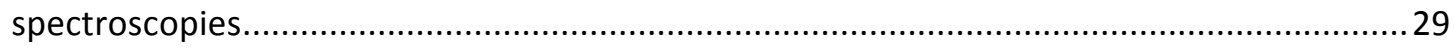

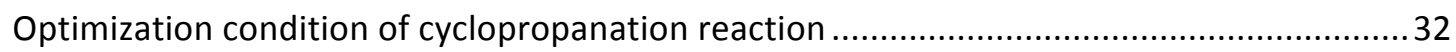

Representative procedure for the cyclopropanation ............................................... 33

Mechanistic studies of cyclopropanation by mass spectrometry, UV-vis and ${ }^{1} \mathrm{H}$ NMR

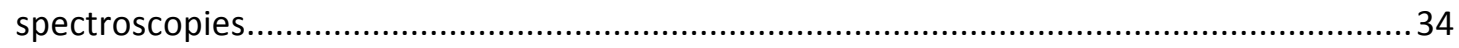

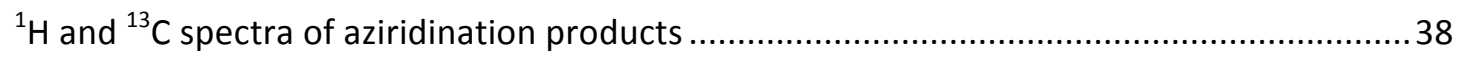

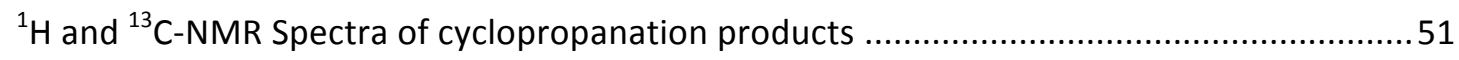

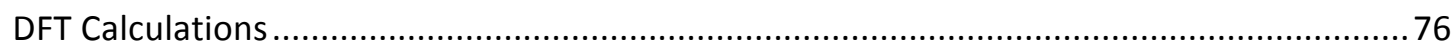




\section{General Information}

All reactions were performed under argon atmosphere, in flame dried glassware with magnetic stirring using standard Schlenk techniques, unless otherwise mentionned. MeCN and $\mathrm{CH}_{2} \mathrm{Cl}_{2}$ were distilled over calcium hydride and were purged with argon prior to use. All other reagents were purchased from commercial sources (Sigma-Aldrich, Alfa Aesar, Fluorochem, Strem Chemicals) and were used without purification, unless otherwise noted. Thin layer chromatography (TLC) was performed on Merck 60 F254 silica gel and visualized with a UV lamp (254 nm) or with a potassium permanganate solution. ${ }^{1} \mathrm{H}$ NMR and ${ }^{13} \mathrm{C}$ NMR spectra were recorded at room temperature unless otherwise required on a Bruker Avance $300 \mathrm{MHz}$ or a Bruker Avance $400 \mathrm{MHz}$ spectrometer. Trimethoxybenzene was used as an internal standard to determine ${ }^{1} \mathrm{H}$ NMR yield. Shifts $(\delta)$ are given in parts per million (ppm) and coupling constants $(J)$ are given in Hertz $(\mathrm{Hz})$. High-resolution mass spectrometry was performed on a BrukermicroTOF (ESI) spectrometer. UV-Vis-NIR was recorded using JASCO V670 spectrophotometer. Wavelengths $(\lambda)$ are given in nanometer $(\mathrm{nm})$ and molar extinction coefficients $(\varepsilon)$ are given in $\mathrm{M}^{-1} \cdot \mathrm{cm}^{-1}$. The circular dichroism was performed on a JASCOJ-815 CD spectrometer equipped with a JASCO CDF-426L Peltierthermostat $(2 \mathrm{~mm}$ quartz cell). Preparative chiral HPLC of HELIXOL was achieved on an Agilent 1260 infinity unit with pump, autosampler, oven, DAD and JASCO CD-2095 circular dichroism detector, controlled by SRA Instrument software. X-band EPR spectra were recorded in non saturating conditions on a Bruker ELEXSYS 500 spectrometer equipped with an Oxford instrument continuous-flow liquid-helium cryostat and a temperature control system. CW in situ experiments were performed using an X band ELEXSYS 500 E spectrometer. The spectra were measured at room temperature using a $2 \mathrm{~mm}$ quartz cell. Microwave power and amplitude modulation were respectively set to $2 \mathrm{~mW}$ and $1 \mathrm{G}$. Cyclic voltammograms were recorded using OrigaFlex-Pack OGF500, and were performed in dichloromethane solutions containing $0.1 \mathrm{M} \mathrm{TBAPF}_{6}$ as the supporting electrolyte at a glassy carbon working electrode, a $\mathrm{KCl}$ saturated calomel reference electrode, and a platinum wire as a counter electrode. X-Ray crystal structure determination: a single crystal was selected, mounted and transferred into a cold nitrogen gas stream. Intensity data was collected with a Bruker Kappa-APEX2 system using micro-source $\mathrm{Cu}-\mathrm{K} \alpha$ radiation. Unit-cell parameters 
determination, data collection strategy and integration were carried out with the Bruker APEX2 suite of programs. Multi-scan absorption correction was applied. The structure was solved with SHELXS-86 and refined anisotropically by full-matrix least-squares methods using CRYSTALS. Structures were deposited at the International Union of Crystallography and can be obtained free of charge via checkcif.iucr.org 


\section{Synthesis and characterization of BINap ligand 2}<smiles>CC(C)(C)c1cc(O)c(O)c(C(C)(C)C)c1</smiles><smiles>Nc1ccc2ccccc2c1-c1c(N)ccc2ccccc12</smiles>

(Rac)-1,1'-Binaphthyl-2,2'-diamine

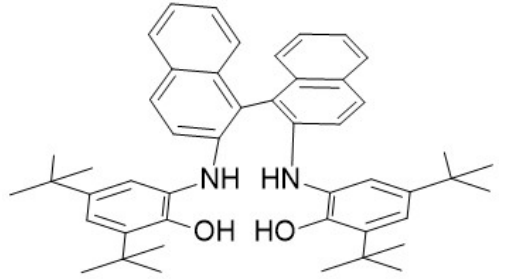

(Rac)- BINap Ligand 2

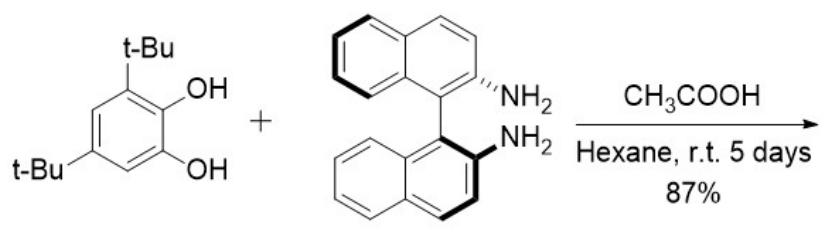

(S)-(-)-1,1'-Binaphthyl-2,2'-diamine

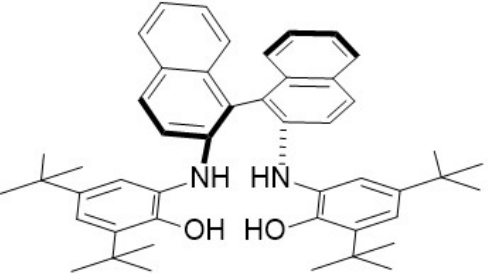

(S)- BINap Ligand 2<smiles>CC(C)(C)c1cc(O)c(O)c(C(C)(C)C)c1</smiles>

(R)-(+)-1,1'-Binaphthyl-2,2'-diamine

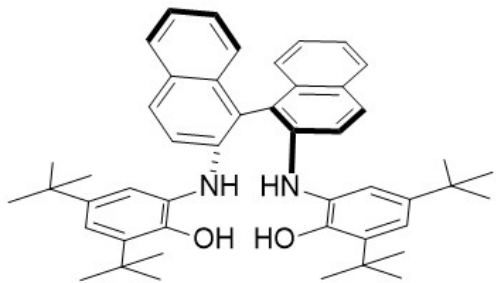

(R)-BINap Ligand 2

A $100 \mathrm{~mL}$ round bottomed flask with stirrer bar was charged with 1,1'-binaphthyl-2,2'-diamine (1.136 g, $4 \mathrm{mmol})$ and 3,5-di-tert-butylcatechol (1.776 g, 8 $\mathrm{mmol})$. Hexane $(40 \mathrm{~mL}$ ) was added and $0.2 \mathrm{~mL}$ glacial acetic acid was added after 10 minutes. The reaction was stirred for 5 days at room temperature. The reaction mixture was filtered to remove the precipitate and the filtrate was evaporated under reduced pressure to afford the crude product. Recrystallization in acetonitrile provided the final product as a pale white powder. (Procedure adapted from the literature) ${ }^{1}$

${ }^{1}$ H NMR $\left(400 \mathrm{MHz}, \mathrm{CDCl}_{3}\right) \delta=7.88-7.81(\mathrm{~m}, 4 \mathrm{H}), 7.38-7.27(\mathrm{~m}, 6 \mathrm{H}), 7.18(\mathrm{~d}, \mathrm{~J}=2.4,2 \mathrm{H})$, $7.04(\mathrm{~d}, J=9.0,2 \mathrm{H}), 6.91(\mathrm{~d}, \mathrm{~J}=2.4,2 \mathrm{H}), 6.43(\mathrm{~s}, 2 \mathrm{H}), 1.40(\mathrm{~s}, 18 \mathrm{H}), 1.20(\mathrm{~s}, 18 \mathrm{H})$.

${ }^{13} \mathrm{C}$ NMR $\left(101 \mathrm{MHz}, \mathrm{CDCl}_{3}\right) \delta=149.7,144.0,142.3,135.4,133.5,130.1,129.3,128.5,127.9$, $127.3,123.9,123.6,122.3,122.0,116.9,114.6,34.9,34.3,31.5,29.5$.

HRMS (ESI) calculated for $\mathrm{C}_{48} \mathrm{H}_{56} \mathrm{~N}_{2} \mathrm{O} 692.4342$, found [M+Na] $]^{+} 715.4233$.

\footnotetext{
${ }^{1}$ F. D. Lesh, R. L. Lord, M. J. Heeg, H. B. Schlegel, C. N. Verani, Eur. J. Inorg. Chem. 2012, 463-466.
} 

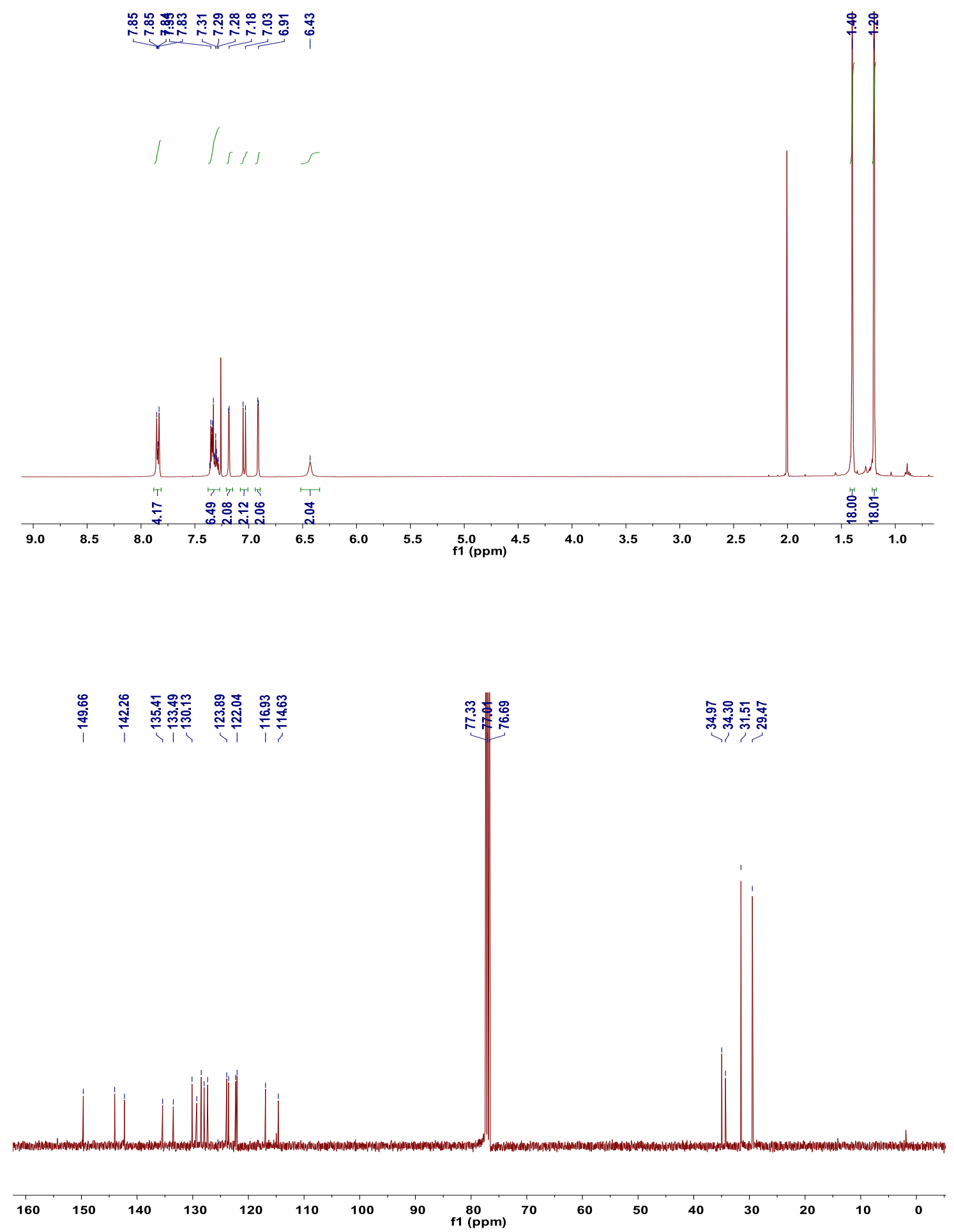


\section{Circular dichroism of BINap ligand 2}

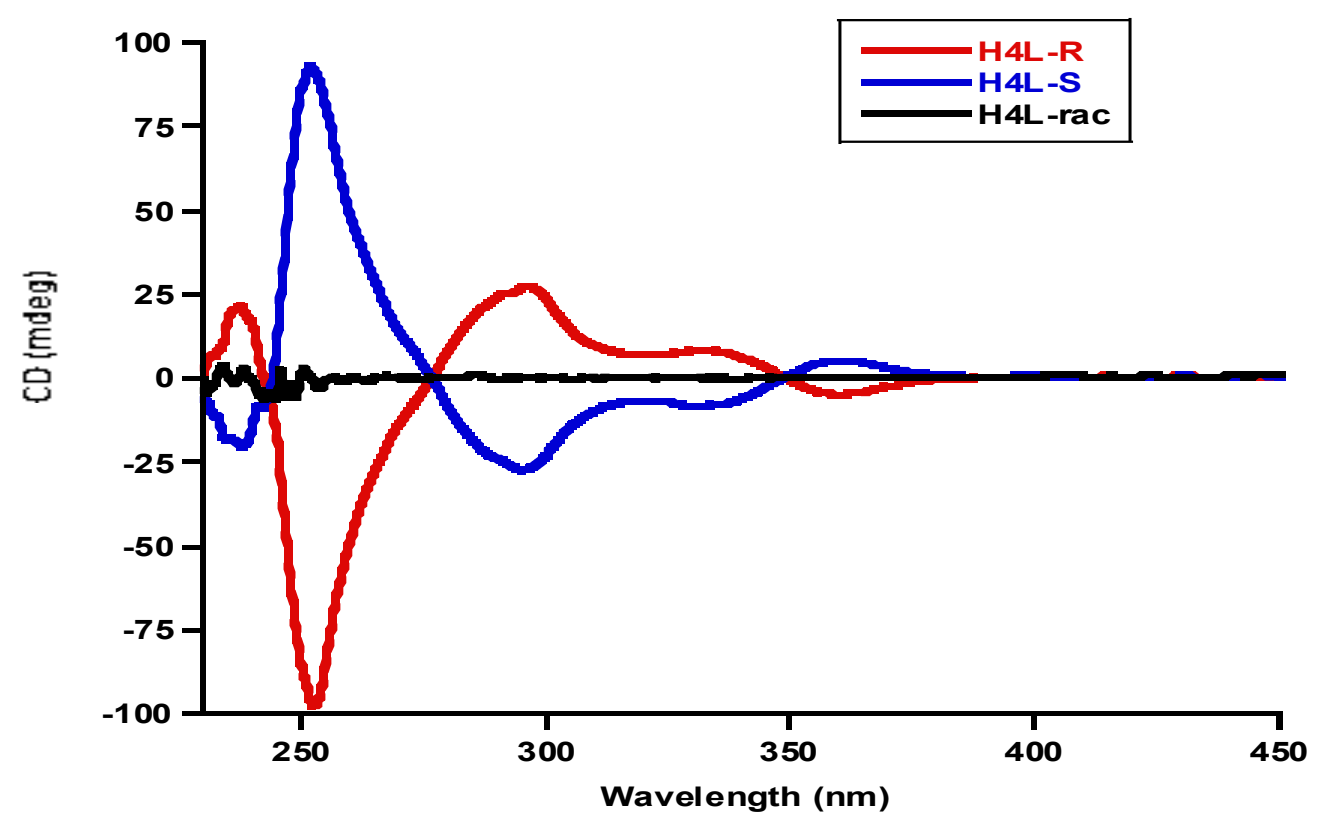

Figure SI-1: Circular dichroism spectra of enantiopure (R), (S), and racemic BINap ligand 2

$$
(\mathrm{c}=0.3 \mathrm{mM}) \text { in DCM }
$$

CD spectrum of S-ligand 2 (blue line) exhibits an intense positive band around (+) $251 \mathrm{~nm}$, and a broad negative band at (-) $294 \mathrm{~nm}$ accompanied with a shoulder at $332 \mathrm{~nm}$. CD spectrum of R-ligand $\mathbf{2}$ (red line) shows the opposite trend. It disclosed an intense negative band around (-) $252 \mathrm{~nm}$, and a broad positive band at (+) $295 \mathrm{~nm}$ accompanied with a shoulder at $333 \mathrm{~nm}$. CD spectrum of racemate-ligand $\mathbf{2}$ (black line) is almost a straight line, no absorption band. 


\section{Synthesis and characterization of $\left[\mathrm{Cu}\left(\mathrm{BINap}-\mathrm{SQ}_{2}\right)\right] 3$}

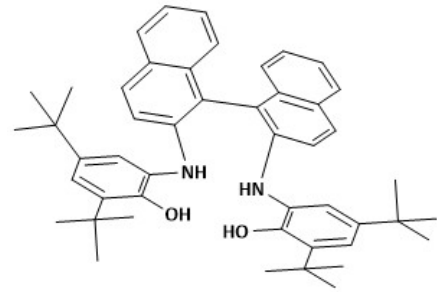

(Rac)-Ligand 2

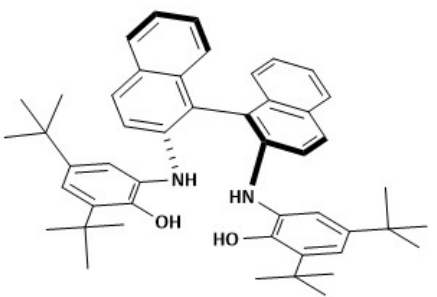

(R)-Ligand 2

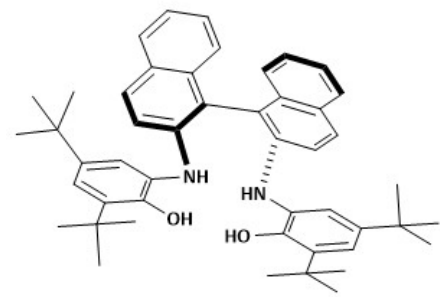

(S)-Ligand 2

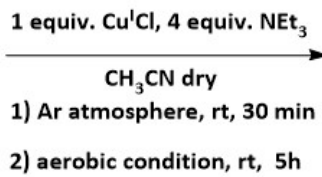

$90 \%$

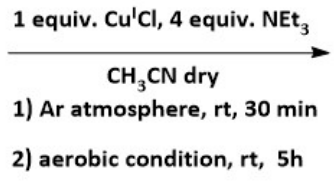

$89 \%$

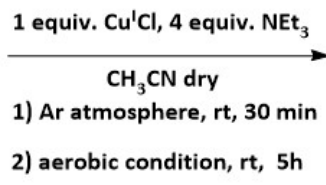

$92 \%$

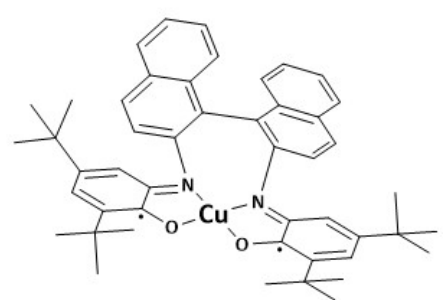

(Rac)-Cu(BINap-SQ ${ }_{2}$ )

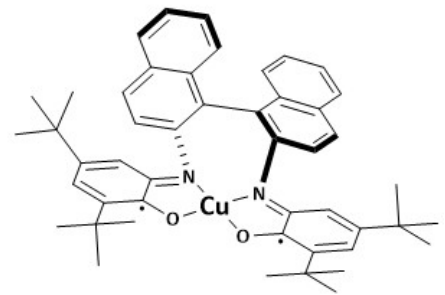

(R)-Cu(BINap-SQ ${ }_{2}$ )

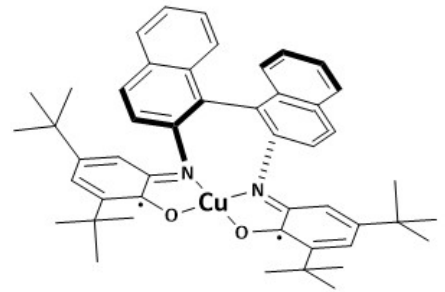

(S)-Cu(BINap-SQ 2 )

BINap Ligand 2 (500 mg, $0.722 \mathrm{mmol}, 1$ equiv.) was introduced in a flame-dried schlenk, which was back-filled three times with argon. Degassed $\mathrm{MeCN}(30 \mathrm{~mL})$ and $\mathrm{Et}_{3} \mathrm{~N}(0.4 \mathrm{ml}, 4$ equiv.) were added at room temperature and the mixture was left to stir for 10 minutes. $\mathrm{CuCl}$ (71 mg, $0.722 \mathrm{mmol}, 1$ equiv.) was added and the mixture was stirred for 30 minutes under argon. The resulting light green suspension was left to stir for $5 \mathrm{~h}$ under air at room temperature. The suspension turned dark green and the precipitate slowly disappeared. As the time went, a dark green precipitate appeared. The dark green complex was filtered and washed with cold acetonitrile. (Procedure adapted from the literature ${ }^{2}$ ).

HRMS (ESI) calculated for $\mathrm{C}_{48} \mathrm{H}_{52} \mathrm{CuN}_{2} \mathrm{O}_{2} 751.3325$, found [M] $]^{+} 751.34$.

${ }^{2}$ C. Mukherjee, T. Weyhermüller, E. Bothe, P. Chaudhuri, Inorg. Chem. 2008, 47, 11620-11632. 


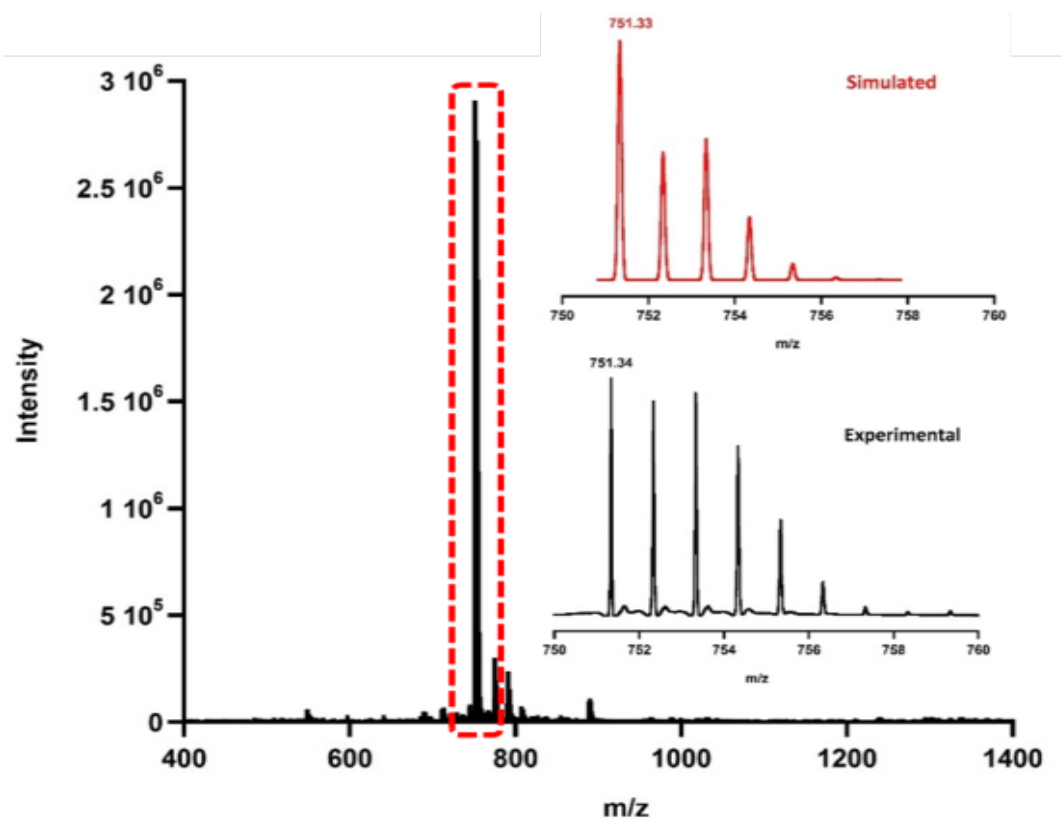

Figure SI-2: HRMS mass spectrum of [Cu(BINap-SQ 2$)]$

\section{Circular dichroism study of [Cu(BINap-SQ 2$)] 3$}

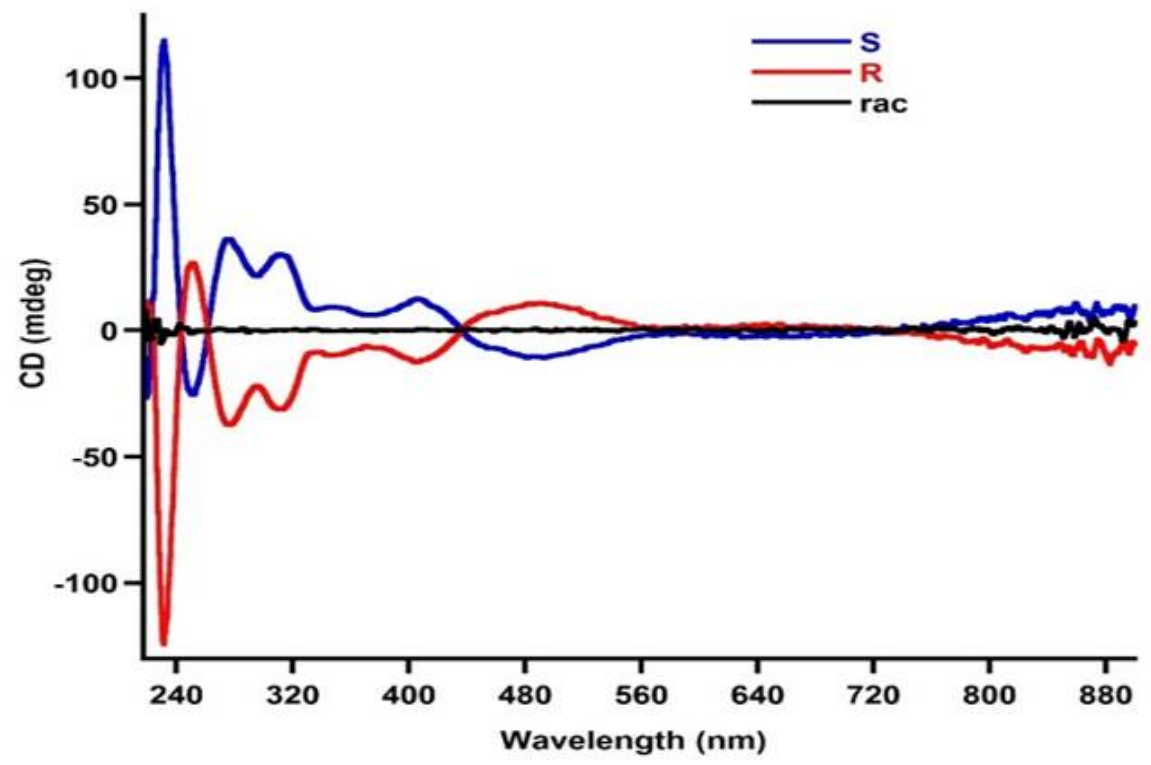

Figure SI-3:Circular Dichroism spectrum of $\left[\mathrm{Cu}\left(\mathrm{BINap}-\mathrm{SQ}_{2}\right)\right](\mathrm{C}=0.3 \mathrm{mM})$

$\mathrm{CD}$ spectrum of $\mathrm{S}-\left[\mathrm{Cu}\left(\mathrm{BINap}-\mathrm{SQ}_{2}\right)\right]$ (blue line) disclosed an intense positive band around $(+)$ $231 \mathrm{~nm}$, and a broad positive band with 4 shoulders at (+) 275, 310, 347 and $406 \mathrm{~nm}$. Besides, it has two small negative bands at (-) 251 and $493 \mathrm{~nm}$. The curve of $\mathrm{R}-\left[\mathrm{Cu}\left(\mathrm{BINap}-\mathrm{SQ}_{2}\right)\right]$ (red line) is exactly the opposite and the strength of absorption bands are very similar with S-[Cu(BINap-SQ 2$)]$. CD spectrum of Racemate-[Cu(BINap-SQ $\left.\left.\mathrm{S}_{2}\right)\right]$ (black line) is 
silence.

Figure SI-4 Chiral HPLC report of [Cu(BINap-SQ2)] 3

Sample name: Rac-[Cu(BINap-SQ $\left.\left.{ }_{2}\right)\right]$

Column: Chiralpak IE

Temperature: 10 degres

Mobile phase: Heptane/dichloromethane (90/10), $1 \mathrm{~mL} / \mathrm{min}$

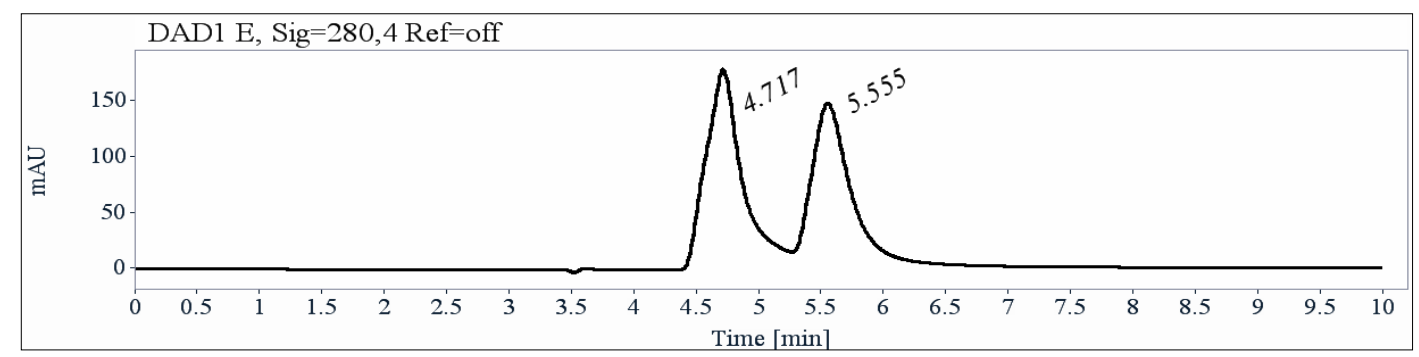

Signal: $\quad$ DAD1 E, Sig $=280,4$ Ref $=$ off

\begin{tabular}{|c|c|c|c|c|c|}
\hline RT [min] & Area & Area\% & Capacity Factor & Enantioselectivity & Resolution (USP) \\
\hline 4.72 & 3659 & 52.70 & 0.60 & & \\
\hline 5.56 & 3284 & 47.30 & 0.88 & 1.47 & 1.56 \\
\hline Sum & 6943 & 100.00 & & & \\
\hline
\end{tabular}

Sample name: $\quad \mathrm{S}-\left[\mathrm{Cu}\left(\mathrm{BINap}-\mathrm{SQ}_{2}\right)\right]$

Column: Chiralpak IE

Temperature: 10 degres

Mobile phase: Heptane/dichloromethane (90/10), $1 \mathrm{~mL} / \mathrm{min}$

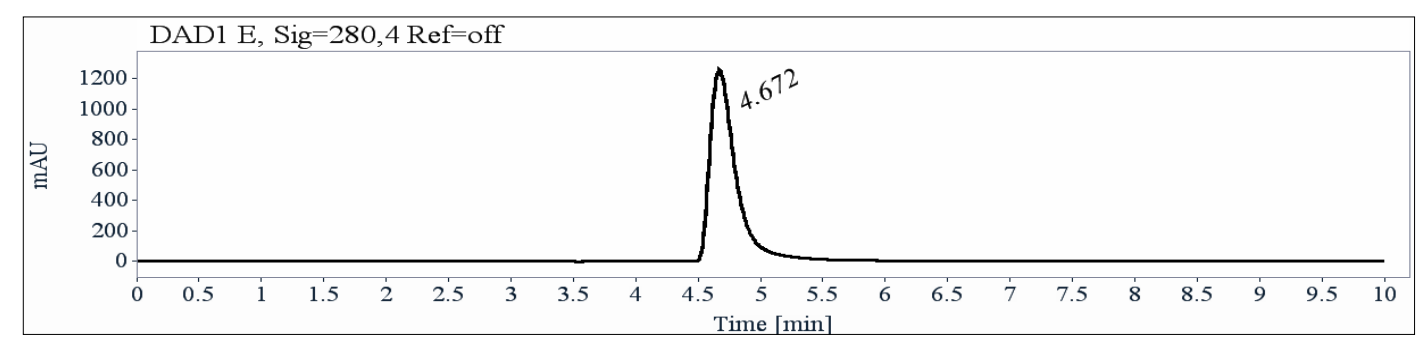

Signal: $\quad$ DAD1 $E$, Sig $=280,4$ Ref $=$ off

\begin{tabular}{|c|c|c|c|c|c|}
\hline RT [min] & Area & Area\% & Capacity Factor & Enantioselectivity & Resolution (USP) \\
\hline 4.67 & 18470 & 100.00 & 0.58 & & \\
\hline Sum & 18470 & 100.00 & & & \\
\hline
\end{tabular}

Sample name: $\quad \mathrm{R}-\left[\mathrm{Cu}\left(\mathrm{BINap}-\mathrm{SQ}_{2}\right)\right]$

Column: Chiralpak IE

Temperature: 10 degres

Mobile phase: Heptane/dichloromethane (90/10), $1 \mathrm{~mL} / \mathrm{min}$ 


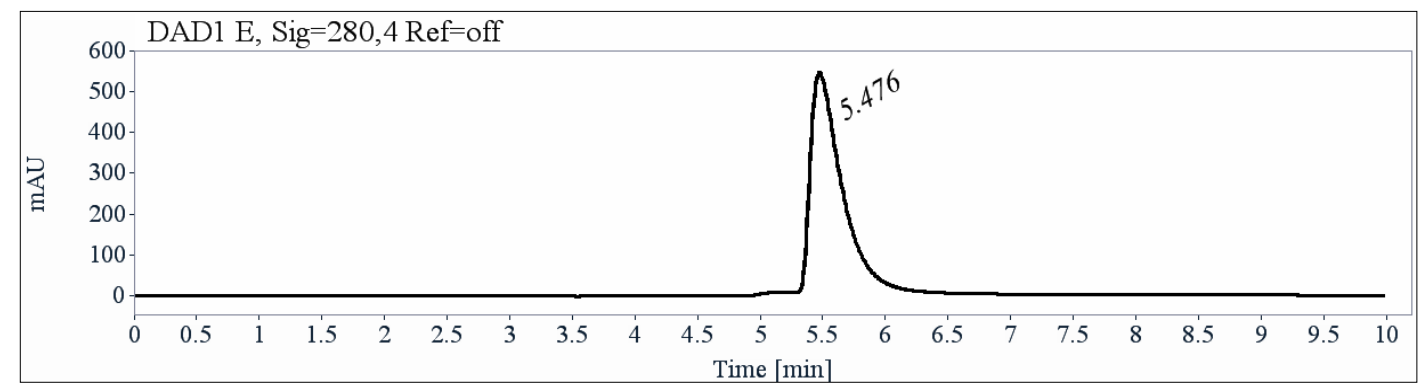

Signal: $\quad$ DAD1 $E$, Sig=280,4 Ref=off

\begin{tabular}{|c|c|c|c|c|c|}
\hline RT [min] & Area & Area\% & Capacity Factor & Enantioselectivity & Resolution (USP) \\
\hline 5.48 & 9944 & 100.00 & 0.86 & & \\
\hline Sum & 9944 & 100.00 & & & \\
\hline
\end{tabular}

\section{Cyclic voltammetry and redox potentials of [Cu(BINap-SQ 2$)] 3$}

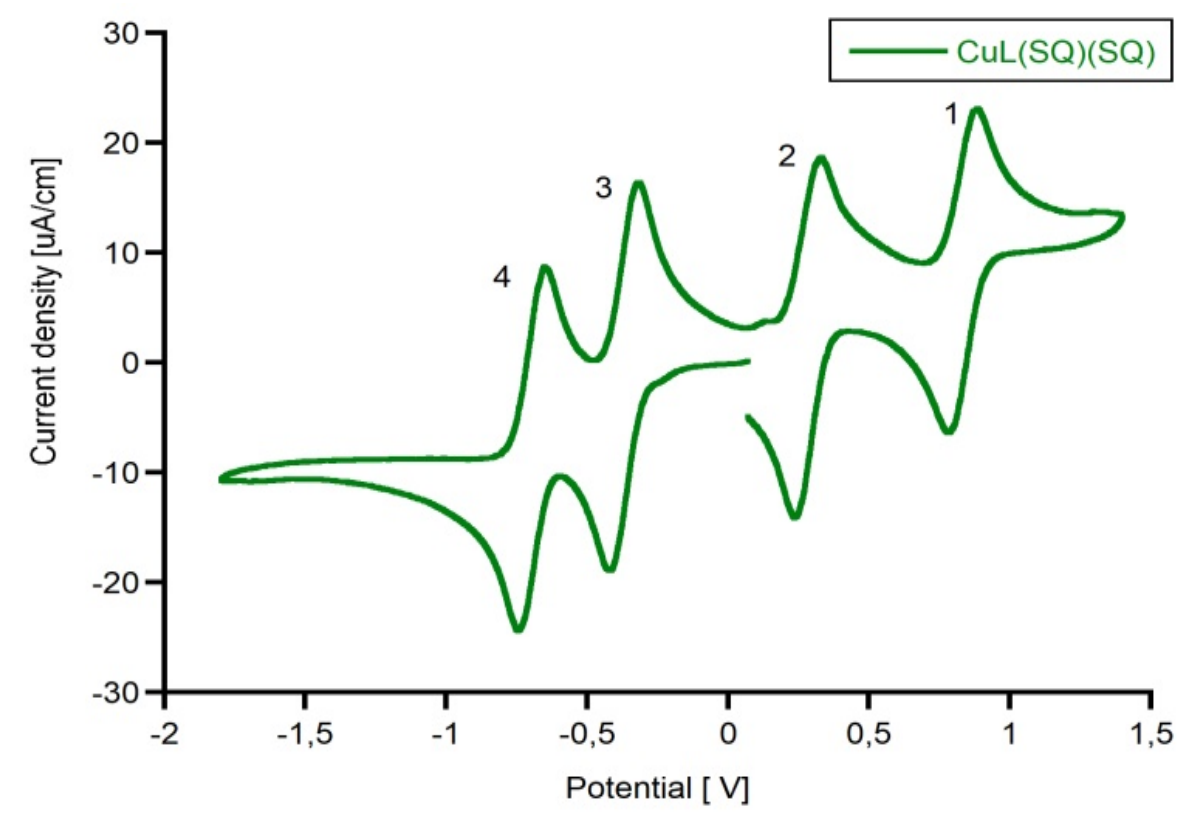

Figure SI-5: Cyclic voltammogram of $\left[\mathrm{Cu}\left(\mathrm{BINap}_{\mathrm{N}} \mathrm{SQ}_{2}\right)\right]\left(\mathrm{C}=1.10^{-3} \mathrm{M}\right)$ in a $0.1 \mathrm{M} \mathrm{TBAPF} \mathrm{T}_{6} / \mathrm{CH}_{2} \mathrm{Cl}_{2}$ electrolyte, scan rate: $100 \mathrm{mV} / \mathrm{s}$

Table SI-1. Summary of the redox potentials for the various waves of the CV of [Cu(BINap-SQ 2$)]$

\begin{tabular}{|c|c|c|c|c|}
\hline Wave & $\begin{array}{l}\text { Ep(red) } \\
\text { V/SCE }\end{array}$ & $\begin{array}{l}\mathrm{Ep}(\mathrm{ox}) \\
\mathrm{V} / \mathrm{SCE}\end{array}$ & $E p(o x)-E p(r e d)$ & $\begin{array}{c}1 / 2(E p(o x)+E p(\text { red })) \\
V / S C E\end{array}$ \\
\hline 1 & 0.786 & 0.887 & $101 \mathrm{mV}$ & 0.84 \\
\hline 2 & 0.237 & 0.333 & $96 \mathrm{mV}$ & 0.29 \\
\hline 3 & -0.415 & -0.316 & $99 \mathrm{mV}$ & -0.37 \\
\hline 4 & -0.745 & -0.650 & $95 \mathrm{mV}$ & -0.70 \\
\hline
\end{tabular}


Table SI-2. Comparison of the half wave potentials of $\mathrm{Cu}(\mathrm{SQ})_{2}, \mathrm{Cu}\left(\mathrm{L}_{\mathrm{Biphen}} \mathrm{SQ}_{2}\right)$ and $\mathrm{Cu}\left(\mathrm{BINap}-\mathrm{SQ}_{2}\right)$.

a) $\mathrm{E}_{\mathrm{FC}+/ \mathrm{Fc}}^{\circ}$ taken as $+0.6 \mathrm{~V} / \mathrm{SCE}$ in $\mathrm{DCM} / 0.1 \mathrm{TBAPF}_{6}{ }^{3}$

\begin{tabular}{|c|c|c|c|c|}
\hline & \multicolumn{4}{|c|}{$1 / 2\left(E_{p}{ }^{(o x)}+E_{p}(\right.$ red $\left.)\right) \quad V / S C E^{a}$} \\
\hline Compound & Wave 1 & Wave 2 & Wave 3 & Wave 4 \\
\hline $\mathrm{Cu}(\mathrm{SQ})_{2}$ & 0.97 & 0.34 & -0.42 & -0.72 \\
\hline $\mathrm{Cu}\left(\mathrm{L}_{\text {Biphen }} \mathrm{SQ}_{2}\right)$ & 0.94 & 0.44 & -0.06 & -0.38 \\
\hline $\mathrm{Cu}\left(\mathrm{BINap}-\mathrm{SQ}_{2}\right)$ & 0.84 & 0.29 & -0.37 & -0.70 \\
\hline
\end{tabular}

\section{CW X-band EPR study of [Cu(BINap-SQ 2$)] 3$}

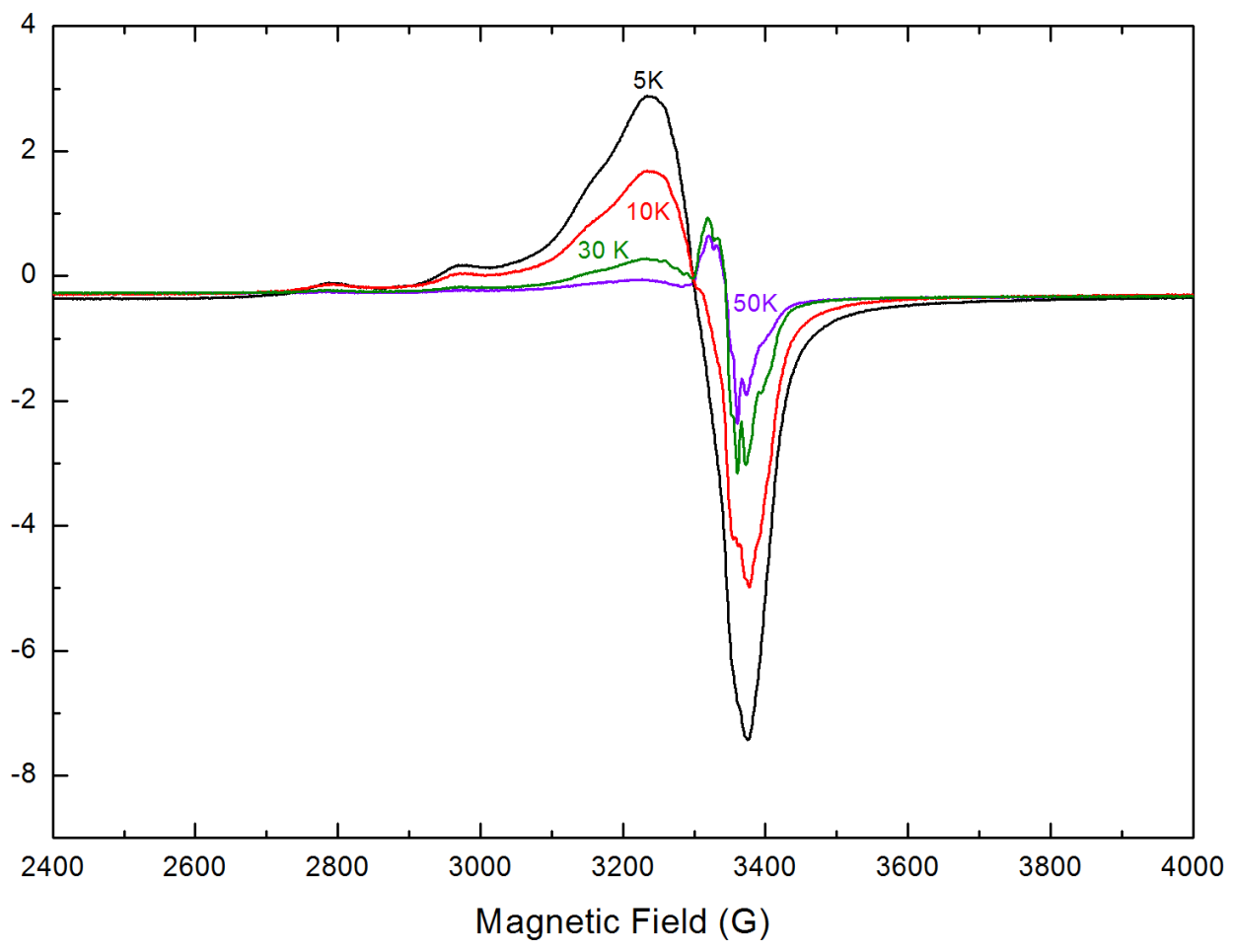

Figure SI-6: Temperature evolution (5K to 50K) of the X-band EPR spectrum of a $1 \mathrm{mM}$, frozen solution of $\left[\mathrm{Cu}\left(\mathrm{BINap}-\mathrm{SQ}_{2}\right)\right]$ in dichloromethane. $v=9.407 \mathrm{GHz}, 5 \mathrm{G}$ amplitude modulation, $0.2 \mathrm{~mW}$ power

The $5 \mathrm{~K}$ spectrum is in agreement with a $\mathrm{Cu}$-based $\mathrm{S}=1 / 2$ ground state (large $\mathrm{g}$ anisotropy). Change of the profile with $\mathrm{T}$ is indicative of the progressive population of excited states, in agreement with a three spin system involving $\mathrm{Cu}(\mathrm{II})$ and two radical ligands.

\footnotetext{
${ }^{3}$ : D. Bao, B. Millare, W. Xia, B. G. Steyer, A. A. Gerasimenko, A. Ferreira, A. Contreras, V. I. Vullev, J. Phys. Chem. A 2009, 113, 1259-1267)
} 
${ }^{1} \mathrm{H}-\mathrm{NMR}$ spectrum of $\left[\mathrm{Cu}\left(\mathrm{BINap}-\mathrm{SQ}_{2}\right)\right] 3$
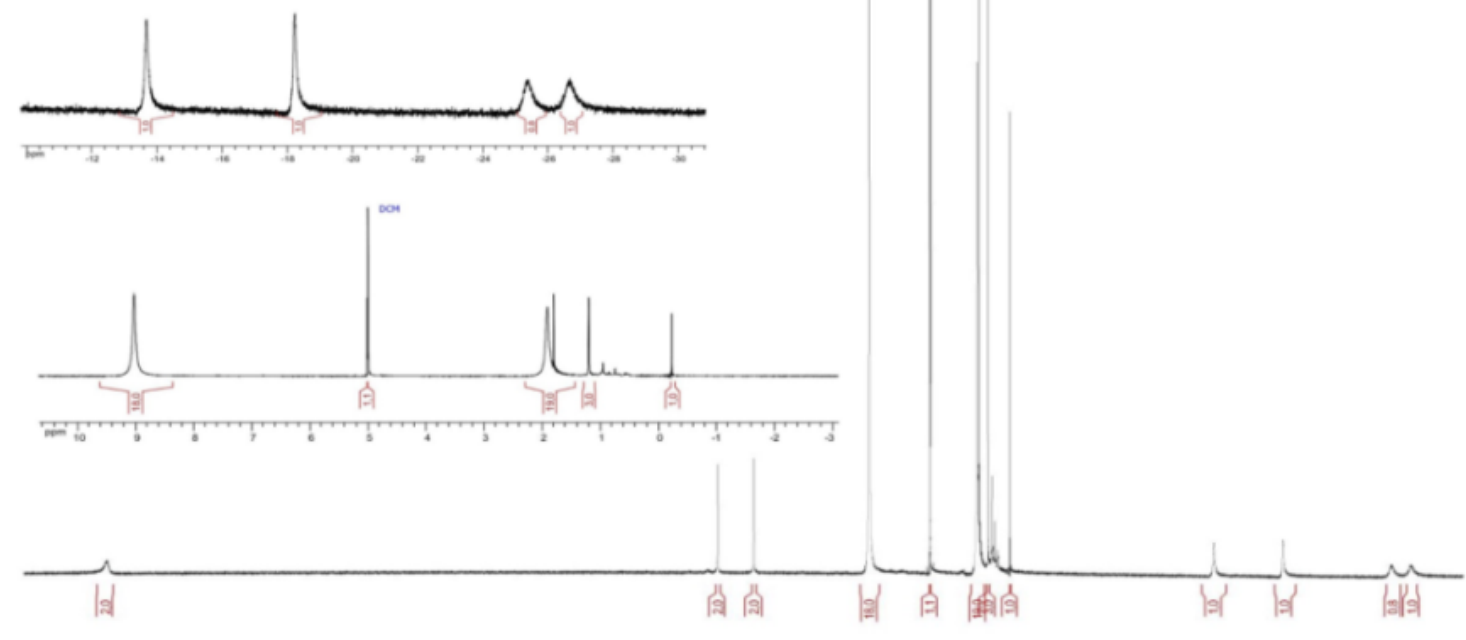

Figure SI-7: Paramagnetic ${ }^{1} \mathrm{H}-\mathrm{NMR}$ spectrum of $\left[\mathrm{Cu}\left(\mathrm{BINap}-\mathrm{SQ}_{2}\right)\right] 3$ 


\section{Synthesis and characterization of $\left[\mathrm{Cu}\left(\mathrm{BINap}-\mathrm{BQ}_{2}\right)\right]^{2+} 5$}

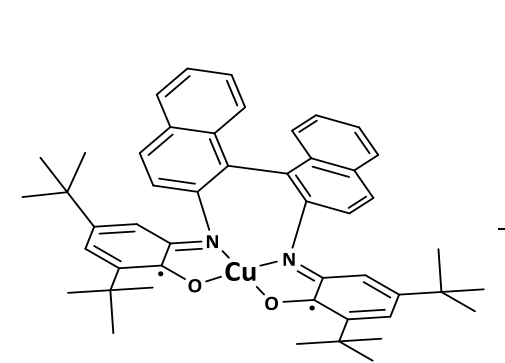

(Rac)-Cu(BINap-SQ $\left.{ }_{2}\right)$
1) 1 equiv. $\mathrm{Br}_{2}$ rt, Ar atmosphere, Dry DCM

2) 2 equiv. $\mathrm{Ag}$ (OTf) rt, Ar atmosphere, Dry $\mathrm{CH}_{3} \mathrm{CN}$ $75 \%$

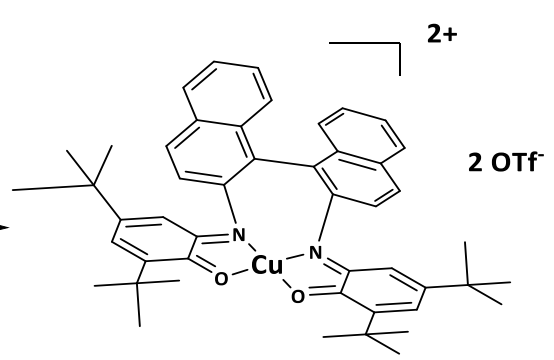

(Rac)-Cu(BINap-BQ $)^{2+}$

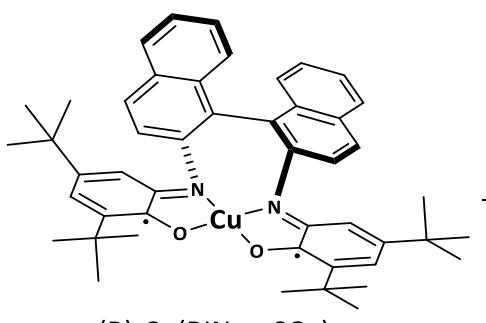

(R)-Cu(BINap-SQ $\left.{ }_{2}\right)$
1) 1 equiv. $\mathrm{Br}_{2}$ rt, Ar atmosphere, Dry DCM

2) 2 equiv. $\mathrm{Ag}(\mathrm{OTf})$ rt, Ar atmosphere, Dry $\mathrm{CH}_{3} \mathrm{CN}$

$70 \%$

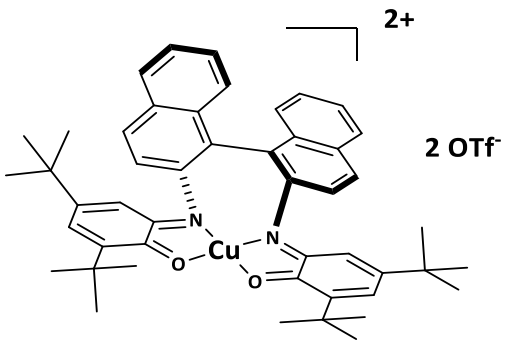

(R)-Cu(BINap-BQ $)^{2+}$

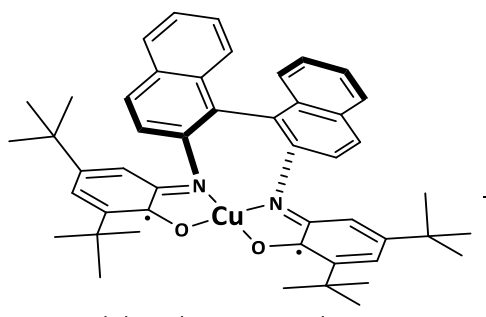

(S)-Cu(BINap-SQ $\left.{ }_{2}\right)$

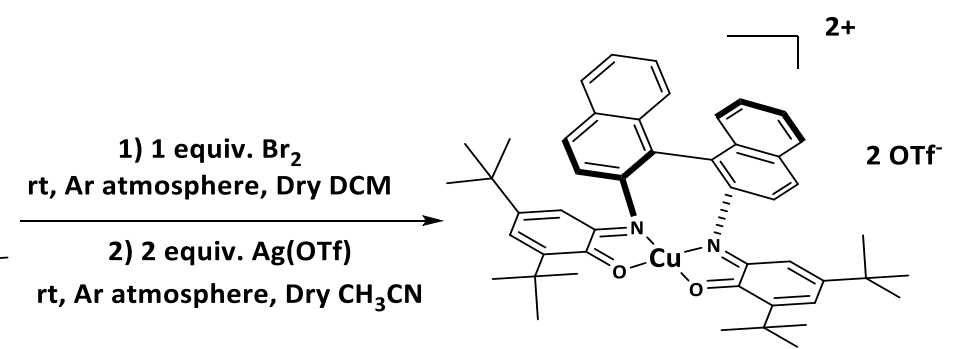

(S)-Cu(BINap-BQ $)^{2+}$

To flame-dried schlenk flask, was introduced [Cu(BINap-SQ 2 )] complex (100 mg, $0.133 \mathrm{mmol}$, 1 equiv.). The flask was back-filled three times with argon and degassed $\mathrm{CH}_{2} \mathrm{Cl}_{2}(5 \mathrm{~mL})$ was added. A 2.8 M solution of bromine in $\mathrm{CH}_{2} \mathrm{Cl}_{2}(47.5 \mu \mathrm{L}, 0.133 \mathrm{mmol}, 1$ equiv.) was added dropwise and the resulting dark-red solution was stirred for $1 \mathrm{~h}$ at room temperature. The solution of silver triflate $(71.8 \mathrm{mg}, 0.28 \mathrm{mmol}, 2$ equiv.) in degassed MeCN was introduced into the schlenk flask under argon atmosphere. The resulting mixture was stirred for 10 minutes at room temperature. The suspension was filtered, and the filtrate was evaporated to a little solution left. Then the solution was added slowly to cold pentane to collect the dark brown precipitation. 


\section{Cyclic voltammetry and redox potentials of $\left[\mathrm{Cu}\left(\mathrm{BINap}-\mathrm{BQ}_{2}\right)\right]^{2+} 5$}

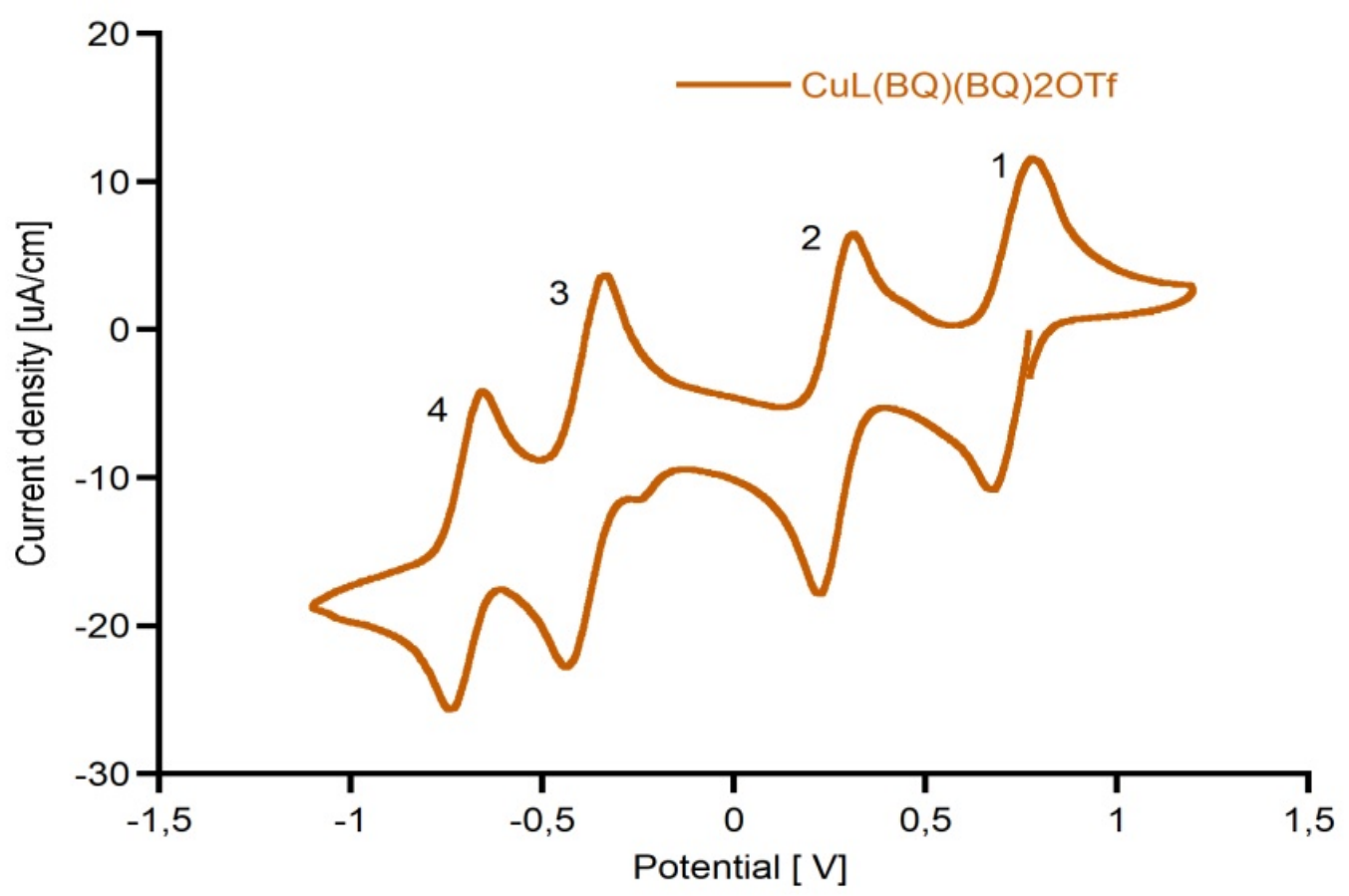

Figure SI-8: $\mathrm{Cyclic}$ voltamogramm of $\left[\mathrm{Cu}\left(\mathrm{BINap}-\mathrm{BQ}_{2}\right)\right]^{2+}\left(\mathrm{C}=1.10^{-3} \mathrm{M}\right)$ in a $0.1 \mathrm{M} \mathrm{TBAPF} / \mathrm{CH}_{2} \mathrm{Cl}_{2}$ electrolyte, scan rate: $100 \mathrm{mV} / \mathrm{s}$

Table SI-3: Summary of the redox potentials for the various waves of the $\mathrm{CV}$ of $\left[\mathrm{Cu}\left(\mathrm{BINap}-\mathrm{BQ}_{2}\right)\right]^{2+}$

\begin{tabular}{|c|c|c|c|c|}
\hline \multirow{3}{*}{ Wave } & $\mathrm{Ep}(\mathrm{red})$ & $\mathrm{Ep}(\mathrm{ox})$ & \multirow{3}{*}{$E p(o x)-E p(r e d)$} & $1 / 2(\operatorname{Ep}(o x)+E p(r e d))$ \\
\hline & & & & \\
\hline & V/SCE & V/SCE & & V/SCE \\
\hline 1 & 0.673 & 0.777 & 104 mV & 0.73 \\
\hline 2 & 0.220 & 0.315 & $95 \mathrm{mV}$ & 0.27 \\
\hline 3 & -0.437 & -0.339 & $98 \mathrm{mV}$ & -0.39 \\
\hline 4 & -0.746 & -0.655 & $91 \mathrm{mV}$ & -0.70 \\
\hline
\end{tabular}


CW X-band EPR study of [Cu(BINap-BQ 2$)]^{2+} 5$

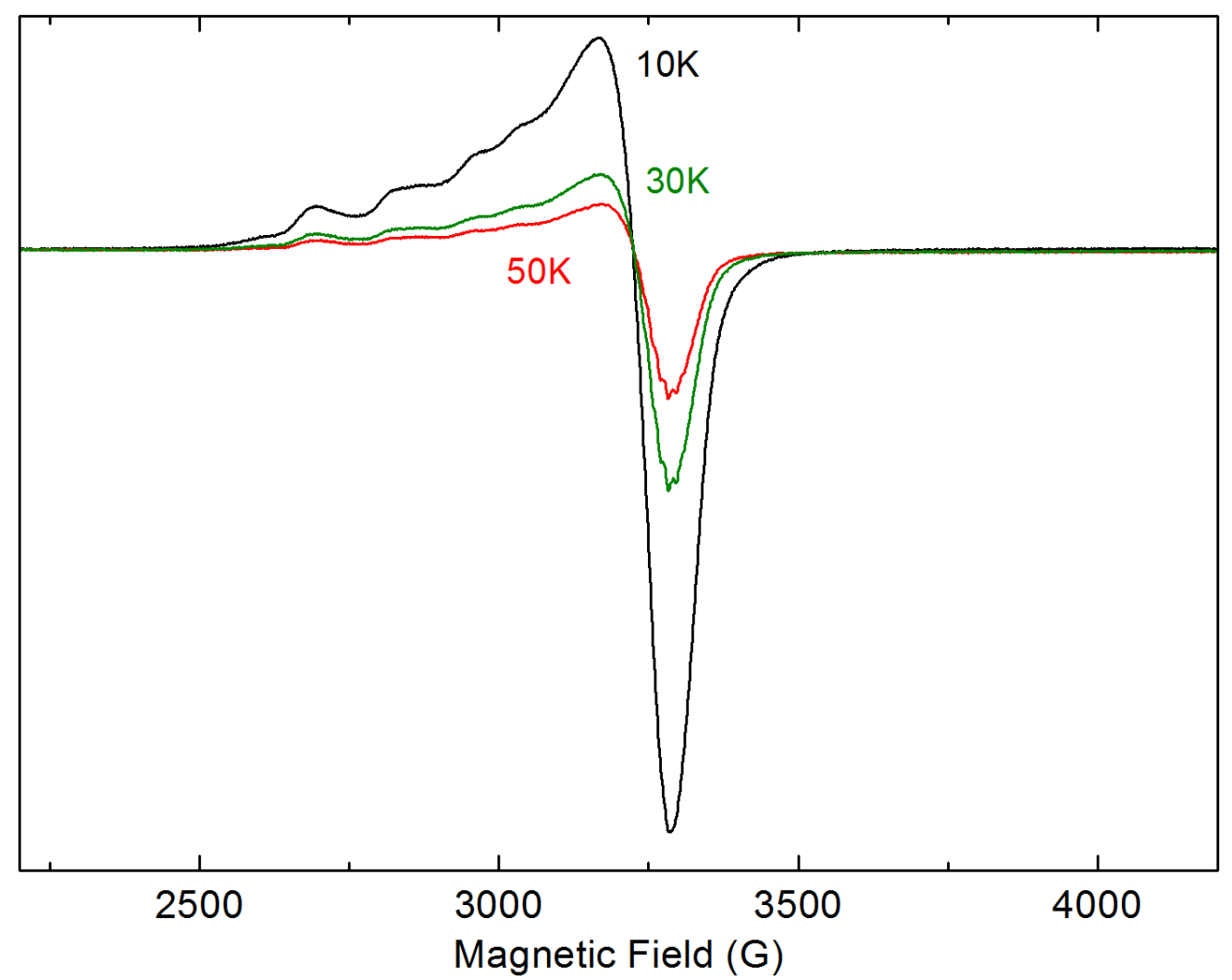

Figure SI-9: Temperature evolution (5K to 50K) of the X-band EPR spectrum of a $1 \mathrm{mM}$ frozen solution of $\left[\mathrm{Cu}\left(\mathrm{BINap}-\mathrm{BQ}_{2}\right)\right]$ in $\mathrm{CH}_{2} \mathrm{Cl}_{2} . \mathrm{v}=9.405 \mathrm{GHz}, 5 \mathrm{G}$ amplitude modulation, $0.04 \mathrm{~mW}$ power

The temperature evolution of the spectrum is classical of the Curie law behavior of a pure $S=1 / 2$ system. The large anisotropy indicates that the spin density is essentially on the copper. 


\section{Synthesis and characterization of [Cu(BINap-SQ-BQ) $]^{+} 1$}

\section{Method A:}

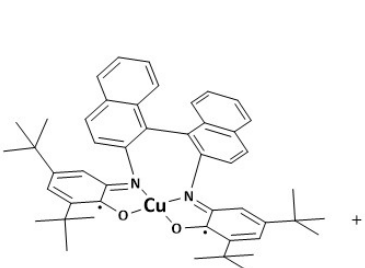

(Rac)-Cu(BINap-SQ ${ }_{2}$ )

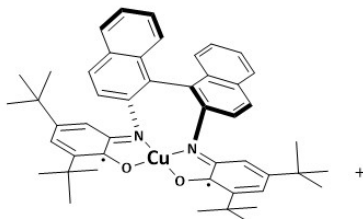

(R)-Cu(BINap-SQ

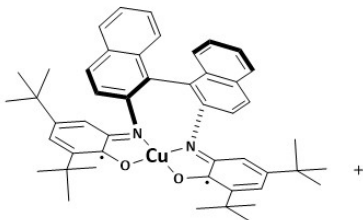

(S)-Cu(BINap-SQ $\left.{ }_{2}\right)$

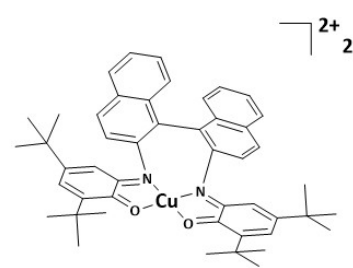

(Rac)-Cu(BINap-BQ $\left.{ }_{2}\right)^{2+}$

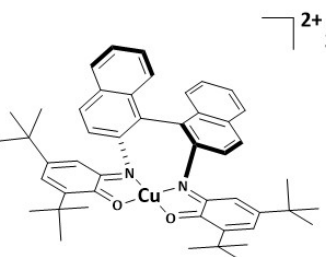

(R)-Cu(BINap- $\left.\mathrm{BO}_{2}\right)^{2+}$

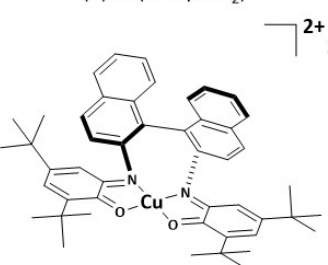

(S)-Cu(BINap-BQ $\left.)_{2}\right)^{2+}$

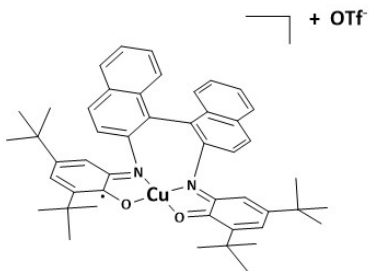

(Rac)-Cu(BINap-SQ-BQ) ${ }^{+}$

$\longrightarrow+$ otf

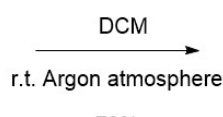

$73 \%$

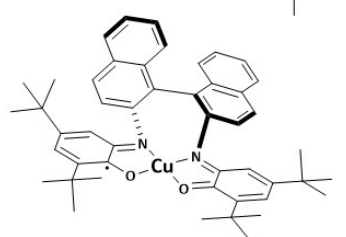

(R)-Cu(BINap-SQ-BQ) + oTf

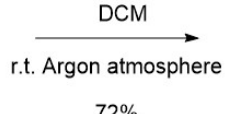

$72 \%$

To a flame-dried schlenk flask, were introduced [Cu(BINap-SQ 2$)$ ] complex (50 mg, $0.066 \mathrm{mmol}, 1$ equiv.) and $\left[\mathrm{Cu}\left(\mathrm{BINap}-\mathrm{BQ}_{2}\right)\right]^{2+}$ complex $(69.8 \mathrm{mg}, 0.066 \mathrm{mmol}, 1$ equiv. $)$. The flask was back-filled three times with argon, degassed $\mathrm{CH}_{2} \mathrm{Cl}_{2}(10 \mathrm{ml})$ was added and the resulting mixture was stirred for $2 \mathrm{~h}$ at room temperature. The solvent was evaporated to give $[\mathrm{Cu}(\mathrm{BINap}-\mathrm{SQ}-\mathrm{BQ})]^{+}$. Then it was washed with cold hexane.

\section{Method B:}

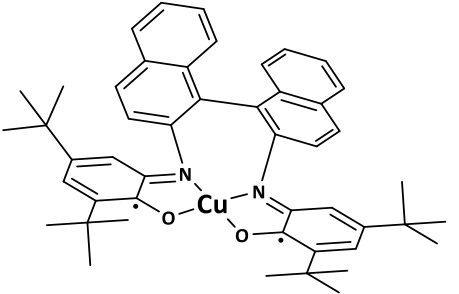

Rac-Cu(BINap-SQ $\left.{ }_{2}\right)$

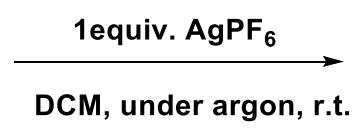

$1 \mathrm{~h}$ $90 \%$

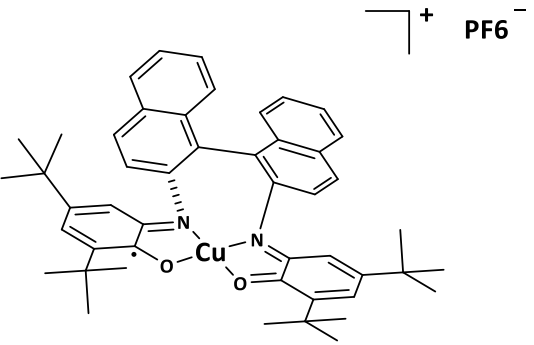

Rac-Cu(BINap-SQ-BQ) ${ }^{+}$

To a flame-dried schlenk flask, were introduced [Cu(BINap-SQ $)$ ]complex (50 mg, 0.066mmol, 1 equiv.) and $\mathrm{AgPF}_{6}(16.8 \mathrm{mg}, 0.066 \mathrm{mmol}, 1$ equiv.). The flask was back-filled three times with argon, degassed $\mathrm{CH}_{2} \mathrm{Cl}_{2}(3 \mathrm{ml})$ was added and the resulting mixture was stirred for $1 \mathrm{~h}$ 
at room temperature. Then the solution was filtered to remove the precipitation. The solvent was evaporated to give $[\mathrm{Cu}(\mathrm{BINap}-\mathrm{SQ}-\mathrm{BQ})]^{+}$. Then it was washed with cold hexane.

HRMS (ESI) calculated for $\mathrm{C}_{48} \mathrm{H}_{52} \mathrm{CuN}_{2} \mathrm{O}_{2} 751.3325$, found [M] ${ }^{+} 751.33$

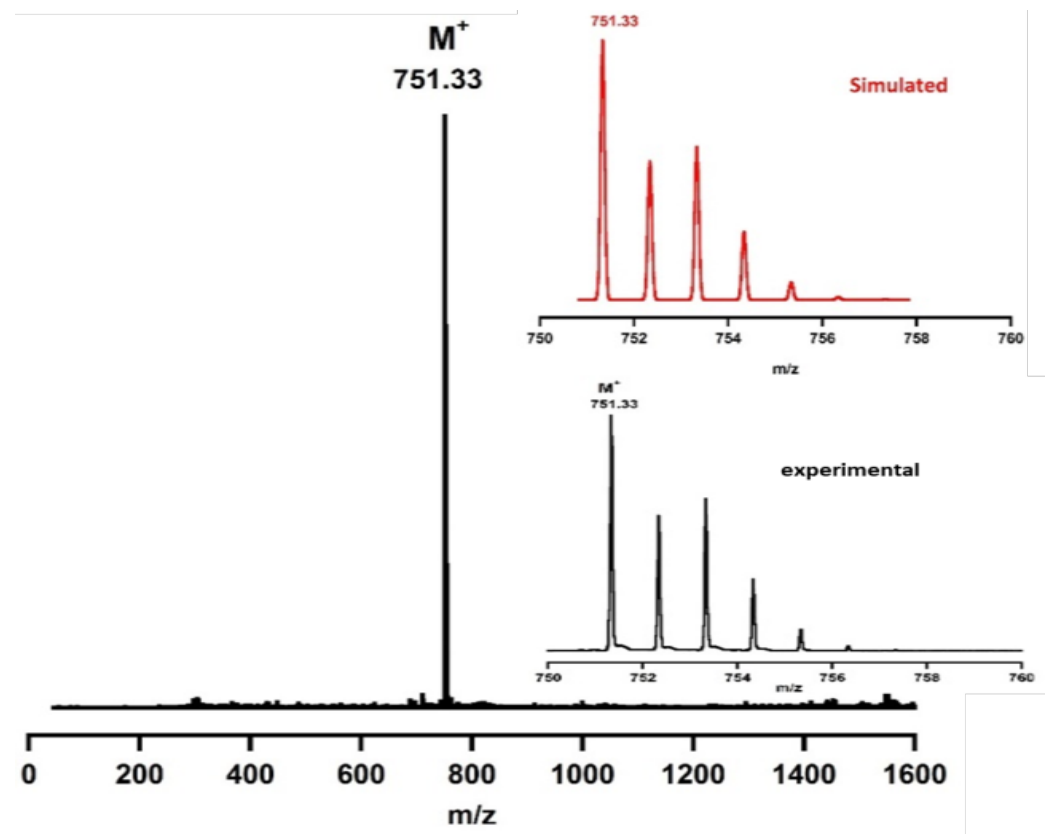

Figure SI-10: The Mass spectrum of [Cu(BINap-SQ-BQ) $]^{+}$

\section{Circular dichroism study of [Cu(BINap-SQ-BQ) $]^{+} 1$}

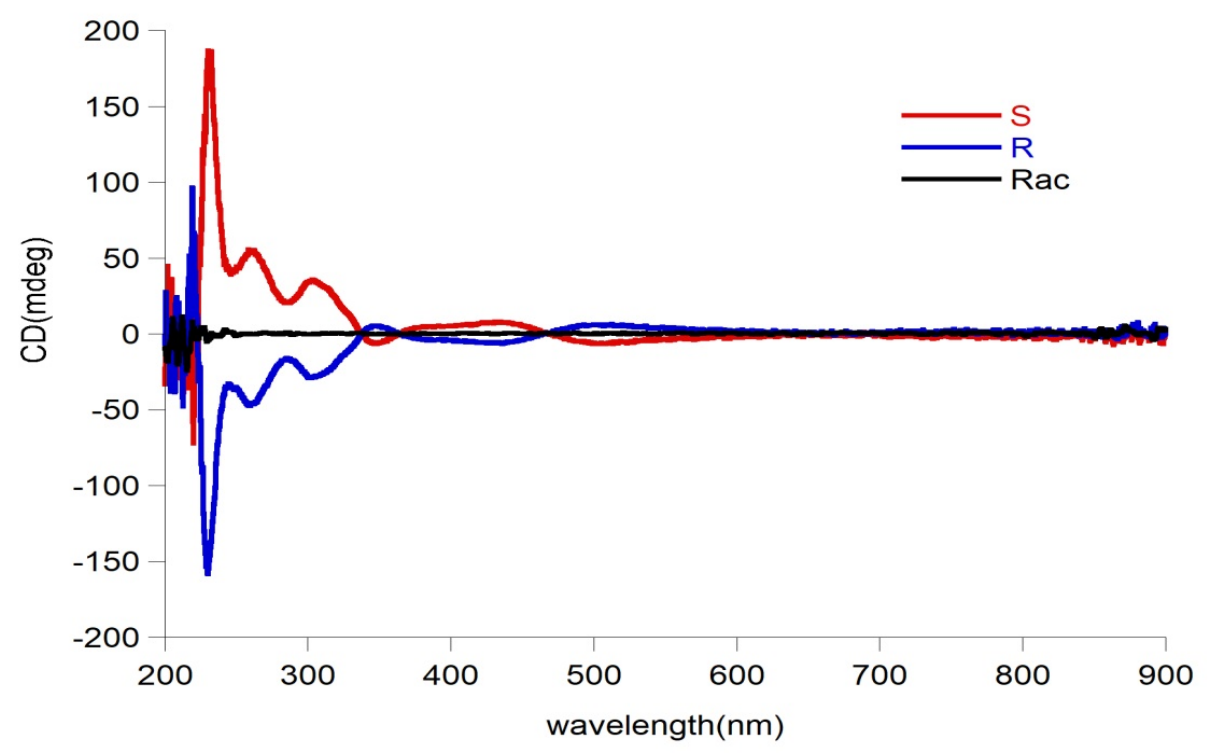

Figure SI-11: Circular Dichroism spectrum of $[\mathrm{Cu}(\mathrm{BINap}-\mathrm{SQ}-\mathrm{BQ})]^{+}(\mathrm{C}=0.3 \mathrm{mM})$ in DCM

$\mathrm{CD}$ spectrum of S-[Cu(BINap-SQ-BQ)$]^{+}$(red line) disclosed a broad positive band with 3 shoulders at (+) 232, 258 and $303 \mathrm{~nm}$. The curve of R-[Cu(BINap-SQ-BQ) $]^{+}$(blue line) has a 
negative band with 3 shoulders at (-) 232, 259, and $304 \mathrm{~nm}$. CD spectrum of Racemate$[\mathrm{Cu}(\mathrm{BINap}-\mathrm{SQ}-\mathrm{BQ})]^{+}$(black line) is silence.

\section{Cyclic voltammetry and redox potentials of [Cu(BINap-SQ-BQ) $]^{+} 1$}

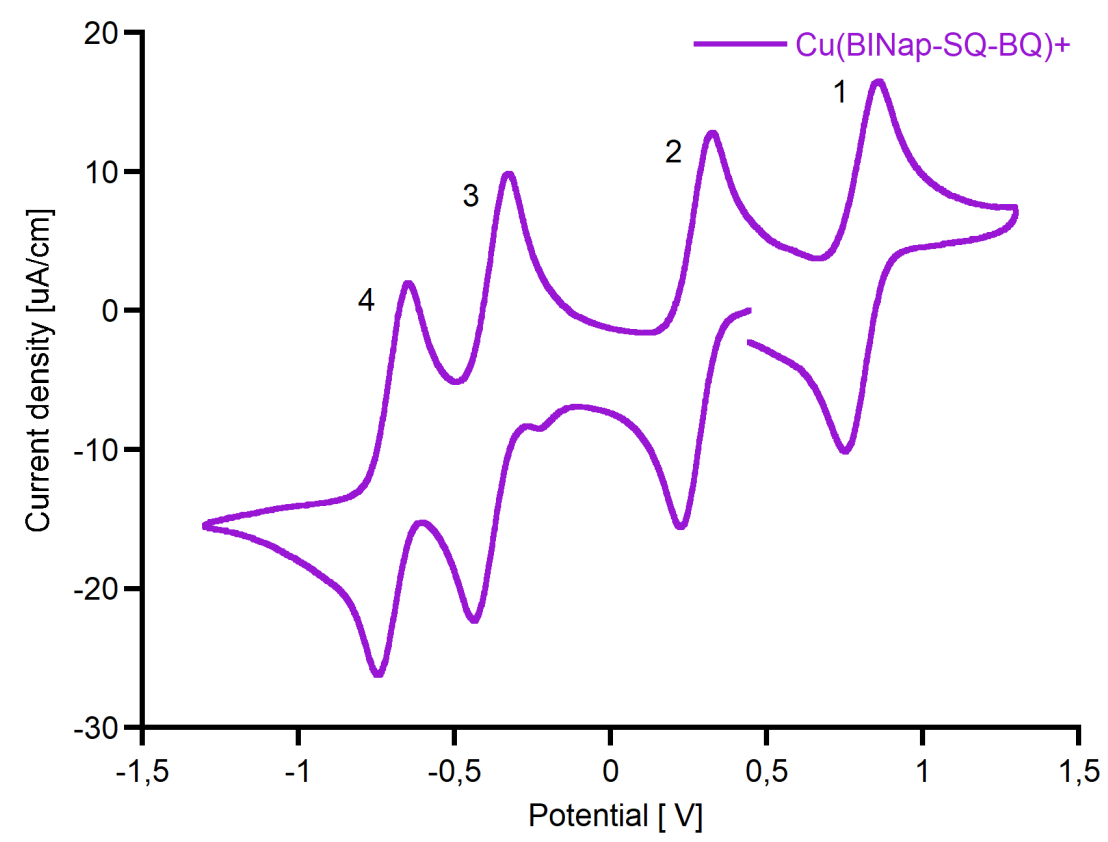

Figure SI-12: Cyclic voltamogramm of [Cu(BINap-SQ-BQ $)]^{+}\left(\mathrm{C}=1.10^{-3} \mathrm{M}\right)$ in a $0.1 \mathrm{M}$ TBAPF $6 \mathrm{CH}_{2} \mathrm{Cl}_{2}$ electrolyte, scan rate: $100 \mathrm{mV} / \mathrm{s}$

Table SI-4: Summary of the redox potentials for the various waves of the CV of [Cu(BINap-SQ-BQ) ${ }^{+}$

\begin{tabular}{ccccc}
\hline Wave & Ep(red) & Ep(ox) & & $1 / 2(E p(o x)+E p(r e d))$ \\
& V/SCE & V/SCE & Ep(ox) - Ep(red) & V/SCE \\
\hline 1 & 0.664 & 0.773 & $109 \mathrm{mV}$ & 0.72 \\
3 & 0.220 & 0.312 & $92 \mathrm{mV}$ & 0.27 \\
4 & -0.443 & -0.342 & $101 \mathrm{mV}$ & -0.39 \\
\hline
\end{tabular}


${ }^{1} \mathrm{H}-\mathrm{NMR}$ spectrum of [Cu(BINap-SQ-BQ $\left.)\right]^{+} 1$

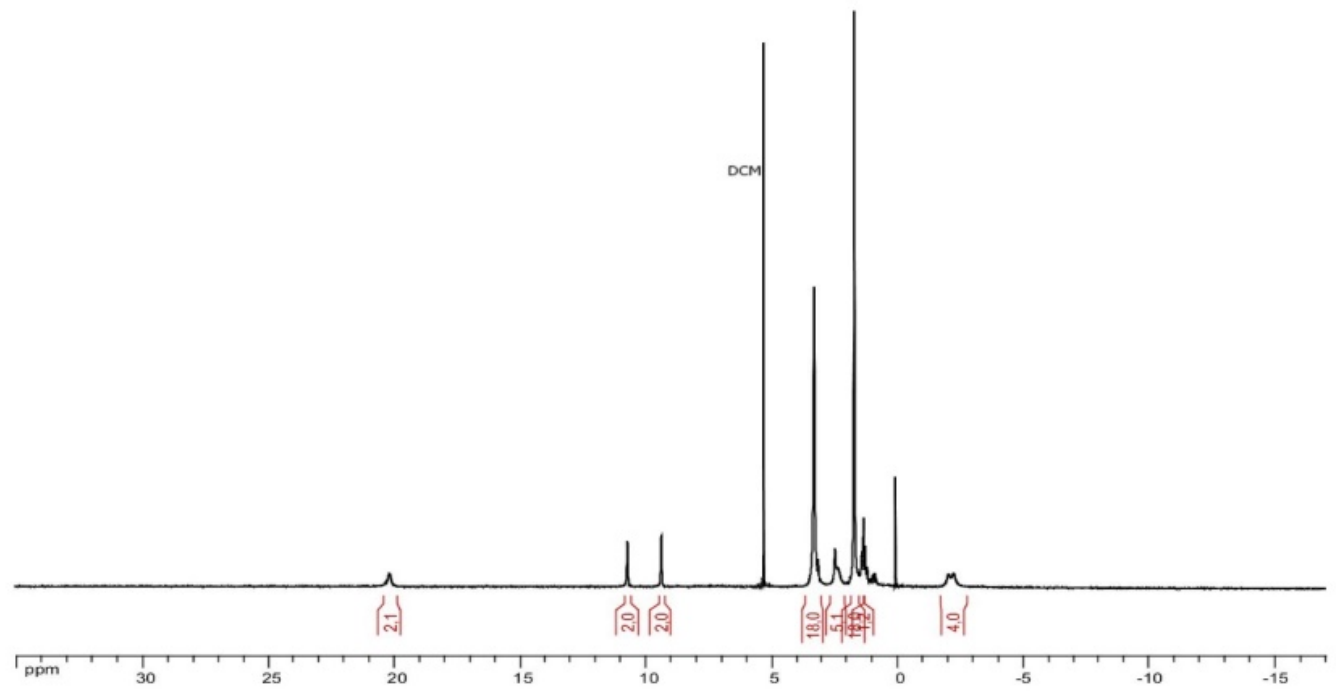

Figure SI-13. ${ }^{1} \mathrm{H}-\mathrm{NMR}$ spectrum of [Cu(BINap-SQ-BQ) $]$ 


\section{X-Ray crystal diffraction studies}

Single crystals of Ligand $\mathbf{2}$ were grown by acetonitrile

Using a mixture of hexane and DCM single crystals of 1 both as a racemate (C2/C space group) and in the pure (S) form (P1 space group) have been obtained.

Attempt to grow crystals of $\mathbf{3}$ by a mixture of acetonitrile and DCM lead to low quality crystals (vide infra).

For complex rac $\mathbf{- 1}$ and ligand $\mathbf{2}$, a single crystal of each compound was selected, mounted onto a cryoloop and transferred into a cold nitrogen gas stream. Intensity data were collected with a Bruker Kappa APEX-II CCD diffractometer using a micro-focused Cu-Ka radiation ( $\lambda=1.54178 \AA$ ). Data collections were performed at $200 \mathrm{~K}$ and $150 \mathrm{~K}$ respectively, with the Bruker APEXIII suite. Unit-cell parameters determinations, integrations and data reductions were carried out with SAINT program. SADABS was used for scaling and absorption corrections. The structures were solved with SHELXT ${ }^{1}$ and refined by full-matrix least-squares methods with SHELXL ${ }^{2}$ using Olex2 software package ${ }^{3}$ or WinGX suite ${ }^{4}$ respectively. All non-hydrogen atoms were refined anisotropically. These structures were deposited at the Cambridge Crystallographic Data Centre with numbers CCDC 1906978 and 1908272 respectively and can be obtained free of charge via www.ccdc.cam.ac.uk.

For complex S-1, a single crystal was selected, mounted onto a cryoloop and transferred into a cold nitrogen gas stream. Intensity data were collected with a Bruker Kappa APEX-II CCD

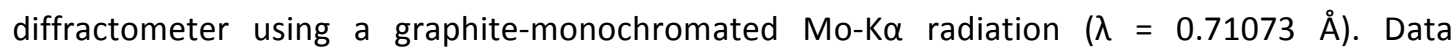
collection was performed at $200 \mathrm{~K}$ with the Bruker APEXII suite. Unit-cell parameters determination, integration and data reduction were carried out with SAINT program. SADABS was used for scaling and absorption correction. The structure was solved with SHELXT ${ }^{1}$ and refined by full-matrix least-squares methods with SHELXL ${ }^{2}$ using Olex2 software package ${ }^{3}$. All non-hydrogen atoms were refined anisotropically. This structure was deposited at the Cambridge Crystallographic Data Centre with number CCDC 1906977 and can be obtained free of charge via www.ccdc.cam.ac.uk. 
Table SI-5. Crystallographic data for compounds $\mathbf{1}$ (racemate and enantiopure form) and $\mathbf{2}$

\begin{tabular}{|c|c|c|c|}
\hline & Complex 1 (racemate) & $\begin{array}{l}\text { Complex } 1 \text { (pure S- } \\
\text { enantiomer) }\end{array}$ & Ligand 2 \\
\hline CCDC number & 1906978 & 1906977 & 1908272 \\
\hline Empirical formula ${ }^{a}$ & $\mathrm{C}_{52} \mathrm{H}_{61} \mathrm{CuF}_{3} \mathrm{~N}_{2} \mathrm{O}_{6} \mathrm{~S}$ & $\mathrm{C}_{52} \mathrm{H}_{61} \mathrm{CuF}_{3} \mathrm{~N}_{2} \mathrm{O}_{6} \mathrm{~S}$ & $\mathrm{C}_{50} \mathrm{H}_{59} \mathrm{~N}_{3} \mathrm{O}_{2}$ \\
\hline \multirow[t]{2}{*}{ Moiety Formula } & $\mathrm{C}_{48} \mathrm{H}_{54} \mathrm{CuN}_{2} \mathrm{O}_{3}{ }^{+}, \mathrm{CF}_{3} \mathrm{O}_{3} \mathrm{~S}^{-}$, & $\mathrm{C}_{48} \mathrm{H}_{54} \mathrm{CuN}_{2} \mathrm{O}_{3}^{+}$ & $\mathrm{C}_{48} \mathrm{H}_{56} \mathrm{~N}_{2} \mathrm{O}_{2}, \mathrm{C}_{2} \mathrm{H}_{3} \mathrm{~N}$ \\
\hline & $0.5\left(\mathrm{C}_{6} \mathrm{H}_{14}\right)$ & $\mathrm{CF}_{3} \mathrm{O}_{3} \mathrm{~S}^{-}, 0.5\left(\mathrm{C}_{6} \mathrm{H}_{14}\right)$ & \\
\hline Formula weight $(\mathrm{g} / \mathrm{mol})$ & 962.62 & 962.62 & 734.00 \\
\hline Temperature (K) & 200 & 200 & 150 \\
\hline Crystal system & Monoclinic & Triclinic & Triclinic \\
\hline Space group & $\mathrm{C} 2 / \mathrm{c}$ & P1 & P-1 \\
\hline a (Å) & $22.1629(4)$ & $13.5427(4)$ & $9.5701(3)$ \\
\hline b (A) & $15.9038(3)$ & $13.6654(5)$ & $14.0551(4)$ \\
\hline c (A) & $30.8951(6)$ & $16.2706(6)$ & $17.8824(6)$ \\
\hline$\alpha\left({ }^{\circ}\right)$ & 90 & $66.046(2)$ & $94.091(2)$ \\
\hline$\beta\left({ }^{\circ}\right)$ & $94.4380(10)$ & $73.780(2)$ & $104.344(2)$ \\
\hline$v\left({ }^{\circ}\right)$ & 90 & $70.417(2)$ & $107.147(2)$ \\
\hline Volume $\left(\AA^{3}\right)$ & $10857.1(4)$ & $2556.49(16)$ & $2199.52(12)$ \\
\hline $\mathbf{Z}$ & 8 & 2 & 2 \\
\hline$\rho_{\text {calc }}\left(g / \mathrm{cm}^{3}\right)$ & 1.178 & 1.251 & 1.108 \\
\hline $\begin{array}{l}\text { Absorption coefficient } \\
\mu\left(\mathrm{mm}^{-1}\right)\end{array}$ & $1.387(\mathrm{CuK} \alpha)$ & $0.527($ MoK $\alpha)$ & $0.515(\mathrm{CuK} \alpha)$ \\
\hline$F(000)$ & 4056 & 1014 & 792 \\
\hline Crystal size $\left(\mathrm{mm}^{2}\right)$ & $0.24 \times 0.10 \times 0.03$ & $0.42 \times 0.11 \times 0.07$ & $0.15 \times 0.10 \times 0.05$ \\
\hline Wavelength $\lambda(\AA)$ & 1.54178 & 0.71073 & 1.54178 \\
\hline $2 \theta$ range $\left({ }^{\circ}\right)$ & $12.528-133.274$ & $3.552-51.56$ & $6.662-133.5$ \\
\hline \multirow[t]{3}{*}{ Miller indexes ranges } & $-26 \leq h \leq 26$ & $-16 \leq h \leq 16$ & $-11 \leq h \leq 11$ \\
\hline & $-17 \leq k \leq 18$ & $-16 \leq k \leq 16$ & $-16 \leq k \leq 16$ \\
\hline & $-36 \leq 1 \leq 36$ & $-19 \leq \mathrm{I} \leq 19$ & $-21 \leq \mathrm{I} \leq 17$ \\
\hline Measured reflections & 42714 & 57248 & 17999 \\
\hline Unique reflections & 9582 & 19327 & 7499 \\
\hline $\mathbf{R}_{\text {int }} / \mathbf{R}_{\text {sigma }}$ & 0.0848 / 0.0943 & 0.0629 / 0.0911 & 0.0406 / 0.0507 \\
\hline Reflections $[I \geq 2 \sigma(I)]$ & 6480 & 13873 & 5945 \\
\hline Restraints & 34 & 44 & 0 \\
\hline Parameters & 628 & 1199 & 499 \\
\hline Goodness-of-fit F² & 1.024 & 1.011 & 1.053 \\
\hline Final $R$ indexes ${ }^{b c}$ [all & $\mathrm{R} 1=0.0984$ & $\mathrm{R} 1=0.0911$ & $\mathrm{R} 1=0.0765$ \\
\hline data] & $w R 2=0.1942$ & $w R 2=0.0965$ & $w R 2=0.1588$ \\
\hline Final $R$ indexes ${ }^{b c}[I \geq$ & $\mathrm{R} 1=0.0625$ & $\mathrm{R} 1=0.0522$ & $\mathrm{R} 1=0.0608$ \\
\hline $2 \sigma(I)]$ & $w R 2=0.1675$ & $w R 2=0.0861$ & $w R 2=0.1498$ \\
\hline $\begin{array}{l}\text { Largest diff. peak/hole } \\
\left(\mathrm{e} / \AA^{3}\right)\end{array}$ & $0.84 /-0.38$ & $0.42 /-049$ & $0.40 /-0.34$ \\
\hline Flack parameter & - & $0.055(5)$ & - \\
\hline
\end{tabular}

${ }^{a}$ Including solvent molecules 
${ }^{\mathrm{b}} R 1=\sum|| F_{o}|-| F_{c}|| / \sum\left|F_{o}\right| \quad{ }^{\mathrm{c}} w R 2=\sqrt{\sum\left(w\left(F_{o}^{2}-F_{c}^{2}\right)\right) / \sum\left(w\left(F_{o}^{2}\right)^{2}\right)}$

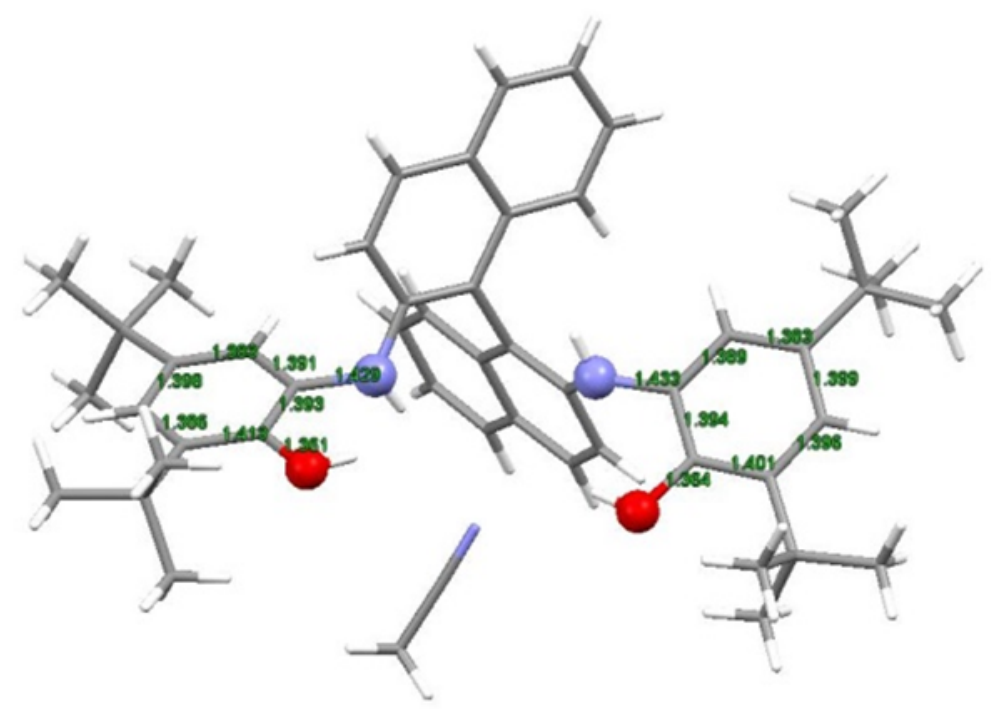

Figure SI-14: Crystal structure of ligand 2. $\mathrm{CH}_{3} \mathrm{CN}$

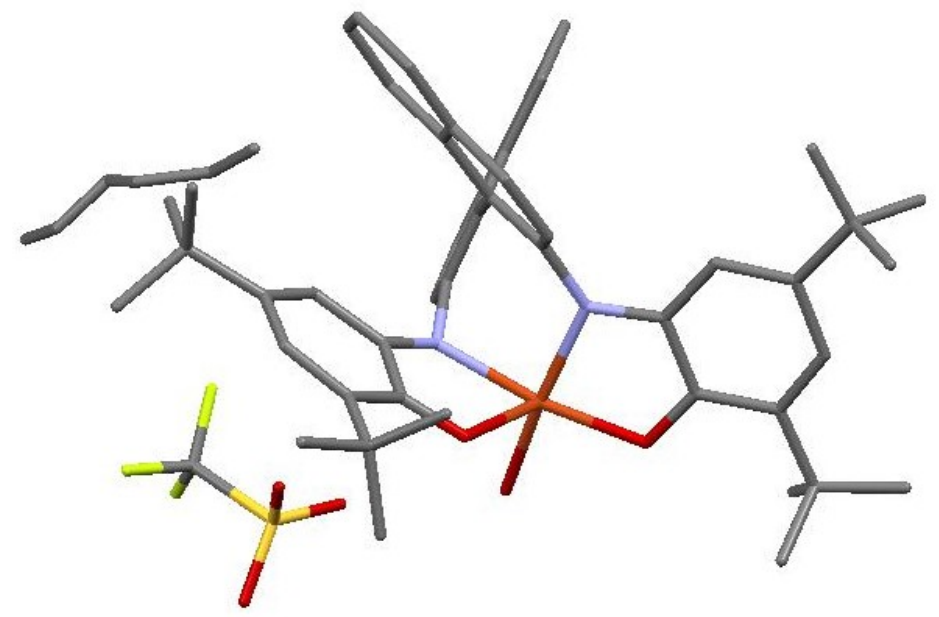

Figure SI-15: Crystal structure of $1 .\left(n-\mathrm{C}_{6} \mathrm{H}_{14}\right)$

N.B. : The geometry (bond distances and angles) of the molecule in the rac-1 crystals and S-1 crystals is almost identical 


\section{Representation of [Cu(BINap-SQ $\left.\left.\mathrm{SQ}_{2}\right)\right]$ obtained from very poorly diffracting crystals}

Despite several recrystallization attempts, diffraction efficiency of the obtained single crystals was very weak. Nevertheless, a single crystal was selected, mounted onto a cryoloop and transferred into a cold nitrogen gas stream. One phi-scan was launched to collect data for unit-cell parameters determination. The measure was performed at 200K with a Bruker Kappa

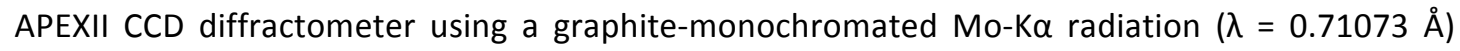
and Bruker APEX2 suite. The $2 \theta$ max value did not exceed $32^{\circ}$. Unit cell determination was carried out with SAINT program. A data integration with SAINT and scaling and absorption correction with SADABS were performed with this incomplete dataset.

Table SI-6. Crystal data for compound [Cu(BINap-SQ 2$)]$ at $200 \mathrm{~K}$

\begin{tabular}{|c|c|}
\hline Crystal system & Triclinic \\
\hline Space group & P-1 \\
\hline a $(\AA ̊)$ & $11.105(18)$ \\
\hline b (Å) & $19.53(3)$ \\
\hline c (Å) & $23.28(4)$ \\
\hline$\alpha\left({ }^{\circ}\right)$ & $104.23(2)$ \\
\hline$\beta\left({ }^{\circ}\right)$ & $98.09(3)$ \\
\hline$\nu\left(^{\circ}\right)$ & $90.15(3)$ \\
\hline Volume $\left(\AA^{3}\right)$ & $4842(14)$ \\
\hline Z & 2 \\
\hline
\end{tabular}

$2 \theta$ range for unit cell data collection was $2.152-31.858^{\circ}$.

The structure was solved by SHELXT ${ }^{1}$ but could not be refined because of the incomplete and poor quality dataset.(maximum resolution: 1.29 Angströms).

It gave access to the connectivity between atoms.

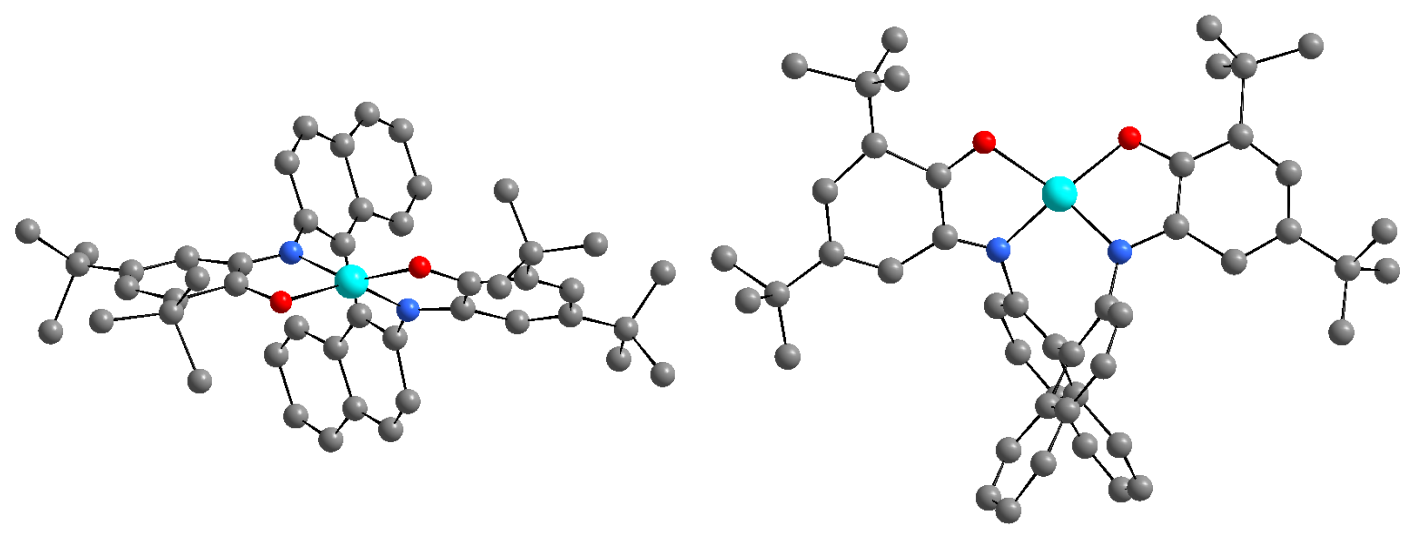

Figure SI-16: ball and stick representation of [Cu(BINap-SQ 2$)]$ 
Optimization condition of aziridination and enantiomeric excess measurement

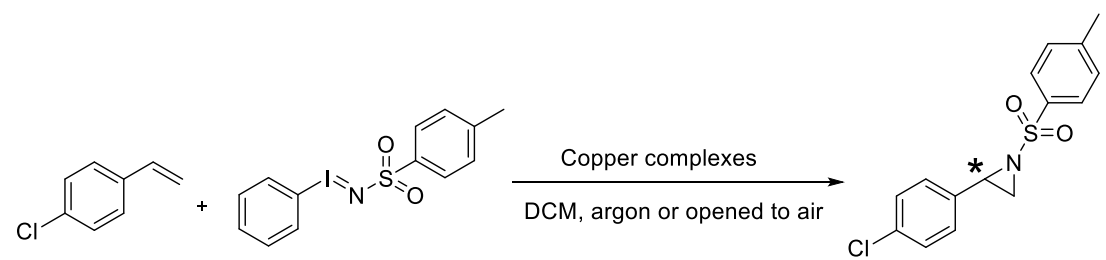

Table SI-7: Influence of the dilution

\begin{tabular}{ccccccc}
\hline Entry & complex & $\begin{array}{c}\text { Temp. } \\
\left({ }^{\circ} \mathrm{C}\right)\end{array}$ & Time & Solvent & Yield & E.e \\
\hline 1 & $\mathrm{~S}-\mathrm{Cu}(\mathrm{BINap}-\mathrm{SQ}-\mathrm{BQ})^{+}(1 \%)$ & 20 & $50 \mathrm{~min}$ & $\mathrm{DCM}(0.4 \mathrm{~mL})$ & $>99 \%$ & $4 \%$ \\
2 & $\mathrm{~S}-\mathrm{Cu}(\mathrm{BINap}-\mathrm{SQ}-\mathrm{BQ})^{+}(1 \%)$ & 20 & $15 \mathrm{~min}$ & $\mathrm{DCM}(10 \mathrm{~mL})$ & $>99 \%$ & $17 \%$ \\
3 & $\mathrm{~S}-\mathrm{Cu}(\mathrm{BINap}-\mathrm{SQ}-\mathrm{BQ})^{+}(1 \%)$ & 20 & $30 \mathrm{~min}$ & $\mathrm{DCM}(20 \mathrm{~mL})$ & $97 \%$ & $22 \%$ \\
4 & $\mathrm{~S}-\mathrm{Cu}(\mathrm{BINap}-\mathrm{SQ}-\mathrm{BQ})^{+}(1 \%)$ & 20 & $30 \mathrm{~min}$ & $\mathrm{DCM}(30 \mathrm{~mL})$ & $>99 \%$ & $17 \%$ \\
5 & $\mathrm{~S}-\mathrm{Cu}(\mathrm{BINap}-\mathrm{SQ}-\mathrm{BQ})^{+}(1 \%)$ & 20 & $30 \mathrm{~min}$ & $\mathrm{DCM}(40 \mathrm{~mL})$ & $87 \%$ & $21 \%$ \\
\hline
\end{tabular}

Table SI-8: Influence of the temperature and the amount of copper complex

\begin{tabular}{ccccccc}
\hline Entry & complex & ${\text { Temp. }\left({ }^{\circ} \mathrm{C}\right)}$ & Time & Solvent & Yield & E.e \\
\hline 1 & $\mathrm{~S}-\mathrm{Cu}(\mathrm{BINap}-\mathrm{SQ}-\mathrm{BQ})^{+}(1 \%)$ & 20 & $30 \mathrm{~min}$ & $\operatorname{DCM}(20 \mathrm{~mL})$ & $>99 \%$ & $22 \%$ \\
2 & $\mathrm{~S}-\mathrm{Cu}(\mathrm{BINap}-\mathrm{SQ}-\mathrm{BQ})^{+}(1 \%)$ & 0 & $20 \mathrm{~h}$ & $\operatorname{DCM}(20 \mathrm{~mL})$ & $56 \%$ & $28 \%$ \\
3 & $\mathrm{~S}-\mathrm{Cu}(\mathrm{BINap}-\mathrm{SQ}-\mathrm{BQ})^{+}(3 \%)$ & 0 & $1 \mathrm{~h}$ & $\operatorname{DCM}(20 \mathrm{ml})$ & $99 \%$ & $35 \%$ \\
4 & $\mathrm{~S}-\mathrm{Cu}(\mathrm{BINap}-\mathrm{SQ}-\mathrm{BQ})^{+}(3 \%)$ & -20 & $2 \mathrm{~h}$ & $\operatorname{DCM}(20 \mathrm{ml})$ & $70 \%$ & $34 \%$ \\
4 & $\mathrm{~S}-\mathrm{Cu}(\mathrm{BINap}-\mathrm{SQ}-\mathrm{BQ})^{+}(5 \%)$ & 0 & $1 \mathrm{~h}$ & $\operatorname{DCM}(20 \mathrm{ml})$ & $99 \%$ & $33 \%$ \\
\hline
\end{tabular}

HPLC (Chiralcel OJ; $1.0 \mathrm{ml} / \mathrm{min}$; i-PrOH/n-hexane 30:70; $\lambda=254 \mathrm{~nm})^{4}$

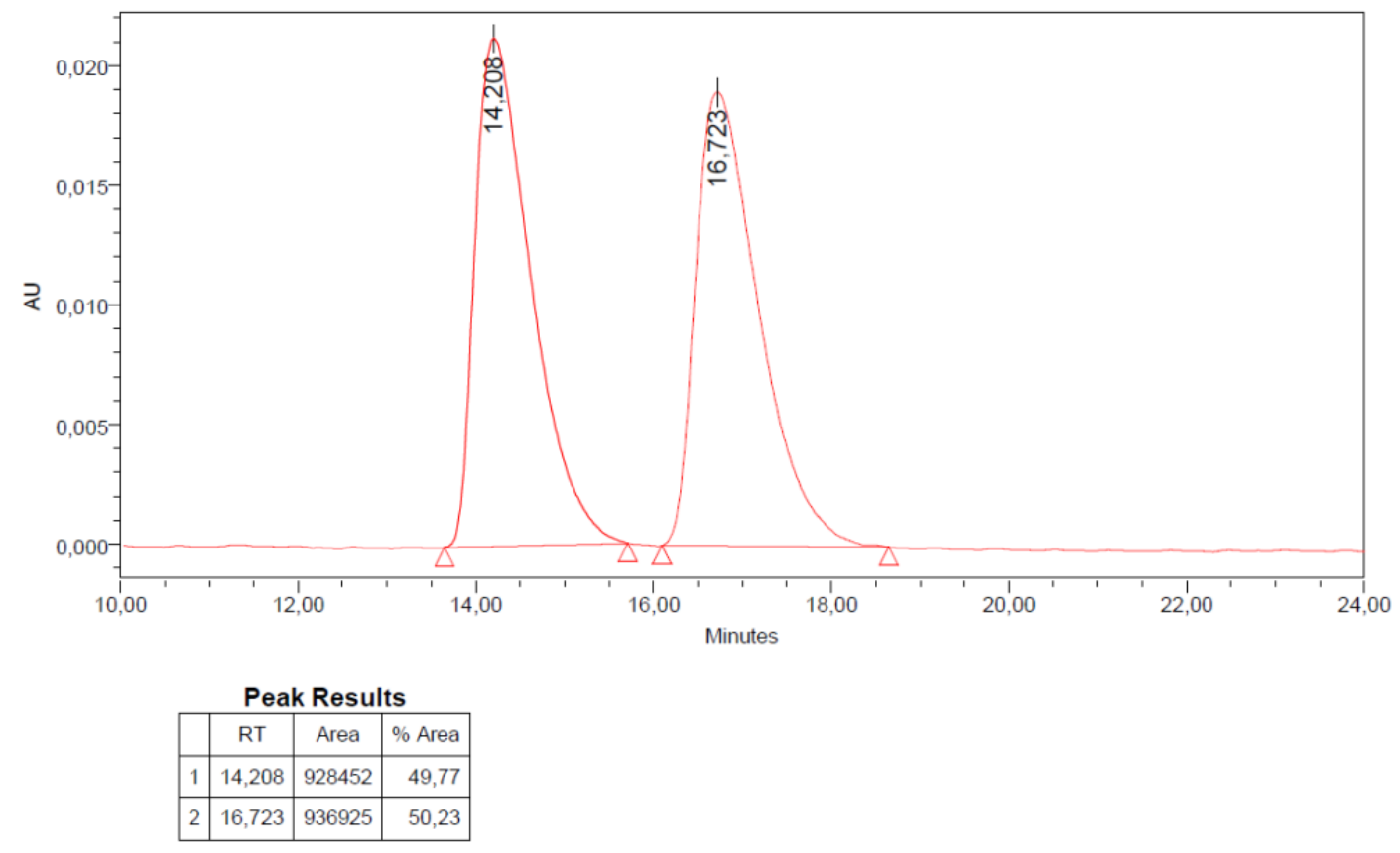

\footnotetext{
${ }^{4}$ Y. Takeda, Y. Ikeda, A Kuroda, S Tanaka, and S Minakata, J. Am. Chem. Soc. 2014, 136, 24, 8544-8547.
} 


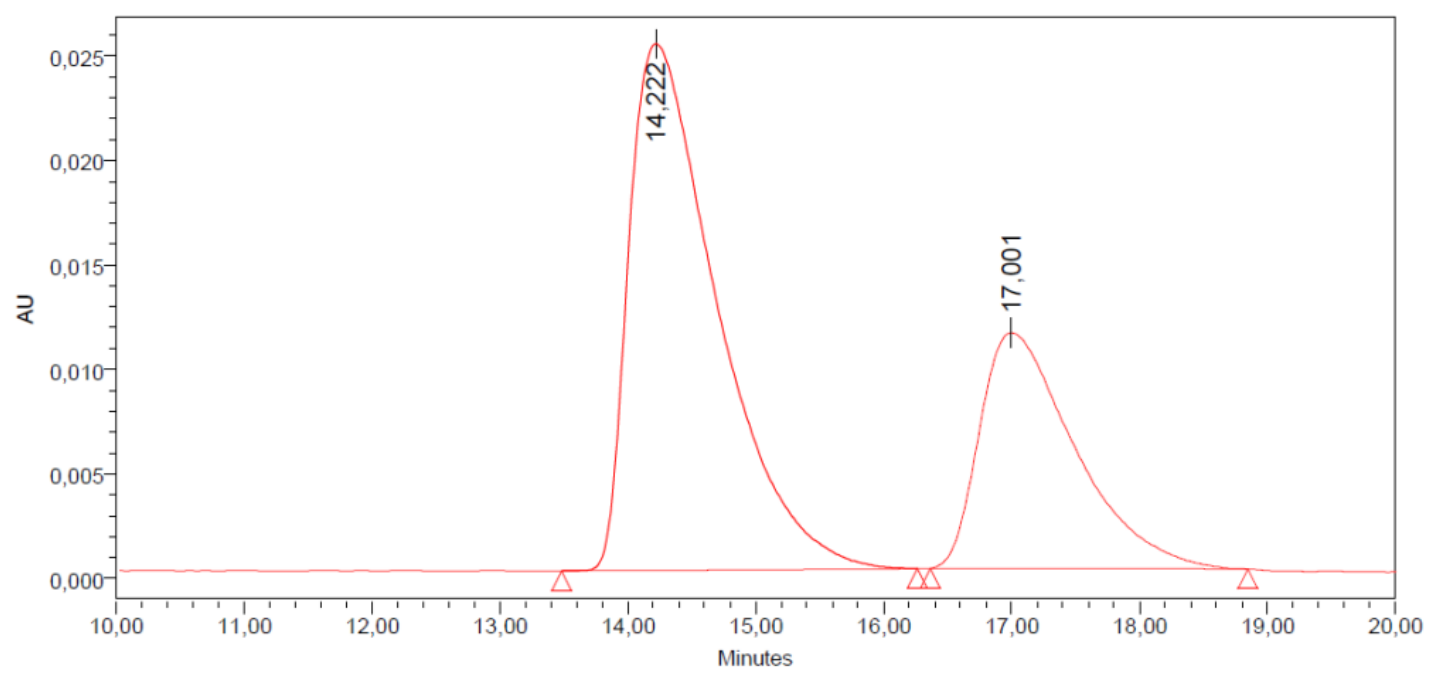

Peak Results

\begin{tabular}{|c|c|c|r|}
\hline & RT & Area & $\%$ Area \\
\hline 1 & 14,222 & 1206566 & 67,43 \\
\hline 2 & 17,001 & 582837 & 32,57 \\
\hline
\end{tabular}




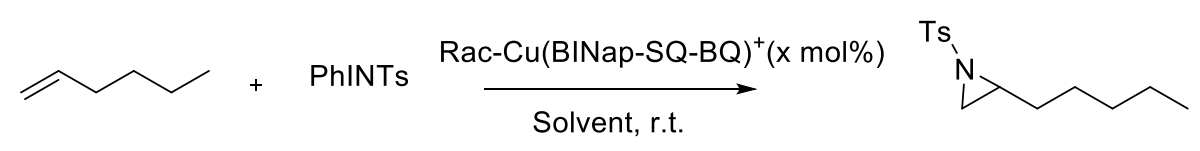

Table SI-9: Optimization study for the aziridination of 1-hexene

\begin{tabular}{lcclll}
\hline Entry & $\begin{array}{c}\text { [Cu(BINap-SQ-BQ) }^{+} \\
\text {X mol\% }\end{array}$ & $\begin{array}{c}\text { Styrene/PhINTs } \\
\text { (equiv./equiv.) }\end{array}$ & Slovent & T & Yield \\
\hline 1 & $1 \mathrm{~mol} \%$ & $4 / 1$ & $\operatorname{DCM}(10 \mathrm{ml})$ & $6 \mathrm{~h}$ & $29 \%$ \\
2 & $3 \mathrm{~mol} \%$ & $4 / 1$ & $\operatorname{DCM}(10 \mathrm{ml})$ & $6 \mathrm{~h}$ & $38 \%$ \\
3 & $3 \mathrm{~mol} \%$ & $4 / 1$ & $\operatorname{DCM}(0.4 \mathrm{ml})$ & $7 \mathrm{~h}$ & $40 \%$ \\
5 & $5 \mathrm{~mol} \%$ & $4 / 1$ & $\operatorname{DCM}(10 \mathrm{ml})$ & $35 \mathrm{~min}$ & $47 \%$ \\
4 & $1 \mathrm{~mol} \%$ & $4 / 1$ & $\operatorname{MeCN}(0.4 \mathrm{~mL})$ & $24 \mathrm{~h}$ & $71 \%$ \\
6 & $5 \mathrm{~mol} \%$ & $4 / 1$ & $\operatorname{MeCN}(10 \mathrm{ml})$ & $30 \mathrm{~min}$ & $62 \%$ \\
7 & $5 \mathrm{~mol} \%$ & $1 / 2$ & $\operatorname{MeCN}(0.4 \mathrm{ml})$ & $2 \mathrm{~h}$ & $80 \%$ \\
\hline
\end{tabular}

\section{Representative procedure for the aziridination}

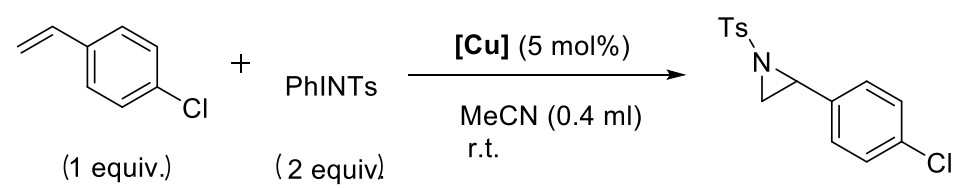

In a Schlenk flask (under argon or opened to air) were introduced copper complex (0.025 mmol, 5 mol\%), 4-chlorostyrene (63 $\mu \mathrm{L}, 0.5 \mathrm{mmol}, 1$ equiv.) and $\mathrm{MeCN}(400 \mu \mathrm{L})$. The nitrene source PhINTs was then added (373 mg, $1 \mathrm{mmol}, 2$ equiv.) and the reaction mixture was stirred for $2 \mathrm{~min}$ at room temperature. The reaction was quenched with a saturated $\mathrm{NH}_{4} \mathrm{Cl}$ aqueous solution and the aqueous phase was extracted with $\mathrm{CH}_{2} \mathrm{Cl}_{2}$. The combined organic layers were washed with brine, dried over $\mathrm{Na}_{2} \mathrm{SO}_{4}$, filtered and concentrated under vacuum. Purification by silica gel column chromatography (elution: pentane/dichloromethane) afforded the final product as a white powder.

${ }^{1} \mathrm{H}$ NMR yields were determined using trimethoxybenzene as internal standard and calculated considering styrene as limiting reactant. 


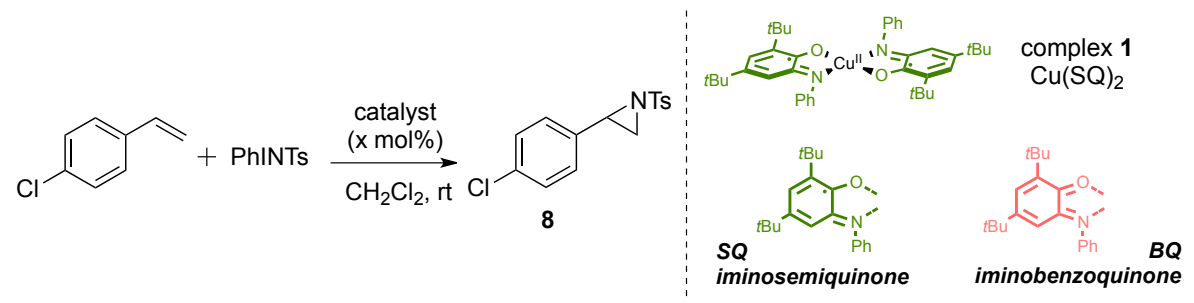

Table SI-10. Reactivity of strained (2, 4 and $\mathbf{5})$ and unstrained $(\mathbf{1}, \mathbf{6}$ and $\mathbf{7})$ complexes in aziridination of 4-chlorostyrene.

\begin{tabular}{lllllll}
\hline entry $^{\text {[a] }}$ & 1 & 2 & 3 & 4 & 5 & 6 \\
\hline Redox state & SQ/SQ & & SQ/BQ & & BQ/BQ & \\
Ligand & $\mathrm{L}_{2}$ & BINap & $\mathrm{L}_{2}$ & BINap & $\mathrm{L}_{2}$ & BINap \\
Complex & $\mathbf{1}$ & $\mathbf{4}$ & $\mathbf{6}$ & $\mathbf{2}$ & $\mathbf{7}$ & $\mathbf{5}$ \\
Yield (\%) & 52 & 11 & 19 & $>99$ & 20 & 74 \\
\hline
\end{tabular}

[a] Reaction conditions: 4-chlorostyrene (4 equiv.), PhINTs (1 equiv.), complex (3 mol\%), DCM, $0^{\circ} \mathrm{C}, 1 \mathrm{~h}$. Yields were determined by ${ }^{1} \mathrm{H}$ NMR using trimethoxybenzene as internal standard and calculated considering nitrene source as limiting reactant. 


\section{N-tosyliminobenzyliodinane synthesis}<smiles>Cc1ccc(S(=O)(=O)N=Ic2ccccc2)cc1</smiles>

To a stirred solution of tosylamide $(1.71 \mathrm{~g}, 10 \mathrm{mmol}, 1$ equiv.) in methanol $(40 \mathrm{~mL})$ was added portionwise, at $0{ }^{\circ} \mathrm{C}, \mathrm{KOH}(1.40 \mathrm{~g}, 25 \mathrm{mmol}, 2.5$ equiv.). After complete dissolution of $\mathrm{KOH}$, iodobenzene diacetate $(3.22 \mathrm{~g}, 10 \mathrm{mmol}, 1$ equiv.) was added. The reaction mixture was stirred for $3 \mathrm{~h}$ at room temperature and then poured into ice water. After $4 \mathrm{~h}$, the suspension was filtered and the resulting solid was washed with cold methanol, to afford PhINTs as a yellow pale solid $(1.21 \mathrm{~g}, 33 \%)$. The characterization data were identical to those previously reported. ${ }^{5}$

${ }^{1} \mathrm{H}$ NMR $\left(\mathrm{d}_{6}-\mathrm{DMSO}, 400 \mathrm{MHz}\right) \delta 2.27(\mathrm{~s}, 3 \mathrm{H}),, 7.06(\mathrm{~d}, J=7.9 \mathrm{~Hz}, 2 \mathrm{H}), 7.29(\mathrm{t}, J=7.7 \mathrm{~Hz}, 2 \mathrm{H})$, 7.40-7.50 (m, 3H), $7.69(\mathrm{~d}, J=7.8 \mathrm{~Hz}, 2 \mathrm{H})$.

${ }^{13} \mathrm{C}$ NMR ( $\mathrm{d}_{6}$-DMSO, $\left.101 \mathrm{MHz}\right) \delta 20.9,117.2,126.1,128.6,130.2,130.5,133.2,140.1,142.2$

\footnotetext{
${ }^{5}$ A. Yoshimura, M. W. Luedtke, V. V. Zhdankin, J. Org. Chem. 2012, 77, 2087-2091.
} 
Mechanistic studies of aziridination by mass spectrometry, UV-vis and ${ }^{1} \mathrm{H}$ NMR spectroscopies

\section{Mass spectrometry}

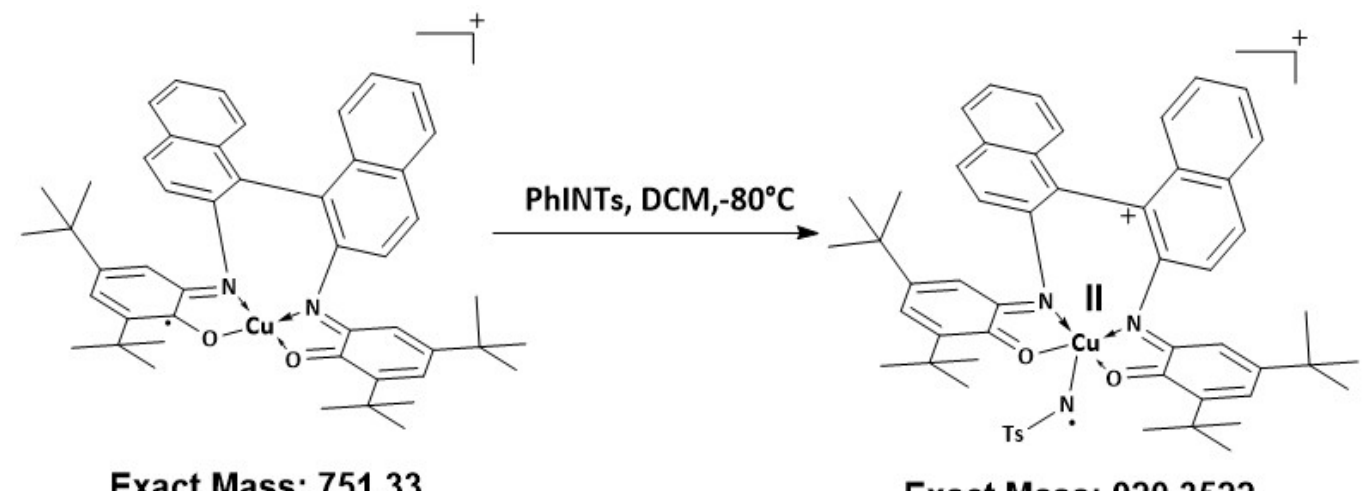

Exact Mass: 751,33

Exact Mass: 920.3522

Proposed structures for reactive intermediate

Protocol: To a solution of [Cu(BINap-SQ-BQ) $]^{+} 2$ in DCM $(0.2 \mathrm{mg} / 2 \mathrm{ml})$ kept at $-80{ }^{\circ} \mathrm{C}$, PhINTs (10 mg) was added. After $20 \mathrm{~min}$, the solution was filtered quickly and diluted 2 times at $-80^{\circ} \mathrm{C}$ and quickly injected in the mass spectrometer.

A control experiment was performed at room temperature. The same solution of $[\mathrm{Cu}(\mathrm{BINap}-\mathrm{SQ}-\mathrm{BQ})]^{+} 2$ was prepared and PhINTs $(10 \mathrm{mg})$ was added at room temperature. The color of the solution changed from green to yellow very quickly. The solution was filtered quickly, diluted 2 times and and quickly injected in the mass spectrometer. 

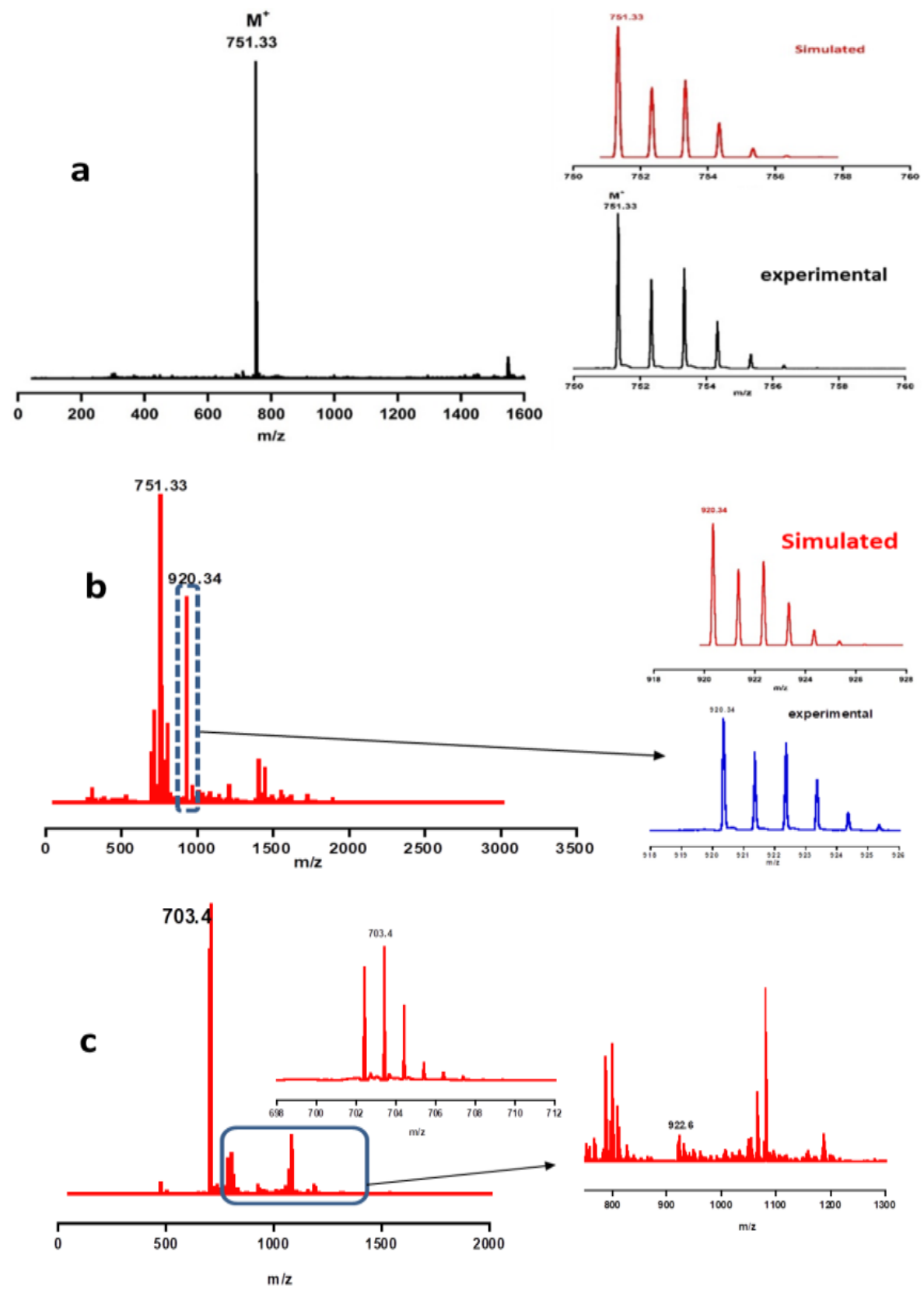

Figure SI-17: (a) Original mass spectrum of [Cu(BINap-SQ-BQ) $]^{+} \mathbf{1}$ and after addition of PhINTs at (b) $-80^{\circ} \mathrm{C}$, (c) rt. 


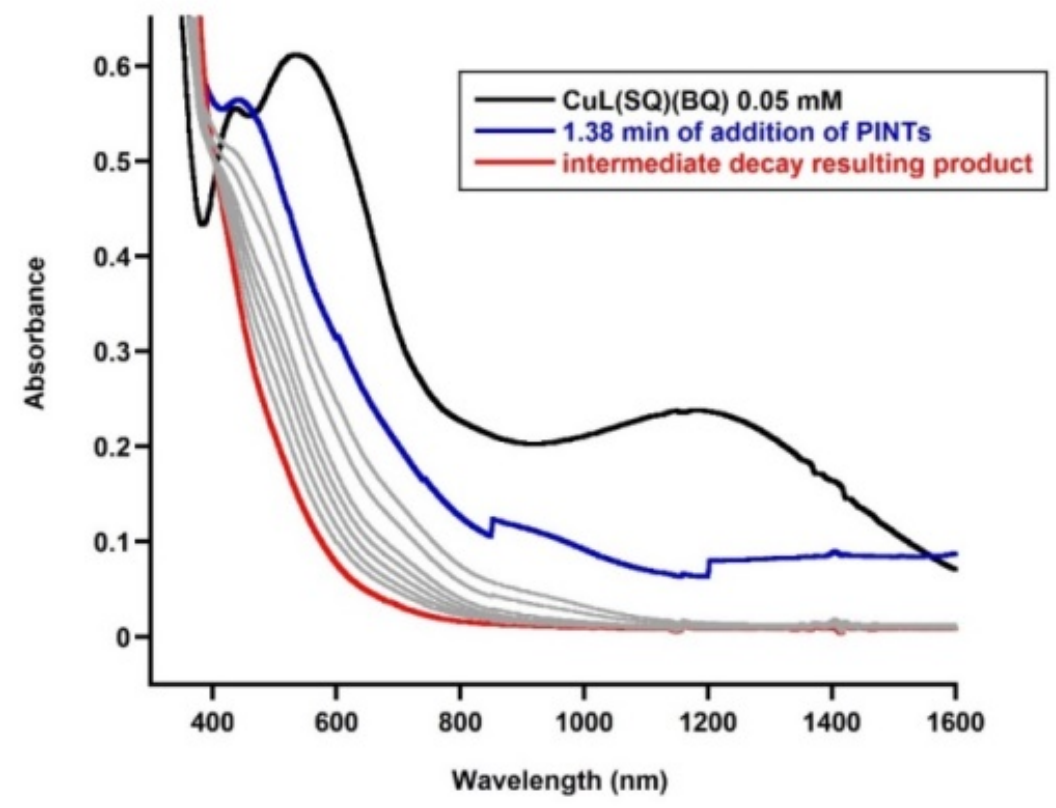

Figure SI-18: Evolution of the reaction (0.05 mM of [Cu(BINap-SQ-BQ) $]^{+} \mathbf{1}+1$ equiv. of PhINTs) monitored by UV-Vis-NIR spectroscopy in distilled DCM at $0^{\circ} \mathrm{C}$ under argon atmosphere. Black trace: initial spectrum $\mathrm{Cu}(\mathrm{BINap}-\mathrm{SQ}-\mathrm{BQ})^{+}$. Blue trace: $1.38 \mathrm{~min}$ after addition of PhINTs. Red trace: final decay of the intermediate.

\section{${ }^{1} \mathrm{H}$ NMR kinetic studies}
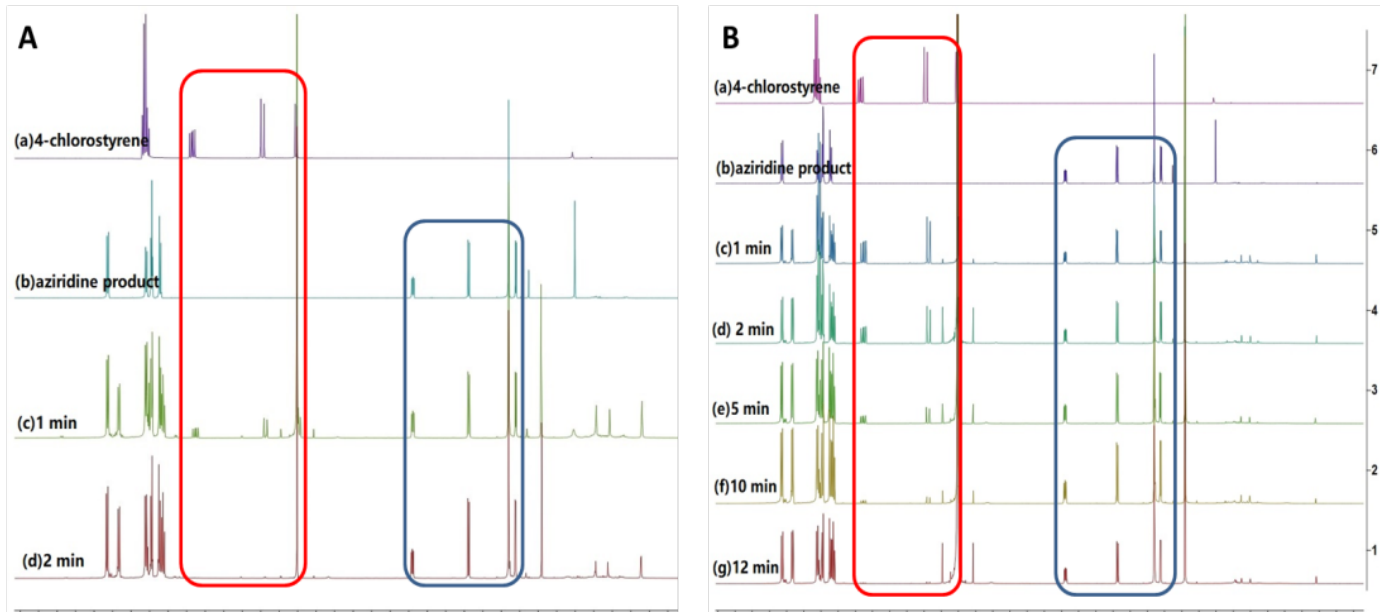

$\begin{array}{llllllllllllllllllllll}9.0 & 8.5 & 8.0 & 7.5 & 7.0 & 6.5 & 6.0 & 5.5 & 5.0 & 4.5 & 4.0 & 3.5 & 3.0 & 2.5 & 2.0 & 1.5 & 1.0 & 0.5\end{array}$

$\begin{array}{llllllllllllllllllllll}8.5 & 8.0 & 7.5 & 7.0 & 6.5 & 6.0 & 6.5 & 5.0 & 4.5 & 4.0 & 3.5 & 3.0 & 2.5 & 2.0 & 1.5 & 1.0 & 0.5 & 0.0 & 0.5\end{array}$

Figure SI-19: ${ }^{1} \mathrm{H}$ NMR kinetic study of the aziridination reaction catalyzed by: A) complex $\mathrm{Cu}(\mathrm{BINap}-\mathrm{SQ}-\mathrm{BQ})^{+} \mathbf{1}$, and $\left.\mathrm{B}\right) \mathrm{Cu}(\mathrm{SQ})_{2}$. Reaction conditions: 4-chlorostyrene (1 equiv.), PhINTs (2 equiv.), copper complex (5 mol\%), acetonitrile, rt. 


\section{Optimization condition of cyclopropanation reaction}

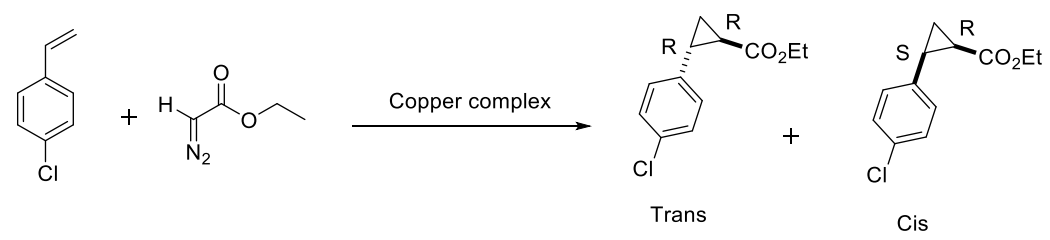

Table SI-11: The influence of the amount of copper complex

\begin{tabular}{cccccccc}
\hline \multirow{2}{*}{ Entry } & complex & $\begin{array}{c}\text { Styrene/EDA } \\
\text { (equiv./equiv.) }\end{array}$ & Slovent & Temp. & T & Yield & Trans/Cis \\
\hline 1 & S-Cu(BINap-SQ-BQ) (1\%) & $2 / 1$ & DCM & 20 & $2 \mathrm{~h}$ & $86 \%$ & $1.26: 1$ \\
2 & S-Cu(BINap-SQ-BQ) (0.5\%) & $2 / 1$ & DCM & 20 & $2 \mathrm{~h}$ & $59 \%$ & $1.27: 1$ \\
3 & S-Cu(BINap-SQ-BQ) (2\%) & $2 / 1$ & DCM & 20 & $2 \mathrm{~h}$ & $83 \%$ & $1.06: 1$ \\
\hline
\end{tabular}

Table SI-12: The influence of the concentration of substrates and reaction time

\begin{tabular}{cccccccc}
\hline \multirow{2}{*}{ Entry } & complex & $\begin{array}{c}\text { Styrene/EDA } \\
\text { (equiv./equiv.) }\end{array}$ & Slovent & Temp. & T & Yield & Trans/Cis \\
\hline 1 & S-Cu(BINap-SQ-BQ) (1\%) & $2 / 1$ & DCM & 20 & $2 \mathrm{~h}$ & $86 \%$ & $1.26: 1$ \\
2 & S-Cu(BINap-SQ-BQ) (1\%) & $1 / 2$ & DCM & 20 & $2 \mathrm{~h}$ & $99 \%$ & $1.25: 1$ \\
3 & S-Cu(BINap-SQ-BQ) (1\%) & $1 / 2$ & DCM & 20 & $20 \mathrm{~min}$ & $99 \%$ & $1.25: 1$ \\
\hline
\end{tabular}

Table SI-13: The influence of different of solvent

\begin{tabular}{ccccccccc}
\hline \multirow{2}{*}{ Entry } & complex & $\begin{array}{c}\text { Styrene/EDA } \\
\text { (equiv./equiv.) }\end{array}$ & Slovent & Temp. & T & Yield & Trans/Cis \\
\hline 1 & S-Cu(BINap-SQ-BQ) (1\%) & $1 / 2$ & DCM & 20 & $2 \mathrm{~h}$ & $99 \%$ & $1.25: 1$ \\
2 & S-Cu(BINap-SQ-BQ) (1\%) & $1 / 2$ & Toluene & 20 & $2 \mathrm{~h}$ & $40 \%$ & $1: 1$ \\
3 & S-Cu(BINap-SQ-BQ) (1\%) & $1 / 2$ & $\mathrm{MeCN}$ & 20 & $2 \mathrm{~h}$ & $29 \%$ & $1: 1.12$ \\
4 & $\mathrm{~S}-\mathrm{Cu}(\mathrm{BINap}-\mathrm{SQ}-\mathrm{BQ})(1 \%)$ & $1 / 2$ & $(\mathrm{CH} 2 \mathrm{Cl}) 2$ & 20 & $2 \mathrm{~h}$ & $99 \%$ & $1.44: 1$ \\
5 & S-Cu(BINap-SQ-BQ) (1\%) & $1 / 2$ & $\mathrm{CHCl} 3$ & 20 & $2 \mathrm{~h}$ & $80 \%$ & $1.36: 1$ \\
\hline
\end{tabular}

Table SI-14: The influence of different complexes

\begin{tabular}{cccccc}
\hline Entry & Complex & Solvent & Time & Temp. & Yield \\
\hline 1 & $\mathrm{Cu}\left(\mathrm{BINap}-\mathrm{SQ}_{2}\right)(1 \%)$ & $\mathrm{DCM}(1 \mathrm{ml})$ & $2 \mathrm{~h}^{\mathrm{a}} / 20 \mathrm{~min}^{\mathrm{b}}$ & r.t. & $33 \% / 0 \%$ \\
2 & $\mathrm{Cu}(\mathrm{BINap}-\mathrm{SQ}-\mathrm{BQ})(1 \%)$ & $\mathrm{DCM}(1 \mathrm{ml})$ & $2 \mathrm{~h}^{\mathrm{a}} / 20 \mathrm{~min}^{\mathrm{b}}$ & r.t. & $99 \% / 99 \%$ \\
3 & $\mathrm{Cu}\left(\mathrm{BINap}-\mathrm{BQ}_{2}\right)(1 \%)$ & $\mathrm{DCM}(1 \mathrm{ml})$ & $2 \mathrm{~h}^{\mathrm{a}} / 20 \mathrm{~min}^{\mathrm{b}}$ & r.t & $76 \% / 67 \%$ \\
4 & $\mathrm{Cu}(\mathrm{SQ})_{2}(1 \%)$ & $\mathrm{DCM}(1 \mathrm{ml})$ & $2 \mathrm{~h}^{\mathrm{a}} / 20 \mathrm{~min}^{\mathrm{b}}$ & r.t. & $41 \% / 12 \%$ \\
5 & $\mathrm{Cu}(\mathrm{SQ})(\mathrm{BQ})(1 \%)$ & $\mathrm{DCM}(1 \mathrm{ml})$ & $2 \mathrm{~h}^{\mathrm{a}} / 20 \mathrm{~min}^{\mathrm{b}}$ & r.t. & $93 \% / 75 \%$ \\
6 & $\mathrm{Cu}(\mathrm{BQ}) 2(1 \%)$ & $\mathrm{DCM}(1 \mathrm{ml})$ & $2 \mathrm{~h}^{\mathrm{a}} / 20 \min ^{\mathrm{b}}$ & r.t. & $90 \% / 70 \%$ \\
\hline
\end{tabular}

${ }^{\mathrm{a}}$ EDA was added in 2 hours, ${ }^{\mathrm{b}}$ EDA was added in 20 minutes. 


\section{Representative procedure for the cyclopropanation}

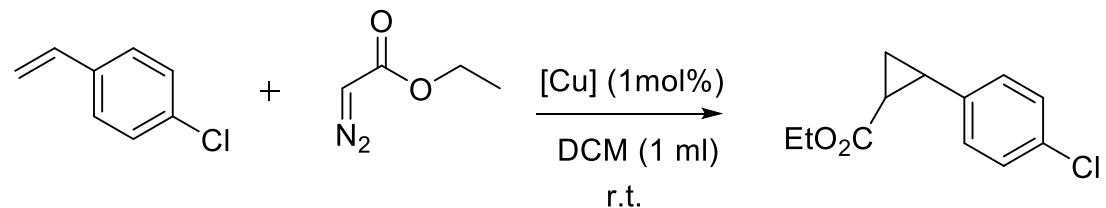

In a Schlenk flask (under argon or opened to air) were introduced copper complex (0.01 mmol, 1 mol\%), 4-chlorostyrene (126 $\mu \mathrm{L}, 1 \mathrm{mmol}, 1$ equiv.) and $\mathrm{DCM}(1 \mathrm{~mL})$. Ethyl diazoacetate(EDA) was then added $(210 \mu \mathrm{L}, 2 \mathrm{mmol}, 2$ equiv.) in 20 minutes. Then the solution was concentrated under vacuum. Purification by silica gel column chromatography (elution: Petroleum ether / Ethyl acetate) afforded the final product as a colorless oil.

${ }^{1} \mathrm{H}$ NMR yields were determined using trimethoxybenzene as internal standard and calculated considering styrene as limiting reactant. 
Mechanistic studies of cyclopropanation by mass spectrometry, UV-vis and ${ }^{1} \mathrm{H}$ NMR spectroscopies

\section{Mass spectrometry}

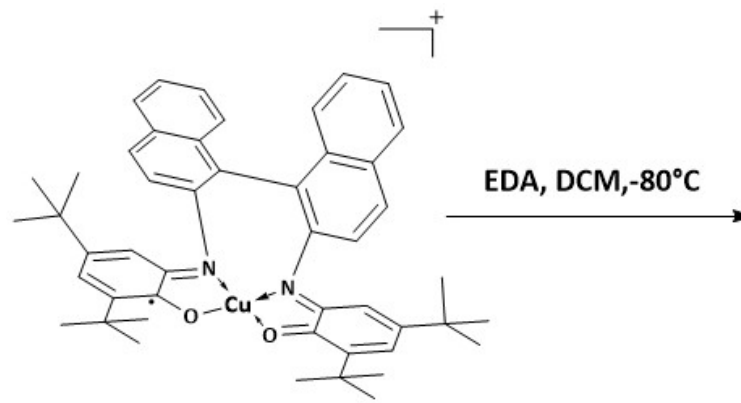

Exact Mass: 751.3325

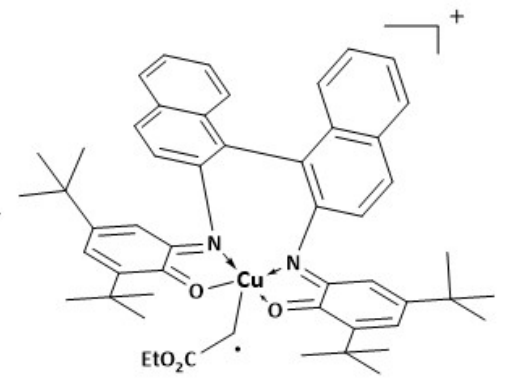

Exact Mass: 837.3693

Proposed structure for reactive intermediate

Protocol: To a solution of [Cu(BINap-SQ-BQ) $]^{+}$in DCM $(0.2 \mathrm{mg} / 2 \mathrm{ml})$ kept at $-80{ }^{\circ} \mathrm{C}$, EDA (10 $\mathrm{mg}$ ) was added. After $10 \mathrm{~min}$ and $45 \mathrm{~min}$, the solution was filtered quickly and diluted 10 times at $-80{ }^{\circ} \mathrm{C}$ and quickly injected in the mass spectrometer. The intermediate was formed after $10 \mathrm{~min}$ at $-80{ }^{\circ} \mathrm{C}$, however the signal was weak. As time going on $45 \mathrm{~min}$, the signal of the intermediate increase and the signal of [Cu(BINap-SQ-BQ $)]^{+}$decrease.

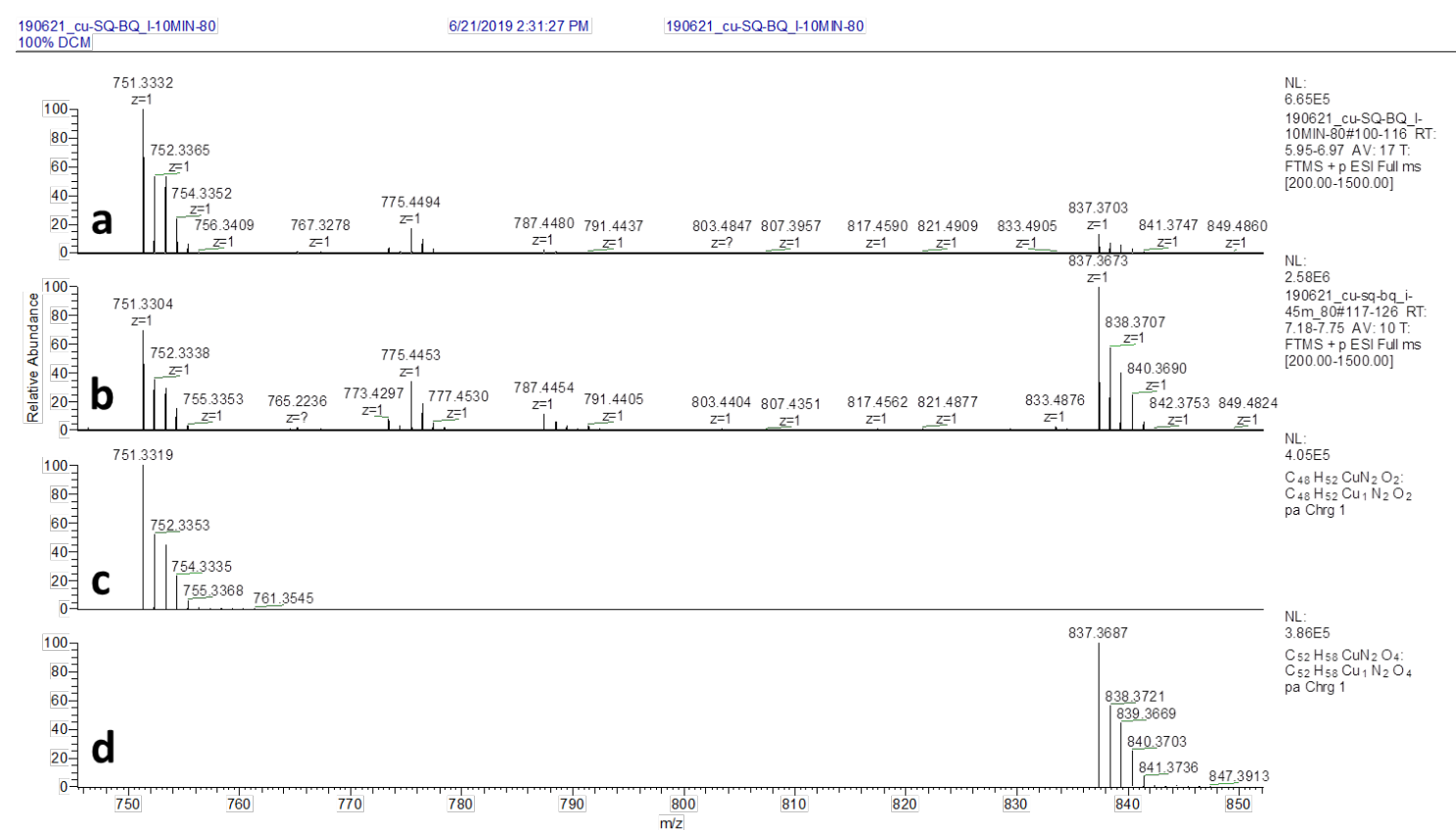

Figure SI-20: (a) 10 minutes after the EDA is added at $-80^{\circ} \mathrm{C}$, (b) 45 minutes after the EDA is added at $-80^{\circ} \mathrm{C}$, (c) simulated data of [Cu(BINap-SQ-BQ) $]^{+}$, (d) simulated data of intermediate. 


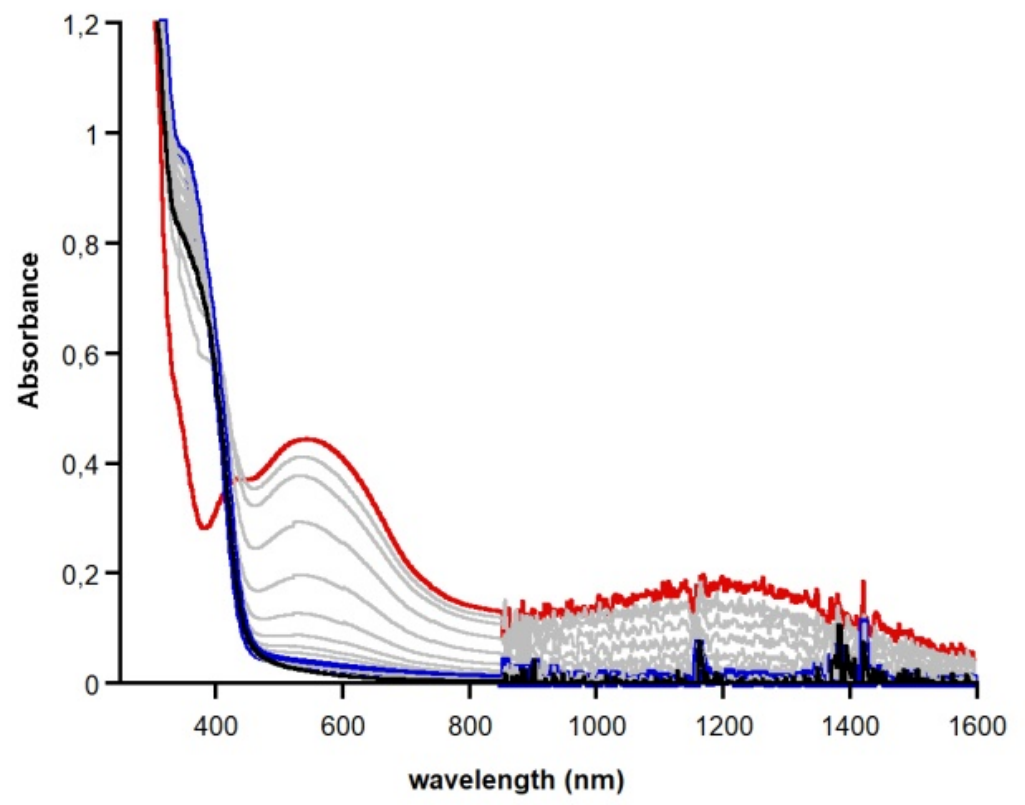

Figurg SI-21: Evolution of the reaction of $0.05 \mathrm{mM} \mathrm{Cu}(\mathrm{BINap}-\mathrm{SQ}-\mathrm{BQ})+10 \mathrm{mg}$ of EDA monitored by UV-Vis-NIR spectroscopy in distilled DCM at $0^{\circ} \mathrm{C}$ under argon atmosphere. Red trace: initial spectrum $\mathrm{CuL}(\mathrm{SQ})(\mathrm{BQ})$. Blue trace: $21 \mathrm{~min}$ after addition of EDA in a total volume of $2.5 \mathrm{ml}$ at $0{ }^{\circ} \mathrm{C}$. Black trace: the final decay product of the immediate.

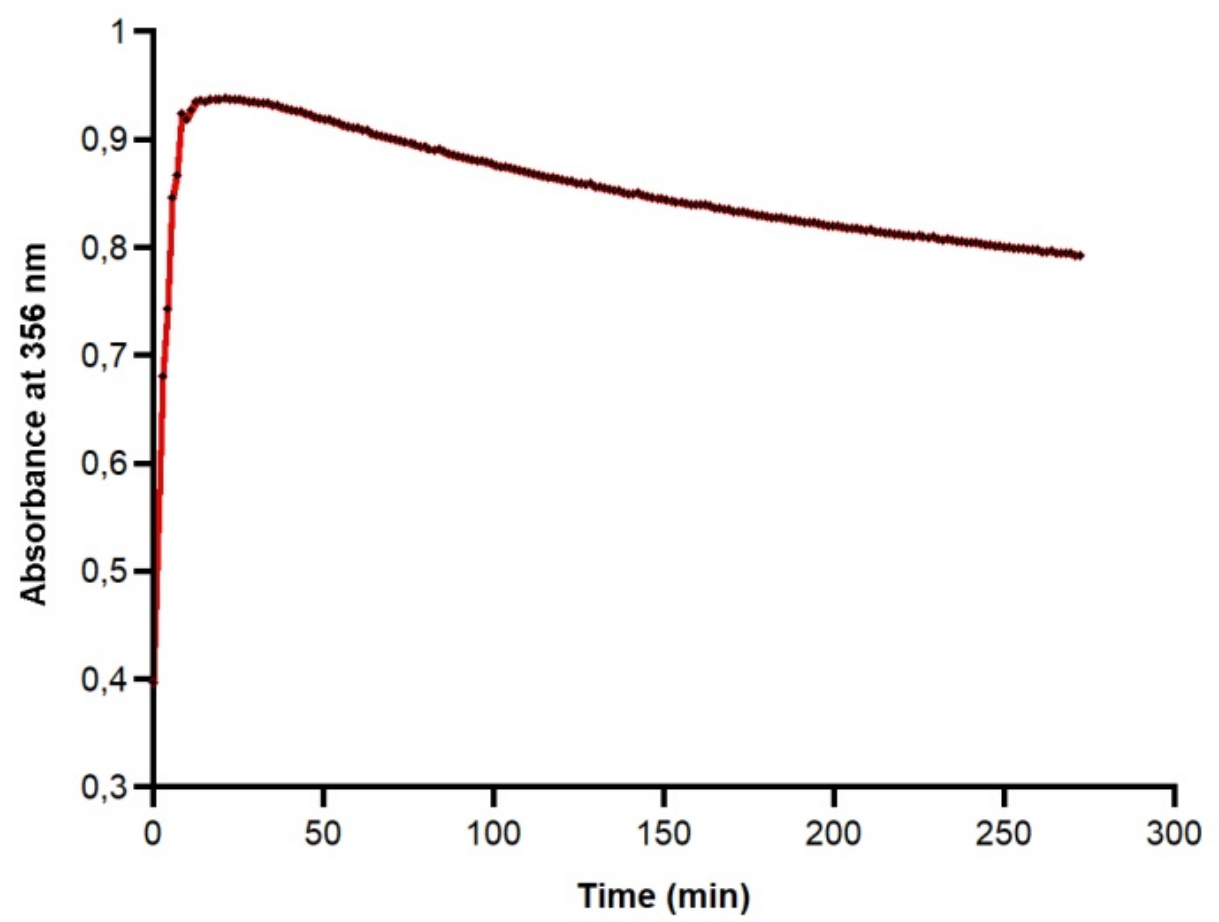

Figure SI-22: The degradation of the intermediate at $356 \mathrm{~nm}$ 


\section{${ }^{1} \mathrm{H}$ NMR kinetic studies}

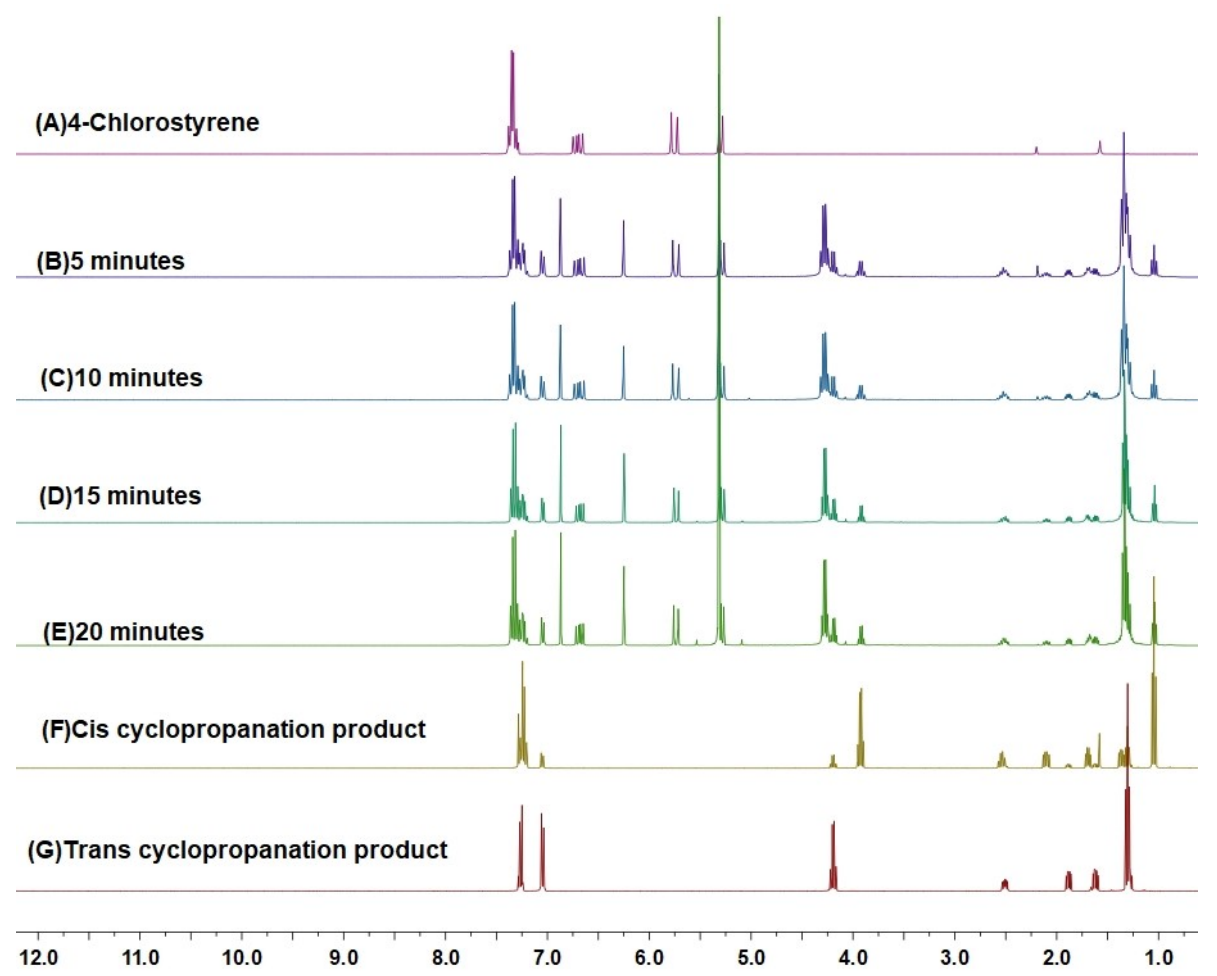

Figure SI-23: ${ }^{1} \mathrm{H}$ NMR kinetic study of the cyclopropanation reaction catalyzed by $\mathrm{Cu}(\mathrm{BINap}-\mathrm{SQ}-\mathrm{BQ})^{+}$. Reaction conditions: 4-chlorostyrene (1 equiv.), EDA (2 equiv.), copper complex (1 mol\%), DCM, rt. EDA was added totally at the beginning.

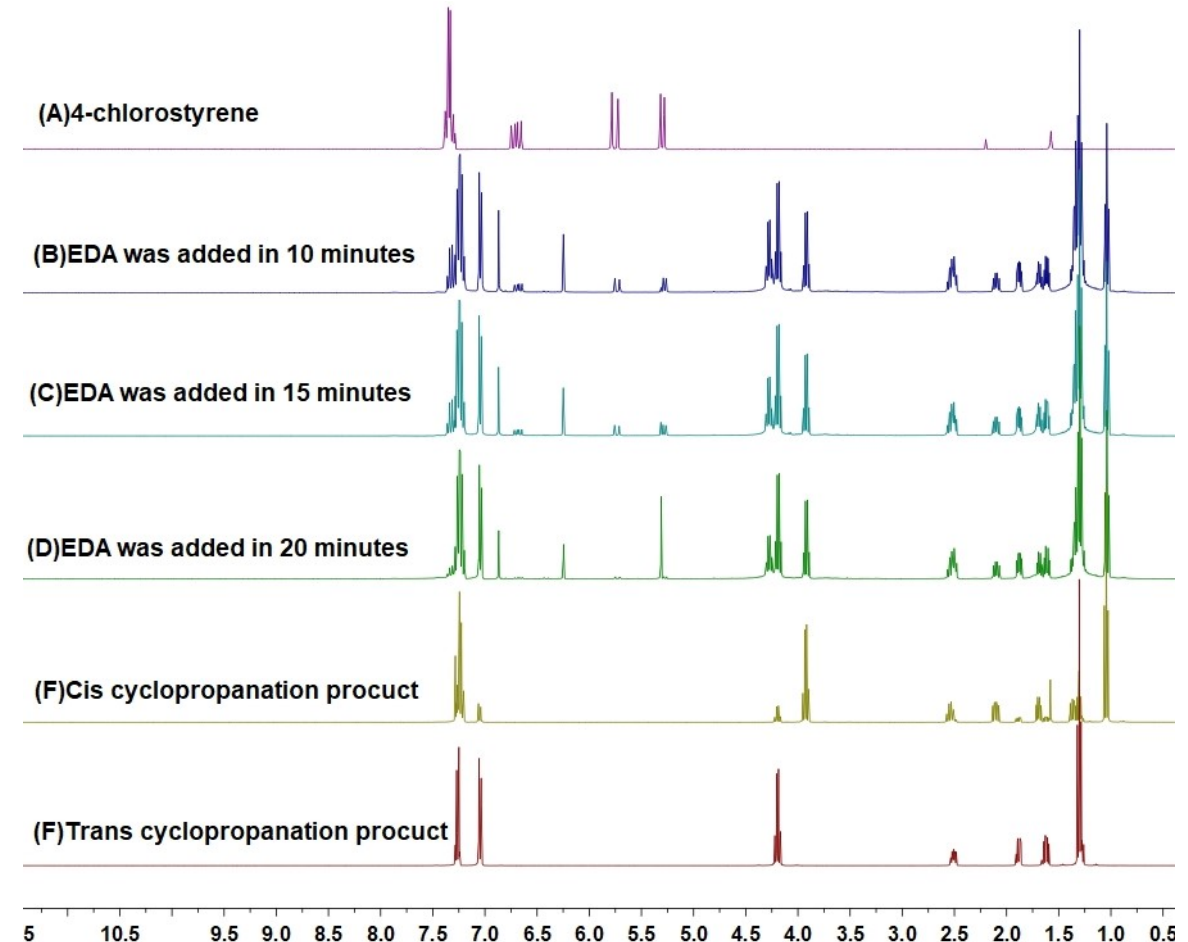

Figure SI-24: ${ }^{1} \mathrm{H}$ NMR kinetic study of the cyclopropanation reaction catalyzed by $\mathrm{Cu}(\mathrm{BINap}-\mathrm{SQ}-\mathrm{BQ})^{+}$. Reaction conditions: 4-chlorostyrene (1 equiv.),EDA (2 equiv.), copper complex (1 mol\%), DCM, rt. EDA was added slowly and finished in different times 


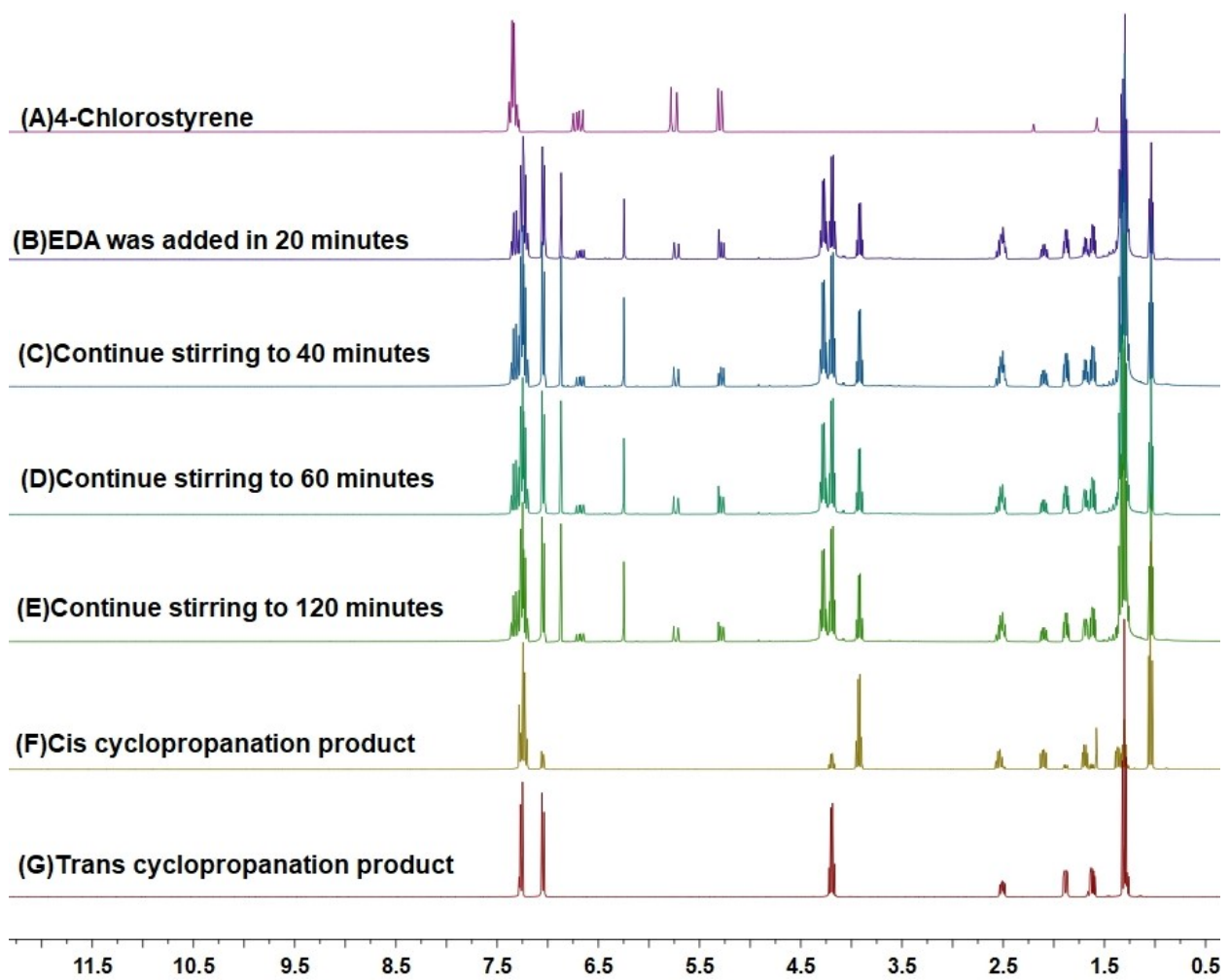

Figure SI-25. ${ }^{1} \mathrm{H}$ NMR kinetic study of the cyclopropanation reaction catalyzed by $\mathrm{Cu}(\mathrm{SQ})(\mathrm{BQ})^{+}$. Reaction conditions: 4-chlorostyrene (1 equiv.), EDA (2 equiv.), copper complex (1 mol\%), DCM, rt. EDA was added slowly in 20 minutes.

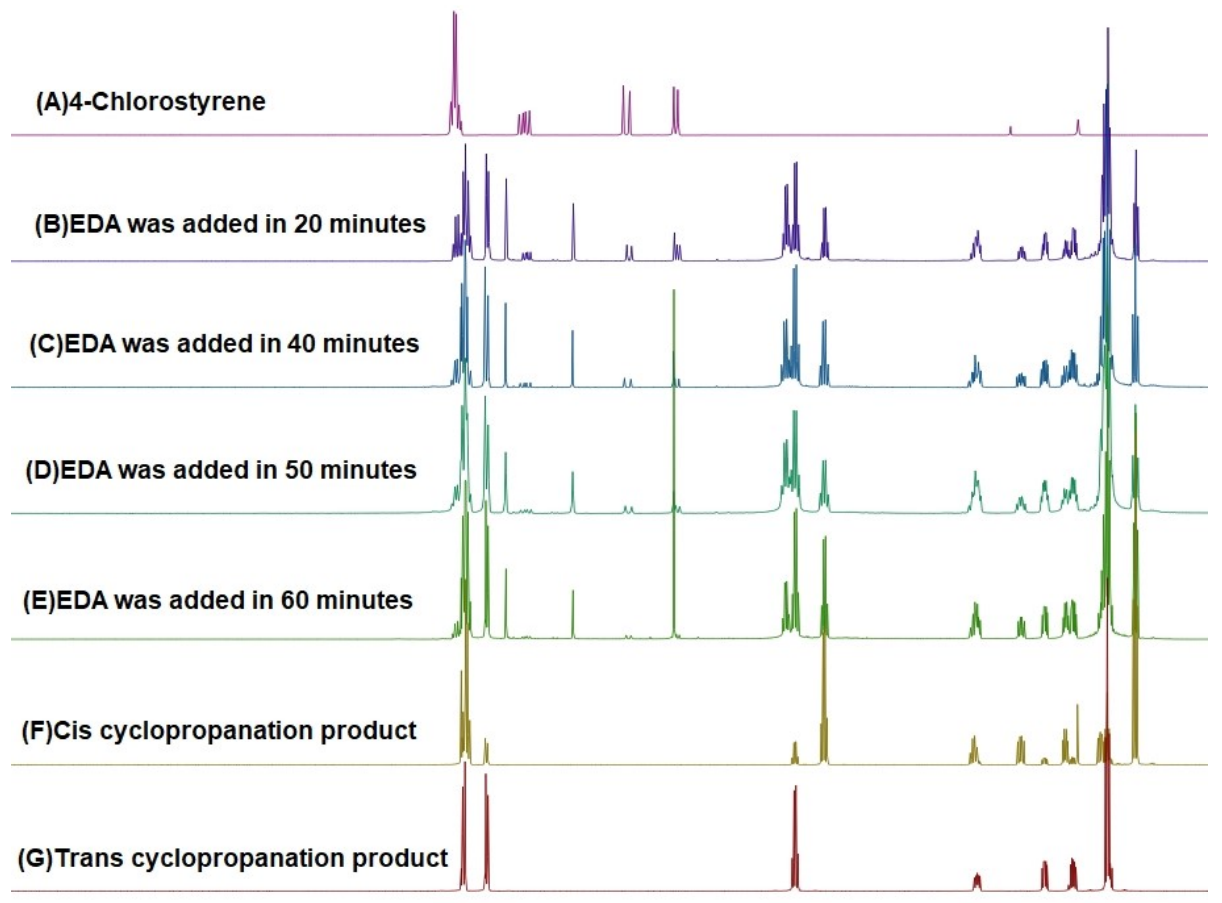

$\begin{array}{lllllllllllllllllllll}.5 & 10.5 & 9.5 & 9.0 & 8.5 & 8.0 & 7.5 & 7.0 & 6.5 & 6.0 & 5.5 & 5.0 & 4.5 & 4.0 & 3.5 & 3.0 & 2.5 & 2.0 & 1.5 & 1.0 & 0.5\end{array}$

Figure SI-26. ${ }^{1} \mathrm{H}$ NMR kinetic study of the cyclopropanation reaction catalyzed by $\mathrm{Cu}(\mathrm{SQ})(\mathrm{BQ})^{+}$. Reaction conditions: 4-chlorostyrene (1 equiv.), EDA (2 equiv.), copper complex (1 mol\%), DCM, rt. EDA was added slowly and finished in different times. 


\section{${ }^{1} \mathrm{H}$ and ${ }^{13} \mathrm{C}$ spectra of aziridination products}<smiles>[13CH3]N1CC1c1ccc(Cl)cc1</smiles>

8: ${ }^{1} \mathrm{H}$ NMR $\left(400 \mathrm{MHz}, \mathrm{CDCl}_{3}\right)$ $\delta$ 7.88-7.83 (m, $\left.2 \mathrm{H}\right), 7.34(\mathrm{~d}, J=8.0 \mathrm{~Hz}, 2 \mathrm{H}), 7.29-7.27(\mathrm{~m}, 1 \mathrm{H})$, $7.25(\mathrm{~d}, J=2.4 \mathrm{~Hz}, 1 \mathrm{H}), 7.17-7.13(\mathrm{~m}, 2 \mathrm{H}), 3.73(\mathrm{dd}, J=7.1,4.4 \mathrm{~Hz}, 1 \mathrm{H}), 2.98(\mathrm{~d}, J=7.2 \mathrm{~Hz}$, 1H), $2.44(\mathrm{~s}, 3 \mathrm{H}), 2.34(\mathrm{~d}, J=4.4 \mathrm{~Hz}, 1 \mathrm{H}) ;{ }^{13} \mathrm{C}$ NMR $\left(101 \mathrm{MHz}, \mathrm{CDCl}_{3}\right) \delta 144.8,134.88,134.2$, $133.7,129.8,128.8,127.9,40.2,36.0,21.7$.

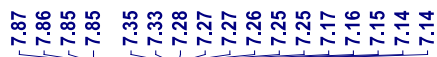

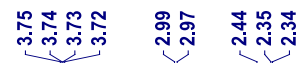
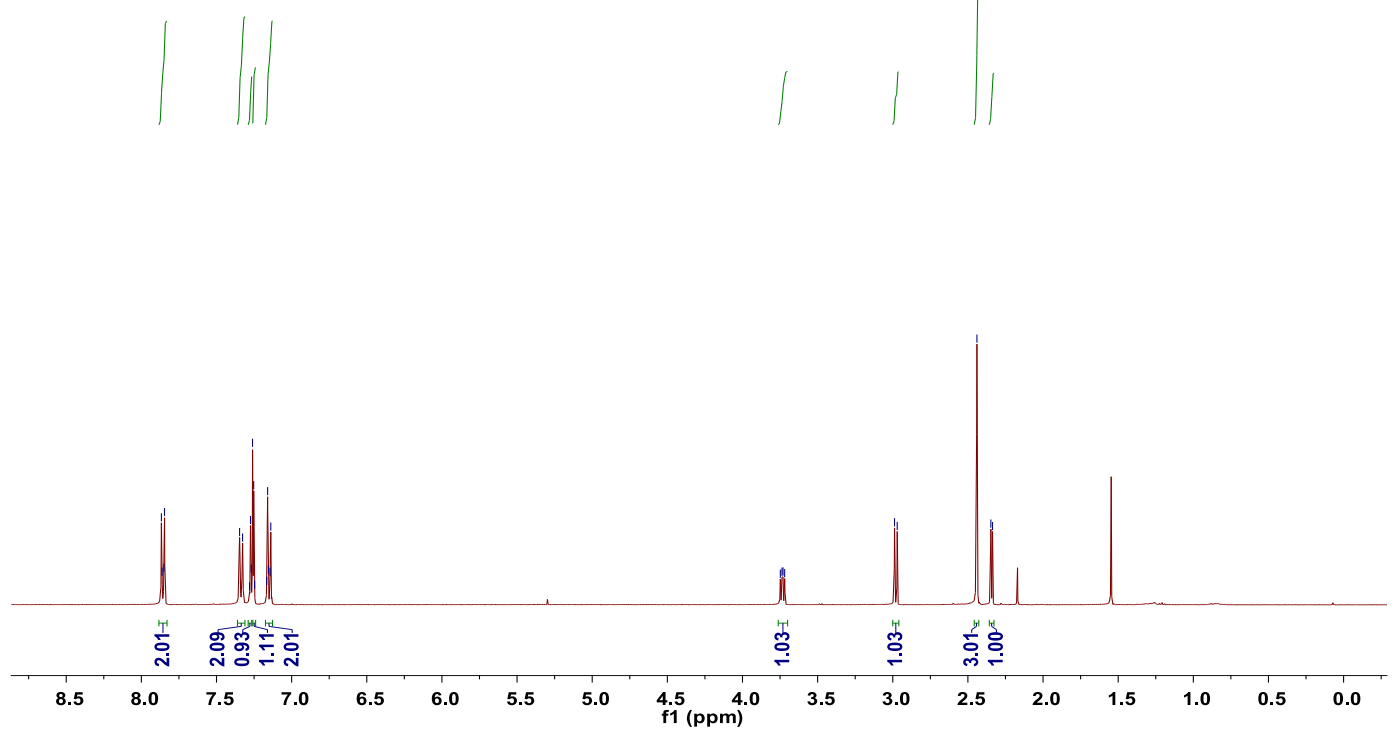

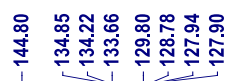

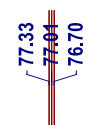

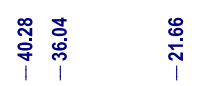

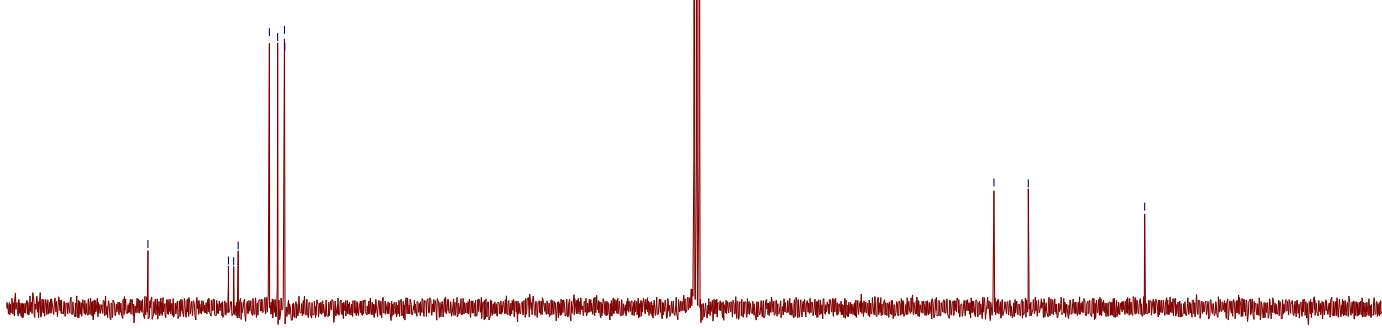

160

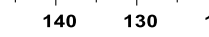

$120 \quad 110 \quad 100$

90

$\mathrm{f1}^{80}(\mathrm{ppm})$ 


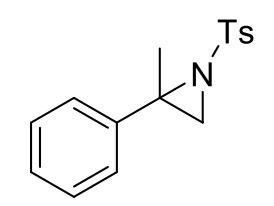

9: ${ }^{1} \mathrm{H}$ NMR $\left(400 \mathrm{MHz}, \mathrm{CDCl}_{3}\right) \delta 7.90-7.85(\mathrm{~m}, 2 \mathrm{H}), 7.38(\mathrm{dq}, J=2.9,2.0 \mathrm{~Hz}, 2 \mathrm{H}), 7.35-7.29$ (m, 4H), 7.27 (ddd, J = 8.6, 3.0, $1.5 \mathrm{~Hz}, 1 \mathrm{H}), 2.96(\mathrm{~s}, 1 \mathrm{H}), 2.52(\mathrm{~s}, 1 \mathrm{H}), 2.43(\mathrm{~s}, 3 \mathrm{H}), 2.05(\mathrm{~s}, 3 \mathrm{H})$; ${ }^{13} \mathrm{C}$ NMR $\left(101 \mathrm{MHz} \mathrm{CDCl}_{3}\right) \delta 143.9,141.0,137.8,129.5,128.4,127.7,127.5,126.5,51.8,41.8$, 21.6, 20.9.

9

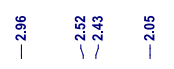
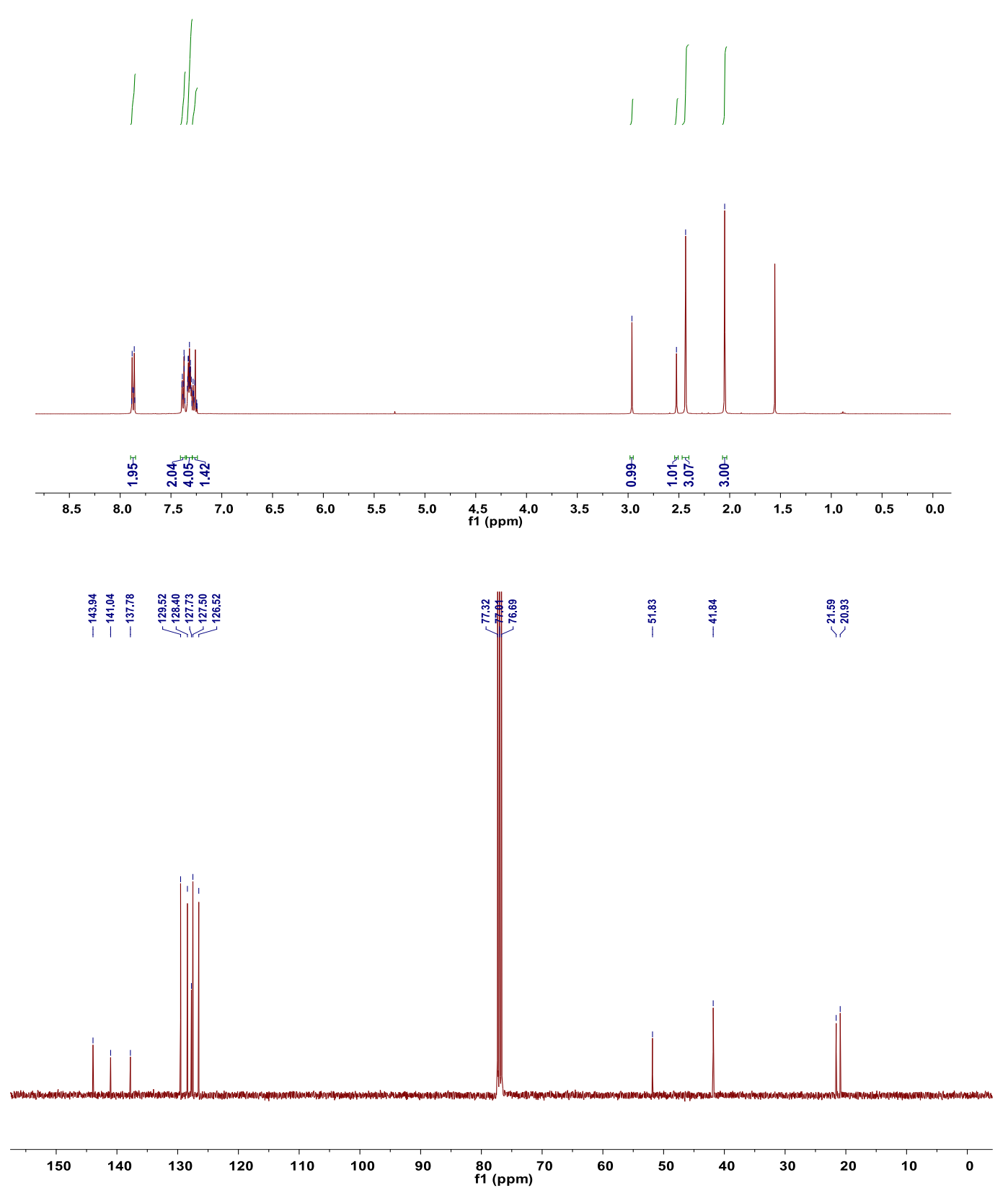


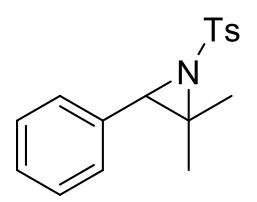

10: ${ }^{1} \mathrm{H}$ NMR $\left(400 \mathrm{MHz}, \mathrm{CDCl}_{3}\right) \delta 7.89-7.84(\mathrm{~m}, 2 \mathrm{H}), 7.30(\mathrm{dd}, J=8.6,0.6 \mathrm{~Hz}, 2 \mathrm{H}), 7.24-7.20$ (m, 2H), $7.06-7.00(\mathrm{~m}, 2 \mathrm{H}), 4.04(\mathrm{~s}, 1 \mathrm{H}), 2.43(\mathrm{~s}, 3 \mathrm{H}), 1.90(\mathrm{~s}, 3 \mathrm{H}), 1.06(\mathrm{~s}, 3 \mathrm{H}) ;{ }^{13} \mathrm{C}$ NMR $(101$ $\left.\mathrm{MHz}, \mathrm{CDCl}_{3}\right) \delta 143.8,138.3,134.2,129.5,128.2,127.6,127.3,127.0,53.8,53.6,21.6,21.2$ 21.1.
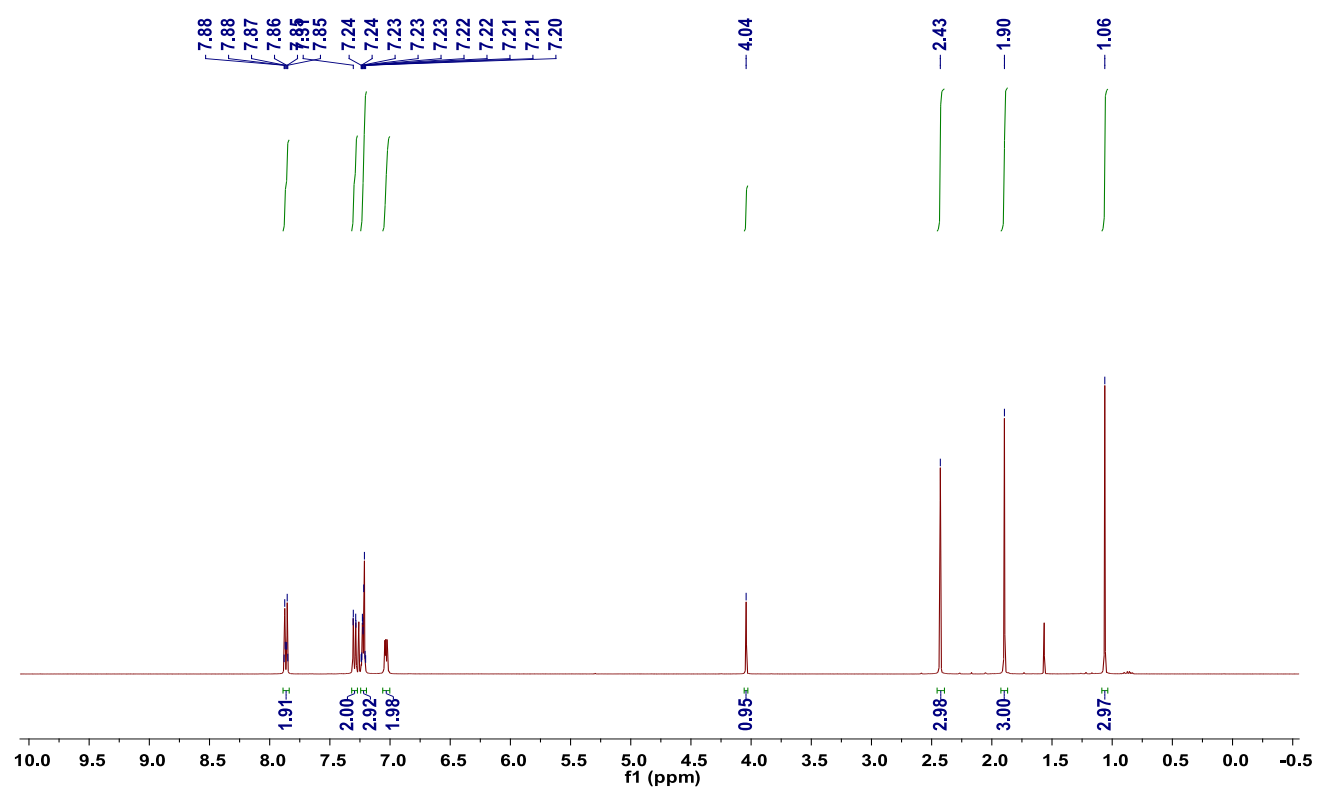

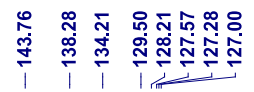
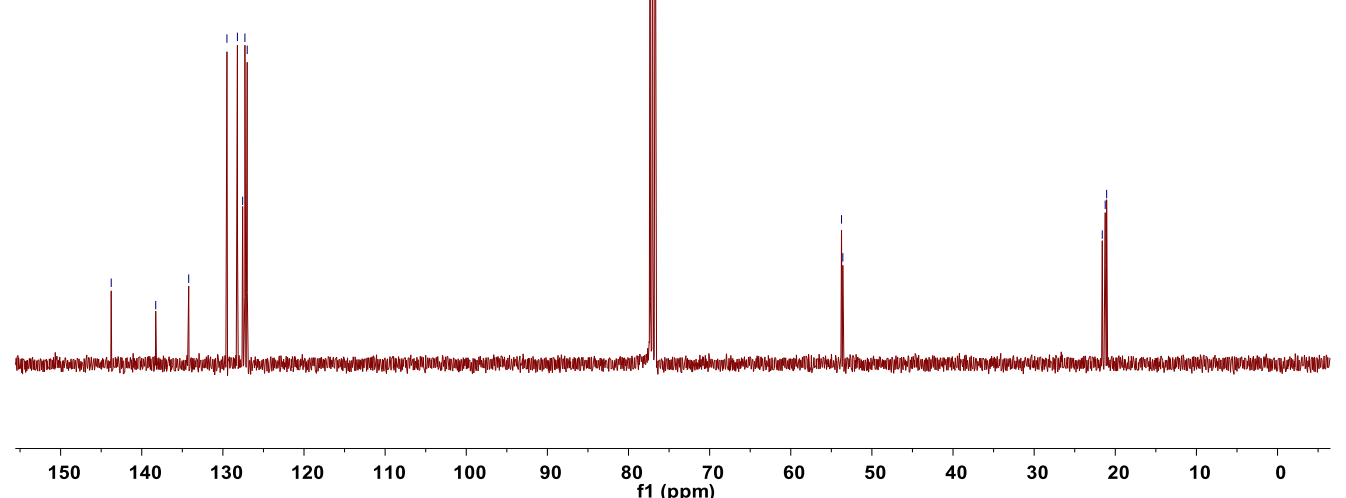


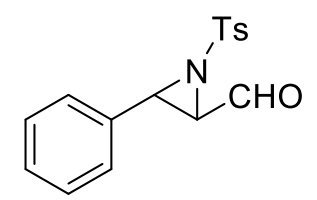

11: ${ }^{1} \mathrm{H}$ NMR $\left(400 \mathrm{MHz}, \mathrm{CDCl}_{3}\right) \delta 8.78(\mathrm{~d}, J=9.4 \mathrm{~Hz}, 1 \mathrm{H}), 7.88-7.83(\mathrm{~m}, 2 \mathrm{H}), 7.57-7.53(\mathrm{~m}$, 2H), $7.49(\mathrm{~d}, J=15.8 \mathrm{~Hz}, 1 \mathrm{H}), 7.46-7.39(\mathrm{~m}, 3 \mathrm{H}), 7.34(\mathrm{~d}, J=8.0 \mathrm{~Hz}, 2 \mathrm{H}), 6.99$ (dd, $J=15.8$, $9.4 \mathrm{~Hz}, 1 \mathrm{H}), 2.44(\mathrm{~s}, 3 \mathrm{H}) ;{ }^{13} \mathrm{C}$ NMR $\left(101 \mathrm{MHz}, \mathrm{CDCl}_{3}\right) \delta 170.8,153.8,144.5,135.4,134.2,131.6$, $129.8,129.2,128.6,128.0,124.8,21.7$.

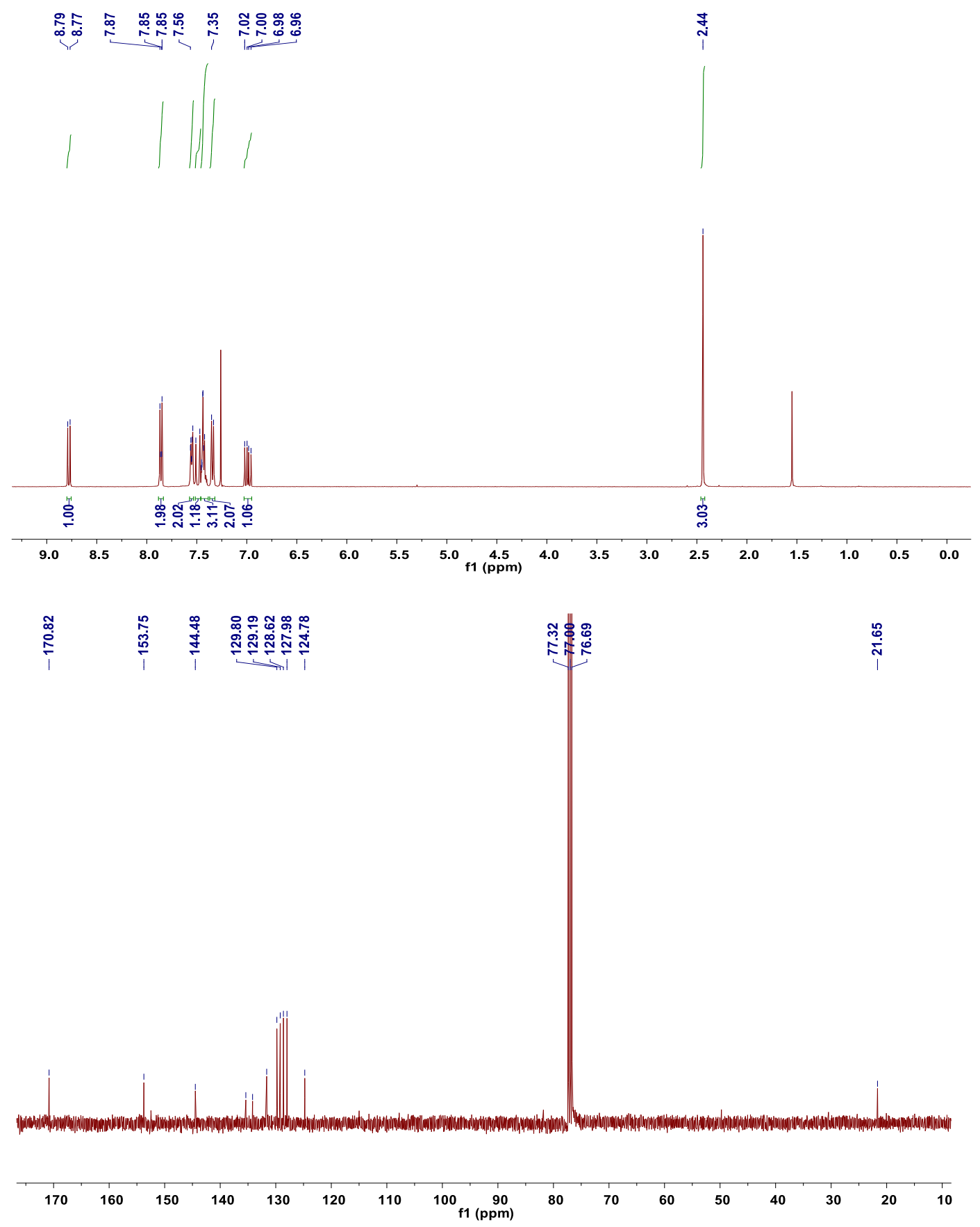




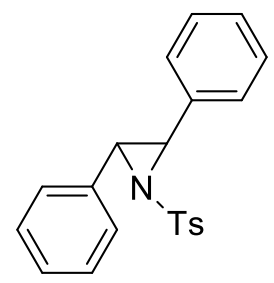

$12:{ }^{1} \mathrm{H}$ NMR $(400 \mathrm{MHz}, \mathrm{CDCl} 3) \delta 7.63(\mathrm{~d}, J=8.3 \mathrm{~Hz}, 2 \mathrm{H}), 7.42(\mathrm{dd}, J=6.6,3.2 \mathrm{~Hz}, 4 \mathrm{H}), 7.39-$ $7.32(\mathrm{~m}, 6 \mathrm{H}), 7.20(\mathrm{~d}, J=8.1 \mathrm{~Hz}, 2 \mathrm{H}), 4.27(\mathrm{~s}, 2 \mathrm{H}), 2.39(\mathrm{~s}, 3 \mathrm{H}) ;{ }^{13} \mathrm{C} \mathrm{NMR}\left(101 \mathrm{MHz}, \mathrm{CDCl}_{3}\right) \delta$ $143.9,137.1,133.1,129.4,128.7,128.4,127.5,77.3,50.4,21.6$.

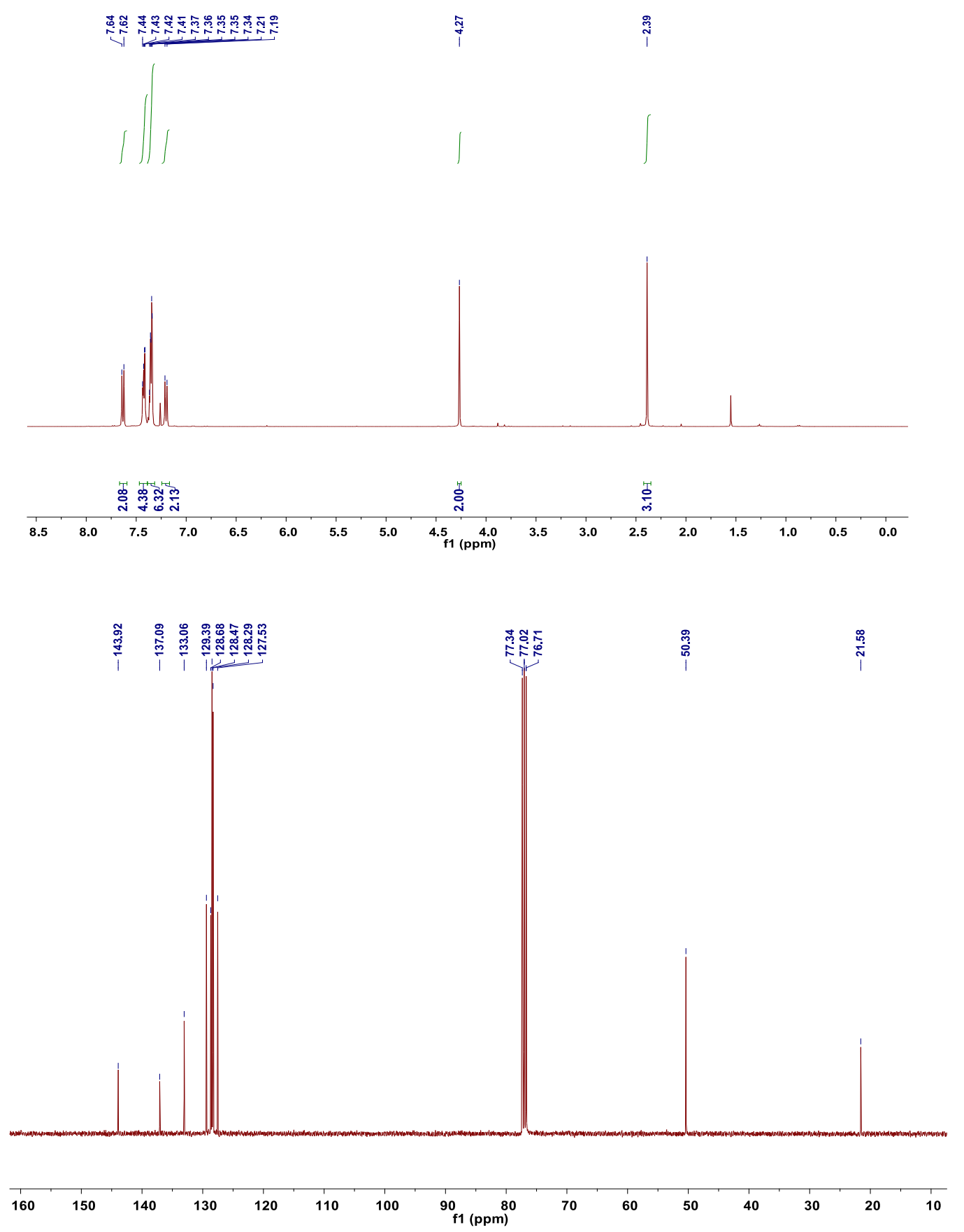



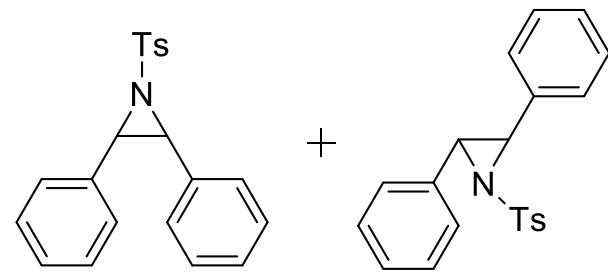

12 and 13: ${ }^{1} \mathrm{H}$ NMR (400 MHz, CDCl3) $\delta 7.96$ (d, $J=8.3 \mathrm{~Hz}, 2 \mathrm{H}$-cis), 7.63 (d, $J=8.3 \mathrm{~Hz}$, 2H-trans), $7.46-7.39$ (m, 4H-trans), $7.39-7.31$ (m, 6H-trans+2H-cis), 7.20 (d, J = $8.2 \mathrm{~Hz}$, 2H-trans), $7.15-7.08$ (m, 6H-cis), $7.07-7.00$ (m, 4H-cis), 4.26 (s, 2H-trans), 4.22 (s, 2H-cis), 2.45 (s, 3H-cis), 2.39 (s, 3H-trans).
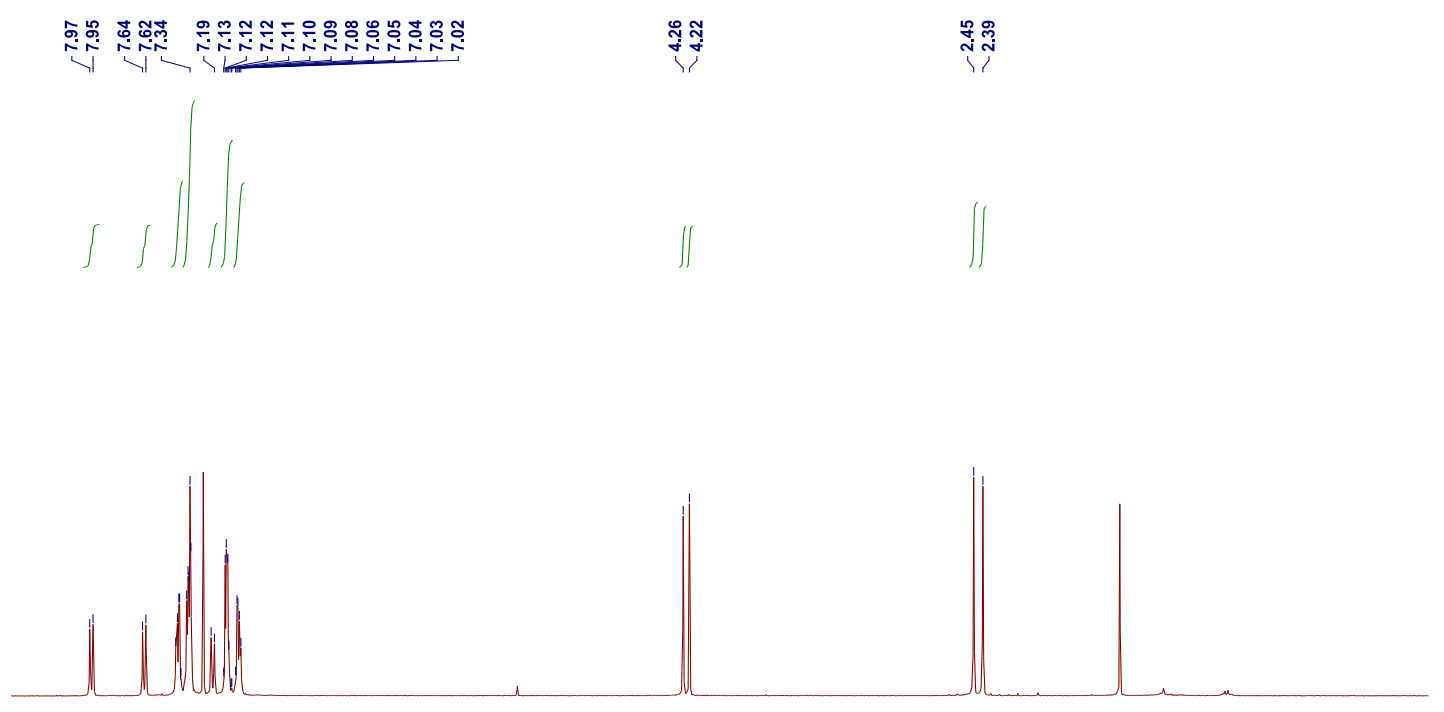

\begin{tabular}{|c|c|c|c|c|c|c|c|c|c|c|c|c|c|c|c|c|}
\hline ') & 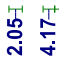 & 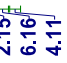 & & & & & & 'i & & & 点 & & & & & \\
\hline 8.0 & 7.5 & 7.0 & 6.5 & 6.0 & 5.5 & 5.0 & 4.5 & $\begin{array}{c}4.0 \\
\text { f1 (ppm) }\end{array}$ & 3.5 & 3.0 & 2.5 & 2.0 & 1.5 & 1.0 & 0.5 & 0.0 \\
\hline
\end{tabular}


<smiles>O=C(c1ccccc1)C1C2CN1C21c2ccccc21</smiles>

14: ${ }^{1} \mathrm{H}$ NMR $\left(400 \mathrm{MHz}, \mathrm{CDCl}_{3}\right) \delta 8.10-8.00(\mathrm{~m}, 2 \mathrm{H}), 7.76-7.69(\mathrm{~m}, 2 \mathrm{H}), 7.66-7.59(\mathrm{~m}, 1 \mathrm{H})$, 7.49 (dd, $J=10.9,4.5 \mathrm{~Hz}, 2 \mathrm{H}), 7.40-7.30(\mathrm{~m}, 5 \mathrm{H}), 7.23(\mathrm{~d}, J=8.0 \mathrm{~Hz}, 2 \mathrm{H}), 4.52(\mathrm{~d}, J=4.2 \mathrm{~Hz}$, $1 \mathrm{H}), 4.29(\mathrm{~d}, J=4.2 \mathrm{~Hz}, 1 \mathrm{H}), 2.40(\mathrm{~s}, 3 \mathrm{H}) ;{ }^{13} \mathrm{C} \mathrm{NMR}\left(101 \mathrm{MHz}, \mathrm{CDCl}_{3}\right) \delta 190.3,144.4,136.7$, 136.0, 134.1, 132.9, 129.5, 128.9, 128.9, 128.8, 128.6, 127.7, 127.5, 50.2, 47.5, 21.6.
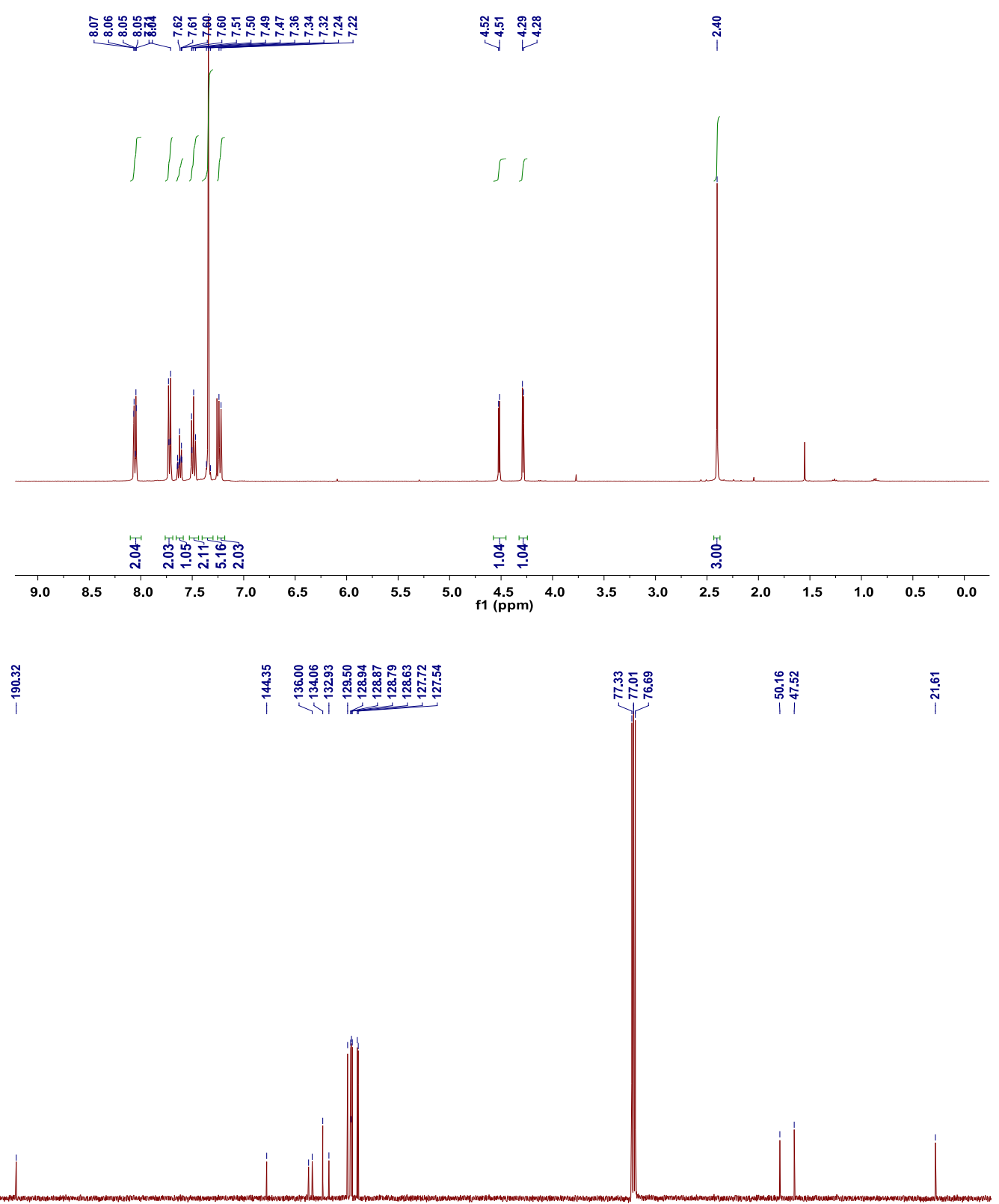

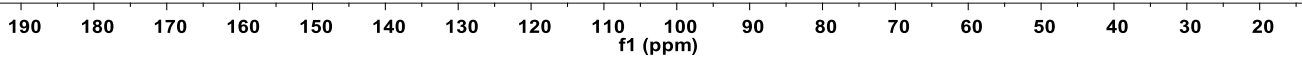




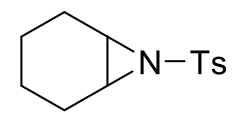

15: ${ }^{1} \mathrm{H}$ NMR $\left(300 \mathrm{MHz}, \mathrm{CDCl}_{3}\right) \delta 7.82(\mathrm{~d}, J=8.3 \mathrm{~Hz}, 2 \mathrm{H}), 7.32(\mathrm{~d}, J=8.0 \mathrm{~Hz}, 2 \mathrm{H}), 3.01-2.93(\mathrm{~m}$, 2H), $2.44(\mathrm{~s}, 3 \mathrm{H}), 1.78(\mathrm{dd}, J=8.4,3.3 \mathrm{~Hz}, 4 \mathrm{H}), 1.39$ (ddd, $J=10.2,6.8,2.6 \mathrm{~Hz}, 2 \mathrm{H}$ ), 1.19 (ddd, $J=8.8,6.7,3.0 \mathrm{~Hz}, 2 \mathrm{H}) ;{ }^{13} \mathrm{C}$ NMR $\left(101 \mathrm{MHz}, \mathrm{CDCl}_{3}\right) \delta 143.9,135.9,129.6,127.6,39.8,22.8$, 21.6, 19.4 .

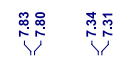

每
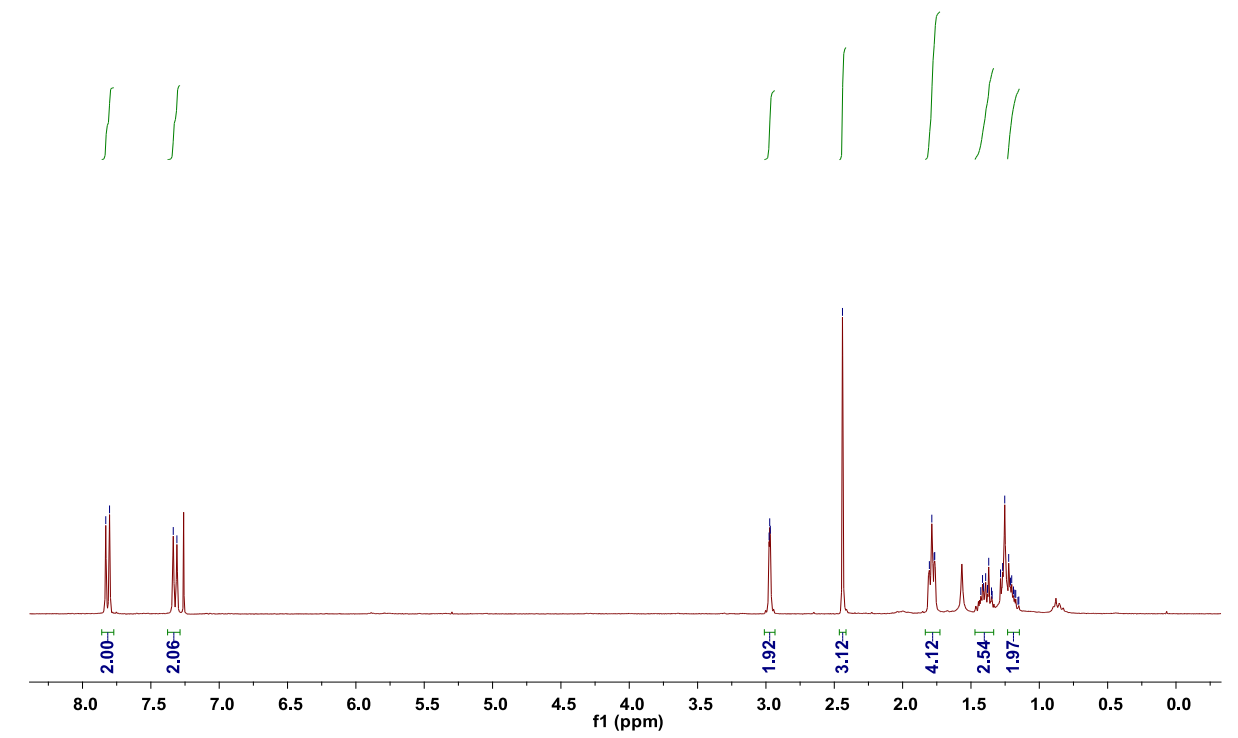

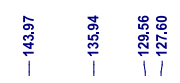

赵

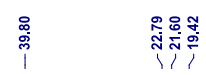

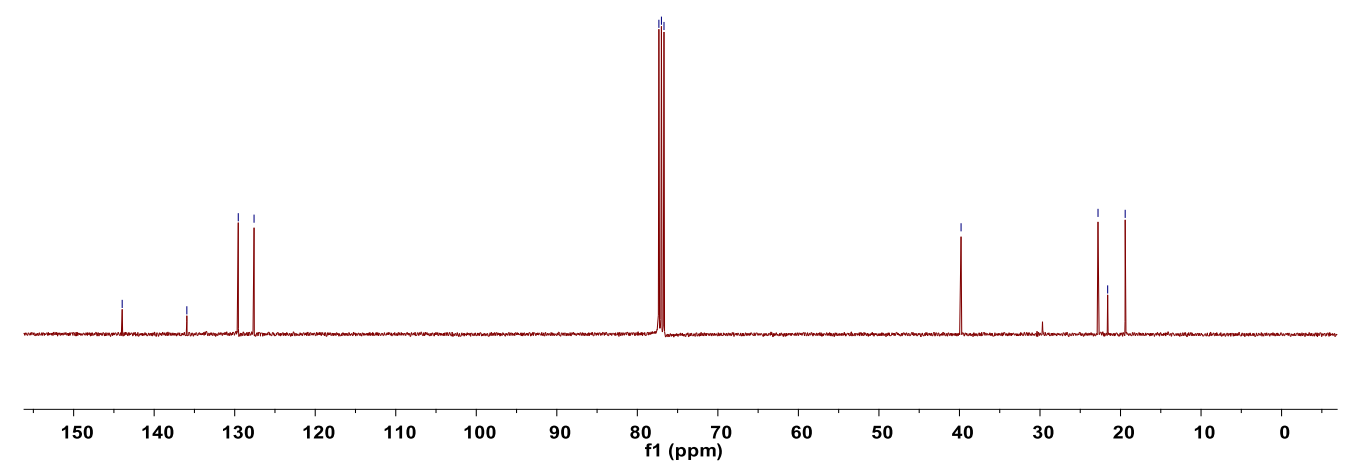




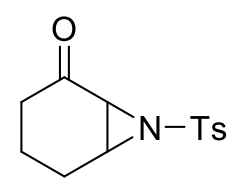

16: ${ }^{1} \mathrm{H}$ NMR $\left(400 \mathrm{MHz}, \mathrm{CDCl}_{3}\right) \delta 7.83-7.79(\mathrm{~m}, 2 \mathrm{H}), 7.35(\mathrm{dd}, J=8.5,0.6 \mathrm{~Hz}, 2 \mathrm{H}), 3.48-3.43$ (m, 1H), $3.15(\mathrm{~d}, J=6.6 \mathrm{~Hz}, 1 \mathrm{H}), 2.45(\mathrm{~s}, 3 \mathrm{H}), 2.44-2.37(\mathrm{~m}, 1 \mathrm{H}), 2.23-2.14(\mathrm{~m}, 1 \mathrm{H}), 2.03$ (ddd, $J=17.4,8.7,3.6 \mathrm{~Hz}, 1 \mathrm{H}), 1.96-1.80(\mathrm{~m}, 2 \mathrm{H}), 1.67(\mathrm{ddd}, J=14.5,7.4,3.7 \mathrm{~Hz}, 1 \mathrm{H}) ;{ }^{13} \mathrm{C}$ NMR (101 MHz, $\left.\mathrm{CDCl}_{3}\right) \delta$ 201.3, 145.1, 134.4, 129.9, 127.9, 43.9, 40.9, 37.1, 21.8, 21.7, 17.1.
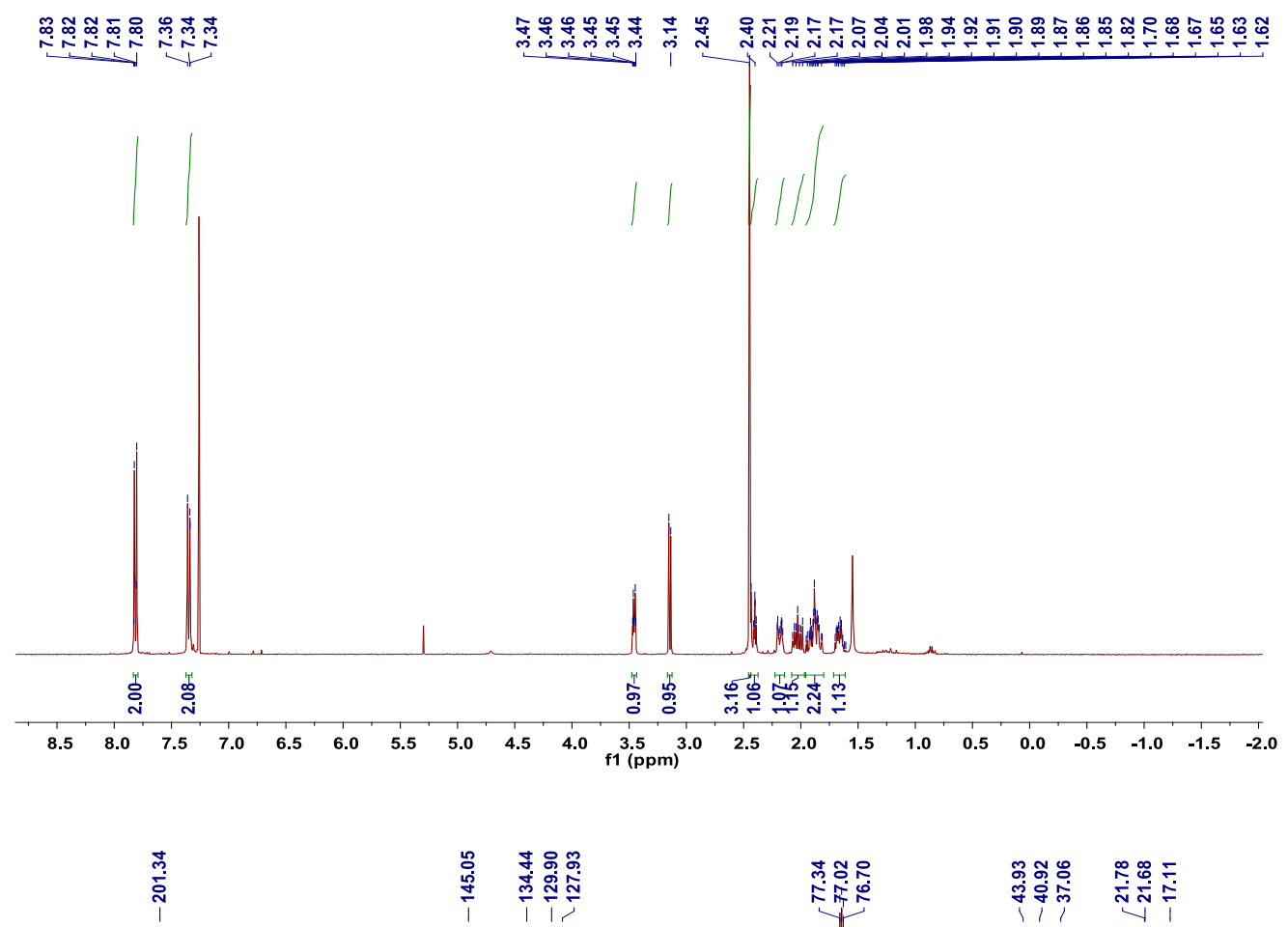

$\begin{array}{lllllllllllllllllllllll}220 & 210 & 200 & 190 & 180 & 170 & 160 & 150 & 140 & 130 & 120 & 110 & 100 & 90 & 80 & 70 & 60 & 50 & 40 & 30 & 20 & 10 & 0\end{array}$ 


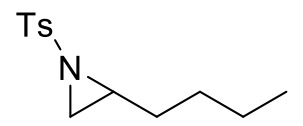

17: ${ }^{1} \mathrm{H}$ NMR $\left(400 \mathrm{MHz}, \mathrm{CDCl}_{3}\right) \delta 7.86-7.78(\mathrm{~m}, 2 \mathrm{H}), 7.32(\mathrm{~d}, J=0.6 \mathrm{~Hz}, 2 \mathrm{H}), 2.72(\mathrm{tt}, J=7.3$, $4.8 \mathrm{~Hz}, 1 \mathrm{H}), 2.62(\mathrm{~d}, J=7.0 \mathrm{~Hz}, 1 \mathrm{H}), 2.44(\mathrm{~s}, 3 \mathrm{H}), 2.05(\mathrm{~d}, J=4.6 \mathrm{~Hz}, 1 \mathrm{H}), 1.59-1.47(\mathrm{~m}, 1 \mathrm{H})$, $1.34(\mathrm{td}, J=14.1,7.3 \mathrm{~Hz}, 1 \mathrm{H}), 1.28-1.15(\mathrm{~m}, 4 \mathrm{H}), 0.81(\mathrm{dd}, J=8.4,5.7 \mathrm{~Hz}, 3 \mathrm{H}) ;{ }^{13} \mathrm{C}$ NMR $(101$ $\left.\mathrm{MHz}, \mathrm{CDCl}_{3}\right) \delta 144.4,135.2,129.6,127.9,40.4,33.8,31.0,28.9,22.1,21.6,13.8$.
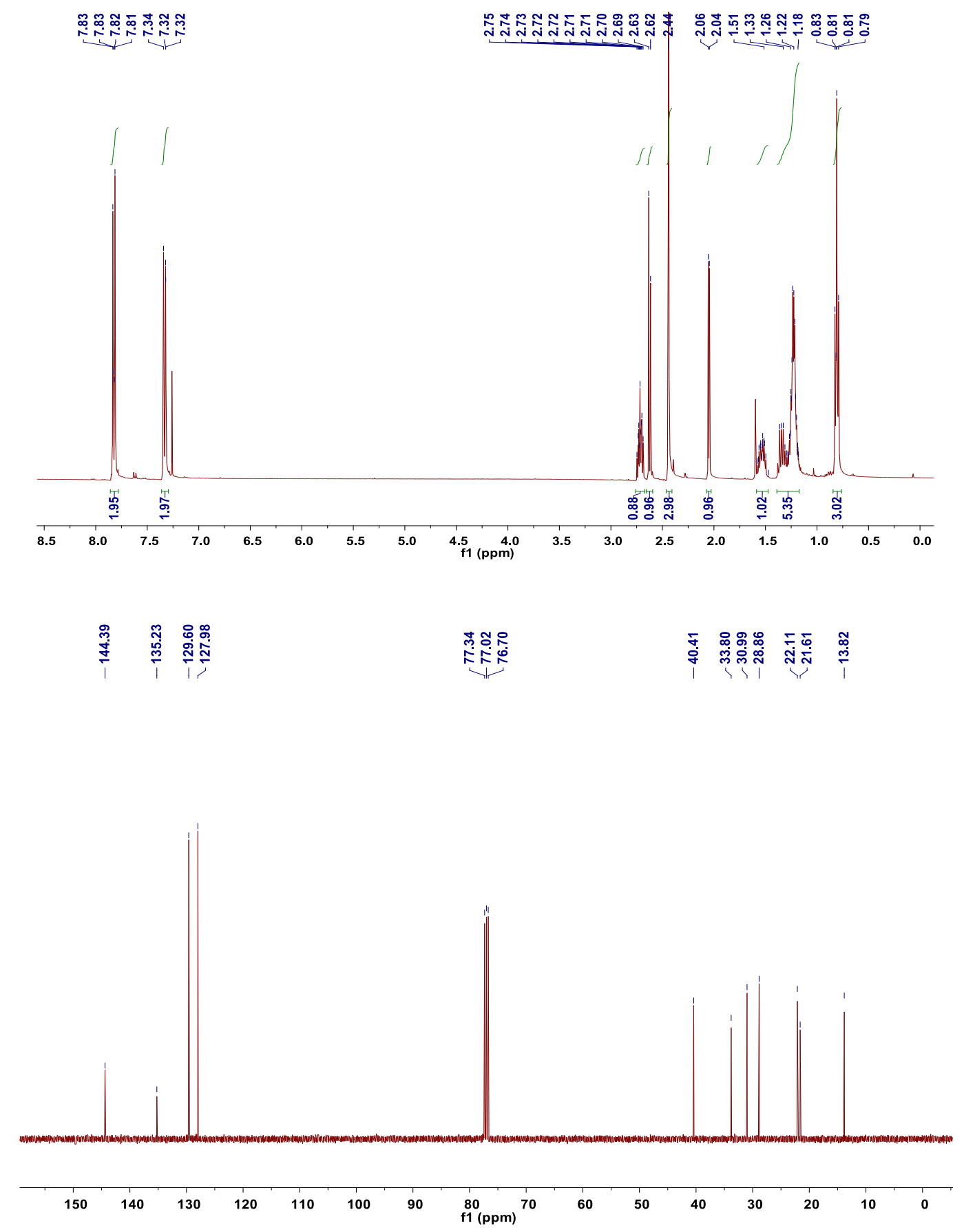


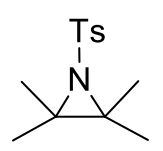

18: ${ }^{1} \mathrm{H}$ NMR $\left(400 \mathrm{MHz}, \mathrm{CDCl}_{3}\right) \delta 7.79(\mathrm{~d}, J=8.2 \mathrm{~Hz}, 2 \mathrm{H}), 7.28(\mathrm{~d}, J=8.0 \mathrm{~Hz}, 2 \mathrm{H}), 2.42(\mathrm{~s}, 3 \mathrm{H})$, $1.47(\mathrm{~s}, 12 \mathrm{H}) ;{ }^{13} \mathrm{C}$ NMR $\left(101 \mathrm{MHz}, \mathrm{CDCl}_{3}\right) \delta 143.1,139.9,129.3,126.8,53.0,21.5,20.2$.

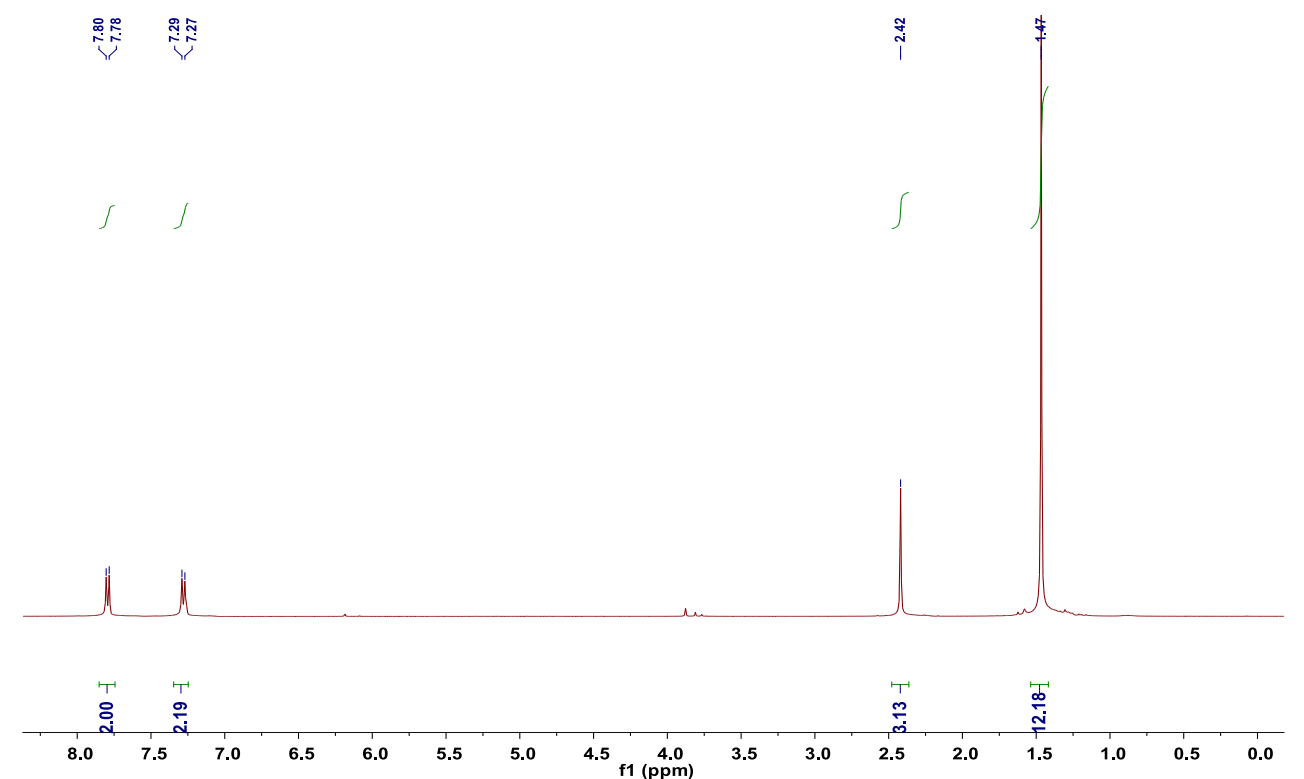

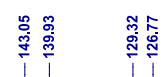

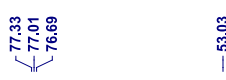

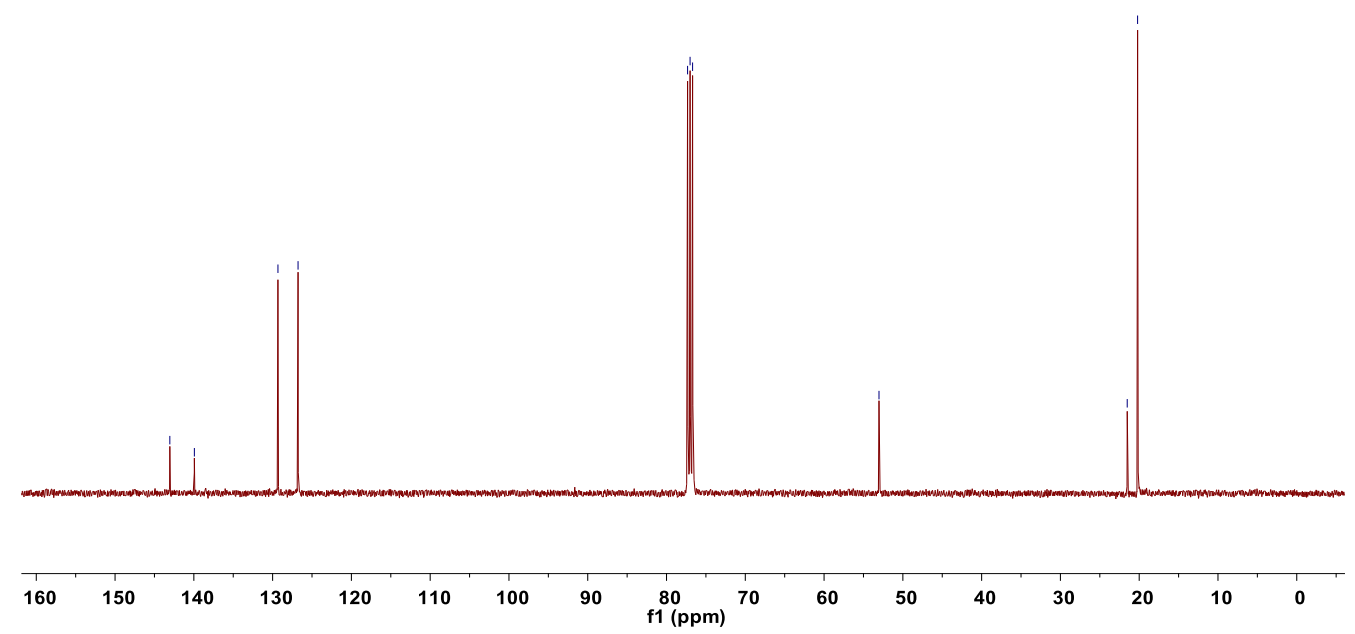




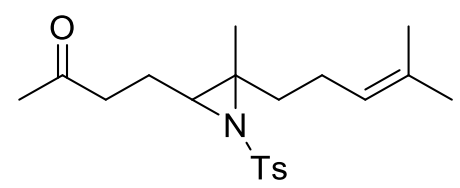

19: ${ }^{1} \mathrm{H}$ NMR $\left(400 \mathrm{MHz}, \mathrm{CDCl}_{3}\right) \delta 7.84-7.79(\mathrm{~m}, 2 \mathrm{H}), 7.30(\mathrm{dd}, J=8.5,0.6 \mathrm{~Hz}, 2 \mathrm{H}), 5.17-5.09$ (m, 1H), 4.07 (dd, $J=11.9,5.2 \mathrm{~Hz}, 1 \mathrm{H}), 3.88(\mathrm{dd}, J=11.9,7.6 \mathrm{~Hz}, 1 \mathrm{H}), 3.12(\mathrm{dd}, J=7.6,5.2 \mathrm{~Hz}$, 1H), $2.43(\mathrm{~s}, 3 \mathrm{H}), 2.34-2.02(\mathrm{~m}, 4 \mathrm{H}), 1.90(\mathrm{~s}, 3 \mathrm{H}), 1.70(\mathrm{~s}, 3 \mathrm{H}), 1.63(\mathrm{~s}, 3 \mathrm{H}), 1.34(\mathrm{~s}, 3 \mathrm{H}) ;{ }^{13} \mathrm{C}$ NMR $\left(101 \mathrm{MHz}, \mathrm{CDCl}_{3}\right) \delta 170.4,143.7,138.2,132.7,129.4,127.4,122.7,61.9,54.8,48.9$, $34.7,25.7,25.5,21.6,20.5,18.6,17.7$.

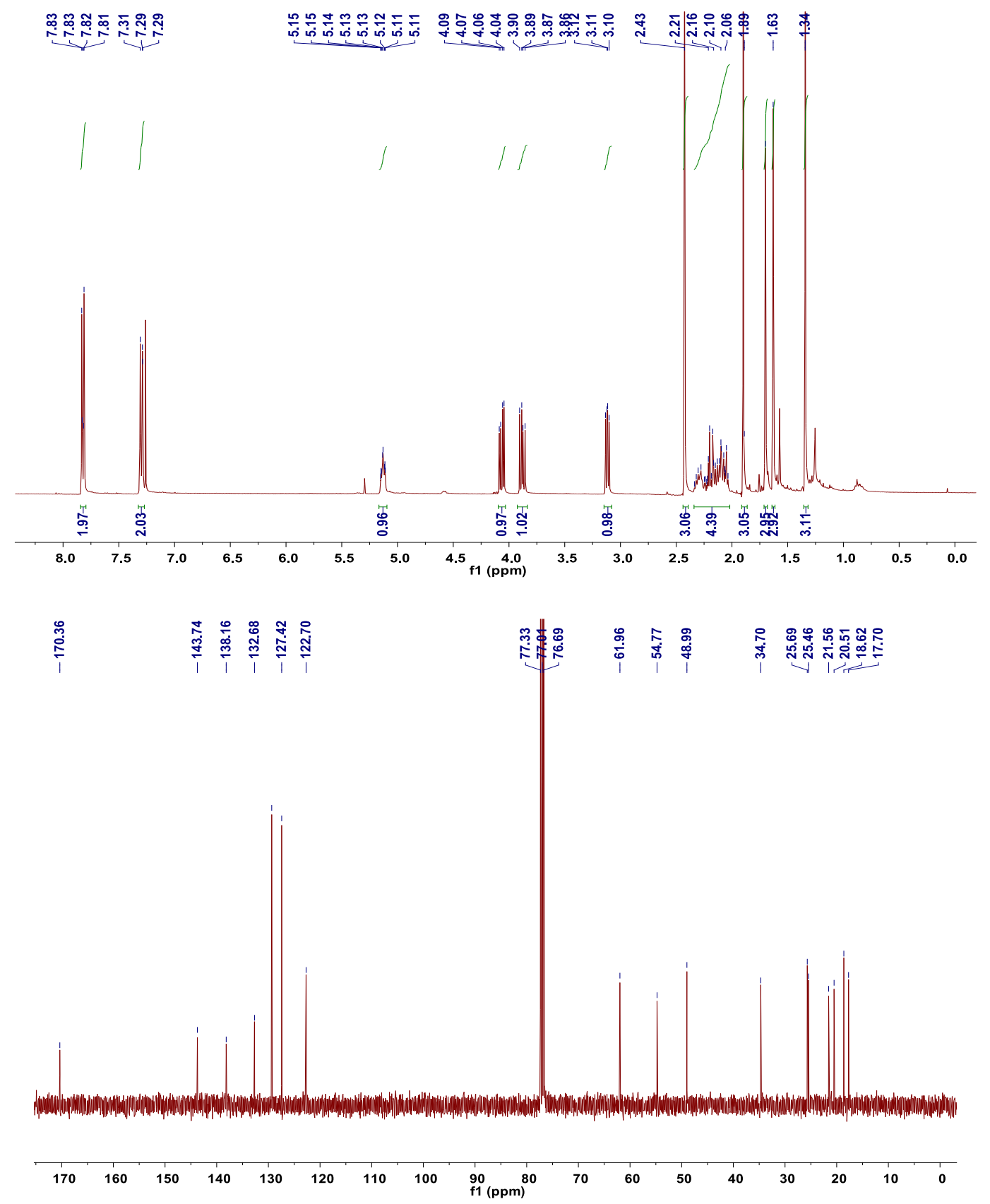




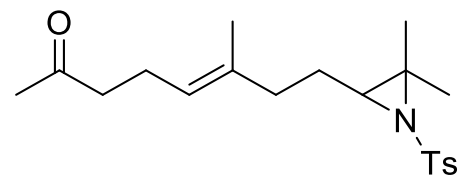

20: ${ }^{1} \mathrm{H}$ NMR $\left(400 \mathrm{MHz}, \mathrm{CDCl}_{3}\right) \delta 7.82-7.77(\mathrm{~m}, 2 \mathrm{H}), 7.28(\mathrm{dd}, J=8.5,0.6 \mathrm{~Hz}, 2 \mathrm{H}), 5.24-5.17$ (m, 1H), $4.52(\mathrm{~d}, J=7.1 \mathrm{~Hz}, 2 \mathrm{H}), 2.78(\mathrm{dd}, J=7.5,5.8 \mathrm{~Hz}, 1 \mathrm{H}), 2.41(\mathrm{~s}, 3 \mathrm{H}), 2.02(\mathrm{~s}, 3 \mathrm{H}), 1.86$ (dddd, $J=19.8,14.5,9.7,6.0 \mathrm{~Hz}, 1 \mathrm{H}), 1.68(\mathrm{~s}, 3 \mathrm{H}), 1.63-1.52(\mathrm{~m}, 4 \mathrm{H}), 1.48-1.37(\mathrm{~m}, 1 \mathrm{H})$, $1.26(\mathrm{~s}, 3 \mathrm{H}) ;{ }^{13} \mathrm{C}$ NMR $\left(101 \mathrm{MHz}, \mathrm{CDCl}_{3}\right) \delta 170.9,143.6,140.7,138.4,129.4,127.4,118.9$, $61.1,52.1,51.8,36.8,26.0,21.5,21.3,21.2,20.9,16.4$.
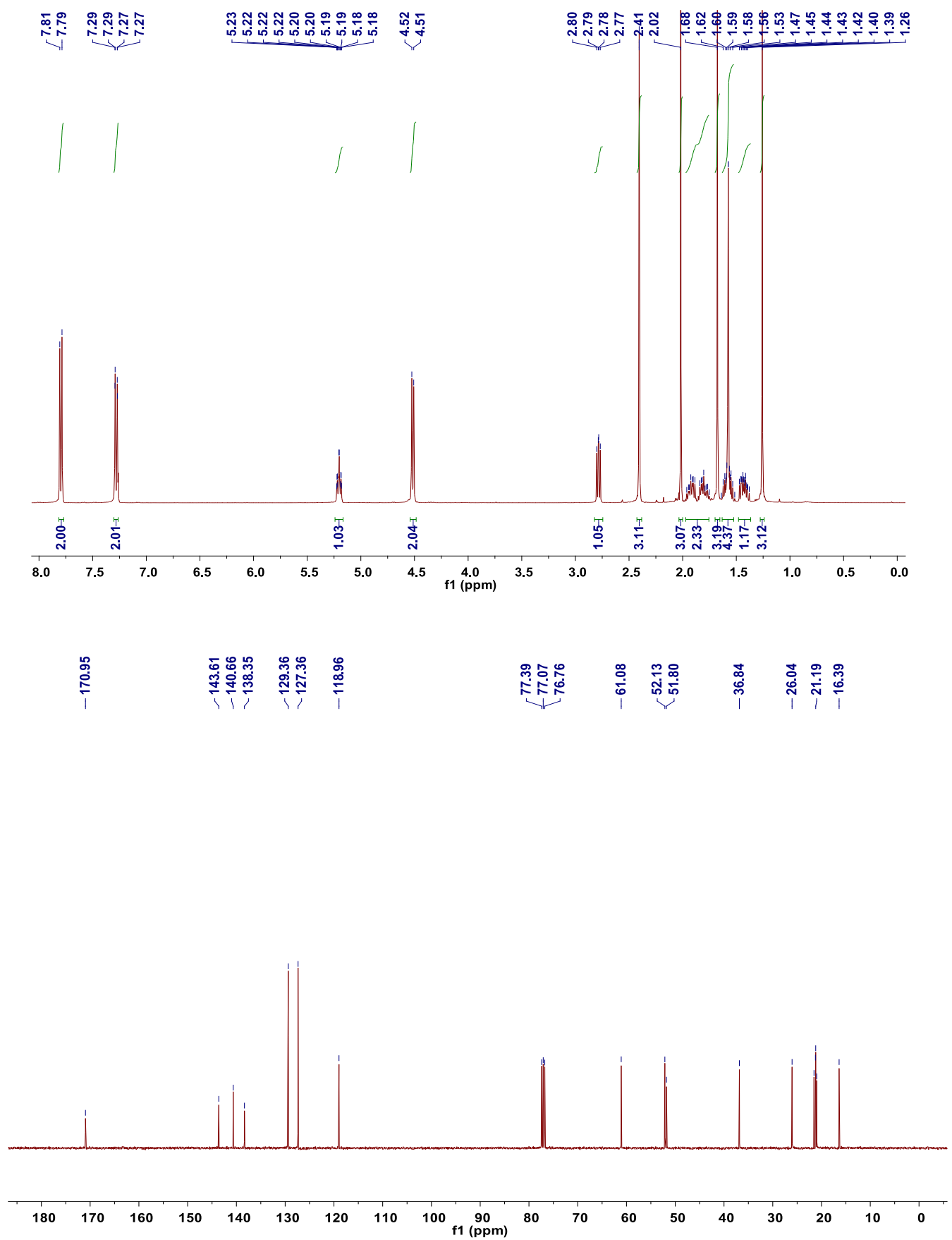
${ }^{1} \mathrm{H}$ and ${ }^{13} \mathrm{C}-\mathrm{NMR}$ Spectra of cyclopropanation products

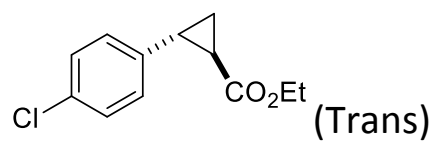

21: ${ }^{1} \mathrm{H}$ NMR $\left(400 \mathrm{MHz}, \mathrm{CDCl}_{3}\right) \delta 7.26-7.21(\mathrm{~m}, 2 \mathrm{H}), 7.05-7.00(\mathrm{~m}, 2 \mathrm{H}), 4.18(\mathrm{tt}, \mathrm{J}=7.2,3.7$ $\mathrm{Hz}, 2 \mathrm{H}$ ), 2.49 (ddd, J = 9.2, 6.5, 4.2 Hz, 1H), 1.86 (ddd, J = 8.5, 5.3, $4.2 \mathrm{~Hz}, 1 \mathrm{H}$ ), 1.60 (ddd, J = 9.2, 5.3, 4.6 Hz, 1H), $1.32-1.22(\mathrm{~m}, 4 \mathrm{H}) ; 13 \mathrm{C} \mathrm{NMR} \mathrm{(101} \mathrm{MHz,} \mathrm{CDCl3)} \delta 173.08,138.64$, $132.17,128.55,127.57,60.79,25.47,24.15,16.98,14.25$.

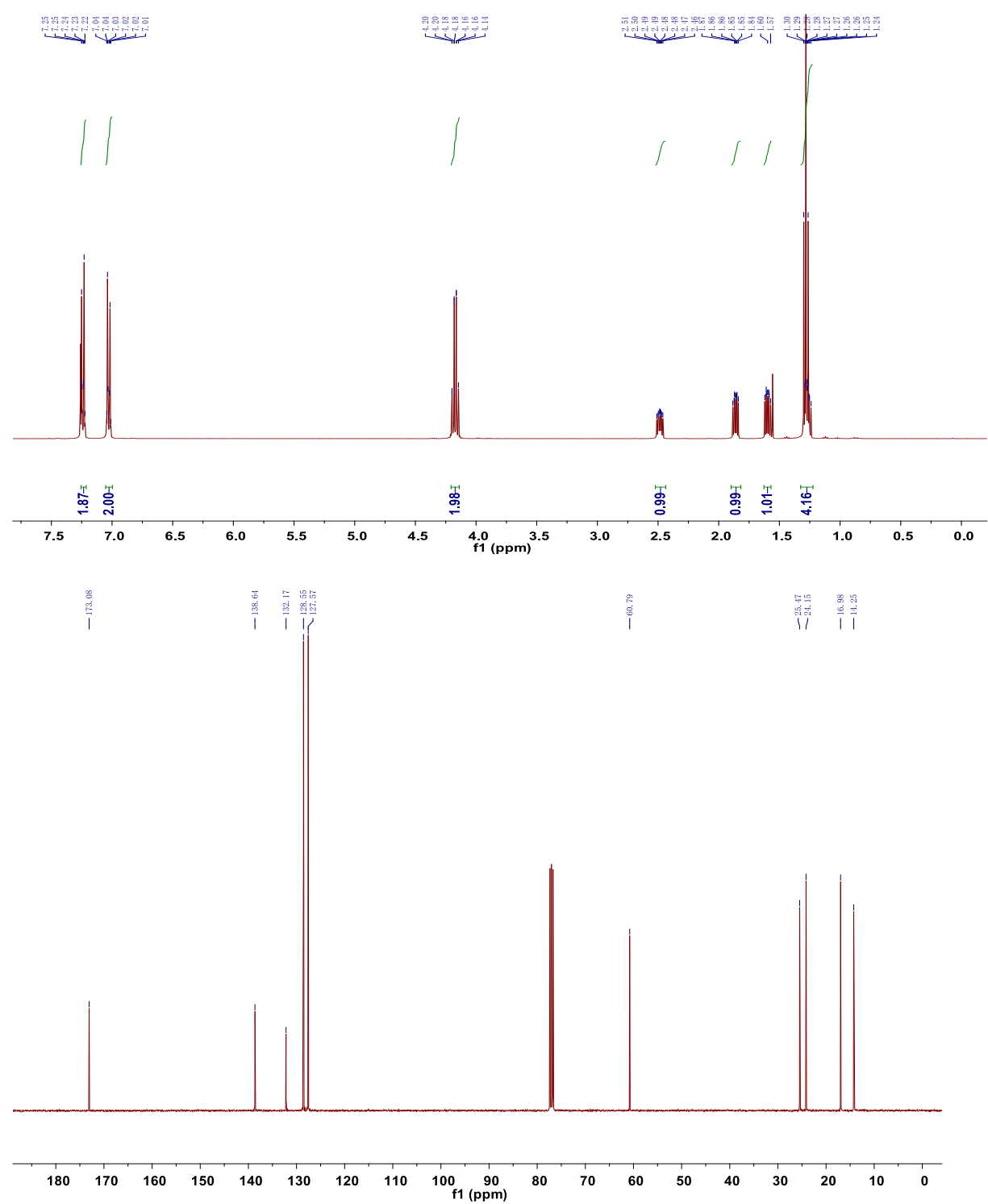




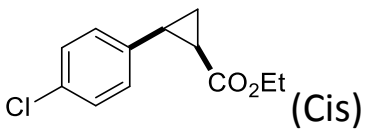

21: ${ }^{1} \mathrm{H}$ NMR $\left(400 \mathrm{MHz}, \mathrm{CDCl}_{3}\right) \delta 7.25-7.17(\mathrm{~m}, 4 \mathrm{H}), 3.90(\mathrm{q}, \mathrm{J}=7.1 \mathrm{~Hz}, 2 \mathrm{H}), 2.52(\mathrm{dd}, \mathrm{J}=16.7$,

$8.7 \mathrm{~Hz}, 1 \mathrm{H}), 2.08(\mathrm{ddd}, \mathrm{J}=9.2,7.9,5.6 \mathrm{~Hz}, 1 \mathrm{H}), 1.70-1.63(\mathrm{~m}, 1 \mathrm{H}), 1.39-1.31(\mathrm{~m}, 1 \mathrm{H}), 1.02$

$(\mathrm{t}, \mathrm{J}=7.1 \mathrm{~Hz}, 3 \mathrm{H}) ;{ }^{13} \mathrm{C}$ NMR $\left(101 \mathrm{MHz}, \mathrm{CDCl}_{3}\right) \delta 170.73,135.10,132.40,130.61,128.01,60.32$, $24.80,21.83,14.08,11.32$.
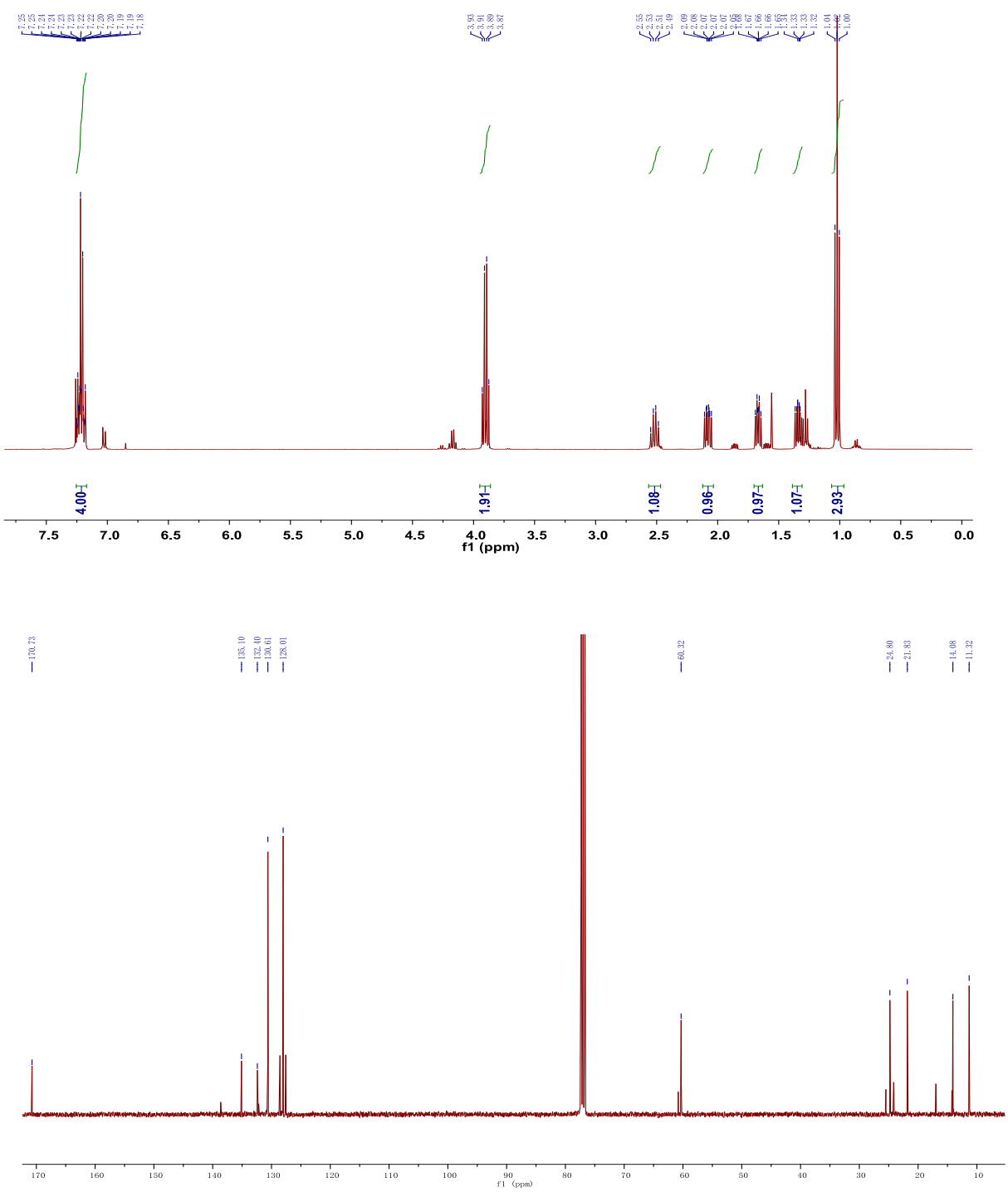

52 


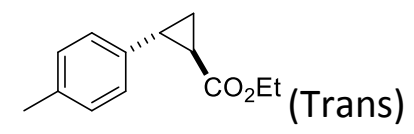

22: ${ }^{1} \mathrm{H}$ NMR $\left(400 \mathrm{MHz}, \mathrm{CDCl}_{3}\right) \delta 7.08-7.10(\mathrm{~m}, 2 \mathrm{H}), 7.04-6.96(\mathrm{~m}, 2 \mathrm{H}), 4.17(\mathrm{q}, \mathrm{J}=7.1 \mathrm{~Hz}$, 2H), 2.50 (ddd, J = 9.3, 6.5, 4.2 Hz, 1H), $2.32(\mathrm{~s}, 3 \mathrm{H}$ ), 1.87 (ddd, J = 8.4, 5.3, 4.2 Hz, $1 \mathrm{H}$ ), 1.57 (ddd, J = 9.3, 5.3, $4.5 \mathrm{~Hz}, 1 \mathrm{H}), 1.33-1.24(\mathrm{~m}, 4 \mathrm{H}) ;{ }^{13} \mathrm{C} \mathrm{NMR}\left(101 \mathrm{MHz}, \mathrm{CDCl}_{3}\right) \delta 173.50$, $137.05,136.07,129.12,126.11,60.63,25.92,24.03,20.97,16.91,14.27$.

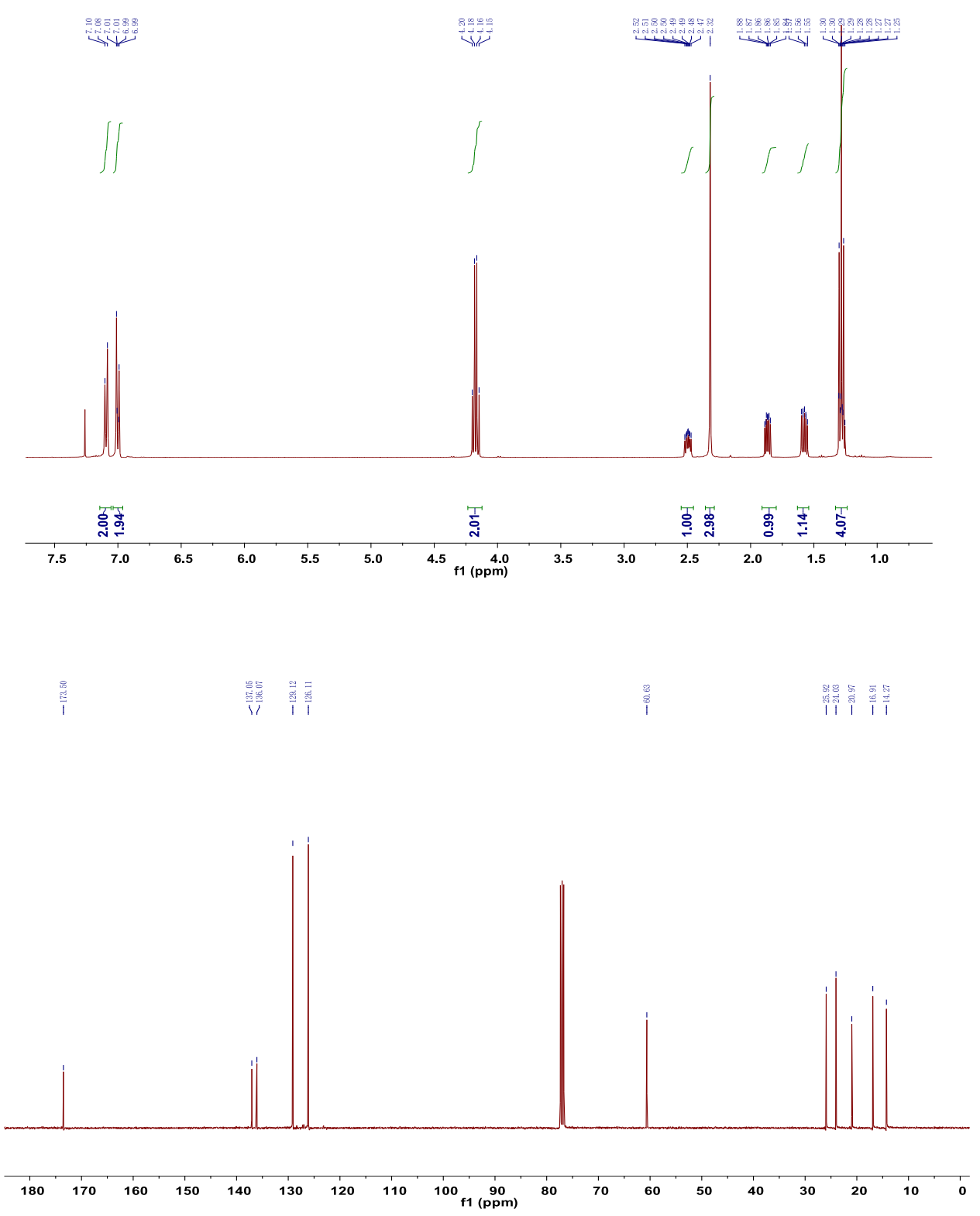




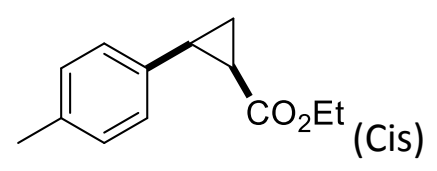

22: ${ }^{1} \mathrm{H}$ NMR $\left(400 \mathrm{MHz}, \mathrm{CDCl}_{3}\right) \delta 7.15(\mathrm{~d}, J=8.0 \mathrm{~Hz}, 2 \mathrm{H}), 7.07(\mathrm{~d}, J=8.0 \mathrm{~Hz}, 2 \mathrm{H}), 3.89(\mathrm{q}, J=7.1$ $\mathrm{Hz}, 2 \mathrm{H}), 2.54(\mathrm{dd}, J=16.8,8.6 \mathrm{~Hz}, 1 \mathrm{H}), 2.30(\mathrm{~s}, 3 \mathrm{H}), 2.05$ (ddd, $J=9.2,7.8,5.6 \mathrm{~Hz}, 1 \mathrm{H}), 1.68$ $(\mathrm{dt}, J=7.5,5.3 \mathrm{~Hz}, 1 \mathrm{H}), 1.34-1.26(\mathrm{~m}, 1 \mathrm{H}), 1.01(\mathrm{t}, J=7.1 \mathrm{~Hz}, 3 \mathrm{H}) ;{ }^{13} \mathrm{C} \mathrm{NMR}\left(101 \mathrm{MHz}, \mathrm{CDCl}_{3}\right)$ $\delta 171.06,136.10,133.43,129.13,128.59,60.13,25.20,21.69,21.08,14.07,11.19$.

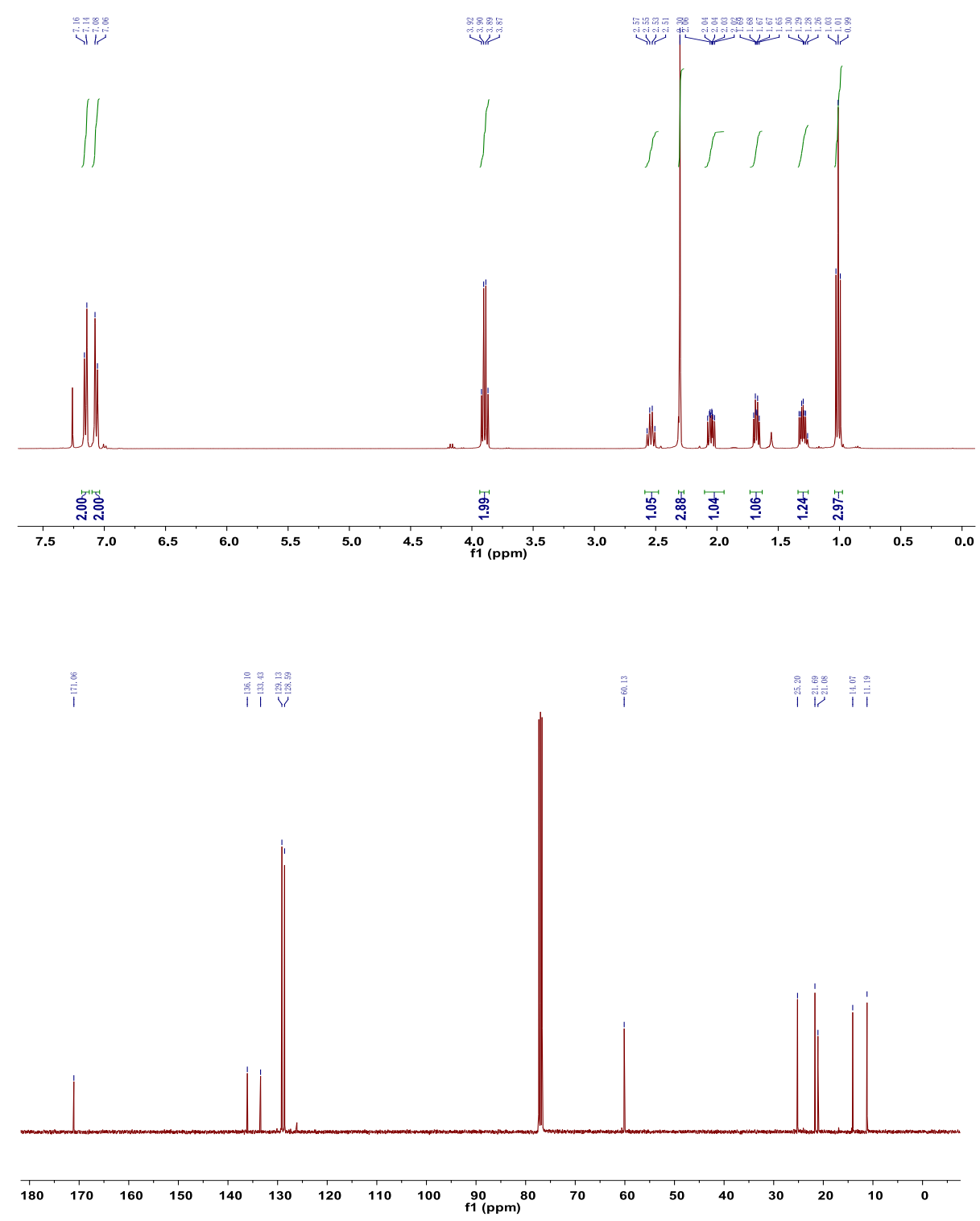


<smiles>CCOC(=O)C1C[C@H]1c1cccc(OC)c1</smiles>

23: ${ }^{1} \mathrm{H}$ NMR $\left(300 \mathrm{MHz}, \mathrm{CDCl}_{3}\right) \delta 7.19(\mathrm{t}, J=7.9 \mathrm{~Hz}, 1 \mathrm{H}), 6.71(\mathrm{ddd}, J=16.1,8.1,1.9 \mathrm{~Hz}, 3 \mathrm{H})$,

$4.17(q, J=7.1 \mathrm{~Hz}, 2 \mathrm{H}), 3.79(\mathrm{~s}, 3 \mathrm{H}), 2.49$ (ddd, $J=10.3,6.5,4.2 \mathrm{~Hz}, 1 \mathrm{H}), 1.90(\mathrm{dt}, J=12.6,4.8$

$\mathrm{Hz}, 1 \mathrm{H}), 1.58(\mathrm{dt}, J=9.6,4.9 \mathrm{~Hz}, 1 \mathrm{H}), 1.29(\mathrm{~m}, 4 \mathrm{H}) ;{ }^{13} \mathrm{C} \mathbf{N M R}\left(75 \mathrm{MHz}, \mathrm{CDCl}_{3}\right) \delta 173.35,159.75$,

$141.82,129.46,118.47,112.16,111.76,60.70,55.21,26.17,24.17,17.05,14.26$.
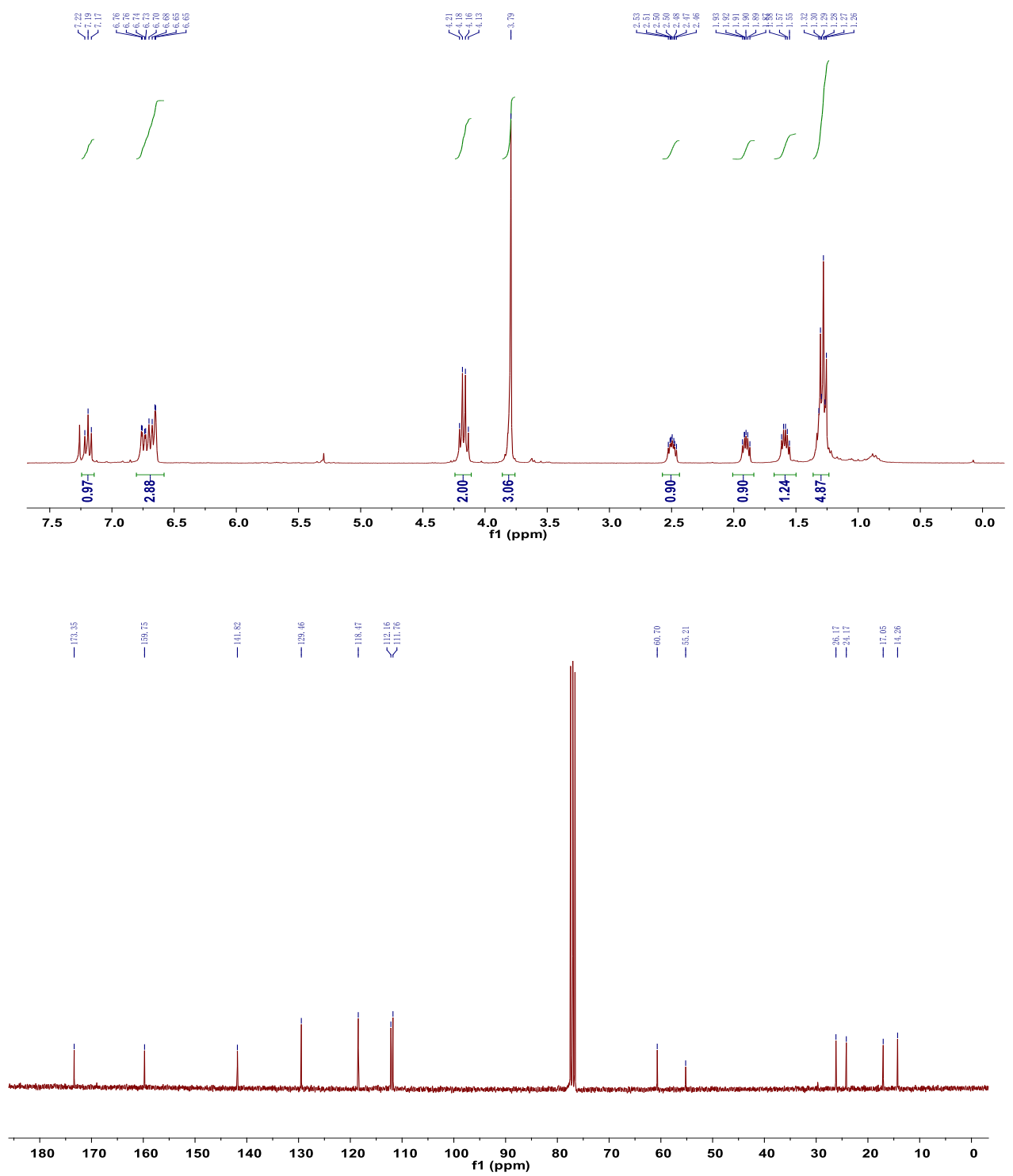

55 


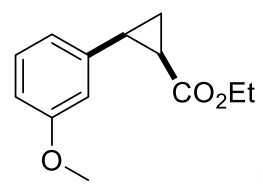

(Cis)

23: ${ }^{1} \mathrm{H}$ NMR $\left(400 \mathrm{MHz}, \mathrm{CDCl}_{3}\right) \delta 7.17(\mathrm{t}, J=7.9 \mathrm{~Hz}, 1 \mathrm{H}), 6.85$ (ddd, $\left.J=11.3,6.0,1.4 \mathrm{~Hz}, 2 \mathrm{H}\right)$, $6.74(\mathrm{dd}, J=8.2,2.6 \mathrm{~Hz}, 1 \mathrm{H}), 3.90(\mathrm{q}, J=7.1 \mathrm{~Hz}, 2 \mathrm{H}), 3.78(\mathrm{~s}, 3 \mathrm{H}), 2.55(\mathrm{dd}, J=16.7,8.7 \mathrm{~Hz}$, 1H), 2.07 (ddd, $J=9.3,7.8,5.7 \mathrm{~Hz}, 1 \mathrm{H}$ ), 1.69 (dt, $J=7.5,5.4 \mathrm{~Hz}, 1 \mathrm{H}), 1.31$ (ddd, $J=8.6,7.9$, $5.0 \mathrm{~Hz}, 1 \mathrm{H}), 1.00(\mathrm{t}, J=7.1 \mathrm{~Hz}, 3 \mathrm{H}) ;{ }^{13} \mathrm{C}$ NMR $\left(101 \mathrm{MHz}, \mathrm{CDCl}_{3}\right) \delta 170.92,159.25,138.24$, $128.80,121.72,114.98,112.22,60.18,55.13,25.46,21.79,14.05,11.23$.
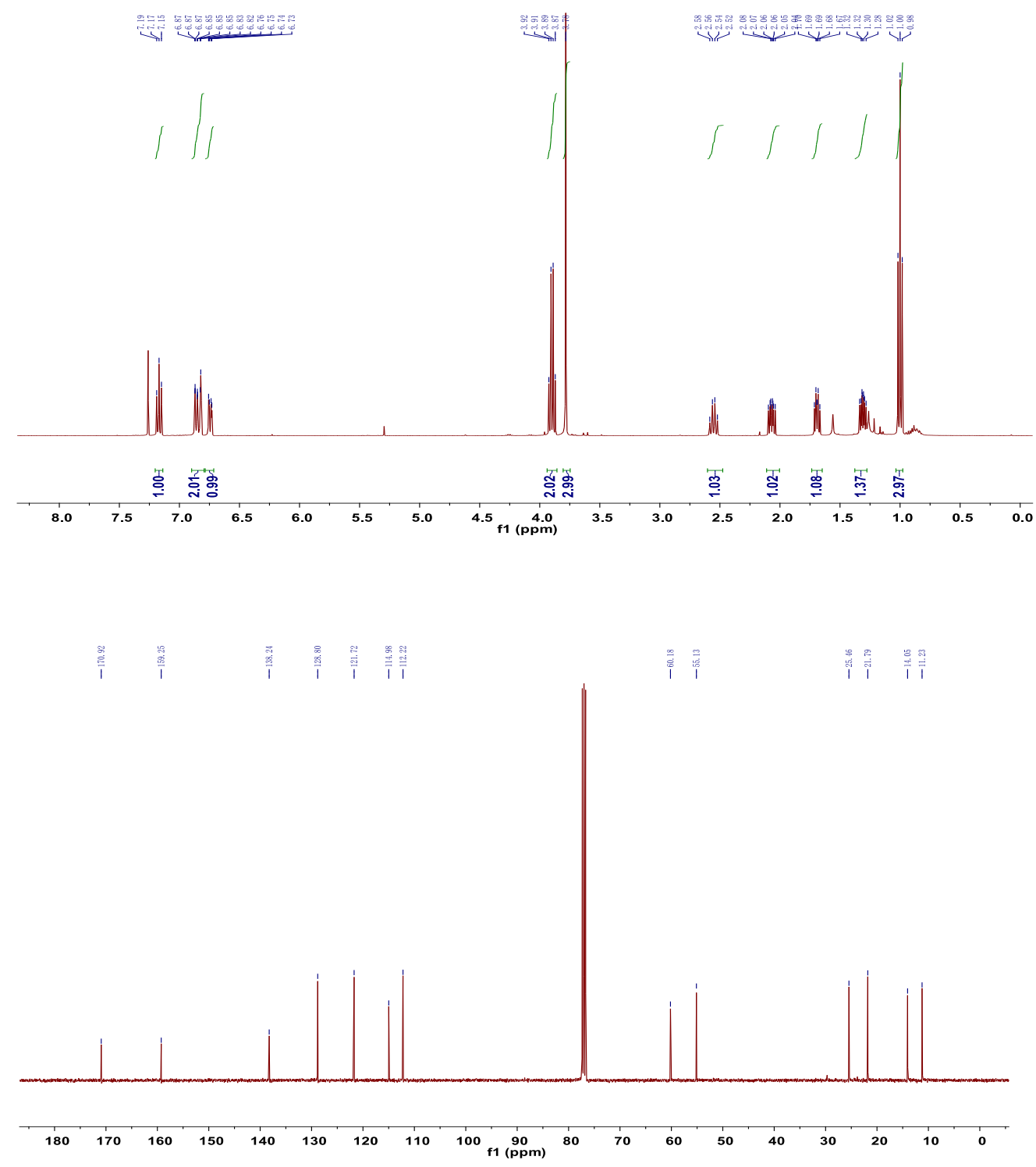


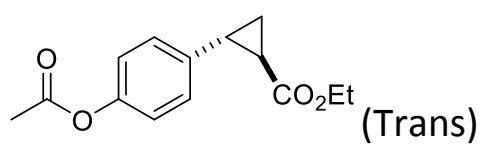

24: ${ }^{1} \mathrm{H}$ NMR $\left(400 \mathrm{MHz}, \mathrm{CDCl}_{3}\right) \delta 7.14-7.08(\mathrm{~m}, 2 \mathrm{H}), 7.03-6.97(\mathrm{~m}, 2 \mathrm{H}), 4.17(\mathrm{q}, J=7.1 \mathrm{~Hz}$, 2H), 2.51 (ddd, $J=9.3,6.5,4.2 \mathrm{~Hz}, 1 \mathrm{H}$ ), $2.28(\mathrm{~s}, 3 \mathrm{H}$ ), 1.87 (ddd, $J=8.4,5.3,4.2 \mathrm{~Hz}, 1 \mathrm{H}$ ), 1.59 (ddd, $J=9.3,5.3,4.6 \mathrm{~Hz}, 1 \mathrm{H}), 1.36-1.22(\mathrm{~m}, 4 \mathrm{H}) ;{ }^{13} \mathrm{C}$ NMR $\left(101 \mathrm{MHz}, \mathrm{CDCl}_{3}\right) \delta 173.24$, $169.50,149.22,137.69,127.25,121.55,60.73,25.61,24.09,21.08,16.91,14.25$.

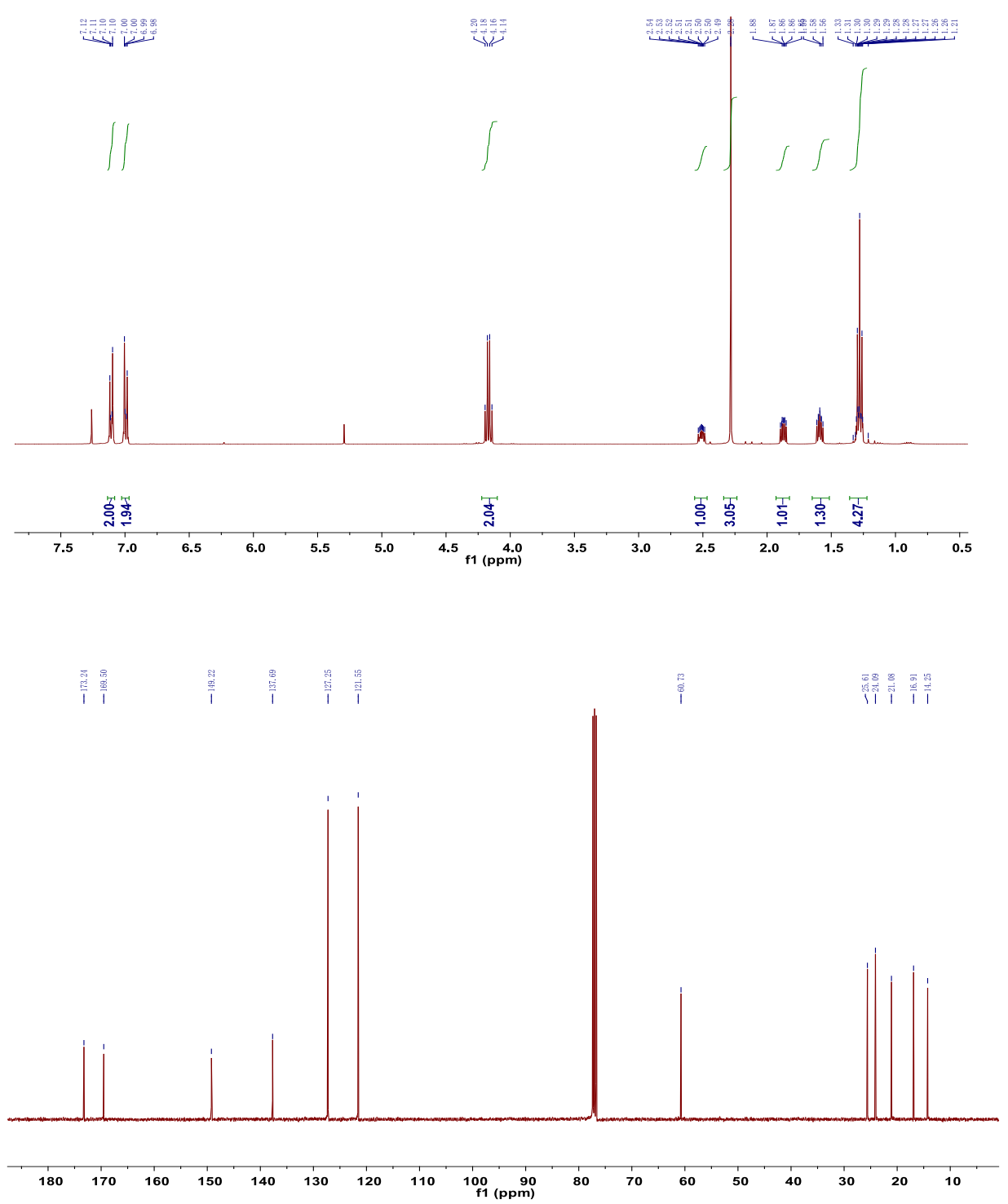




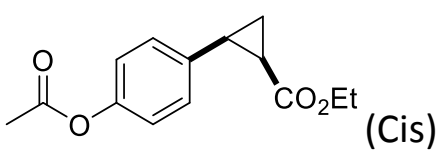

24: ${ }^{1} \mathrm{H}$ NMR $\left(400 \mathrm{MHz}, \mathrm{CDCl}_{3}\right) \delta 7.29-7.24(\mathrm{~m}, 2 \mathrm{H}), 7.01-6.96(\mathrm{~m}, 2 \mathrm{H}), 3.94-3.83$ (m, 2H), $2.54(\mathrm{dd}, J=16.7,8.7 \mathrm{~Hz}, 1 \mathrm{H}), 2.27(\mathrm{~s}, 3 \mathrm{H}), 2.13-2.02(\mathrm{~m}, 1 \mathrm{H}), 1.72-1.64$ (m, 1H), 1.33 (ddd, $J=8.7,7.9,5.1 \mathrm{~Hz}, 1 \mathrm{H}), 0.98(\mathrm{t}, J=7.1 \mathrm{~Hz}, 3 \mathrm{H}) ;{ }^{13} \mathrm{C}$ NMR $(101 \mathrm{MHz}$ $\left.\mathrm{CDCl}_{3}\right) \delta 170.82,169.39,149.37,134.19,130.21,120.93,60.25,24.84,21.90,21.11$, $14.00,11.33$.

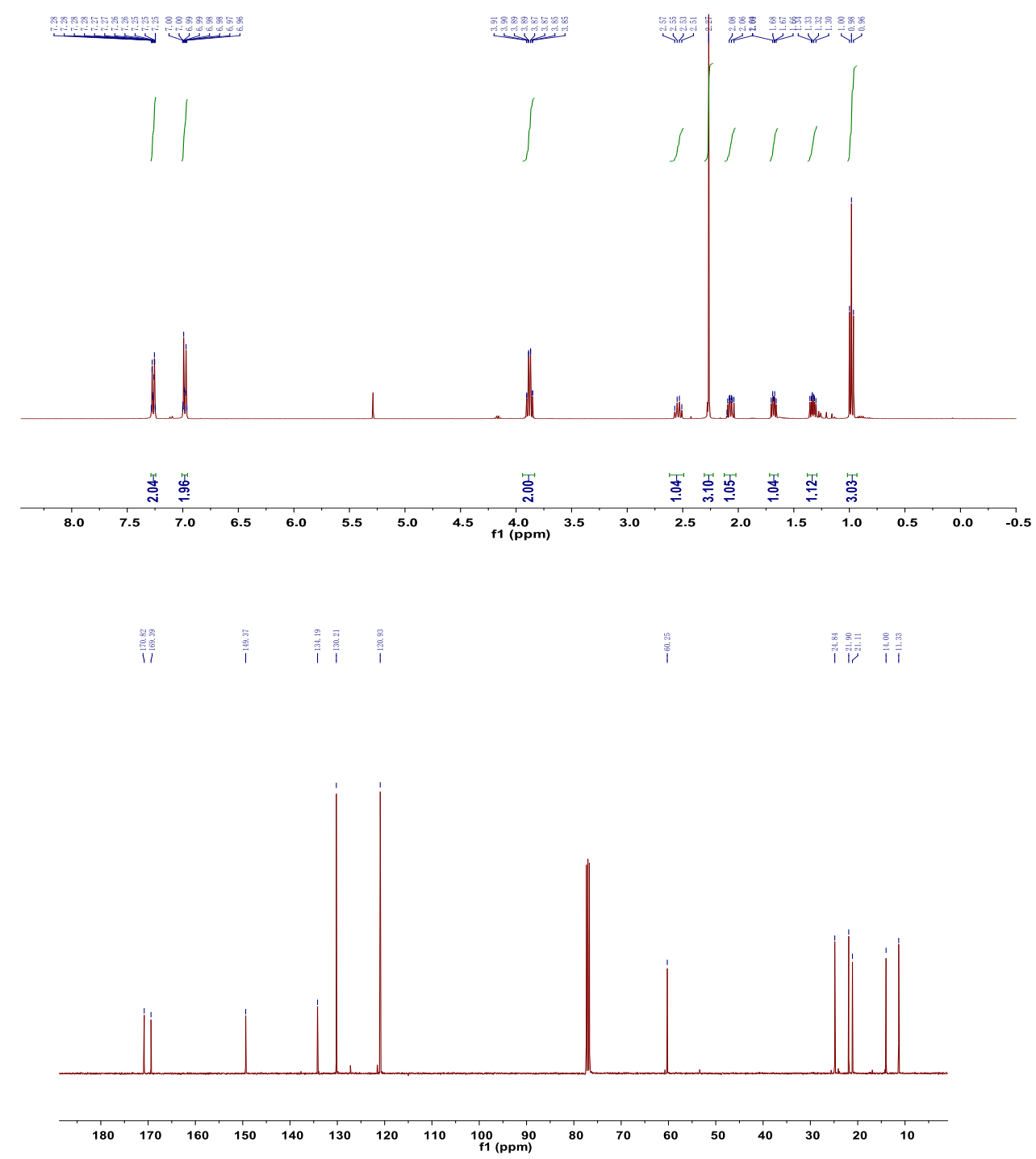




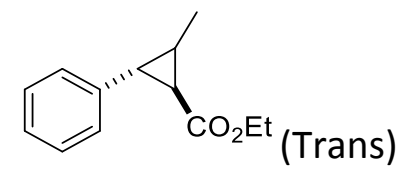

25: ${ }^{1} \mathrm{H}$ NMR $\left(400 \mathrm{MHz}, \mathrm{CDCl}_{3}\right) \delta 7.31-7.24(\mathrm{~m}, 2 \mathrm{H}), 7.22-7.16(\mathrm{~m}, 1 \mathrm{H}), 7.09(\mathrm{dd}, J=5.2,3.3$ $\mathrm{Hz}, 2 \mathrm{H}), 4.18(\mathrm{qd}, J=7.1,1.9 \mathrm{~Hz}, 2 \mathrm{H}), 2.42(\mathrm{dd}, J=6.4,5.1 \mathrm{~Hz}, 1 \mathrm{H}), 2.02(\mathrm{dd}, J=9.2,5.0 \mathrm{~Hz}$, 1H), $1.72-1.65(\mathrm{~m}, 1 \mathrm{H}), 1.36(\mathrm{~d}, J=6.2 \mathrm{~Hz}, 3 \mathrm{H}), 1.29(\mathrm{t}, J=7.1 \mathrm{~Hz}, 3 \mathrm{H}) ;{ }^{13} \mathrm{C}$ NMR $(101 \mathrm{MHz}$, $\left.\mathrm{CDCl}_{3}\right) \delta 171.60,140.62,128.43,126.23,126.03,60.44,32.35,29.41,25.51,14.38,12.02$.

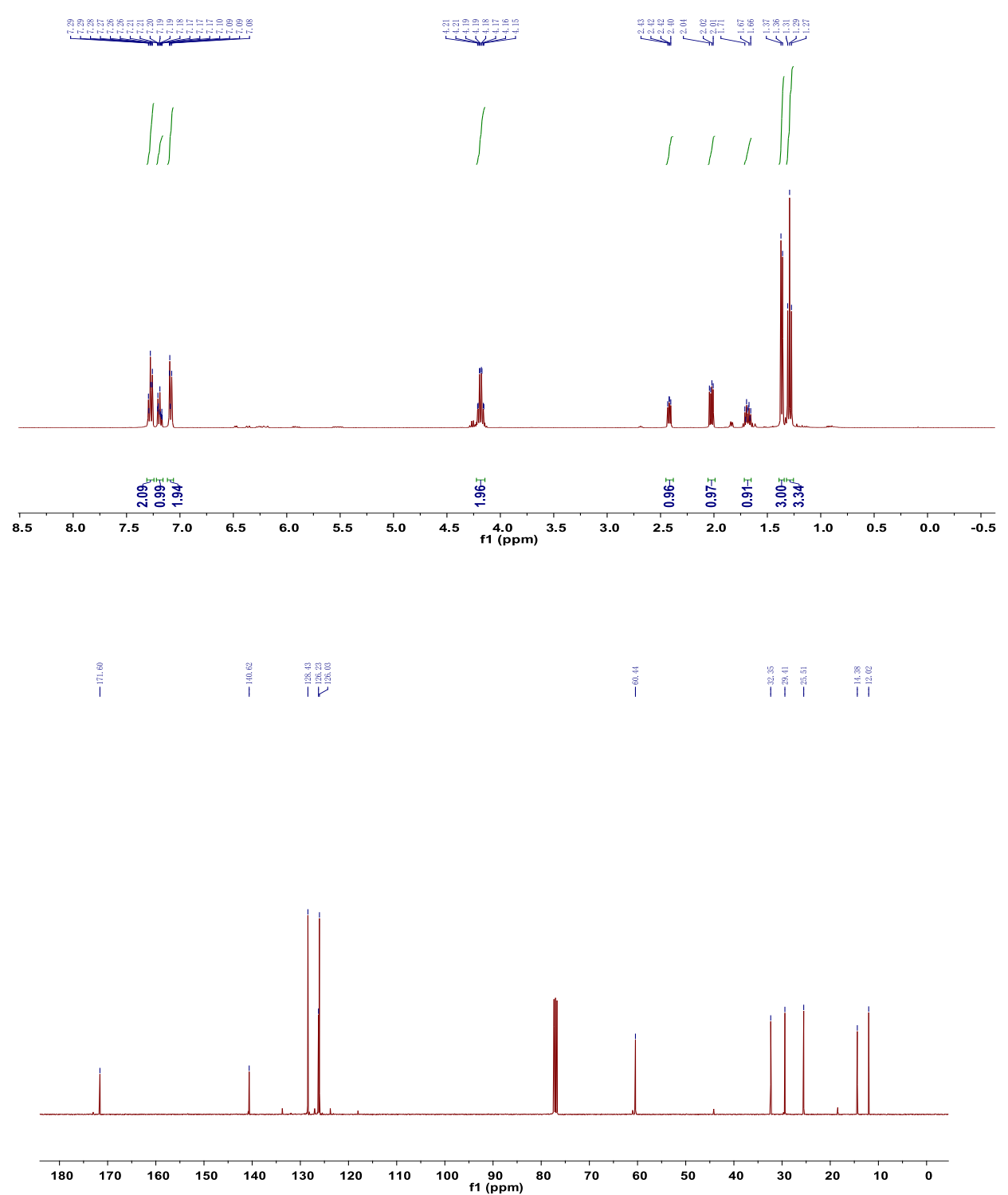




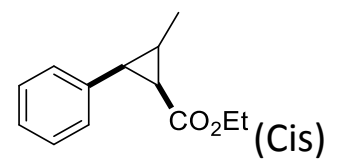

25: ${ }^{1} \mathrm{H}$ NMR $\left(400 \mathrm{MHz}, \mathrm{CDCl}_{3}\right) \delta 7.26-7.22(\mathrm{~m}, 4 \mathrm{H}), 7.21-7.15(\mathrm{~m}, 1 \mathrm{H}), 3.87(\mathrm{q}, J=7.1 \mathrm{~Hz}$, 2H), $2.35(\mathrm{dd}, J=9.3,6.9 \mathrm{~Hz}, 1 \mathrm{H}), 2.13-2.02(\mathrm{~m}, 1 \mathrm{H}), 1.82(\mathrm{dd}, J=9.3,5.1 \mathrm{~Hz}, 1 \mathrm{H}), 1.28(\mathrm{~d}, J$

$=6.1 \mathrm{~Hz}, 3 \mathrm{H}), 0.98(\mathrm{t}, J=7.1 \mathrm{~Hz}, 3 \mathrm{H}) ;{ }^{13} \mathrm{C}$ NMR $\left(101 \mathrm{MHz}, \mathrm{CDCl}_{3}\right) \delta 170.85,136.77,129.12$, $127.83,126.50,60.06,34.17,30.09,19.65,17.71,14.03$.
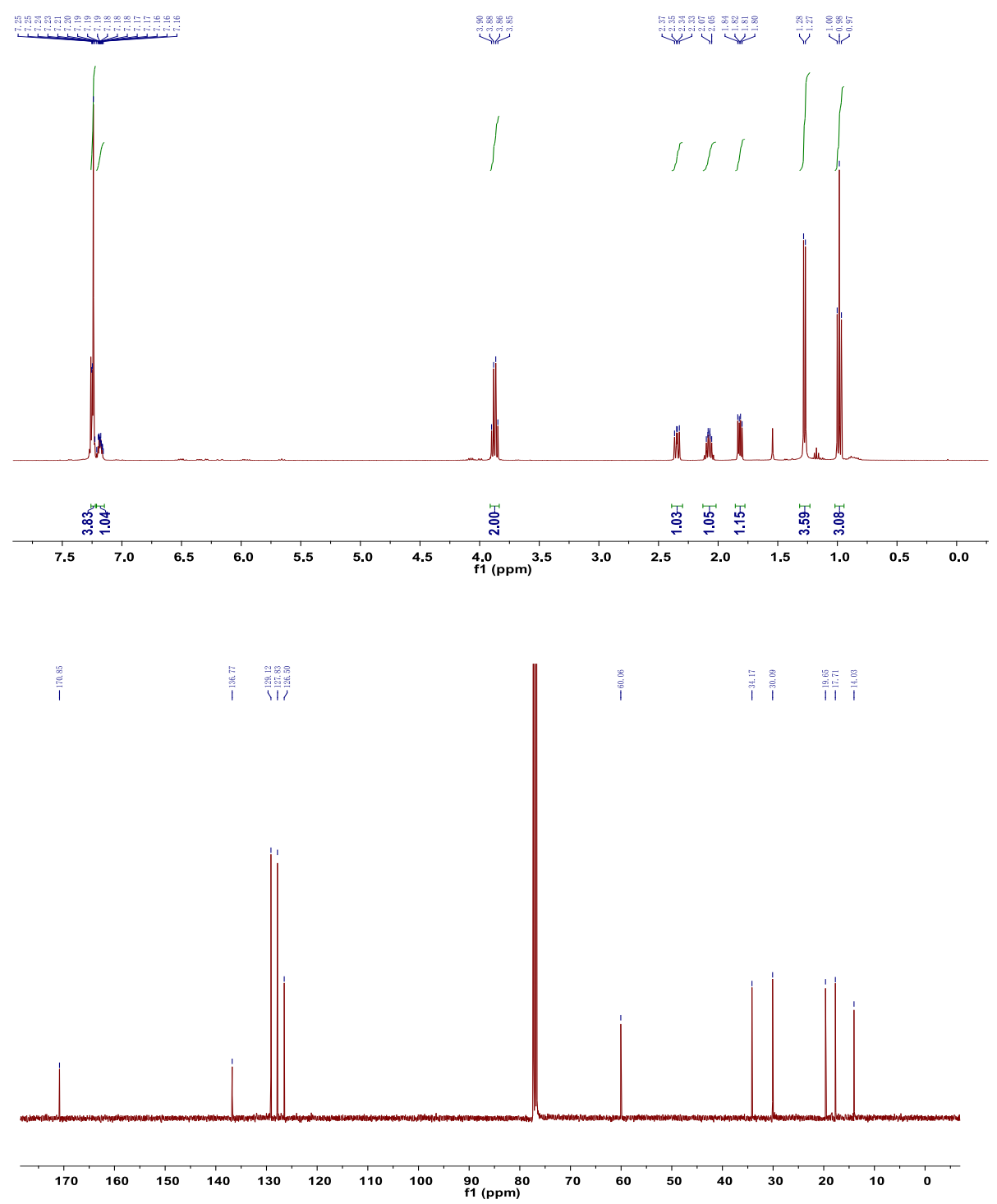


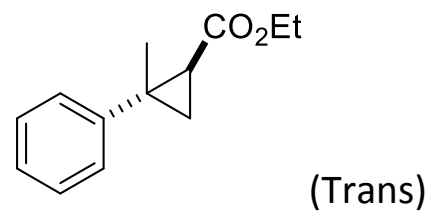

26: ${ }^{1} \mathrm{H}$ NMR $\left(400 \mathrm{MHz}, \mathrm{CDCl}_{3}\right) \delta 7.35-7.28(\mathrm{~m}, 4 \mathrm{H}), 7.25-7.19(\mathrm{~m}, 1 \mathrm{H}), 4.28-4.16(\mathrm{~m}, 2 \mathrm{H})$, $1.99(\mathrm{dd}, J=8.3,6.0 \mathrm{~Hz}, 1 \mathrm{H}), 1.55(\mathrm{~s}, 3 \mathrm{H}), 1.45(\mathrm{ddd}, J=13.0,7.1,4.7 \mathrm{~Hz}, 2 \mathrm{H}), 1.32(\mathrm{t}, J=7.1$ $\mathrm{Hz}, 3 \mathrm{H}) ;{ }^{13} \mathrm{C}$ NMR $\left(101 \mathrm{MHz}, \mathrm{CDCl}_{3}\right) \delta 172.15,145.93,128.45,127.29,126.44,60.48,30.56$, $27.89,20.79,19.89,14.43$.

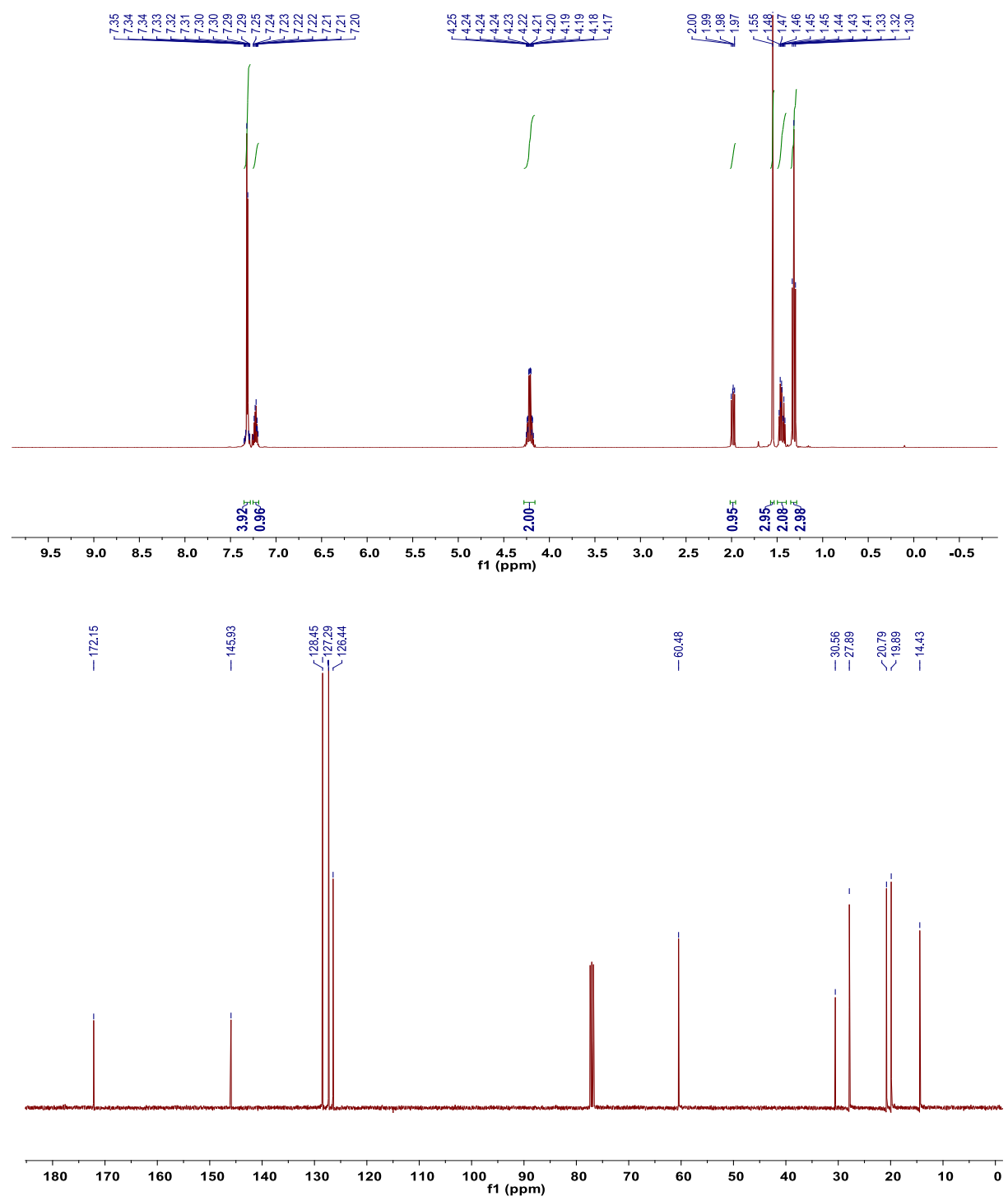




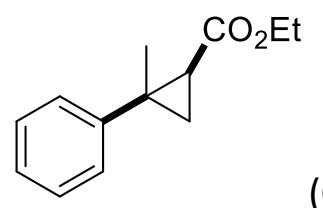

(Cis)

26: ${ }^{1} \mathrm{H}$ NMR $\left(400 \mathrm{MHz}, \mathrm{CDCl}_{3}\right) \delta 7.32-7.24(\mathrm{~m}, 4 \mathrm{H}), 7.20(\mathrm{dqd}, \mathrm{J}=4.8,4.1,2.8 \mathrm{~Hz}, 1 \mathrm{H}), 3.91-$ $3.77(\mathrm{~m}, 2 \mathrm{H}), 1.91(\mathrm{dd}, \mathrm{J}=7.8,5.4 \mathrm{~Hz}, 1 \mathrm{H}), 1.81-1.75(\mathrm{~m}, 1 \mathrm{H}), 1.47(\mathrm{~s}, 3 \mathrm{H}), 1.15(\mathrm{dd}, \mathrm{J}=7.8$, 4.6 Hz, 1H), $0.95(\mathrm{t}, \mathrm{J}=7.1 \mathrm{~Hz}, 3 \mathrm{H}) ;{ }^{13} \mathrm{C}$ NMR $\left(101 \mathrm{MHz}, \mathrm{CDCl}_{3}\right) \delta 171.22,141.90,128.76$, $128.14,126.62,60.05,32.03,28.56,28.55,19.43,13.96$.

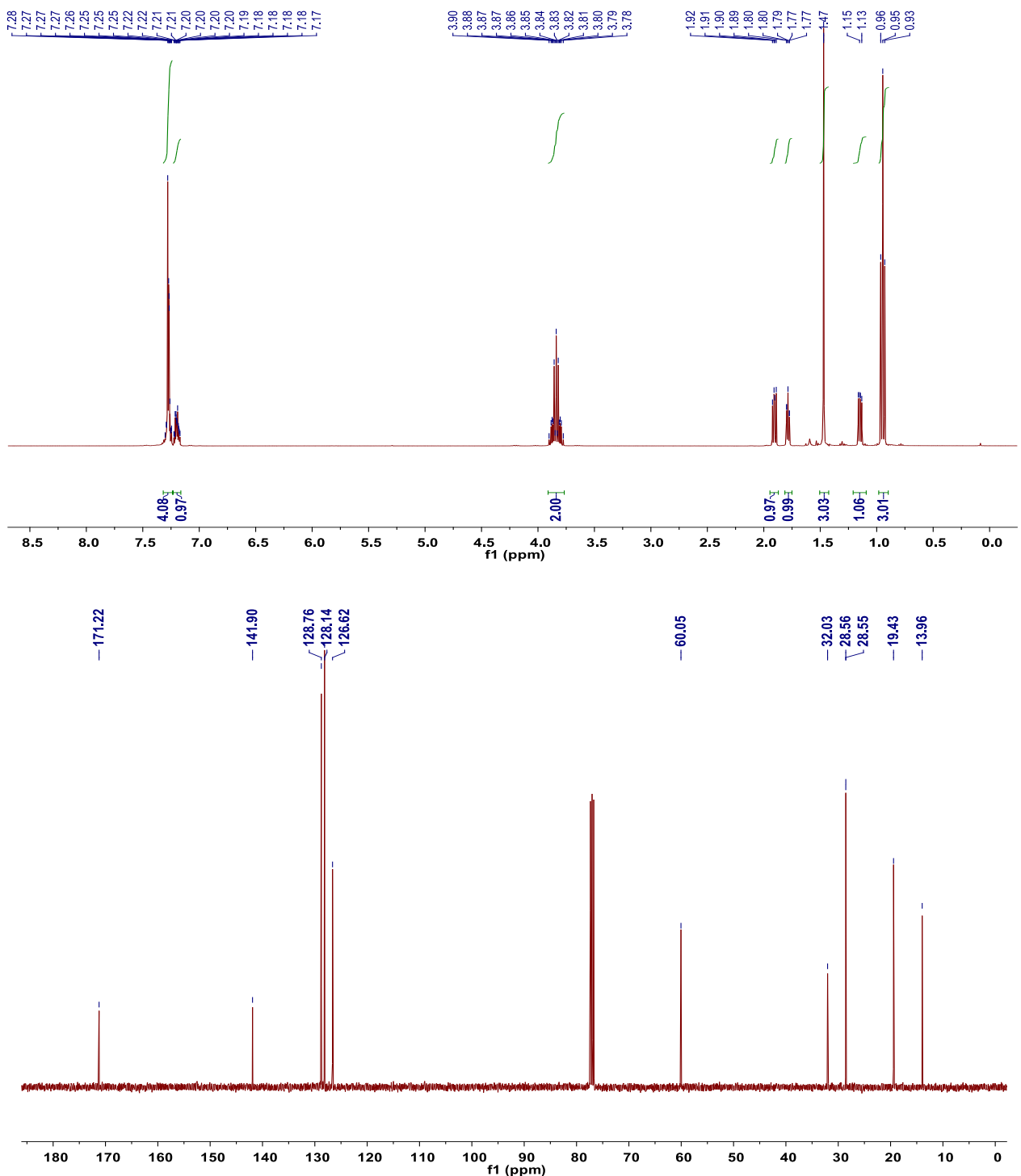




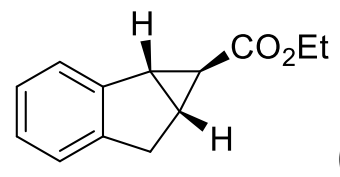

(Trans)

27: ${ }^{1} \mathrm{H}$ NMR $\left(400 \mathrm{MHz}, \mathrm{CDCl}_{3}\right) \delta 7.38-7.31(\mathrm{~m}, 1 \mathrm{H}), 7.21-7.10(\mathrm{~m}, 3 \mathrm{H}), 4.16(\mathrm{q}, J=7.1 \mathrm{~Hz}$, 2H), $3.28(\mathrm{dd}, J=17.6,6.4 \mathrm{~Hz}, 1 \mathrm{H}), 3.12-3.01(\mathrm{~m}, 1 \mathrm{H}), 2.96(\mathrm{ddd}, J=6.5,2.4,1.4 \mathrm{~Hz}, 1 \mathrm{H})$, $2.45(\mathrm{tdd}, J=6.5,3.3,0.6 \mathrm{~Hz}, 1 \mathrm{H}), 1.28(\mathrm{t}, J=7.1 \mathrm{~Hz}, 3 \mathrm{H}), 1.24-1.19(\mathrm{~m}, 1 \mathrm{H}) ;{ }^{13} \mathrm{C}$ NMR $(101$ $\left.\mathrm{MHz}, \mathrm{CDCl}_{3}\right) \delta 172.69,143.65,141.76,126.38,126.33,125.21,123.93,60.53,35.36,34.32$, $30.77,26.36,14.28$.

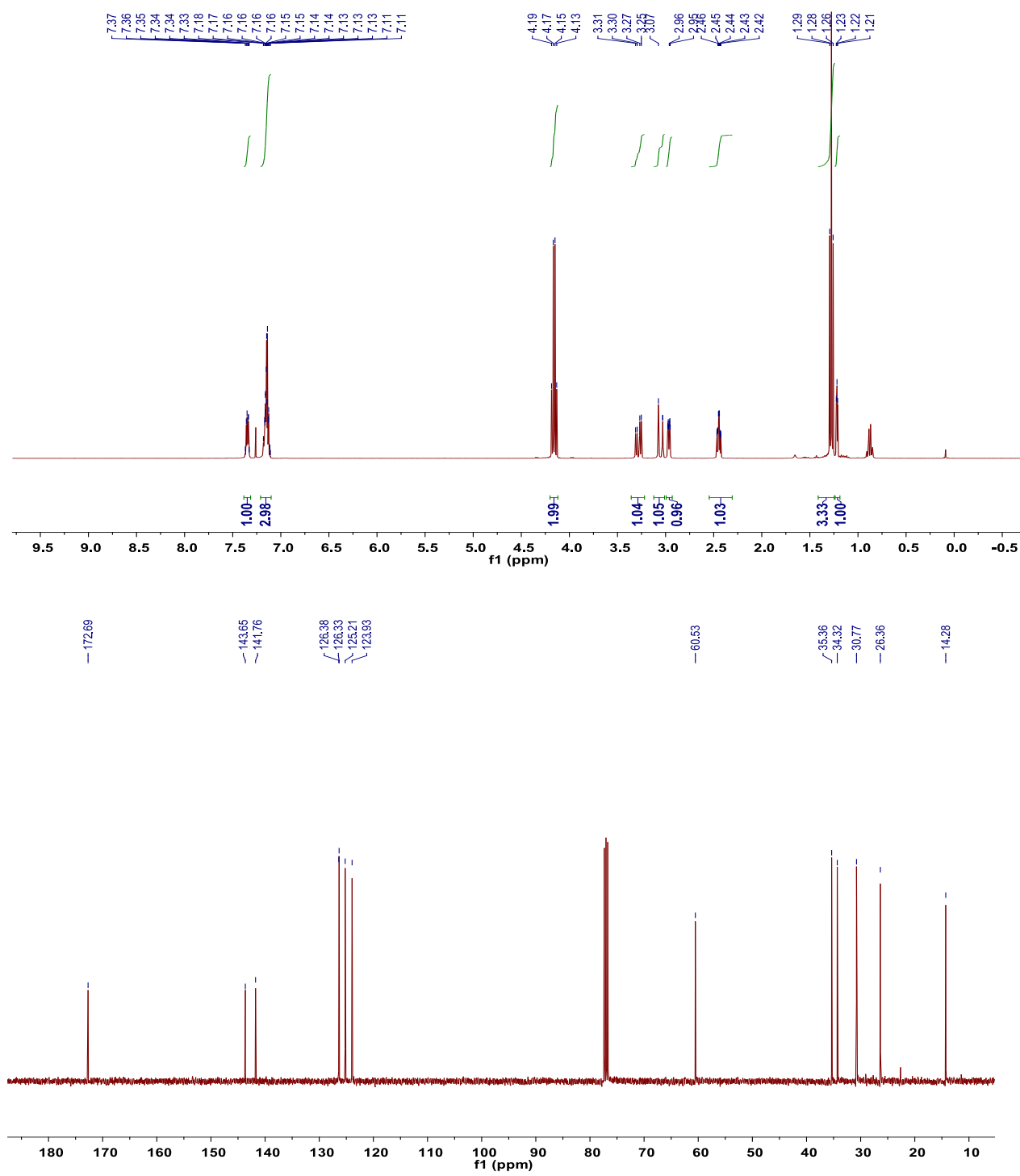




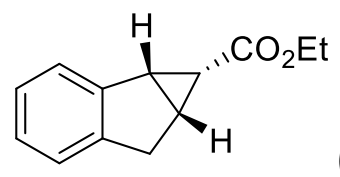

(Cis)

27: ${ }^{1} \mathrm{H}$ NMR $\left(400 \mathrm{MHz}, \mathrm{CDCl}_{3}\right) \delta 7.36-7.27(\mathrm{~m}, 1 \mathrm{H}), 7.18-7.08(\mathrm{~m}, 3 \mathrm{H}), 3.83(\mathrm{q}, \mathrm{J}=7.1 \mathrm{~Hz}$, $2 \mathrm{H}), 3.36(\mathrm{~d}, \mathrm{~J}=17.3 \mathrm{~Hz}, 1 \mathrm{H}), 3.21(\mathrm{dd}, \mathrm{J}=17.2,6.8 \mathrm{~Hz}, 1 \mathrm{H}), 2.99-2.91(\mathrm{~m}, 1 \mathrm{H}), 2.27(\mathrm{dtd}, \mathrm{J}=$ 7.8, 7.0, 0.9 Hz, 1H), $2.01(\mathrm{t}, \mathrm{J}=8.2 \mathrm{~Hz}, 1 \mathrm{H}), 0.95(\mathrm{t}, \mathrm{J}=7.1 \mathrm{~Hz}, 3 \mathrm{H}) ;{ }^{13} \mathrm{C}$ NMR $\left(101 \mathrm{MHz}, \mathrm{CDCl}_{3}\right)$ $\delta 169.56,144.67,139.88,126.47,125.98,124.64,123.90,59.87,32.43,31.64,24.65,23.55$, 13.94.

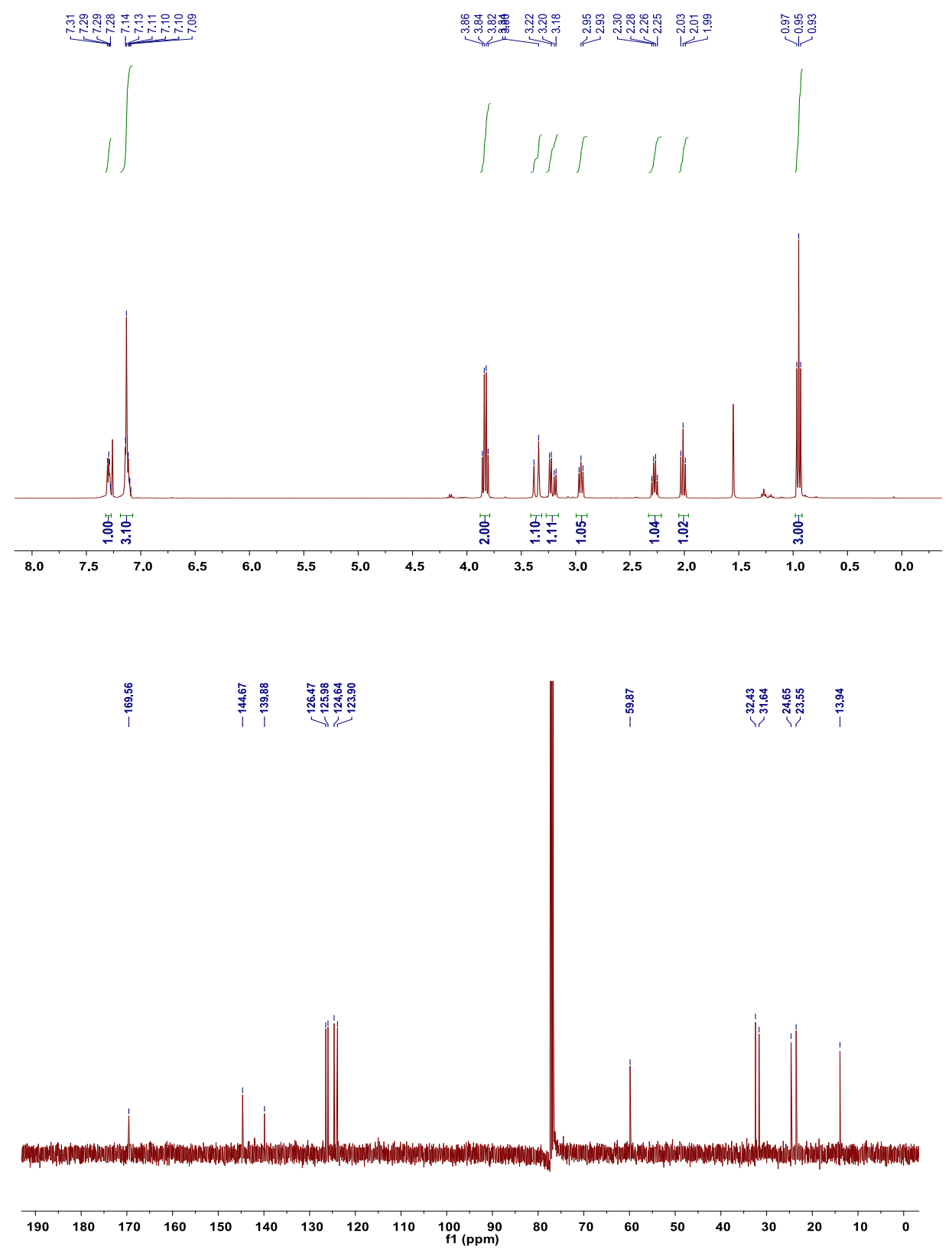




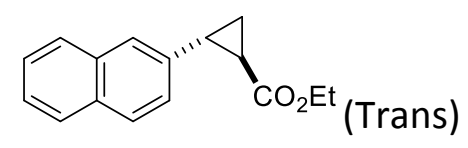

28: ${ }^{1} \mathrm{H}$ NMR $\left(300 \mathrm{MHz}, \mathrm{CDCl}_{3}\right) \delta 7.78(\mathrm{t}, J=8.8 \mathrm{~Hz}, 2 \mathrm{H}), 7.58(\mathrm{~s}, 1 \mathrm{H}), 7.45(\mathrm{pd}, J=6.8,3.4 \mathrm{~Hz}$, 2H), $7.21(\mathrm{dd}, J=8.5,1.7 \mathrm{~Hz}, 1 \mathrm{H}), 4.20(\mathrm{q}, J=7.2 \mathrm{~Hz}, 2 \mathrm{H}), 2.76-2.59(\mathrm{~m}, 1 \mathrm{H}), 2.08-1.96(\mathrm{~m}$, $1 \mathrm{H}), 1.68(\mathrm{dt}, J=9.7,4.9 \mathrm{~Hz}, 1 \mathrm{H}), 1.43(\mathrm{ddd}, J=8.4,6.5,4.6 \mathrm{~Hz}, 1 \mathrm{H}), 1.30(\mathrm{t}, J=7.1 \mathrm{~Hz}, 3 \mathrm{H})$; ${ }^{13} \mathrm{C}$ NMR $\left(75 \mathrm{MHz} \mathrm{CDCl}_{3}\right) \delta 173.38,137.54,133.38,132.30,128.17,127.62,127.40,126.26$, $125.49,124.79,124.58,60.75,26.42,24.14,17.02,14.29$.
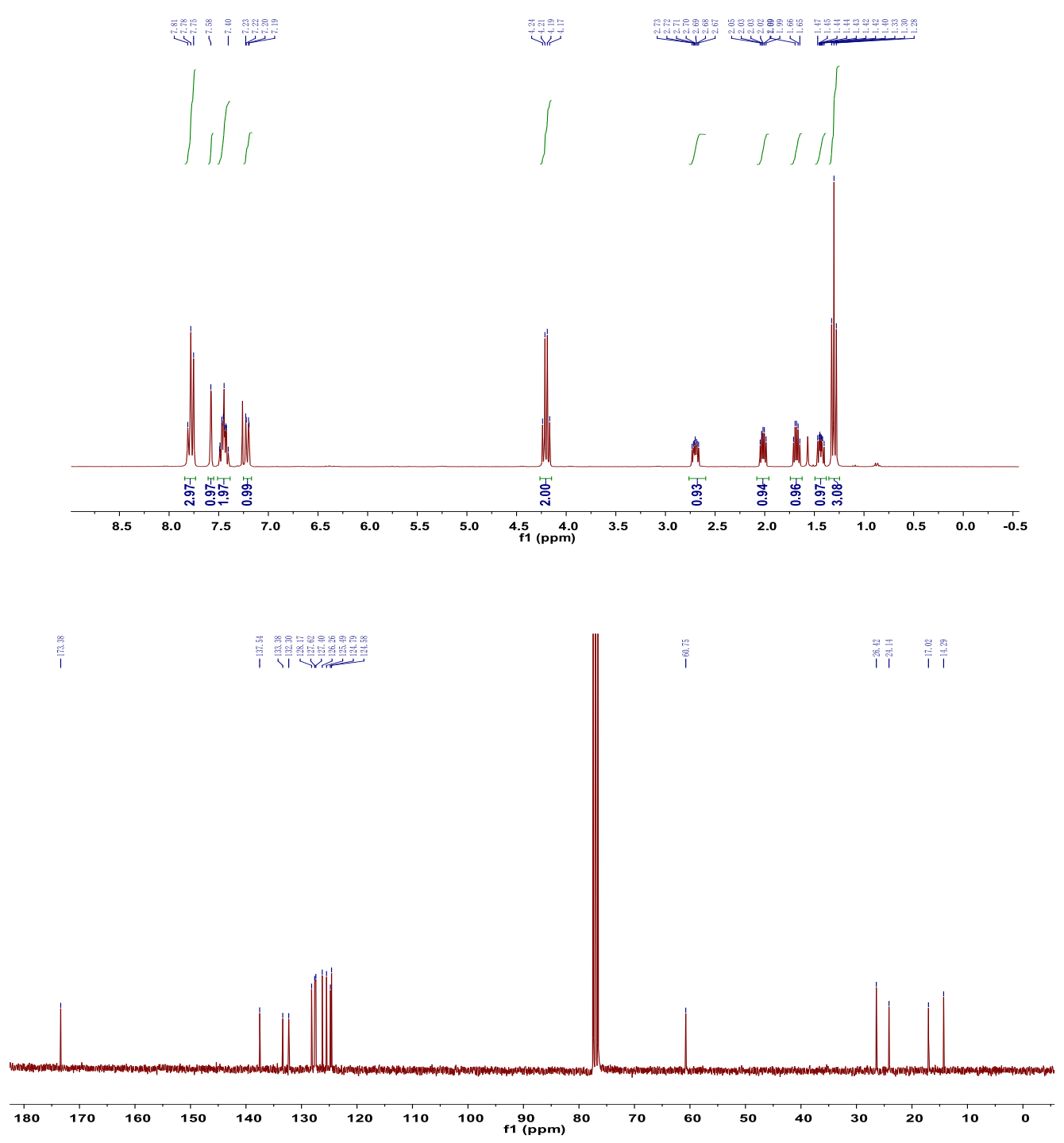


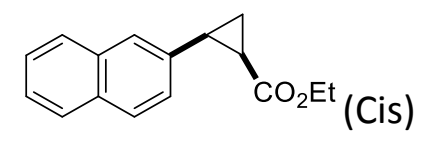

28: ${ }^{1}$ H NMR $\left(400 \mathrm{MHz}, \mathrm{CDCl}_{3}\right) \delta 7.85-7.63(\mathrm{~m}, 4 \mathrm{H}), 7.49-7.32(\mathrm{~m}, 3 \mathrm{H}), 3.84(\mathrm{q}, J=7.1 \mathrm{~Hz}$, $2 \mathrm{H}), 2.73(\mathrm{dd}, J=17.0,8.4 \mathrm{~Hz}, 1 \mathrm{H}), 2.16(\mathrm{ddd}, J=9.3,7.8,5.6 \mathrm{~Hz}, 1 \mathrm{H}), 1.93-1.76(\mathrm{~m}, 1 \mathrm{H})$, $1.42(\mathrm{ddd}, J=8.6,7.8,5.1 \mathrm{~Hz}, 1 \mathrm{H}), 0.92(\mathrm{t}, J=7.1 \mathrm{~Hz}, 3 \mathrm{H}) ;{ }^{13} \mathrm{C}$ NMR $\left(101 \mathrm{MHz}, \mathrm{CDCl}_{3}\right) \delta 170.92$, 134.12, 133.63, 133.22, 132.43, 127.91, 127.65, 127.57, 127.37, 125.86, 125.44, 60.10, 25.68, $22.01,14.02,11.35$.

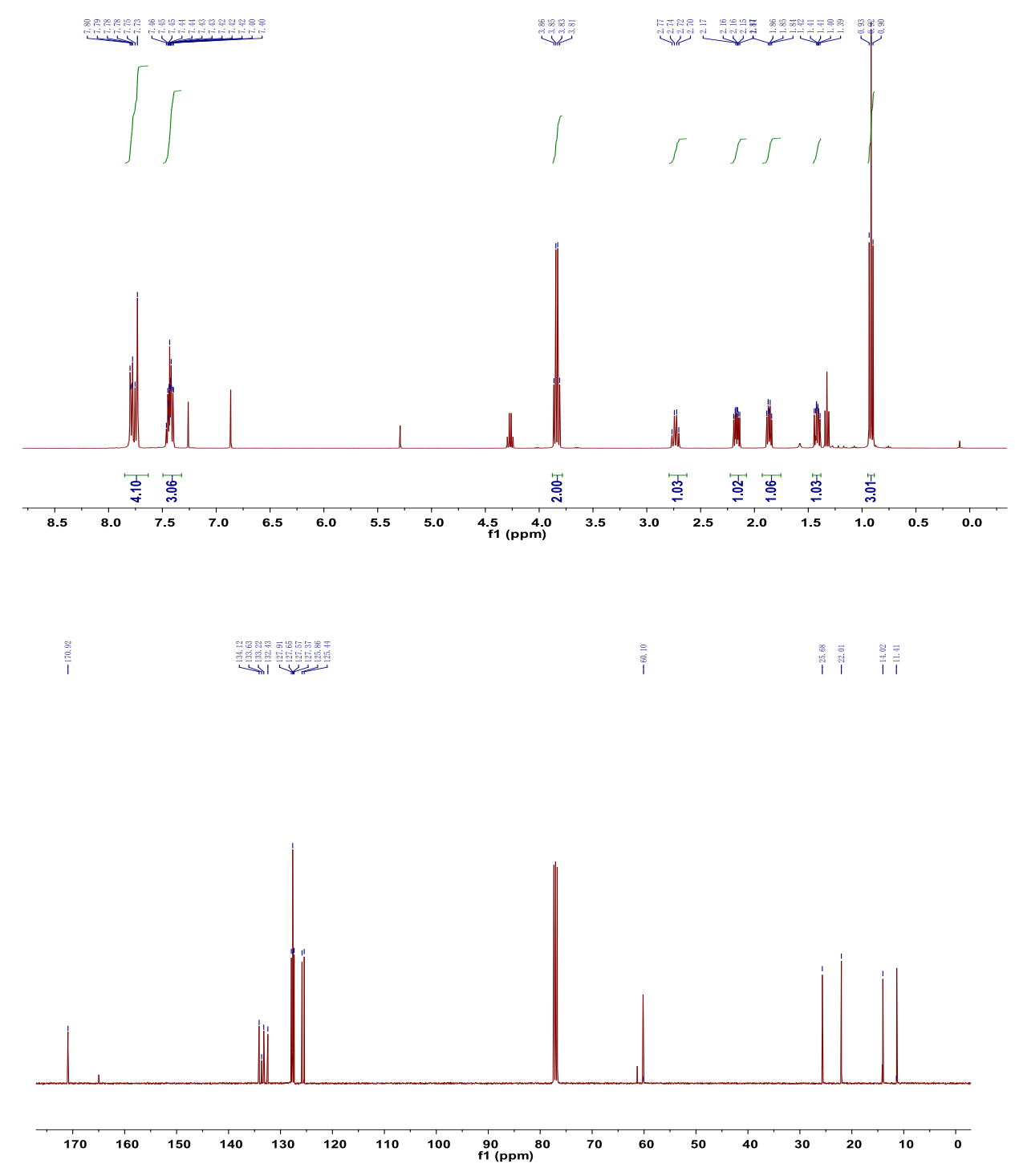




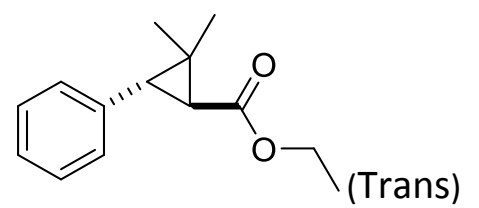

29: ${ }^{1} \mathrm{H}$ NMR $\left(400 \mathrm{MHz}, \mathrm{CDCl}_{3}\right) \delta 7.29(\mathrm{tt}, J=8.1,1.5 \mathrm{~Hz}, 1 \mathrm{H}), 7.24-7.14(\mathrm{~m}, 1 \mathrm{H}), 4.19(\mathrm{qd}, J=$ 7.1, 2.4 Hz, 1H), $2.70(\mathrm{~d}, J=5.9 \mathrm{~Hz}, \mathrm{OH}), 1.96(\mathrm{~d}, J=5.9 \mathrm{~Hz}, \mathrm{OH}), 1.39(\mathrm{~s}, 1 \mathrm{H}), 1.31(\mathrm{t}, J=7.1 \mathrm{~Hz}$, 1H), 0.93 (s, 3H); ${ }^{13} \mathrm{C}$ NMR (101 MHz, CDCl3) $\delta$ 172.28, 137.44, 128.75, 128.12 126.33, 60.42, $37.41,31.63,29.22,21.95,20.67,14.41$.
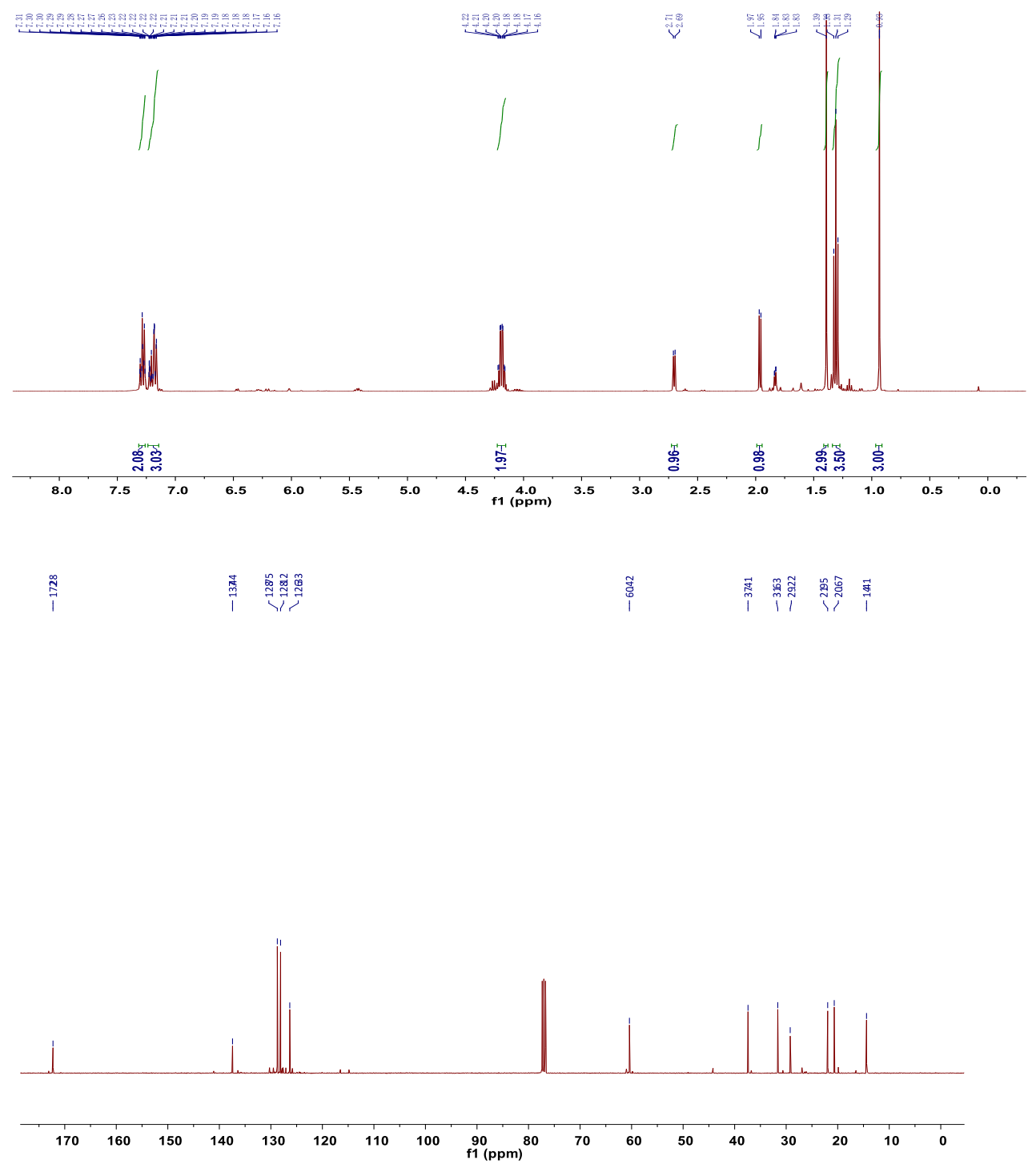


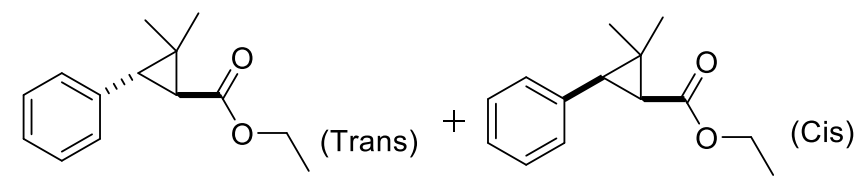

29: ${ }^{1} \mathrm{H}$ NMR $\left(400 \mathrm{MHz}, \mathrm{CDCl}_{3}\right) \delta 7.33-7.10$ (m, trans and cis $\left.\mathrm{H}\right), 4.19$ (qd, trans $\left.\mathrm{H}\right), 4.05$ (dtd, cis $\mathrm{H}), 2.70(\mathrm{~d}$, trans $\mathrm{H}), 2.45(\mathrm{~d}$, cis $\mathrm{H}), 1.96(\mathrm{~d}$, trans $\mathrm{H}), 1.86(\mathrm{~d}$, cis $\mathrm{H}), 1.55(\mathrm{~s}$, cis $\mathrm{H}), 1.39(\mathrm{~s}$, trans $\mathrm{H}), 1.35(\mathrm{~s}, \mathrm{cis} \mathrm{H}), 1.31(\mathrm{t}$, trans $\mathrm{H}), 1.19(\mathrm{t}$, cis $\mathrm{H}), 0.93(\mathrm{~s}$, trans $\mathrm{H})$.

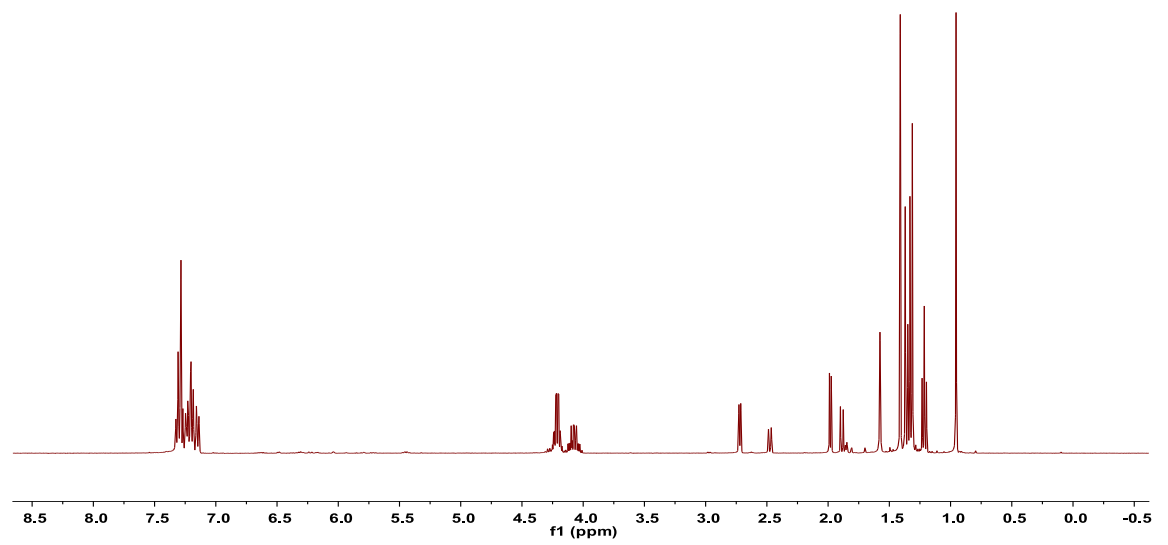




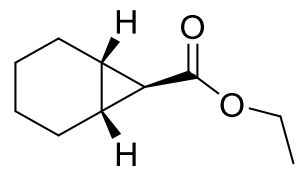

(Trans)

30: ${ }^{1} \mathrm{H}$ NMR $(400 \mathrm{MHz}, \mathrm{CDCl} 3) \delta 4.11$ (q, J = $\left.7.1 \mathrm{~Hz}, 2 \mathrm{H}\right), 1.91$ (dddd, J = 9.9, 7.4, 4.0, $2.0 \mathrm{~Hz}$, 2H), $1.77-1.66(m, 2 H), 1.60(d d d, J=5.5,3.9,1.0 \mathrm{~Hz}, 2 \mathrm{H}), 1.39(\mathrm{t}, \mathrm{J}=4.3 \mathrm{~Hz}, 1 \mathrm{H}), 1.35-$ $1.24(\mathrm{~m}, 5 \mathrm{H}), 1.24-1.12(\mathrm{~m}, 2 \mathrm{H}) ;{ }^{13} \mathrm{C}$ NMR $(101 \mathrm{MHz}, \mathrm{CDCl} 3) \delta 174.84,60.14,25.67,22.72$, $22.09,20.94,14.29$.
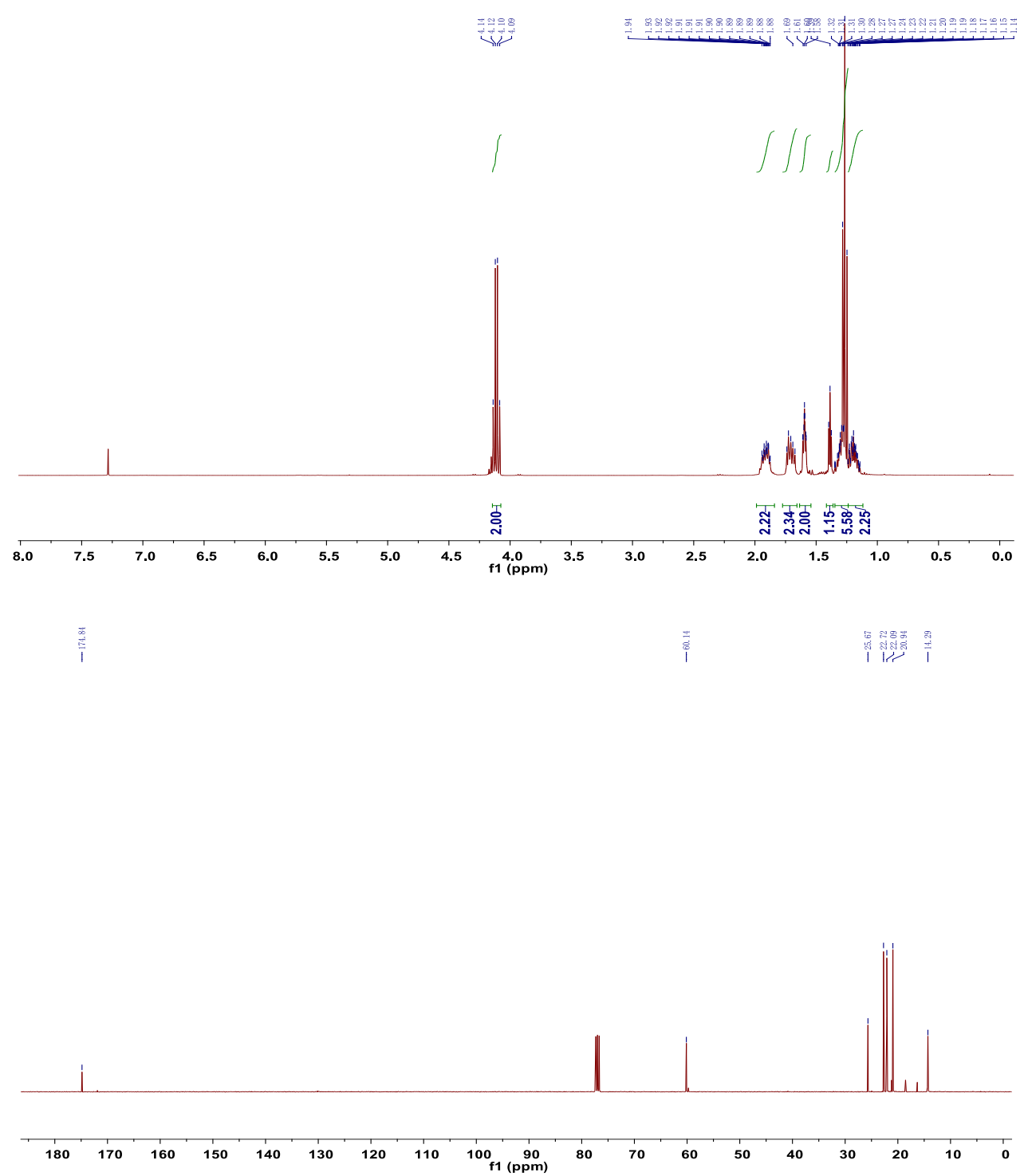


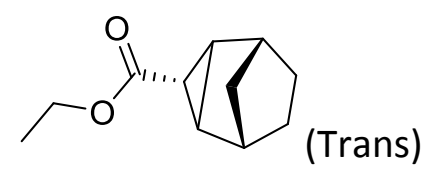

31: ${ }^{1} \mathrm{H}$ NMR $\left(400 \mathrm{MHz}, \mathrm{CDCl}_{3}\right) \delta 4.08(\mathrm{q}, J=7.1 \mathrm{~Hz}, 2 \mathrm{H}), 2.35(\mathrm{~s}, 2 \mathrm{H}), 1.52(\mathrm{t}, J=2.5 \mathrm{~Hz}, 1 \mathrm{H})$, $1.49-1.41(\mathrm{~m}, 2 \mathrm{H}), 1.37-1.27(\mathrm{~m}, 4 \mathrm{H}), 1.23(\mathrm{t}, J=7.1 \mathrm{~Hz}, 3 \mathrm{H}), 0.94-0.85(\mathrm{~m}, 1 \mathrm{H}), 0.67(\mathrm{~d}, J$ $=10.8 \mathrm{~Hz}, 1 \mathrm{H}) ;{ }^{13} \mathrm{C}$ NMR $\left(101 \mathrm{MHz}, \mathrm{CDCl}_{3}\right) \delta 174.21,60.18,35.80,28.68,28.55,25.90,16.30$, 14.27 .
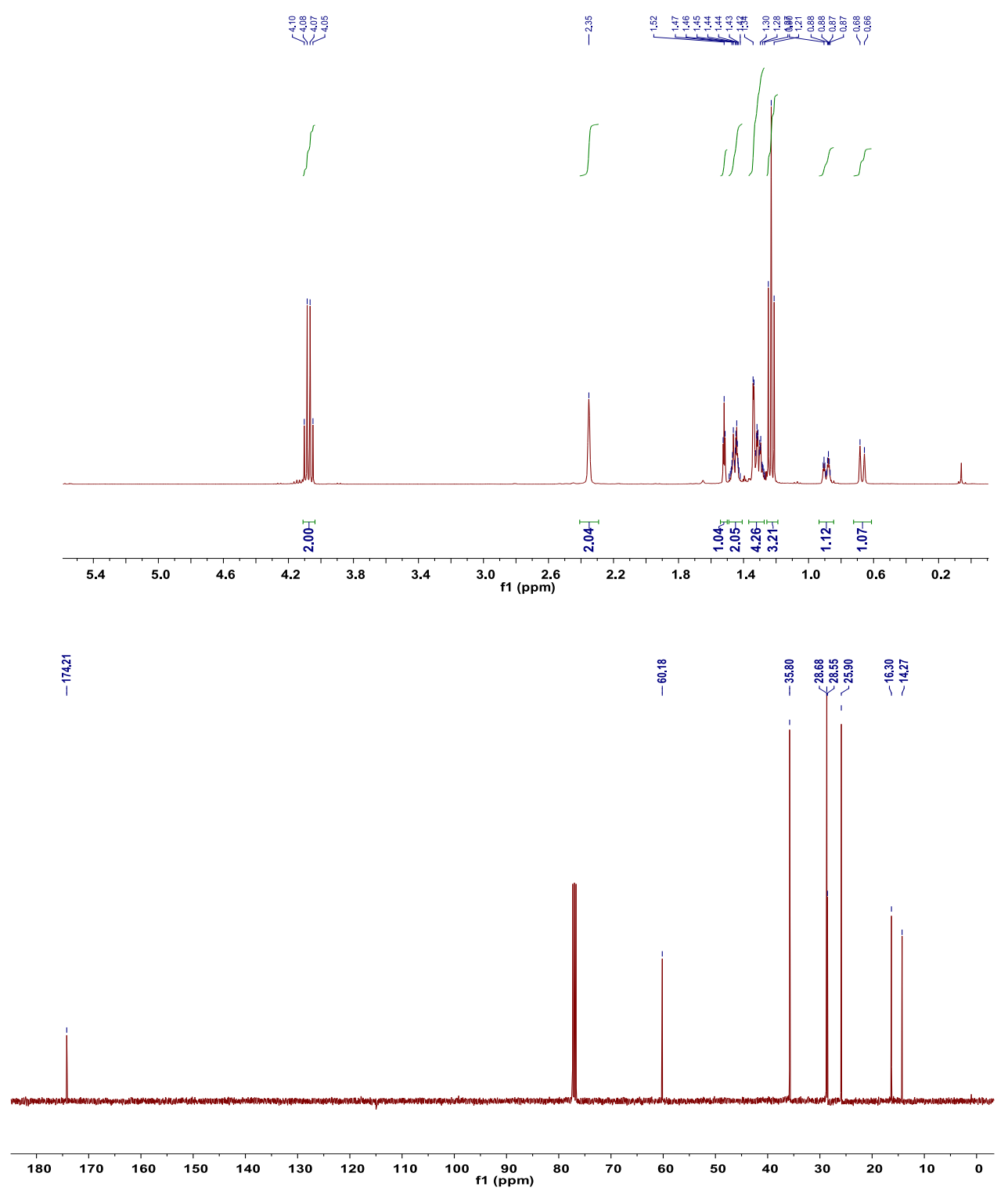


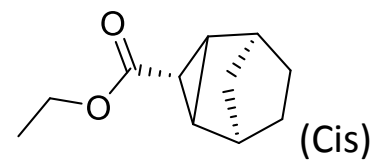

31: ${ }^{1} \mathrm{H}$ NMR $\left(400 \mathrm{MHz}, \mathrm{CDCl}_{3}\right) \delta 4.13(\mathrm{q}, J=7.1 \mathrm{~Hz}, 2 \mathrm{H}), 2.50(\mathrm{~s}, 2 \mathrm{H}), 1.54-1.43(\mathrm{~m}, 2 \mathrm{H}), 1.32$ - $1.20(\mathrm{~m}, 6 \mathrm{H}), 1.10(\mathrm{~d}, J=7.5 \mathrm{~Hz}, 2 \mathrm{H}), 0.74(\mathrm{dd}, J=3.5,1.7 \mathrm{~Hz}, 2 \mathrm{H}) ;{ }^{13} \mathrm{C}$ NMR $(101 \mathrm{MHz}$, $\left.\mathrm{CDCl}_{3}\right) \delta 172.39,60.54,36.04,29.46,29.41,21.71,20.75,14.06$.

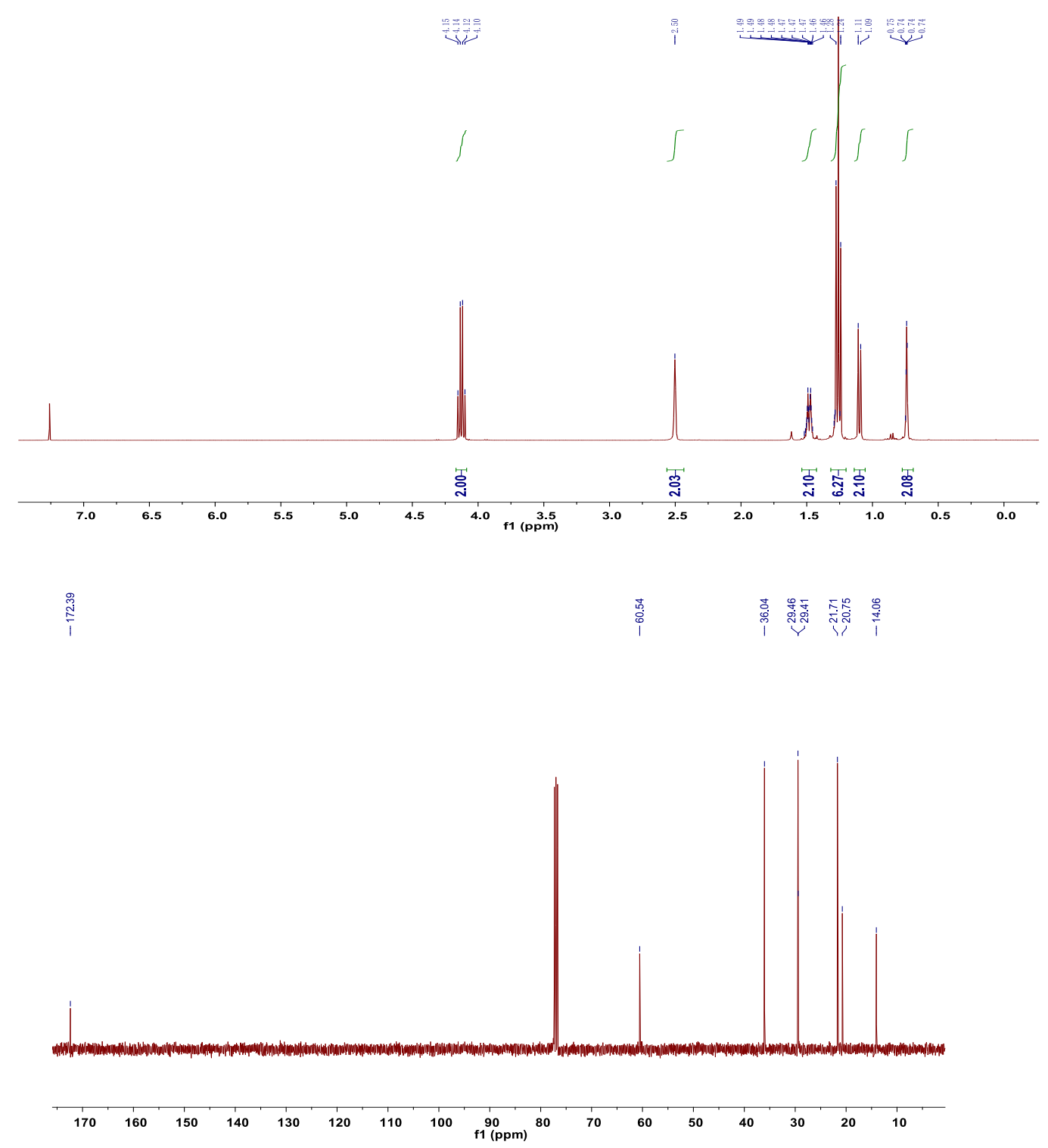




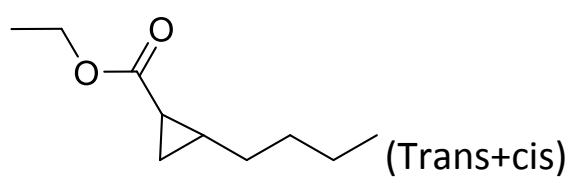

32: ${ }^{1} \mathrm{H}$ NMR (400 MHz, $\mathrm{CDCl}_{3}$, trans and cis-isomers): $\delta$ 4.13-4.09 (q, J = 7.2 Hz, cis-2H), 4.13-4.19 $(q, J=7.1 \mathrm{~Hz}$, trans-2H), 1.70-1.10 $(\mathrm{m}, 24 \mathrm{H}), 1.03-0.93(\mathrm{~m}, \mathrm{cis}-1 \mathrm{H}), 0.89(\mathrm{t}, \mathrm{J}=7.0$ $\mathrm{Hz}$, trans-3H), $0.88\left(\mathrm{t}, \mathrm{J}=6.9 \mathrm{~Hz}\right.$, cis-3H), $0.68\left(\mathrm{ddd}, \mathrm{J}=4.1,5.4,7.6 \mathrm{~Hz}\right.$, trans-1H); ${ }^{13} \mathrm{C} \mathbf{N M R}$ $\left(101 \mathrm{MHz}, \mathrm{CDCl}_{3}\right) \delta 174.56,173.02,60.22,60.14,32.72,31.84,31.24,26.69,22.85,22.35$, $22.33,21.88,20.20,18.21,15.46,14.34,14.25,14.04,13.98,13.29$.
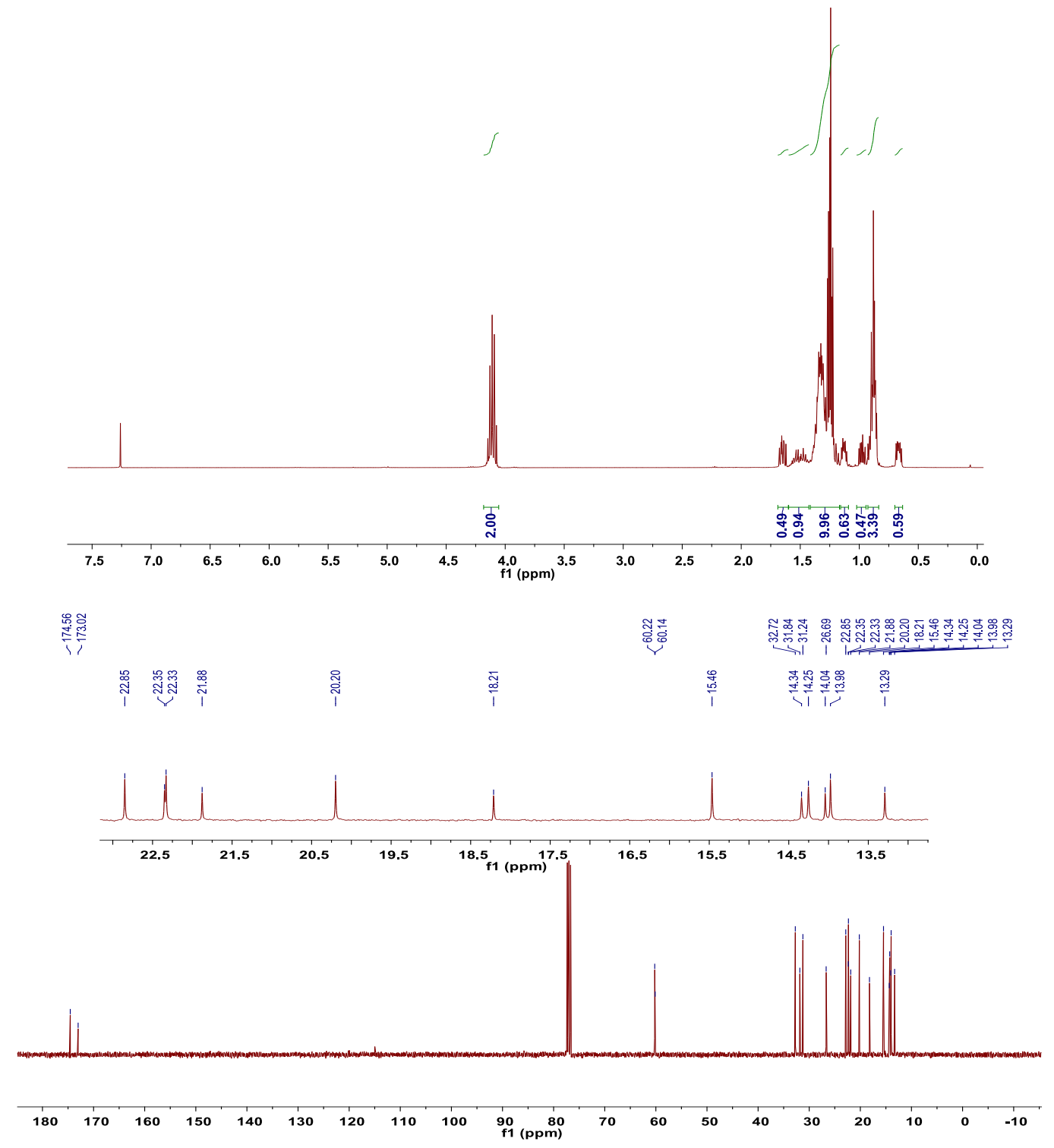


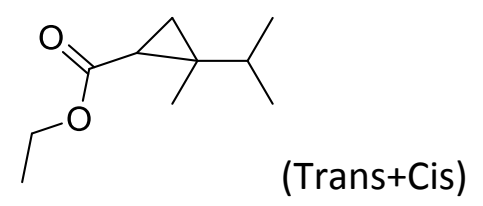

33: ${ }^{1} \mathrm{H}$ NMR $\left(400 \mathrm{MHz}, \mathrm{CDCl}_{3}\right) \delta 4.19-4.04(\mathrm{~m}, 4 \mathrm{H}), 1.73(\mathrm{dt}, J=13.8,6.9 \mathrm{~Hz}, 1 \mathrm{H}), 1.46$ (ddd, $J=20.3,7.9,5.5 \mathrm{~Hz}, 2 \mathrm{H}), 1.25(\mathrm{td}, J=7.1,1.0 \mathrm{~Hz}, 6 \mathrm{H}), 1.11-0.92(\mathrm{~m}, 18 \mathrm{H}), 0.85-0.78(\mathrm{~m}$, 5H); ${ }^{13} \mathrm{C}$ NMR $\left(101 \mathrm{MHz}, \mathrm{CDCl}_{3}\right) \delta 172.73,172.68,60.16,60.07,37.99,32.02,31.62,28.85$, $27.84,26.82,22.04,21.35,19.52,19.20,19.09,19.00,18.29,14.38,14.34,11.09$.

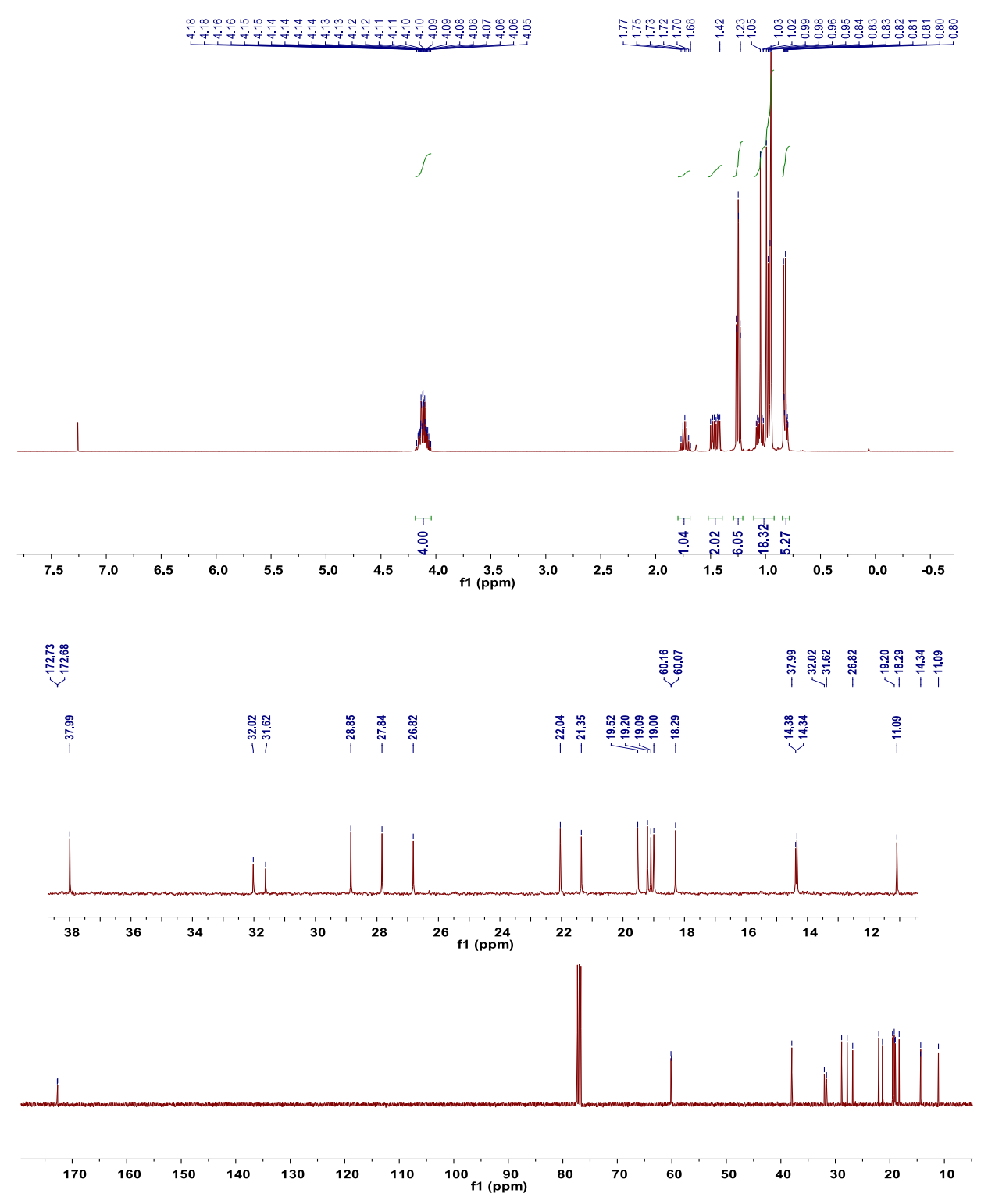




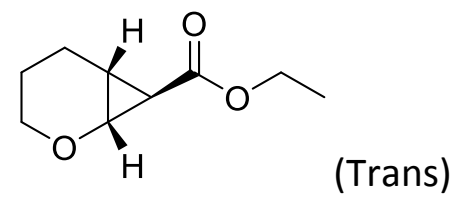

34: ${ }^{1} \mathrm{H}$ NMR $\left(400 \mathrm{MHz}, \mathrm{CDCl}_{3}\right) \delta 4.19-4.04(\mathrm{~m}, 2 \mathrm{H}), 3.90(\mathrm{dd}, \mathrm{J}=5.8,3.4 \mathrm{~Hz}, 1 \mathrm{H}), 3.65-3.53$ $(\mathrm{m}, 1 \mathrm{H}), 3.36(\mathrm{td}, \mathrm{J}=11.2,2.2 \mathrm{~Hz}, 1 \mathrm{H}), 2.09-1.88(\mathrm{~m}, 2 \mathrm{H}), 1.80-1.65(\mathrm{~m}, 2 \mathrm{H}), 1.58-1.38$ $(\mathrm{m}, 2 \mathrm{H}), 1.24(\mathrm{t}, \mathrm{J}=7.1 \mathrm{~Hz}, 3 \mathrm{H}) ;{ }^{13} \mathrm{C}$ NMR $\left(101 \mathrm{MHz}, \mathrm{CDCl}_{3}\right) \delta 172.44,64.47,60.34,59.77$, $26.46,21.99,21.90,18.89,14.27$

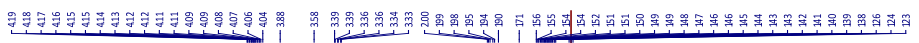
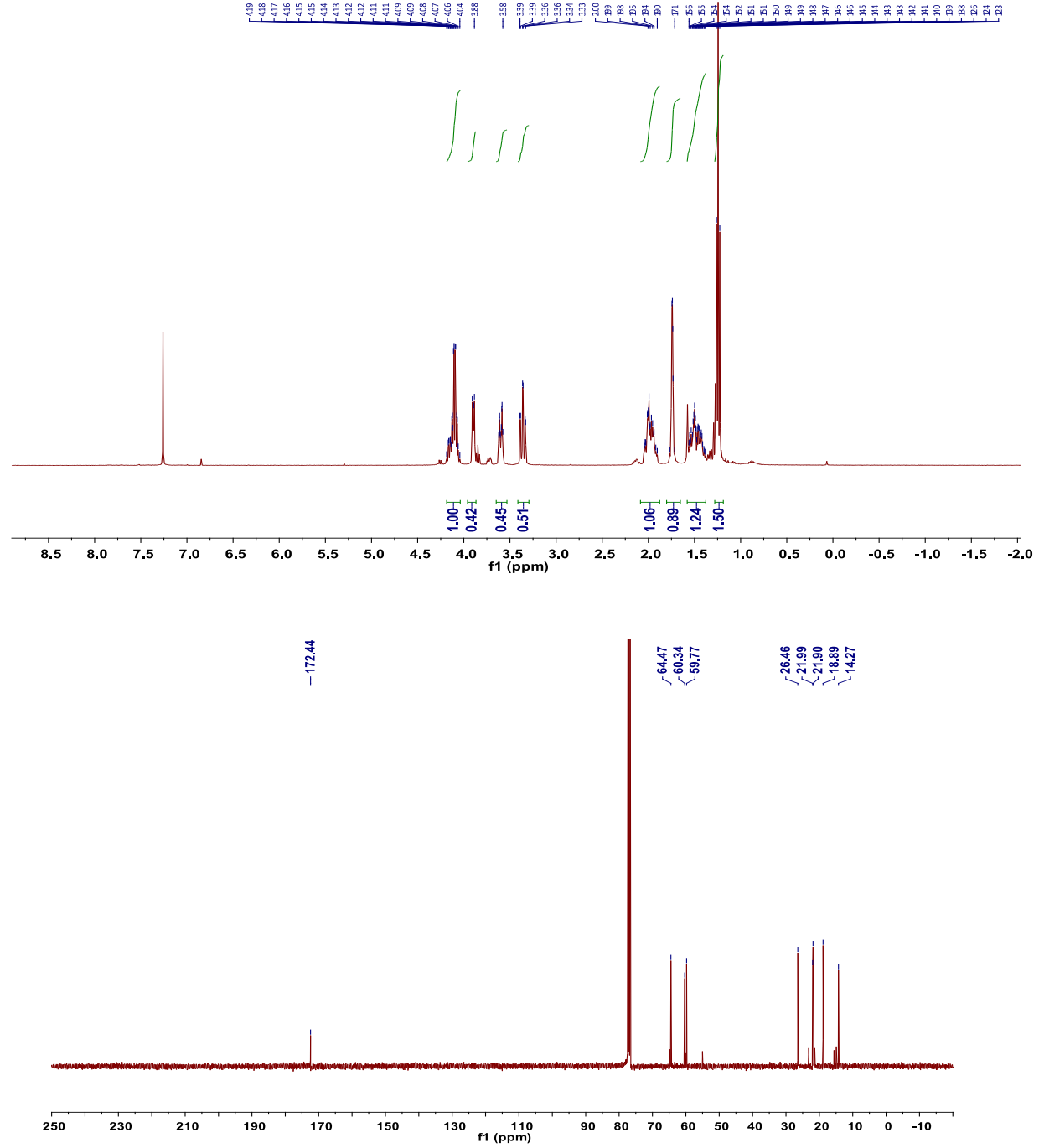


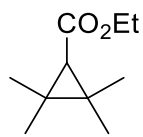

35: ${ }^{1} \mathrm{H}$ NMR $\left(400 \mathrm{MHz}, \mathrm{CDCl}_{3}\right) \delta 4.07(\mathrm{q}, \mathrm{J}=7.1 \mathrm{~Hz}, 2 \mathrm{H}), 1.27-1.22(\mathrm{~m}, 9 \mathrm{H}), 1.17(\mathrm{~s}, 6 \mathrm{H}), 1.16$ (s, 1H); ${ }^{13} \mathrm{C}$ NMR $(101 \mathrm{MHz}, \mathrm{CDCl} 3) \delta 172.14,59.49,35.80,29.84,23.52,16.54,14.37$.

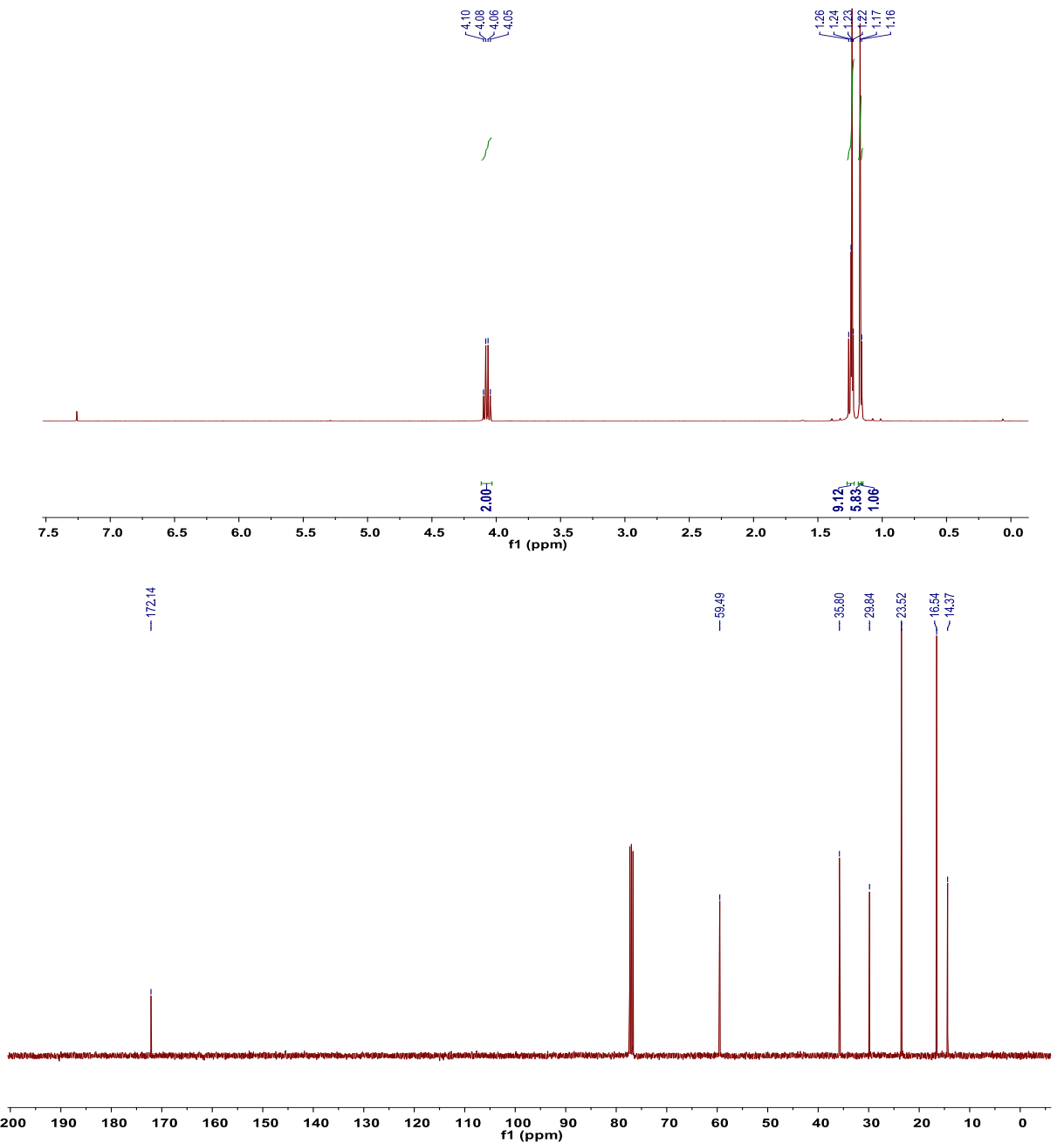




\section{DFT Calculations}

All theoretical calculations were based on density functional theory (DFT) and have been performed with the ORCA program package. ${ }^{6}$ Geometry optimization were performed with the GGA functional BP86 ${ }^{7}$ using the TZVP ${ }^{8}$ basis set for all atoms and by taking advantage of the resolution of the identity (RI) approximation in the Split-RI-J variant ${ }^{9}$ with the appropriate Coulomb fitting sets. ${ }^{10}$ Increased integration grids (Grid4 in ORCA convention) and tight SCF convergence criteria were used. Complexes 1, 36, 37 and $\mathbf{3}$ consist of two to three magnetically interacting centres and can be best described by the Broken Symmetry (BS) approach, ${ }^{11}$ as already demonstrated in studies of related systems. ${ }^{12}$ Single-point BS-DFT calculations were performed with the hybrid functional B3LYP ${ }^{13}$ and the alternative spin configurations for the BS calculations were generated with the "FlipSpin" feature of ORCA. For the description of the systems we used the isotropic Heisenberg-Dirac-Van Vleck (HDvV) exchange Hamiltonian ${ }^{14} H=-2 \sum_{i>j} J_{i j} S_{i} S_{j}$ where $J_{i j}$ is the exchange coupling between pairwise number $i$ and $j$ while $S i$ is the spin operator of the $i$ th metal center. The possible pairwise exchange couplings in these systems were determined within the BS-DFT framework and diagonalization of the HDvV Hamiltonian which provides the magnetic sublevel spectrum of the species was performed by employing the orca_eca utility of ORCA. The relative energies were also obtained from single-point calculations using the B3LYP functional together with the TZV/P basis set. They were computed from the gas-phase

${ }^{6}$ F. Neese, Wiley Interdiscip. Rev. Comput. Mol. Sci. 2012, 2, 73-78.

7 a) J. P. Perdew, Phys. Rev. B 1986, 33, 8822-8824; b) J. P. Perdew, Phys. Rev. B 1986, 34, 7406-7406; c) A. D. Becke, Phys. Rev. A 1988, 38, 3098-3100.

${ }^{8}$ A. Schäfer, C. Huber, R. J. Ahlrichs, Chem. Phys. 1994, 100, 5829-5835.

9 F. Neese, J. Comput. Chem. 2003, 24, 1740-1747.

10 F. Weigend, PhysChem ChemPhys 2006, 8, 1057-1065.

11 a) L. Noodleman, J. Chem. Phys. 1981, 74, 5737-5743; b) L. Noodleman, E. R. Davidson, Chem. Phys. 1986, 109, 131-143.

12 a) A. D. Pantazis, M. Orio, T. Petrenko, S. Zein, E. Bill, W. Lubitz, J. Messinger, F. Neese, Chem. Eur. J. 2009, 15, 5108-5123. b) C. Baffert, M. Orio, D. A. Pantazis, C. Duboc, A. G. Blackman, G. Blondin, F. Neese, A. Deronzier, M.-N. Collomb, Inorg. Chem., 2009, 48, 10281-10288. c) A. Kochem, B. Faure, S. Bertaina, E. Rivière, M. Giorgi, M. Réglier, M. Orio, A. J. Simaan, Eur J. Inorg. Chem., 2018, 47, 50395046.

${ }^{13}$ A. D. Becke, J. Chem. Phys. 1993, 98, 5648-5652; b) C. T.Lee, W. T. Yang, R. G. Parr, Phys. Rev. B 1988, 37, 785-789.

14 a) P. A. M. Dirac, Proc. Roy. Soc. 1929, A123, 714; b) W. Heisenberg, Z. Physik 1926, 38, 411-426; c) W. Heisenberg, Z. Physik 1928, 49, 619-636; d) J. H. Vleck, In The Theory of Electronic and Magnetic Susceptibilies, Oxford University: London: 1932; p 384. 
optimized structures as a sum of electronic energy and thermal corrections to free energy. Zero point vibrational energy (ZPVE) corrections ${ }^{15}$ were evaluated from the calculated harmonic frequencies and are included in the total energies. The counterpoise (CP) procedure was used to correct the total energy for the basis set superposition error (BSSE). ${ }^{16}$ Molecular orbitals and spin-density plots were generated using the orca plot utility program and were visualized with the Chemcraft program. ${ }^{17}$

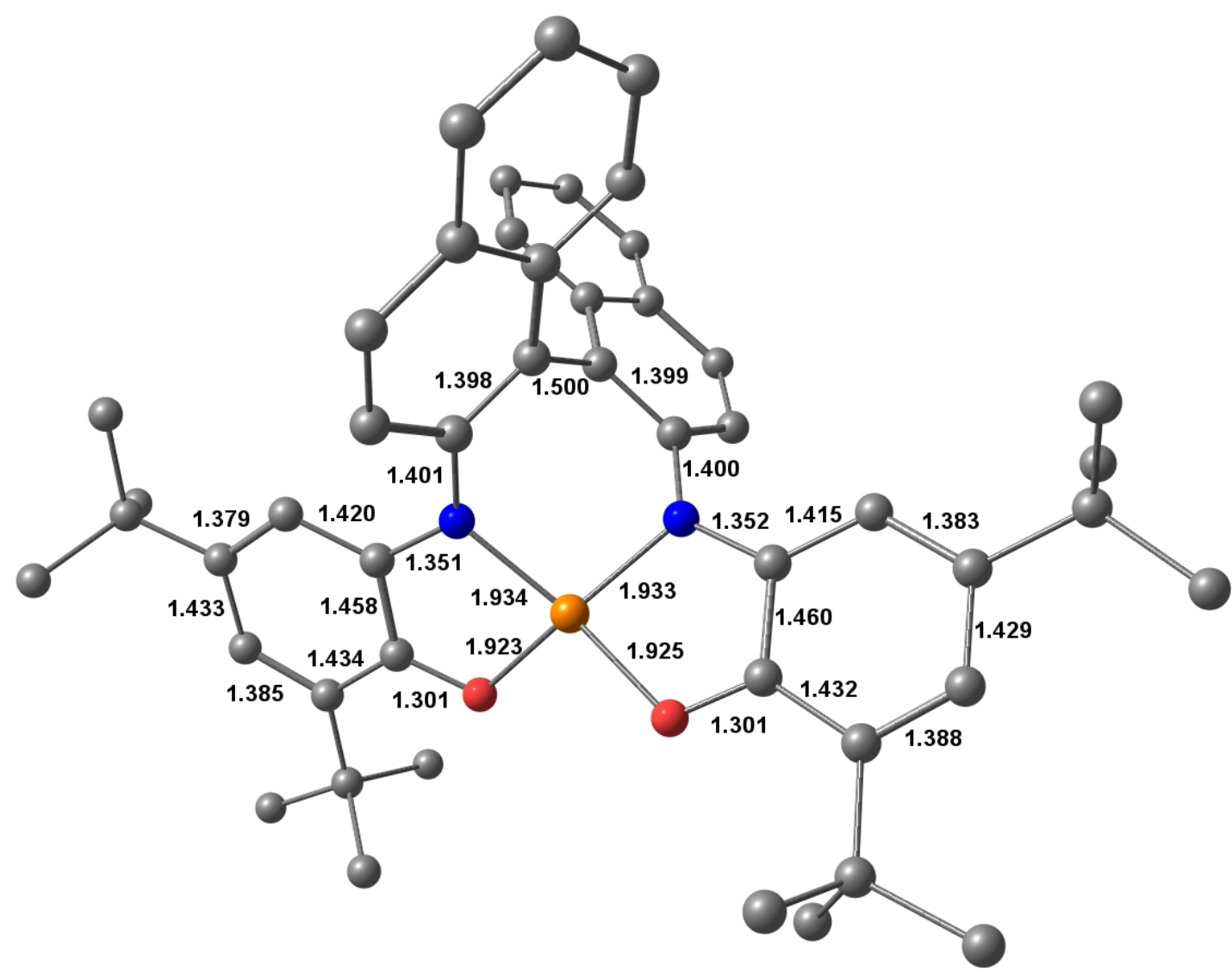

Figure SI-27: DFT-optimized structure of $\mathbf{3}$ and selected metrical parameters. Color scheme: Cu brown, $\mathrm{O}$ red, $\mathrm{N}$ blue and $\mathrm{C}$ grey. Protons were omitted for clarity.

${ }^{15}$ R. Krishnan, J. S. Binkley, R. Seeger, J. A. Pople, J Chem. Phys. 1980, 72, 650-654.

16 a) S. F. Boys, F. Bernardi, Mol. Phys. 1970, 19, 553-566; b) S. Simon, M. Duran, J. J. Dannenberg, J. Chem. Phys. 1996, 105, 11024-11031.

17 Chemcraft, http://chemcraftprog.com. 


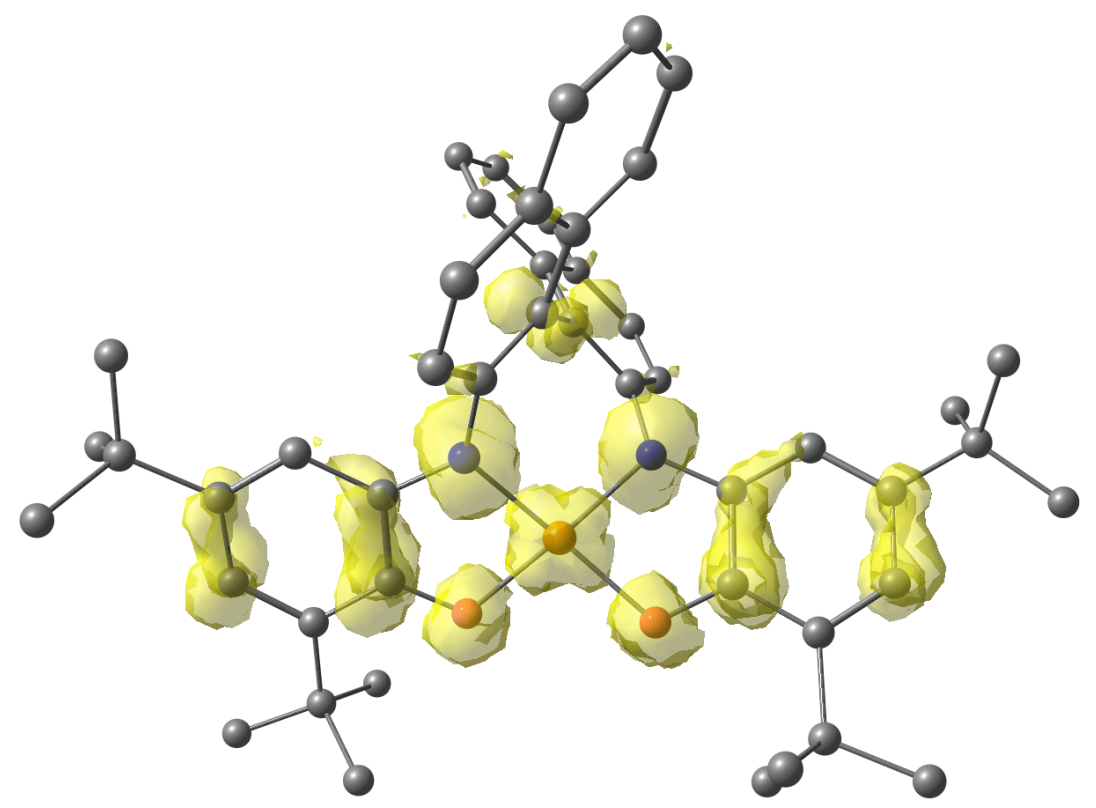

Figure SI-28: Spin density plot for the HS state of 3.
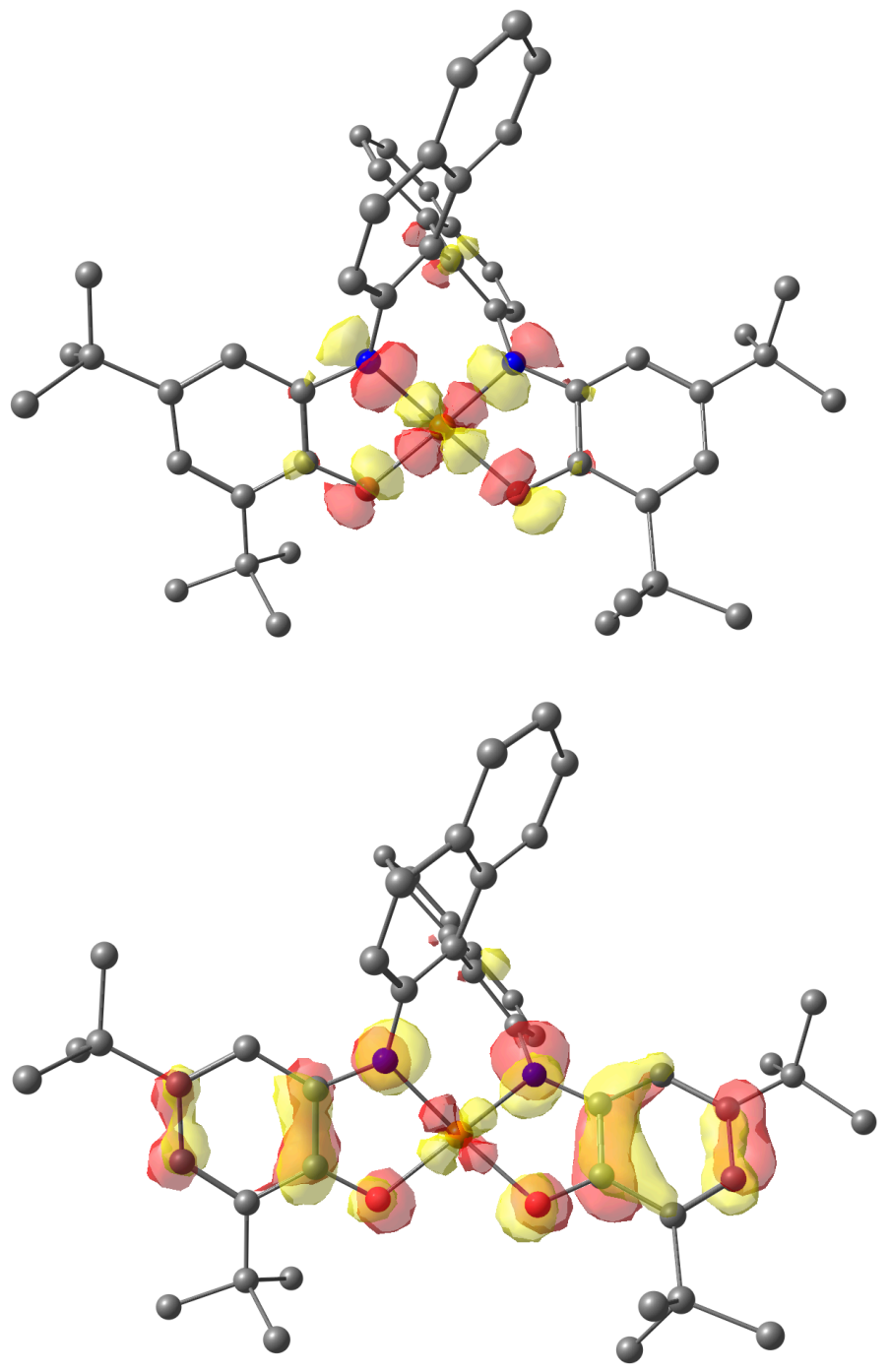


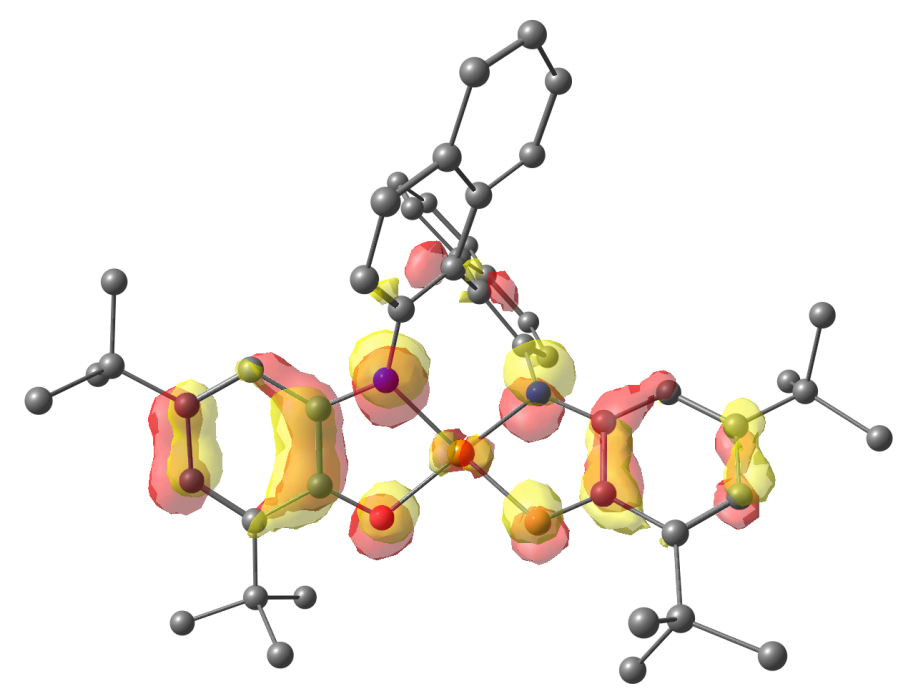

Figure SI-29: Localized SOMOs of the high-spin state of $\mathbf{3 .}$

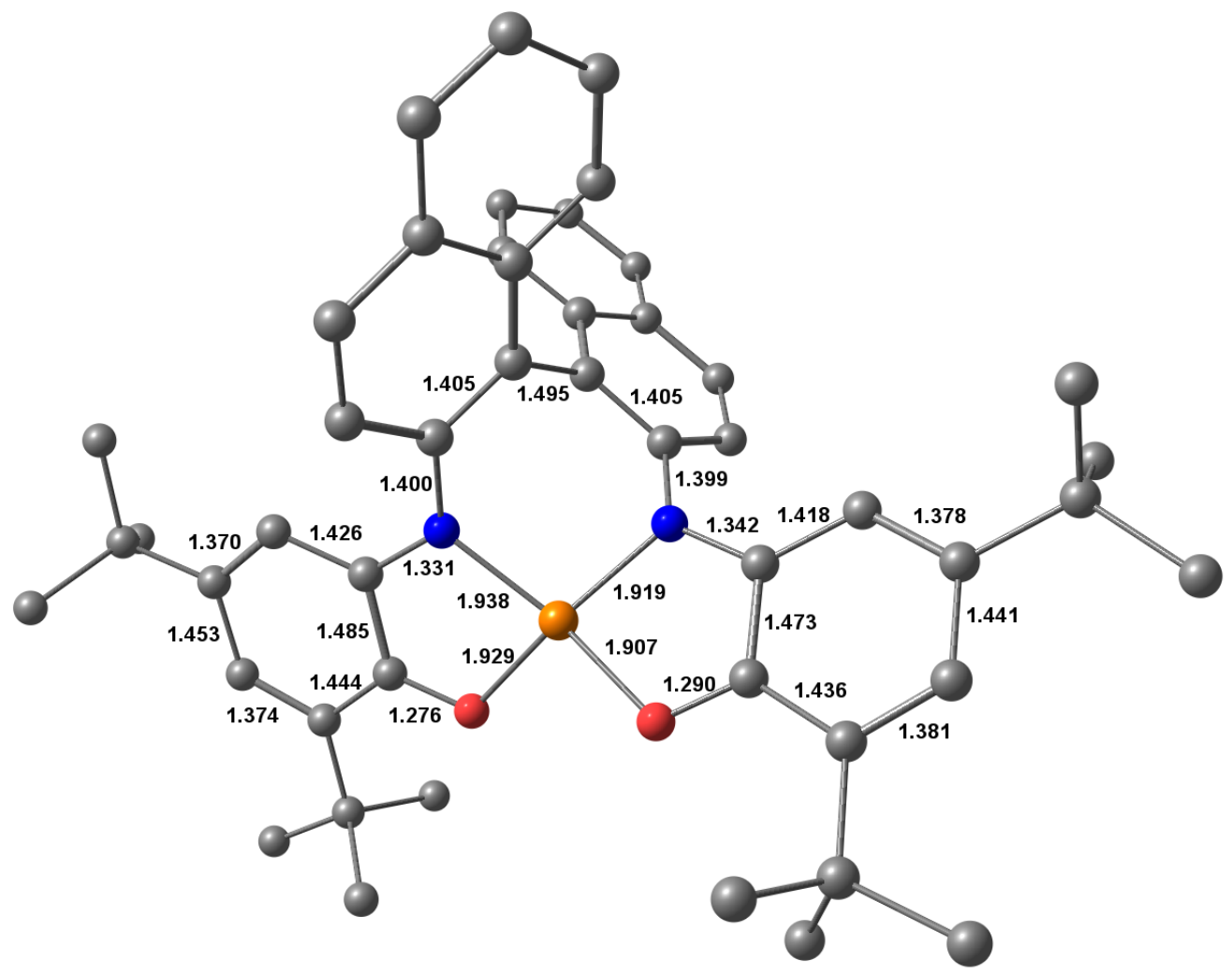

Figure SI-30: DFT-optimized structure of 1 and selected metrical parameters. Color scheme: Cu brown, $\mathrm{O}$ red, $\mathrm{N}$ blue and $\mathrm{C}$ grey. Protons were omitted for clarity. 

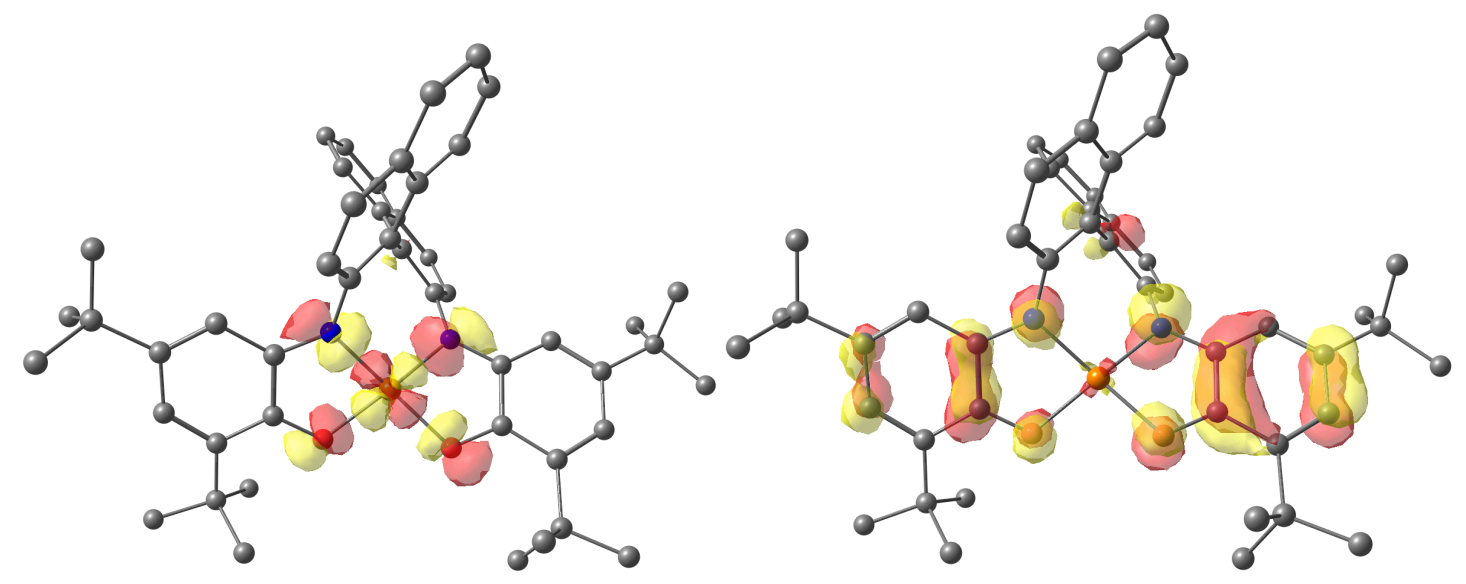

Figure SI-31: Localized SOMO of the high-spin state of 1.

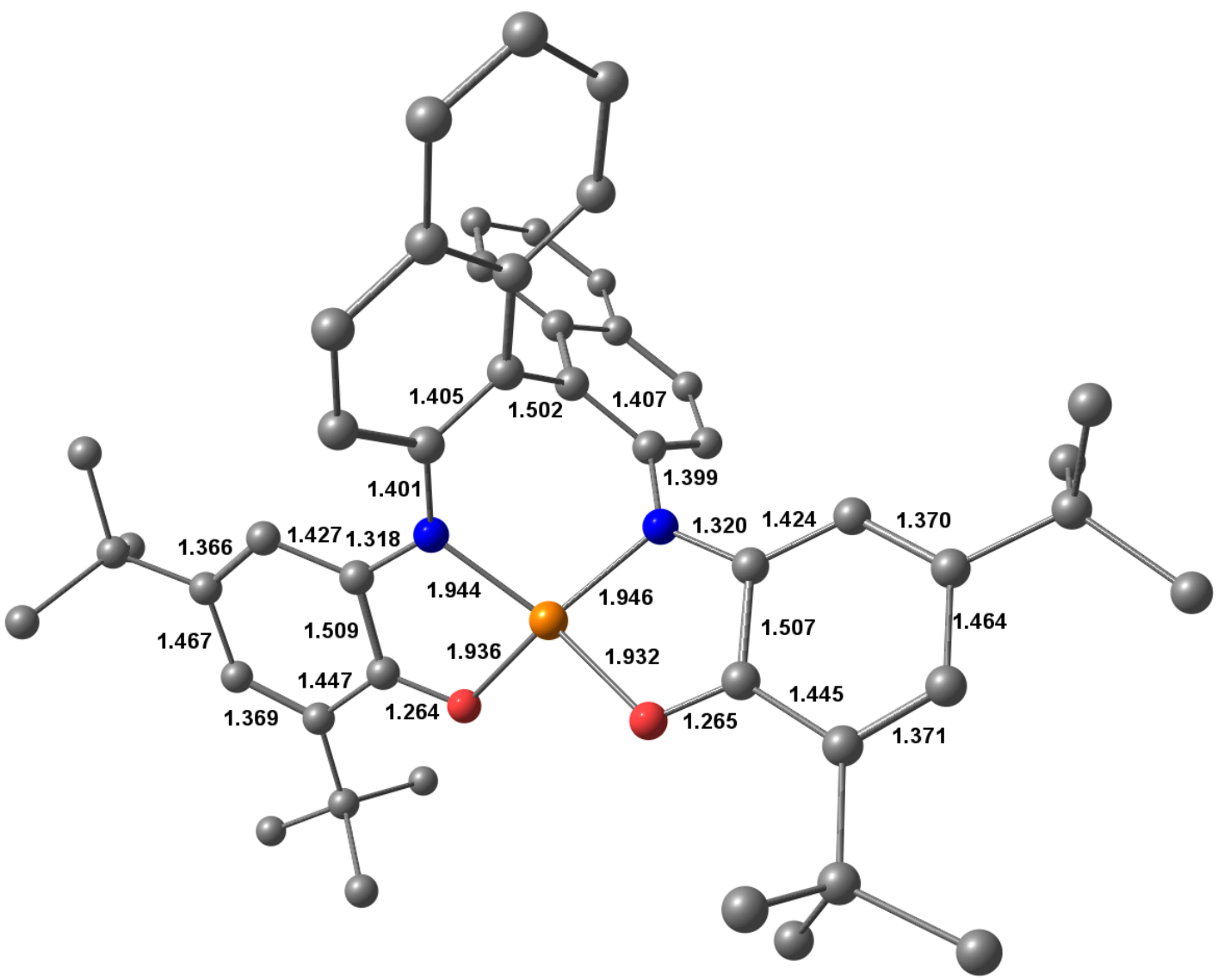

Figure SI-32: DFT-optimized structure of 5 and selected metrical parameters. Color scheme: Cu brown, $\mathrm{O}$ red, $\mathrm{N}$ blue and $\mathrm{C}$ grey. Protons were omitted for clarity. 


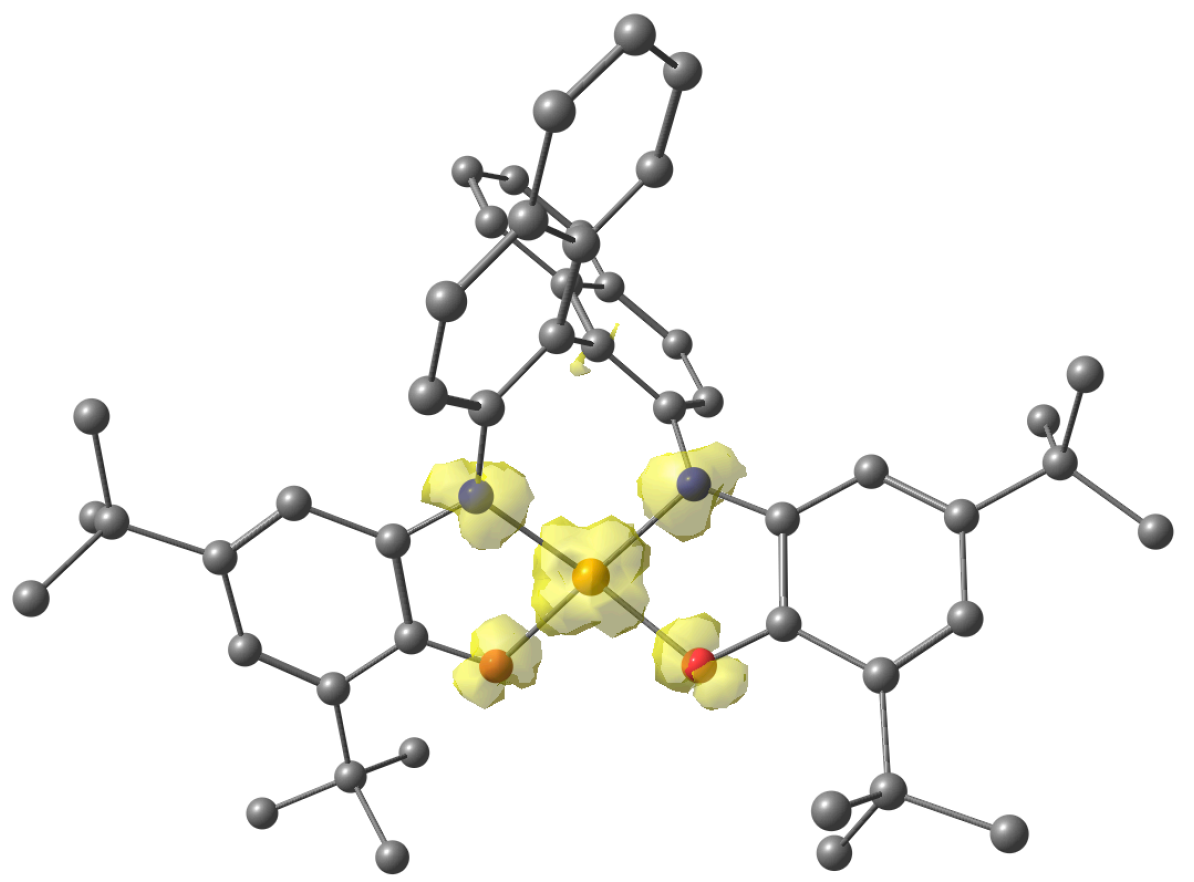

Figure SI-33: Spin density plot for $\mathbf{5}$.

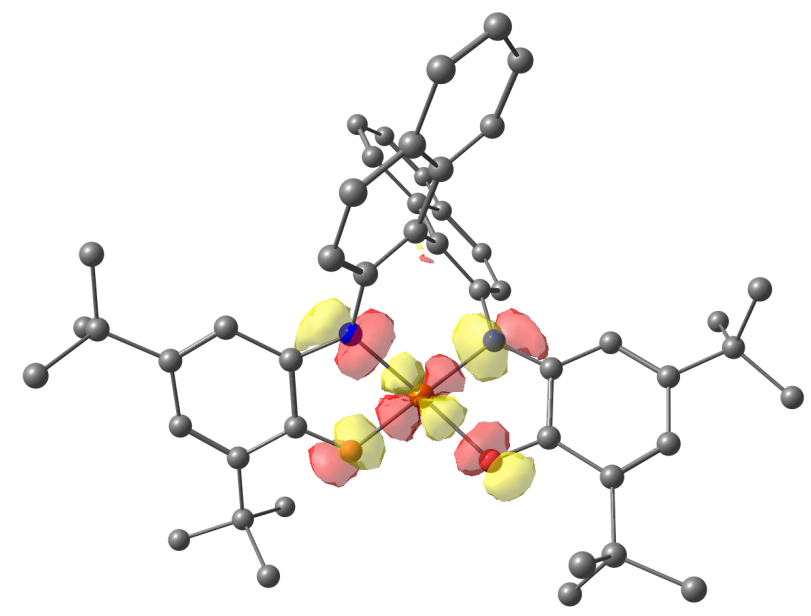

Figure SI-34: Localized SOMOs of $\mathbf{5}$. 


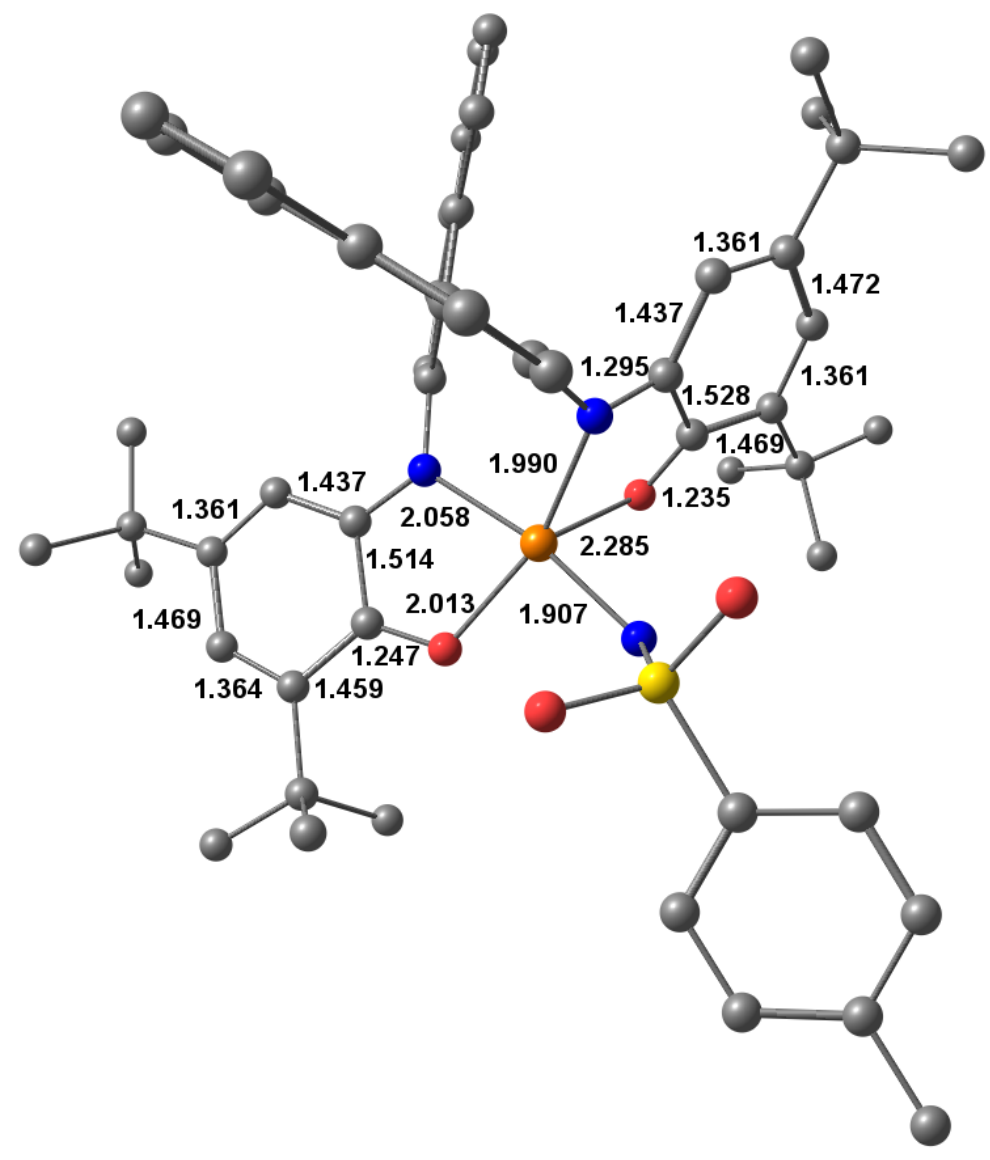

Figure SI-35: DFT-optimized structure of $\mathbf{3 6 a}$ and selected metrical parameters. Color scheme: Cu brown, $\mathrm{O}$ red, $\mathrm{N}$ blue and $\mathrm{C}$ grey. Protons were omitted for clarity.
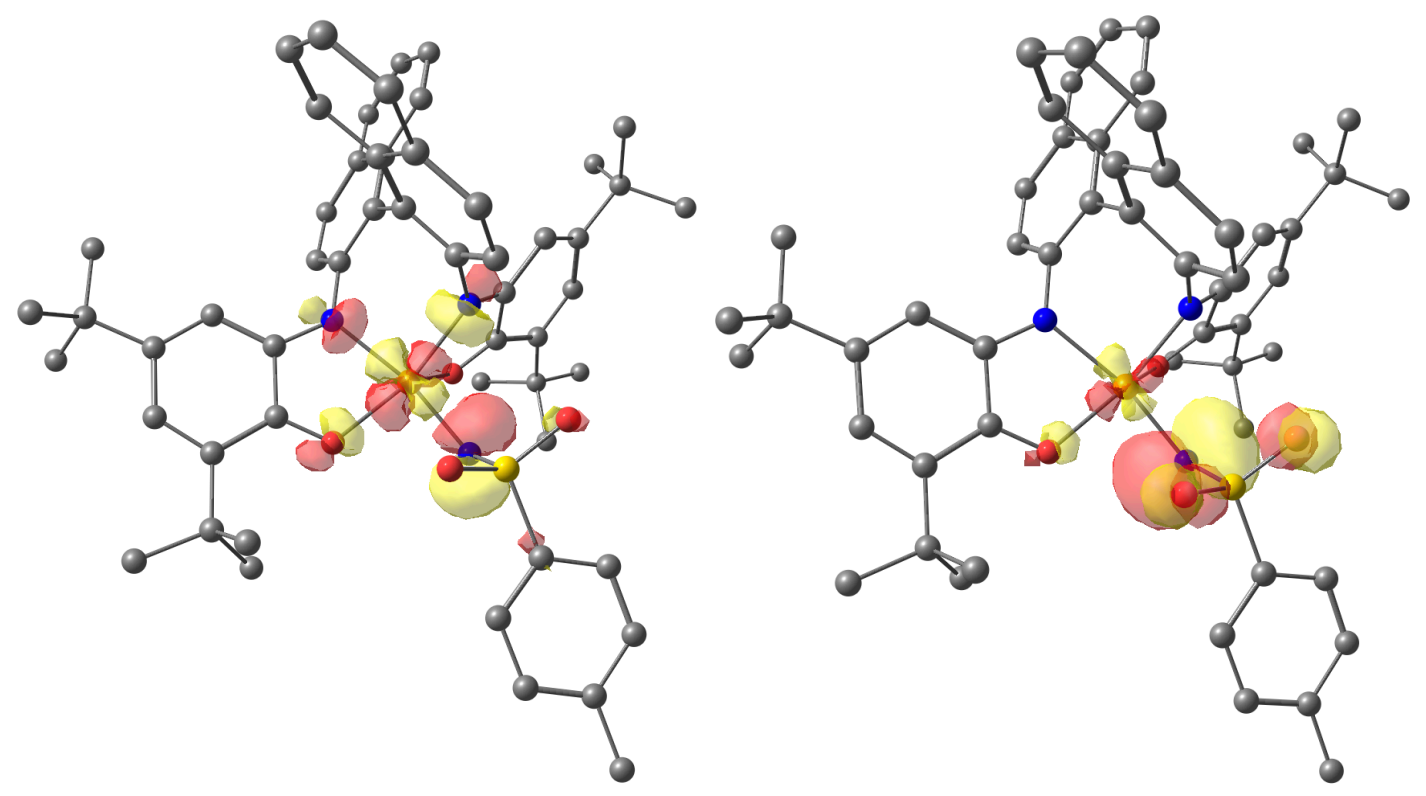

Figure SI-36: Localized SOMOs of the high-spin state of 36 a. 


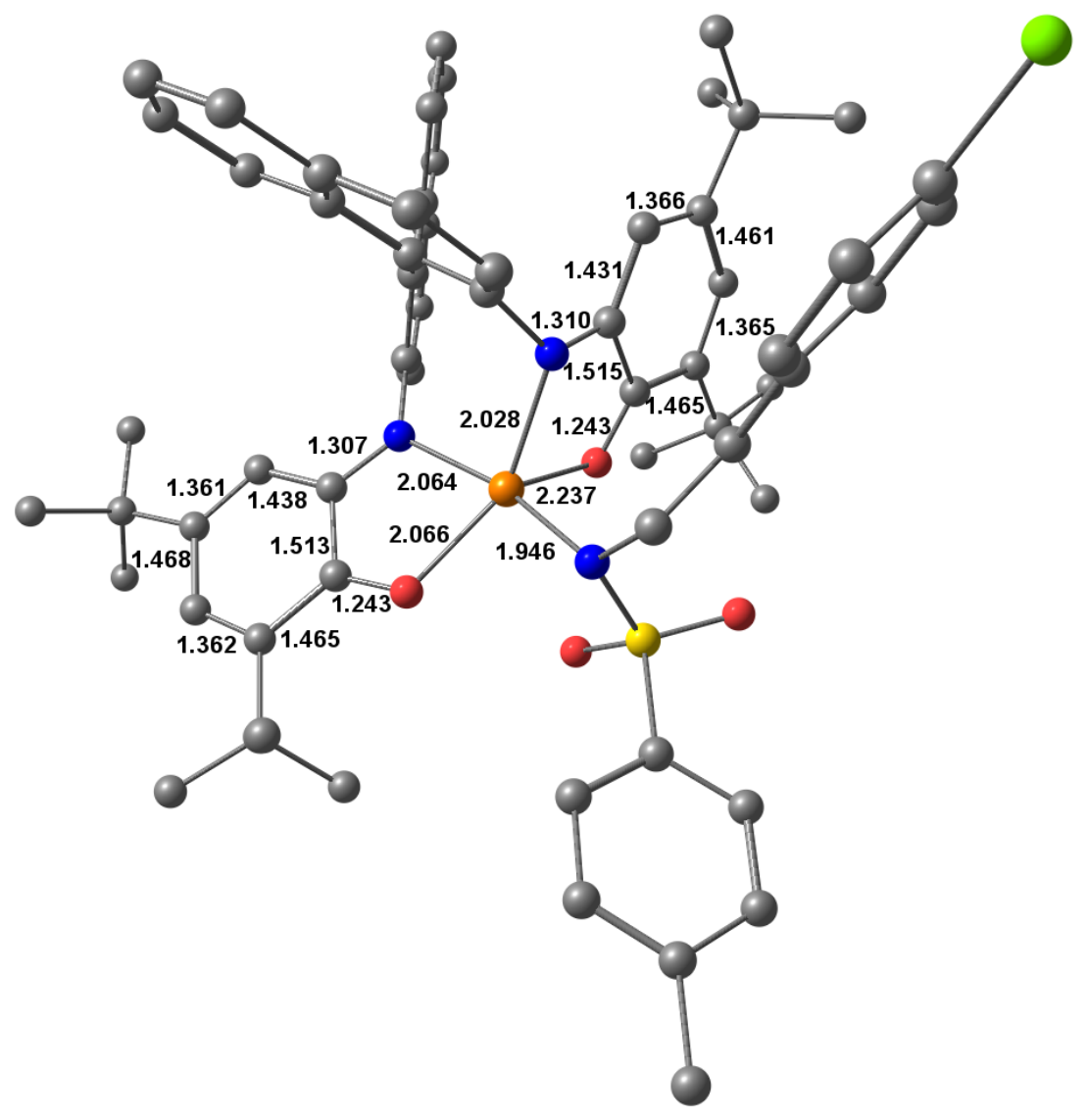

Figure SI-37: DFT-optimized structure of $37 \mathrm{a}$ and selected metrical parameters. Color scheme: Cu brown, O red, $\mathrm{N}$ blue and $\mathrm{C}$ grey. Protons were omitted for clarity.

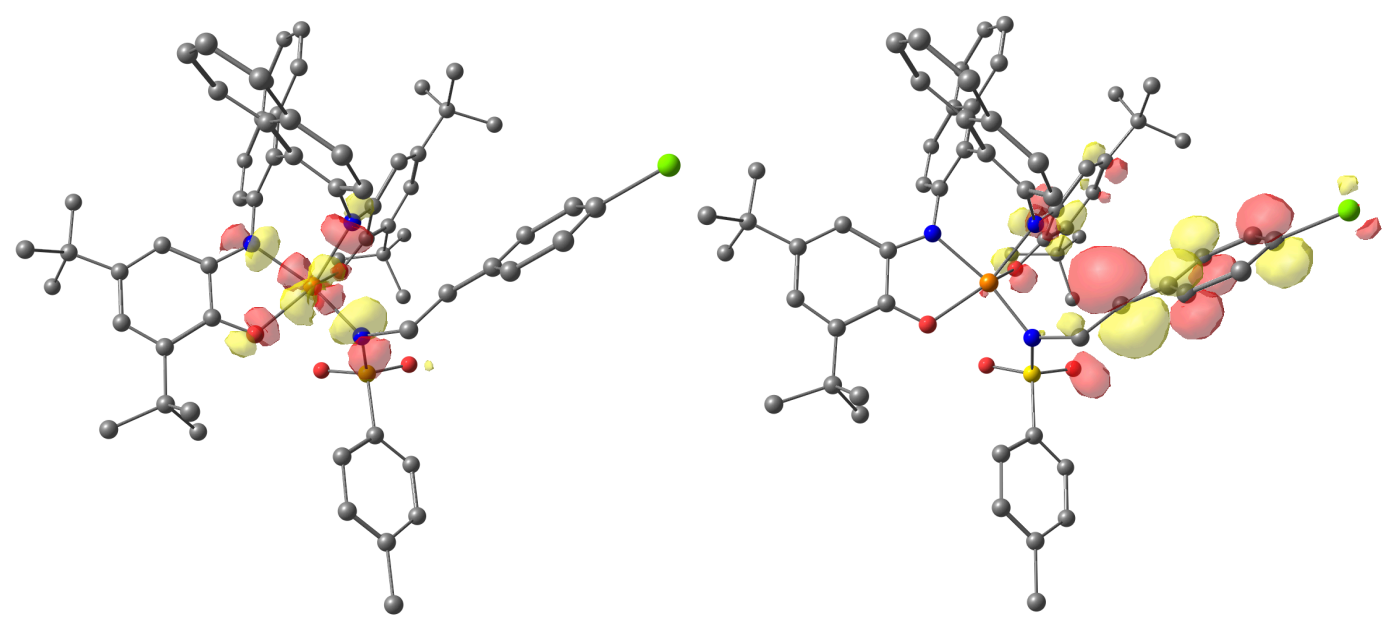

Figure SI-38: Localized SOMOs of the high-spin state of $\mathbf{3 7 a}$. 


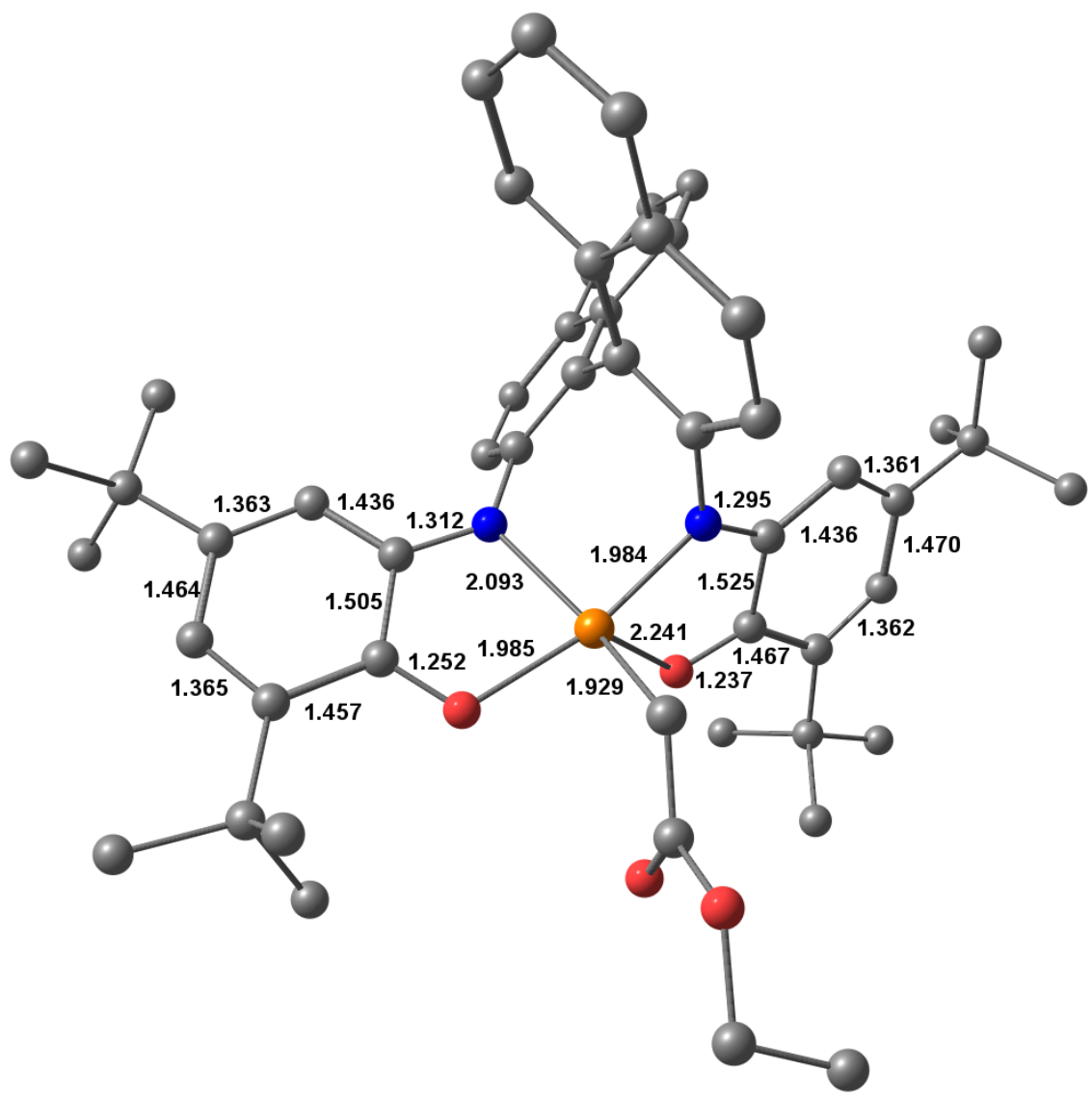

Figure SI-39: DFT-optimized structure of $\mathbf{3 6 b}$ and selected metrical parameters. Color scheme: Cu brown, $\mathrm{O}$ red, $\mathrm{N}$ blue and $\mathrm{C}$ grey. Protons were omitted for clarity.

Figure SI-40: Localized SOMOs of the high-spin state of 36b.
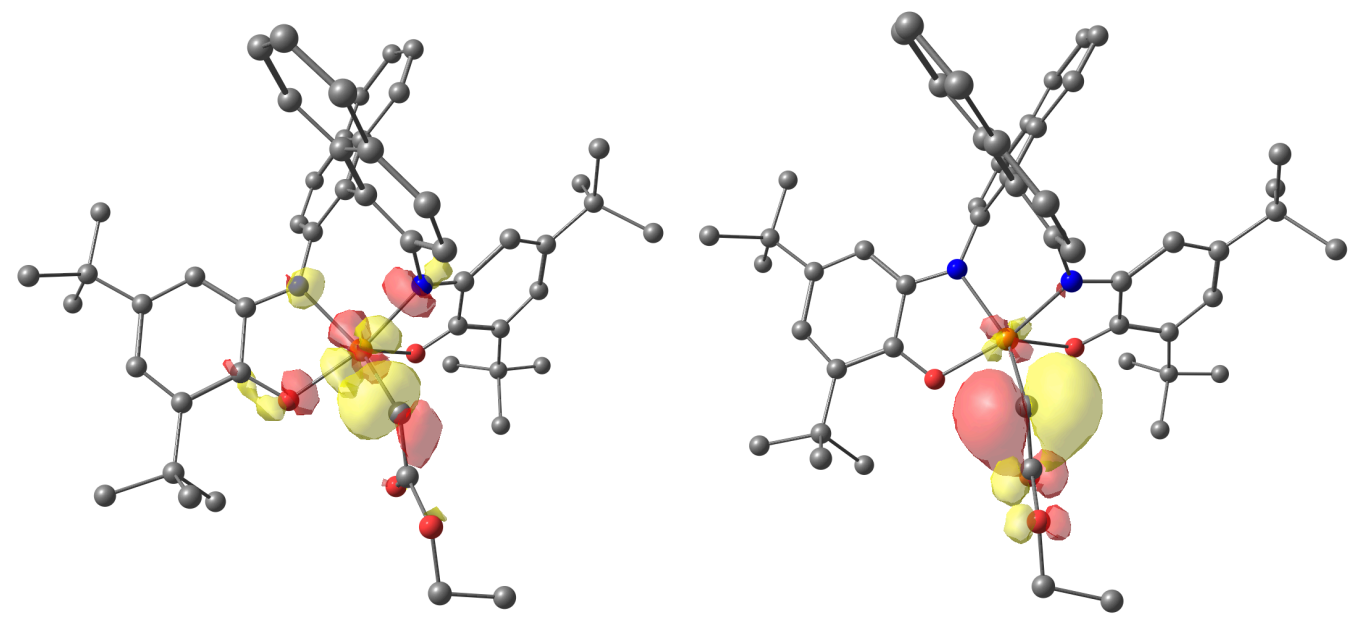


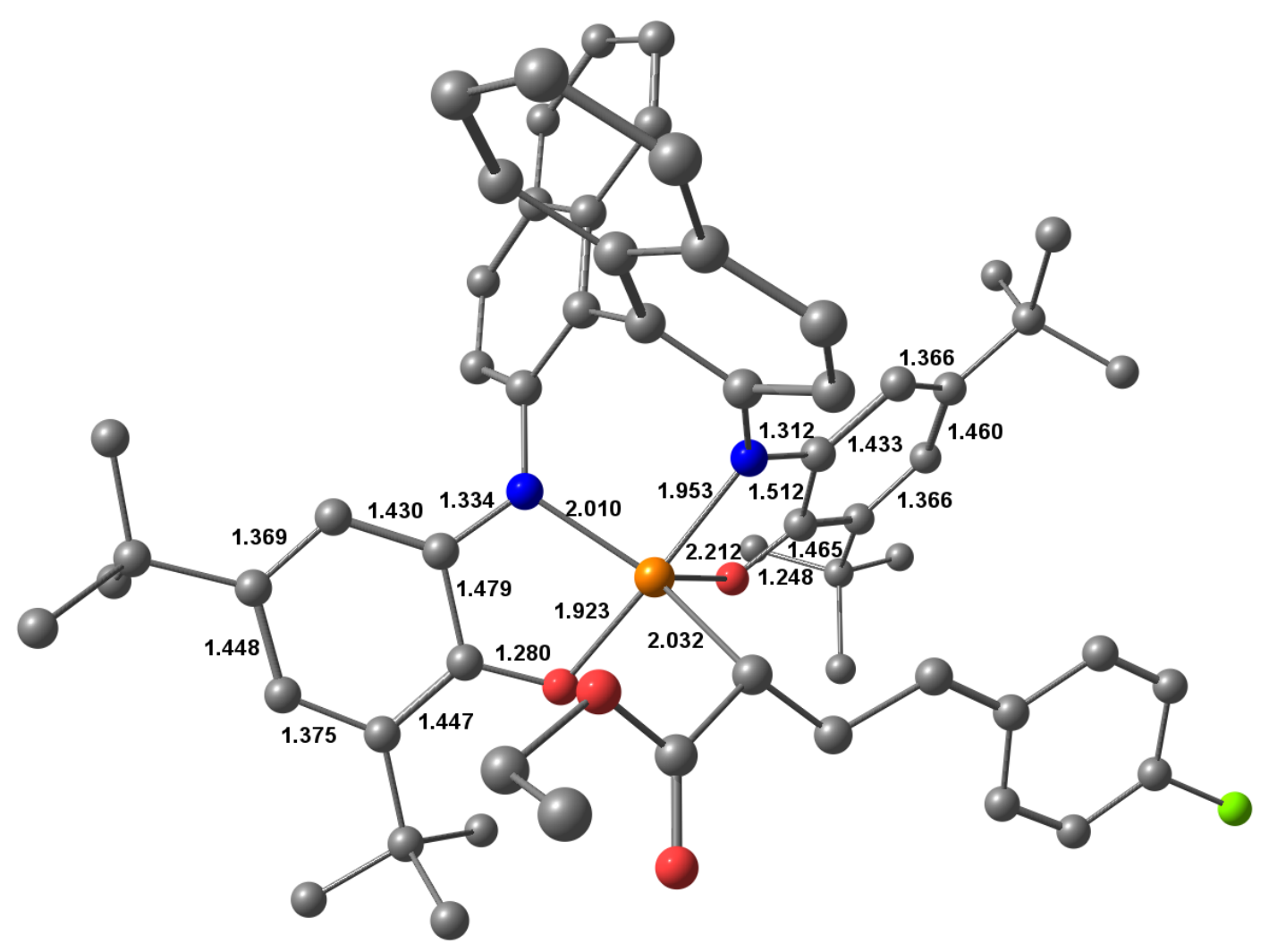

Figure SI-41: DFT-optimized structure of $\mathbf{3 7 b}$ and selected metrical parameters. Color scheme: Cu brown, O red, $\mathrm{N}$ blue and C grey. Protons were omitted for clarity.

Figure SI-42: Localized SOMOs of the high-spin state of 37b.
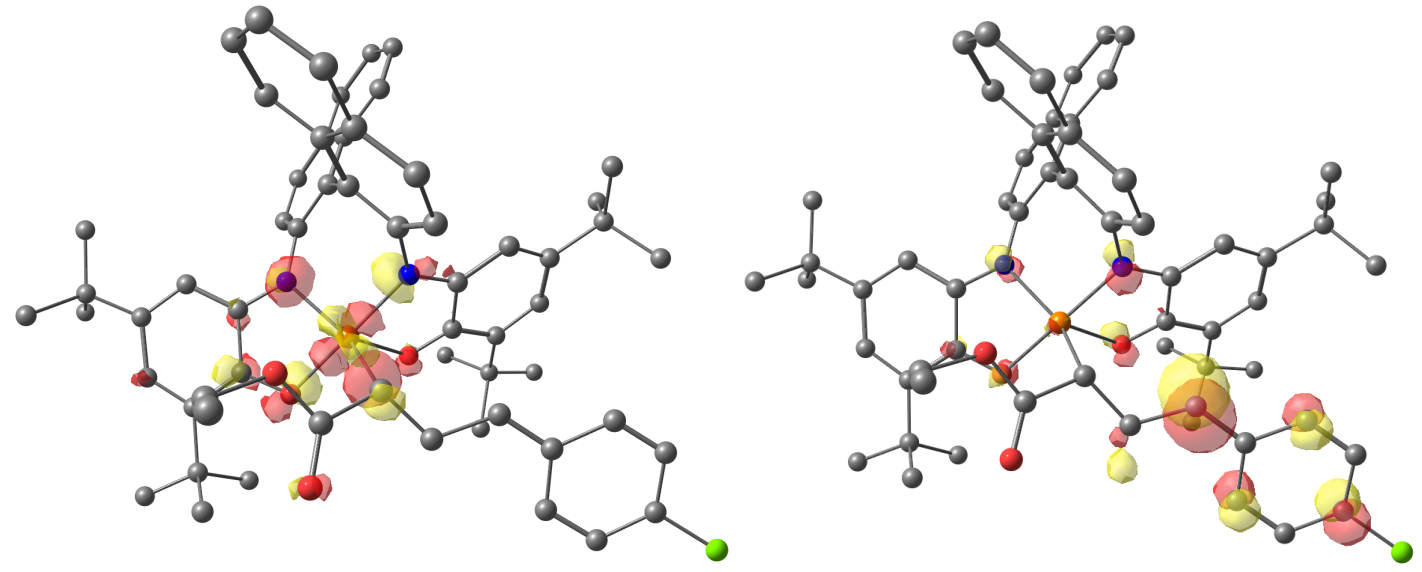
Table SI-15: DFT-calculated ground spin states (GS) and energetic separation $\left(\mathrm{cm}^{-1}\right)$ with the first excited states (ES), Boltzmann populations at $298 \mathrm{~K}$ and computed exchange coupling constants $\left(\mathrm{cm}^{-1}\right)$ of $3,1,36 a, 36 b, 37 a$ and $37 b$.

\begin{tabular}{ccccccc}
\hline Species & $\mathbf{3}$ & $\mathbf{1}$ & $\mathbf{3 6 a}$ & $\mathbf{3 7 a}$ & $\mathbf{3 6 b}$ & $\mathbf{3 7 b}$ \\
\hline $\mathrm{GS}$ & $0, \mathrm{~S}=1 / 2$ & $0, \mathrm{~S}=1$ & $0, \mathrm{~S}=1$ & $0, \mathrm{~S}=0$ & $0, \mathrm{~S}=1$ & $0, \mathrm{~S}=0$ \\
\hline ES & $258, \mathrm{~S}=3 / 2$ & $314, \mathrm{~S}=0$ & $1116, \mathrm{~S}=0$ & $124, \mathrm{~S}=1$ & $1642, \mathrm{~S}=0$ & $6, \mathrm{~S}=1$ \\
\hline Boltzmann & $78 \% \mathrm{~S}=1 / 2$ & $79 \% \mathrm{~S}=1$ & $99 \% \mathrm{~S}=1$ & $65 \% \mathrm{~S}=0$ & $99 \% \mathrm{~S}=1$ & $51 \% \mathrm{~S}=0$ \\
populations & $22 \% \mathrm{~S}=3 / 2$ & $21 \% \mathrm{~S}=0$ & $1 \% \mathrm{~S}=0$ & $35 \% \mathrm{~S}=1$ & $1 \% \mathrm{~S}=0$ & $49 \% \mathrm{~S}=1$ \\
\hline \multirow{6}{*}{$\begin{array}{c}-303 \\
\end{array}$} & & & & & & \\
& $(\mathrm{SQ}-\mathrm{SQ})$ & & & & & \\
& +332 & +140 & +958 & -62 & +821 & -3 \\
& $(\mathrm{Cu}-\mathrm{SQ})$ & $(\mathrm{Cu}-\mathrm{SQ})$ & $(\mathrm{Cu}-\mathrm{NTs})$ & $(\mathrm{Cu}-\mathrm{Styr})$ & $(\mathrm{Cu}-\mathrm{Carb})$ & $(\mathrm{Cu}-\mathrm{Styr})$ \\
& +366 & & & & & \\
& $(\mathrm{Cu}-\mathrm{SQ})$ & & & & & \\
\hline
\end{tabular}

Table SI-16: DFT-calculated final energies for the intermediates obtained upon nitrene insertion on complexes $\mathbf{4}$ and $\mathbf{1}$.

\begin{tabular}{cccc}
\hline Species & $\mathrm{E}(\mathrm{Eh})$ & $\Delta \mathrm{E}(\mathrm{Eh})$ & $\Delta \mathrm{E}(\mathrm{kcal} / \mathrm{mol})$ \\
\hline Nitrene & -874.0129 & - & - \\
\hline $\mathbf{4}$ & -3453.9334 & - & - \\
\hline $\mathbf{4}+$ nitrene & -4327.9463 & +0.0702 & +44.1 \\
\hline Adduct 4-nitrene & -4328.0165 & 0 & 0 \\
\hline $\mathbf{1}$ & -3759.7575 & - & +46.6 \\
\hline $\mathbf{1}+$ nitrene & -4633.7704 & +0.0742 & 0 \\
\hline Adduct 1-nitrene, 36a & -4633.8446 & 0 & \\
\hline
\end{tabular}


Table SI-17: DFT-calculated final energies for the intermediates obtained upon alkene insertion on nitrene intermediates obtained from complexes $\mathbf{4}$ and $\mathbf{1}$.

\begin{tabular}{cccc}
\hline Species & $\mathrm{E}(\mathrm{Eh})$ & $\Delta \mathrm{E}(\mathrm{Eh})$ & $\Delta \mathrm{E}(\mathrm{kcal} / \mathrm{mol})$ \\
\hline Nitrene-alkene & 1643.2177 & - & - \\
\hline $\mathbf{4}$ & -3453.9334 & - & - \\
\hline $\mathbf{4}+$ nitrène-alkene & -5097.1511 & +0.0002 & +0.1 \\
\hline Adduct 4-nitrene-alkene & -5097.1513 & 0 & 0 \\
\hline $\mathbf{1}$ & -3759.7575 & - & - \\
\hline 1 + nitrène-alkene & -5402.9752 & +0.0115 & +7.2 \\
\hline Adduct 1-nitrene alkene, $\mathbf{3 7 a}$ & -5402.9867 & 0 & 0 \\
\hline
\end{tabular}


